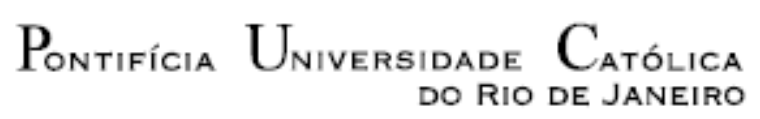

Lilia Olaya Luengas

\title{
Simulação Física e Caracterização Microestrutural e Mecânica da Zona Termicamente Afetada (ZTA) em Aços Inoxidáveis Duplex
}

Tese de Doutorado

Tese apresentada como requisito parcial para obtenção do grau de Doutor pelo Programa de Pósgraduação em Engenharia de Materiais e de Processos Químicos e Metalúrgicos do Departamento de Engenharia Química e de Materiais do Centro Técnico Científico da PUC-Rio.

Orientador: Prof. Ivani de Souza Bott

Rio de Janeiro

Setembro de 2017 
Pontifícia Universidade Católica $_{\text {d }}$

DO RIO DE JANEIRO

\section{Lilia Olaya Luengas}

\section{Simulação Física e Caracterização Microestrutural e Mecânica da Zona Termicamente Afetada (ZTA) em Aços Inoxidáveis Duplex}

Tese apresentada como requisito parcial para obtenção do grau de Doutor pelo Programa de Pós-graduação em Engenharia de Materiais e de Processos Químicos e Metalúrgicos da PUC-Rio. Aprovada pela Comissão Examinadora abaixo assinada.

Profa. Ivani de Souza Bott Orientadora

Departamento de Engenharia Química e de Materiais - PUC-Rio

Prof. Luís Felipe Guimarães de Souza CEFET/RJ

Prof. Paulo Rangel Rios Universidade Federal Fluminense - UFF

Prof. Jorge Carlos Ferreira Jorge CEFET/RJ

Dr. Marcos Henrique de Pinho Maurício Departamento de Engenharia Química e de Materiais - PUC-Rio

Prof. Márcio da Silveira Carvalho Coordenador Setorial do Centro Técnico Científico - PUC-Rio 
Todos os direitos reservados. É proibida a reprodução total ou parcial do trabalho sem autorização da universidade, do autor e do orientador.

\section{Lilia Olaya Luengas}

Gradou-se em Engenharia Metalúrgica na Universidad Industrial de Santander (Bucaramanga - Colômbia) em 2001, e mestrado em Ciências em Engenharia Mecânica na University of Puerto Rico (Mayagüez - Puerto Rico) em 2009.

Iniciou seu Doutorado na Pontifícia Universidade Católica do Rio de Janeiro em 2013, no Departamento de Engenharia Química e de Materiais e seguidamente Doutorado Sanduíche na The Ohio State University no Departamento de Engenharia de Materiais.

Tem sido professora nas áreas de materiais e de engenharia na Escuela Naval de Cadetes Almirante Padilla, Universidad Santo Tomás de Aquino e Universidad Tecnológica de Bolívar na Colômbia. As áreas de atual interesse são ciência dos materiais, microcaraterização de materiais e aços inoxidáveis duplex.

Ficha Catalográfica

Olaya Luengas, Lilia

Simulação física e caracterização microestrutural e mecânica da Zona Termicamente Afetada (ZTA) em aços inoxidáveis duplex I Lilia Olaya Luengas ; orientador: Ivani de Souza Bott. - 2017. 176 f. : il. color. ; $30 \mathrm{~cm}$

Tese (doutorado)-Pontifícia Universidade Católica do Rio de Janeiro, Departamento de Engenharia Química e de Materiais, 2017.

Inclui bibliografia

1. Engenharia de Materiais - Teses. 2. Engenharia Química Teses. 3. Aços inoxidáveis duplex. 4. Simulação física. 5. Sistema Gleeble. 6. Microcaraterização. 7. Análise digital de imagens. I. Bott, Ivani de Souza. II. Pontifícia Universidade Católica do Rio de Janeiro. Departamento de Engenharia Química e de Materiais. III. Título. 
À minha querida mãe.

Por ser exemplo de temperança, perseverança e tenacidade, e pela sua paciente espera. 


\section{Agradecimentos}

À minha mãe Lilia María, pela sua paciente espera na terra e a eterna companhia desde o céu.

A minha família, meu irmão Ramón Julian, meu pai Roque Luis, e minha amorosa tia Luz Yaneth porque sempre estão presentes apesar da distância.

Aos meus amigos e colegas Diana Carolina, Lili Edith, Ronald Beyner, María Isabel, Eliana Paola, Lorenleyn, Pamela, Patricia Isabel e Mariella por me prestar seus ombros quando mais os precisava. Amizades que cresceram e fortaleceram na PUC-Rio. Muitas vezes tenho dado graças a Deus por coloca-os em meu caminho. Galera, obrigada por tudo!

Ao meu amor Jorge Hernán, por sua companhia que me fortalece na distância, tem sido um longo caminho de mestrado e doutorado e além disso, aí ele está para mim.

À minha orientadora Professora Ivani de Souza Bott pela orientação e a grande contribuição para o desenvolvimento deste trabalho, e a sua confiança depositada em mim durante a minha formação de doutorado. A gratidão que tenho é imensurável.

A todos os professores que eu tive o privilégio de ser aluna.

Ao senhor Paulo Sergio Lima Mota da oficina do Instituto Tecnológico da PUC-Rio (ITUC) na unidade de São Marcelo, pelo corte e usinagem do material.

Ao Senai - RJ, a CEFET / RJ e o Labnano do CNPEM, pela sua participação durante o desenvolvimento de minha pesquisa.

À OSU (The Ohio State University) e ao Professor Antonio J. Ramírez Londoño pela oportunidade de realizar parte da experimentação da minha pesquisa em seu Laboratório de Engenharia de Soldagem no Departamento de Engenharia de Materiais.

À PUC-Rio, ao Departamento de Engenharia Química e de Materiais e à Coordenação de Aperfeiçoamento de Pessoal de Nível Superior (CAPES), pelo financiamento outorgado para a realização de meus estudos de doutorado e o programa de doutorado-sanduíche no exterior (PDSE). 


\section{Resumo}

Olaya-Luengas, Lilia; de Souza Bott, Ivani. Simulação Física e Caracterização Microestrutural e Mecânica da Zona Termicamente Afetada (ZTA) em Aços Inoxidáveis Duplex. Rio de Janeiro, 2017. 176 p. Tese de Doutorado - Departamento de Engenharia Química e de Materiais, Pontifícia Universidade Católica do Rio de Janeiro.

Os aços inoxidáveis duplex (AID) possuem uma estrutura mista de $\delta$-ferrita e $\gamma$-austenita em frações de volume aproximadamente iguais e combinam muitas das propriedades benéficas das duas fases, a ferrita fornece alta resistência mecânica e resistência à corrosão, enquanto que a austenita aumenta a ductilidade e a resistência à corrosão uniforme. Uma vantagem dos AID é a resistência à trincas de solidificação, que está associado à soldagem. Pela combinação de propriedades, esses aços são amplamente utilizados na indústria de equipamentos químicos, petróleo e gás, plantas de dessalinização, controle de poluição, usinas elétricas e, mais recentemente, em aplicações off-shore como na extração de petróleo em águas profundas. No entanto, a exposição destes aços a temperaturas elevadas entre $600^{\circ} \mathrm{C}$ e $1000^{\circ} \mathrm{C}$, que ocorre durante a soldagem por fusão resulta na precipitação de diferentes compostos, sendo os mais frequentemente encontrados a fase $\sigma$, a fase $\chi$, os nitretos de cromo e os carbonetos que reduzem tanto a resistência mecânica quanto a resistência a corrosão. Este trabalho teve como objetivo simular fisicamente as microestruturas da zona termicamente afetada (ZTA) dos AIDs UNS S32304, S32205 e S32750. De modo a obter diferentes ZTAs foi utilizado o simulador termo-mecânico Gleeble, por meio deste simulador foram aplicados vários aportes de calor que permitiram avaliar a evolução microestrutural e as propriedades mecânicas destas zonas. As temperaturas utilizadas nas simulações físicas foram determinadas por meio do software Thermo-Calc assegurando assim as faixas de transformações microestruturais. A temperatura de pico utilizada foi de $1350^{\circ} \mathrm{C}$ por 2 segundos; seguida de resfriamento em acordo com o modelo Rykalin-2D, onde um grupo de amostras sofreu resfriamento até alcançar a temperatura de $500^{\circ} \mathrm{C}$ seguido de uma têmpera em água e um outro grupo até $250^{\circ} \mathrm{C}$ seguido de uma têmpera. Este procedimento foi adotado de modo a identificar a influência dos aportes de calor e as taxas de resfriamento na frações volumétricas das fases obtidas. Foi observado um aumento da fração volumétrica da austenita, assim como um aumento do tamanho de grão da ferrita e um crescimento nos grãos da austenita, em função do aumento do aporte de calor durante as simulações físicas das ZTAs. 
Estas variações microestruturais ocasionaram o decréscimo da resistência mecânica nos três AID avaliados quando comparados ao respectivo metal de base.

\section{Palavras-chave}

Aços inoxidáveis duplex; Simulação física; Sistema Gleeble; Microcaraterização; Análise digital de imagens. 


\section{Abstract}

Olaya Luengas. Lilia; de Souza Bott, Ivani (Advisor). Physical Simulation and Characterization of Heat Affected Zone (HAZ) in Duplex Stainless Steels Rio de Janeiro, 2017. 176 p. Tese de Doutorado - Departamento de Engenharia Química e de Materiais, Pontifícia Universidade Católica do Rio de Janeiro.

The duplex stainless steels (DSS) have a structure that consist of approximately equivalent amounts of $\gamma$-austenita and $\delta$-ferrite, exhibit excellent properties combinations of both phases. DSS combine the high strength and resistance to stress corrosion cracking come from ferrite, whereas the austenite phase influences ductility and uniform corrosion resistance. The advantage of DSS is solidification cracking resistance; it is associated to welding processes. The application of DSS have being increasingly used as structural material in various industrial sectors, such as chemical, petrochemical, pulp and paper, power generation, desalination, oil and gas, for the constructions in marine and chemical industries and most recently for manufacturing components used in off-shore oil platforms for oil extraction in deep water. However, the exposure of these steels to high temperatures between $600^{\circ} \mathrm{C}$ and $1000^{\circ} \mathrm{C}$, which occurs during fusion welding results in different compounds precipitation, the most frequently encountered being the $\sigma$ phase, the $\chi$ phase, the chromium nitrides and carbides which reduce both mechanical strength and corrosion resistance. The aim of this work was to simulate physically the Heat Affected Zone (HAZ) microstructures in DSS UNS S32304, S32205 and S32750. In order to obtain different HAZ the Gleeble system was used. Several heat inputs were applied through this simulator, which allowed evaluate the microstructural evolution and the mechanical properties of these zones. The temperatures used in physical simulations were determined by Thermo-Calc Software, this supplied the microstructural transformations temperature ranges. The peak temperature used was $1350^{\circ} \mathrm{C}$ for 2 seconds; followed by cooling in accordance with the Rykalin-2D model; one sample set was cooled to $500^{\circ} \mathrm{C}$ followed by water quenching, and the second sample set was cooled to $250^{\circ} \mathrm{C}$ followed by quenching. This procedure was adopted in order to identify the effect of the final temperature on the phases volume fraction obtained. An increase in the austenite volume fraction, as well as an increase in the ferrite grain size and a widening in the austenite grains, due to the increase of the heat input during the physical simulations of the ZTAs was observed. These microstructural variations caused the tensile strength and Yield 
strength decreasing in HAZ of DSS evaluated when these zones were compared to the respective base metal.

\section{Keywords}

Duplex stainless steels; Physical simulation; Gleeble system; Microcharacterization; Digital image analysis. 


\section{Sumário}

1 Introdução 23

2 Objetivos 26

2.1. Objetivo Geral 26

2.2. Objetivos Específicos 26

3 Revisão Bibliográfica $\quad 28$

3.1. Aços Inoxidáveis $\quad 28$

3.2. Aços Inoxidáveis Duplex (AIDs) 28

3.3. Elementos de Liga $\quad 30$

3.4. Classificação dos AIDs 32

3.5. Fases Secundárias $\quad 35$

3.5.1. Fase $\sigma \quad 46$

3.5.2. Nitretos de Cromo 48

3.5.3. Austenita Secundária 52

3.5.4. Fase $\chi \quad 53$

3.5.5. Fase $R \quad 55$

3.5.6. Fase $\pi \quad 56$

3.5.7. Carbonetos 57

3.5.8. Fases Pouco Comuns $\quad 57$

3.6. Simulador Termo-Mecânico Gleeble 58

4 Materiais e Métodos $\quad 63$

4.1. Materiais 63

4.1.1. Processos de Fabricação 64

4.2. Métodos 65

4.2.1. Composição Química 65

4.2.2. Simulação do Diagrama de Fase no Software Thermo-Calc 65

4.2.3. Simulação Física da ZTA na Gleeble 65

4.2.4. Caraterização Metalográfica 77

4.2.5. Testes de Tração 79

4.2.6. Microdureza Vickers 82 
5 Resultados $\quad 84$

5.1. Análise Química $\quad 84$

5.2. Simulação no Software Thermo-Calc 85

5.3. Simulação Física na Gleeble $\quad 88$

5.4. Caraterização Metalográfica 96

5.4.1. Morfologia das Fases Primárias 98

$\begin{array}{ll}\text { 5.4.2. Contagem de Fases } & 103\end{array}$

5.4.3. Tamanho de Grão 110

5.4.4. Identificação de Nitretos 113

$\begin{array}{ll}\text { 5.5. Caraterização Mecânica } & 118\end{array}$

$\begin{array}{ll}\text { 5.6. Microdureza Vickers } & 125\end{array}$

6 Discussão 132

6.1. Influência da Composição Química dos Aços nas Fases que Podem se

$\begin{array}{ll}\text { Formar } & 132\end{array}$

6.2. Efeito da Composição Química na Simulação no Software Thermo-Calc 133

6.3. Efeito do Overshooting na Morfologia das ZTAs Simuladas 136

6.4. Caraterização Metalográfica 140

6.5. Efeito da Taxa de Resfriamento no Tamanho de Grão da Ferrita 141

6.6. Efeito da Taxa de Resfriamento na Fração Volumétrica da Austenita nas $\begin{array}{ll}\text { ZTAs Simuladas } & 146\end{array}$

6.7. Efeito da Fração Volumétrica da Austenita na Caracterização Mecânica 149

6.8. Efeito da Taxa de Resfriamento na Microdureza 151

7 Conclusões 156

7.1. Sugestões para Trabalhos Futuros 162

8 Referências bibliográficas 163

$\begin{array}{ll}\text { Apêndice } & 171\end{array}$ 


\section{Lista de figuras}

Figura 3-1. Diagrama de fases $\mathrm{Fe}-\mathrm{Cr}-\mathrm{Ni}$ em $70 \% \mathrm{Fe}$ mostrando a solidificação da ferrita em AIDs típicos ${ }^{38}$.

Figura 3-2. Seção de Fe constante do diagrama de fases ternário $\mathrm{Fe}-\mathrm{Cr}-\mathrm{Ni}$ com $60 \% \mathrm{Fe}^{40}$.

Figura 3-3. Predição do modo da solidificação em aços inoxidáveis usando o conceito de $\mathrm{Cr}$ e Ni equivalente ${ }^{46}$.

Figura 3-4. Seção do diagrama ternário $\mathrm{Fe}-\mathrm{Cr}-\mathrm{Ni}$ (\% em peso) com $65 \%$

em peso de $\mathrm{Fe}^{33}$.

Figura 3-5. Vista tridimensional do digrama de equilíbrio $\mathrm{Fe}-\mathrm{Cr}-\mathrm{Ni}{ }^{33}$.

Figura 3-6. Frações de fases calculadas para o SAF 2205. A fase $\sigma$ é predita a temperaturas menores do que $860^{\circ} \mathrm{C} 48$.

Figura 3-7. Fases calculadas vs temperatura do aço $2205^{49}$.

Figura 3-8. Diagrama de fase de SAF $2205^{22}$.

Figura 3-9. Diagrama de porcentagem molar de fases calculadas vs. temperatura do aço super duplex SAF $2507{ }^{49}$.

Figura 3-10. Diagramas de fase dos aços UNS S32304 (2304), UNS S32205 (2205) e UNS S32750 (2507) ${ }^{50}$.

Figura 3-11. Cinética da precipitação isotérmica das fases secundárias em AID 2205 comparada com as cinéticas dos AIDs 2304 e 250752.

Figura 3-12. Gráfico TTT mostra a precipitação da fase $\sigma$, alpha linha e outras fases em AIDs ${ }^{33}$.

Figura 3-13. Microestrutura do SAF 2507 envelhecido durante $10 \mathrm{~min}$ a $850^{\circ} \mathrm{C}$, a fase $\sigma$ aparece precipitada nos contornos de grão ferrita / ferrita e nos contornos de grão austenita / austenita, a austenita secundária é visível com contraste brilhante entre a austenita primaria e a ferrita (MEV) ${ }^{17}$.

Figura 3-14. Imagem por MET de $\mathrm{Cr}_{2} \mathrm{~N}$ intragranular e austenita secundária formadas no SAF 2507 após tratamento de envelhecimento durante 10 minutos a $850^{\circ} \mathrm{C}{ }^{17}$.

Figura 3-15. Imagem por MET de $\mathrm{Cr}_{2} \mathrm{~N}$ intergranular e a austenita secundária formados em SAF 2507 após envelhecimento durante $10 \mathrm{~min}$ a $850^{\circ} \mathrm{C}{ }^{17}$.

Figura 3-16. Imagem por MET de (a) $\mathrm{Cr}_{2} \mathrm{~N}$ (hexagonal) e (c) $\mathrm{CrN}$ (cúbico); com os correspondentes padrões de difração e índices dos planos: (b) $\mathrm{Cr}_{2} \mathrm{~N} \mathrm{e}$ (d) $\mathrm{CrN}^{9}$. 
Figura 3-17. Imagem por TEM de ZTA do aço 2205. (a) Precipitado de $\mathrm{Cr}_{2} \mathrm{~N}$ e padrão de difração (b) Pequenos precipitados em plaquinhas de $\mathrm{CrN}$ em padrão de difração (c) $\mathrm{CrN}$ e $\mathrm{Cr}_{2} \mathrm{~N} \operatorname{com} \Delta t_{8 / 5}=20 \mathrm{~s}$ e morfologia da matriz $\operatorname{com} \Delta t_{8 / 5}=120 \mathrm{~s}^{59}$.

Figura 3-18. Imagem por MEV do SAF 2507 envelhecido durante 72 horas a $700^{\circ} \mathrm{C}$ mostrando a decomposição da ferrita dentro da estrutura eutectóide de fase $\sigma$ e austenita secundária ${ }^{17}$.

Figura 3-19. Gráfico TTT para vários precipitados no aço SAF $2507{ }^{17}$.

Figura 3-20. Micrografia de BSE da superfície polida de aço SAF 2507 envelhecido por $10 \mathrm{~min}$ a $850^{\circ} \mathrm{C}$, que mostra o contraste do número atômico: As partículas em contraste brilhante são a fase $\chi$, e as partículas com contraste mais escuro são a fase $\sigma^{17}$.

Figura 3-21. Imagem por MET do MS 22Cr-8Ni-3Mo envelhecido por 24 horas a $600^{\circ} \mathrm{C}$. Os precipitados da fase $R$ apresentam contraste desigual e a relação de orientação com os grãos ferríticos é $<0001>R$ II <111> $\delta$ como amostrado no padrão de difração ${ }^{17}$.

Figura 3-22. Imagem por TEM da fase $R$ precipitada dentro da fase ferrítica do aço super duplex após do tratamento térmico de envelhecimento e solubilização. (a) Imagem de campo claro e (b) padrão de difração e índice do plano (241) 60.

Figura 3-23. Imagem por MET do 22Cr-8Ni-3Mo, envelhecido por 24 horas a $600^{\circ} \mathrm{C}$ mostrando a fase $\pi$ com contraste homogêneo no grão de ferrita.

A relação de orientação é $<001>\pi \|<012>\delta 17$.

Figura 3-24. Simulação da ZTA em uma solda de arco com o fluxo de corrente eléctrica e o fluxo de calor ${ }^{62}$.

Figura 3-25. Vista superior da unidade de simulação do equipamento Gleeble 1500 com a câmara de vácuo.

Figura 3-26. Detalhe da montagem do corpo de prova na unidade de simulação do equipamento Gleeble 1500.

Figura 3-27. Ciclo térmico de ferritização simulado aplicado por (a) Kuroda e por (b) Garzón.

Figura 4-1. Seleção do tipo de curva e propriedades dos AIDs no HAZ Software ${ }^{74}$.

Figura 4-2. Entrada de dados para gerar as curvas da simulação das ZTAs com o modelo de Rykalin-2D ${ }^{74}$.

Figura 4-3. Unidade da têmpera na Gleeble. 
Figura 4-4. Geometrias dos corpos de prova com free span de (a) $10 \mathrm{~mm}$ e (b) $20 \mathrm{~mm}$.

Figura 4-5. Corpo de prova com os dois termopares soldados acoplado às garras de cobre e porcas de aço inoxidável.

Figura 4-6. Corpo de prova de $20 \mathrm{~mm}$ de free span com os dois termopares soldados e acoplado na câmara da Gleeble.

Figura 4-7. Ciclos térmicos programados no HAZ Software em ambiente Gleeble. (a) Primeiro grupo de corpos e prova com têmpera em água a $500^{\circ} \mathrm{C}$. (b) Segundo grupo de corpos de prova com têmpera a $250^{\circ} \mathrm{C}$.

Figura 4-8. Corpo de prova de geometria reduzida segundo a norma ASTM E8/E8M-16 ${ }^{95}$.

Figura 4-9. Imagem do corpo de prova de $20 \mathrm{~mm}$ de free span com o pescoço usinado de $3 \mathrm{~mm}$ de diâmetro.

Figura 4-10. Acessório de cabeças roscadas para usar nos corpos de prova da Gleeble, dimensões em mm (desenhado pelo Professor Juan Alberto Pozo).

Figura 5-1. Frações de fase previstas para o aço inoxidável lean duplex UNS S32304 (2304).

Figura 5-2. Frações de fase previstas para o aço inoxidável duplex UNS S32205 (2205).

Figura 5-3. Frações de fase previstas para o aço inoxidável duplex UNS S32750 (2507).

Figura 5-4. As nove curvas da simulações das ZTAs executadas no aço UNS S32304 (2304).

Figura 5-5. As nove curvas da simulações das ZTAs executadas no aço UNS S32205 (2205).

Figura 5-6. As nove curvas da simulações das ZTAs executadas no aço UNS S32750 (2507).

Figura 5-7. Micrografias do aço inoxidável lean duplex 2304 na condição de como-recebido com os dois tipos de ataque.

Figura 5-8. Micrografia do aço inoxidável lean duplex 2304. Superfície atacada quimicamente com solução Beraha modificada.

Figura 5-9. Micrografia do aço inoxidável lean duplex 2304. Superfície atacada quimicamente com solução Beraha modificada. 
Figura 5-10. Micrografias do aço inoxidável lean duplex UNS S32304 na condição de como-recebido e das ZTAs simuladas com diferentes parâmetros de aporte de calor e têmpera.

Figura 5-11. Micrografias do aço inoxidável duplex UNS S32205 na condição de como-recebido e das ZTAs simuladas com diferentes parâmetros de aporte de calor e têmpera.

Figura 5-12. Micrografias do aço inoxidável super duplex UNS S32507 na condição de como-recebido e das ZTAs simuladas com diferentes parâmetros de aporte de calor e têmpera.

Figura 5-13. Micrografia típica do aço inoxidável lean duplex UNS S32304 na condição como-recebido com a superfície atacada quimicamente com solução Beraha modificada, capturada com aumento de 200X utilizada para a contagem de fases.

Figura 5-14. Exemplo de processamento e identificação da fases no aço inoxidável lean duplex UNS S32304.

Figura 5-15. Evolução da fração volumétrica da austenita e ferrita vs o aporte de calor fornecido durante a simulação da ZTA e com têmpera em água a $500^{\circ} \mathrm{C}$ no aço inoxidável lean duplex UNS S32304, superfície atacada com solução Beraha modificada.

Figura 5-16. Evolução da fração folumétrica da austenita e ferrita vs o aporte de calor fornecido durante a simulação da ZTA e com têmpera a $250^{\circ} \mathrm{C}$ no aço inoxidável lean duplex UNS S32304, superfície atacada com solução Beraha modificada.

Figura 5-17. Evolução da fração volumétrica da austenita e ferrita vs o aporte de calor fornecido durante a simulação da ZTA e com têmpera em água a $500^{\circ} \mathrm{C}$ no aço inoxidável duplex UNS S32205, superfície atacada com solução Beraha modificada.

Figura 5-18. Evolução da fração volumétrica da austenita e ferrita vs o aporte de calor fornecido durante a simulação da ZTA e com têmpera a $250^{\circ} \mathrm{C}$ no aço inoxidável duplex UNS S32205, superfície atacada com solução Beraha modificada.

Figura 5-19. Evolução da fração volumétrica da austenita e ferrita vs o aporte de calor fornecido durante a simulação da ZTA e com têmpera em água a $500^{\circ} \mathrm{C}$ no aço inoxidável super duplex UNS S32750, superfície atacada com solução Beraha modificada. 
Figura 5-20. Evolução da fração volumétrica da austenita e ferrita vs o aporte de calor fornecido durante a simulação da ZTA e com têmpera a $250^{\circ} \mathrm{C}$ no aço inoxidável super duplex UNS S32750, superfície atacada com solução Beraha modificada.

Figura 5-21. Tamanho de grão da ferrita nas ZTAs simuladas no aço lean duplex UNS S32304.

Figura 5-22. Tamanho de grão da ferrita nas ZTAs simuladas no aço duplex UNS S32205.

Figura 5-23. Tamanho de grão da ferrita nas ZTAs simuladas no aço super duplex UNS S32750.

Figura 5-24. Micrografias em campo claro e DIC com aumento de 1000X do aço inoxidável lean duplex UNS S32304 com ataque eletrolítico com $\mathrm{HNO}_{3}$ em duas etapas.

Figura 5-25. Micrografias em campo claro e DIC com aumento de 1000X do aço inoxidável duplex UNS S32205 com ataque eletrolítico com $\mathrm{HNO}_{3}$ em duas etapas.

Figura 5-26. Micrografias em campo claro e DIC com aumento de 1000X do aço inoxidável super duplex UNS $\mathrm{S} 32750$ com ataque eletrolítico com $\mathrm{HNO}_{3}$ em duas etapas.

Figura 5-27. Micrografia DIC da ZTA simulada com aporte de calor de 1,0 $\mathrm{kJ} / \mathrm{mm}$ e têmpera a $250^{\circ} \mathrm{C}$ no aço duplex UNS S32205. Superfície atacada eletrolíticamente com solução de $\mathrm{HNO}_{3}$.

Figura 5-28. Curvas Tensão-Deformação de engenharia dos três aços em estudo na condição de como-recebido, testado nos corpos de prova de geometria: Reduzida e Gleeble.

Figura 5-29. Curvas Tensão-Deformação de engenharia das ZTAs simuladas nos três aços em estudo com aportes de calor de 1,5, 2, 0 2,5 e $3,0 \mathrm{~kJ} / \mathrm{mm}$.

Figura 5-30. Propriedades mecânicas do aços na condição de comorecebido testados nos corpos de prova de geometria reduzida.

Figura 5-31. Limite de escoamento e Limite de resistência dos aços na condição de como-recebido e das ZTAs simuladas testados nos copos de prova de geometria da Gleeble.

Figura 5-32. Imagens por MEV com elétrons secundários da fratura da ZTA simulada com aporte de calor de $1,5 \mathrm{~kJ} / \mathrm{mm}$ e têmpera em água a $500^{\circ} \mathrm{C}$ no aço duplex UNS S32205. 
Figura 5-33. Microdureza HV1 dos AIDs e das ZTAs simuladas com aportes de calor de 1,0 e $3,0 \mathrm{~kJ} / \mathrm{mm}$ com têmpera a $250^{\circ} \mathrm{C}$.

Figura 5-34. Micrografias de indentação HV01 no aço lean duplex UNS S32304.

Figura 5-35. Microdureza HV0.01 das fases dos aços AIDs na condição de como-recebido.

Figura 5-36. Micrografias das indentações HV0.01 nas fases austenita e ferrita do aço lean duplex UNS S32304 na condição de como-recebido.

Figura 5-37. Microdurezas HV0.01 das ZTAs simuladas do aço lean duplex UNS S32304.

Figura 5-38. Microdurezas HV0.01 das ZTAs simuladas do aço lean duplex UNS S32205.

Figura 5-39. Microdurezas HV0.01 das ZTAs simuladas do aço super duplex UNS S32750.

Figura 5-40. Micrografias das indentações HV0.01 nas fases austenítica e ferrítica na ZTA simulada com aporte de calor de $1,0 \mathrm{~kJ} / \mathrm{mm}$ do aço lean duplex UNS S32304.

Figura 5-41. Micrografias das indentações HV0.01 nas fases austenítica e ferrítica na ZTA simulada com aporte de calor de $3,0 \mathrm{~kJ} / \mathrm{mm}$ do aço lean duplex UNS S32304.

Figura 6-1. Micrografia da ZTA simulada com $1,0 \mathrm{~kJ} / \mathrm{mm}$ com têmpera a $250^{\circ} \mathrm{C}$ no aço inoxidável lean duplex UNS S32304.

Figura 6-2. Direção de laminação da ZTA simulada com $1,0 \mathrm{~kJ} / \mathrm{mm}$ com têmpera a $250^{\circ} \mathrm{C}$ no aço inoxidável super duplex UNS S32750 com aumento de $50 \mathrm{X}$.

Figura 6-3. Relação dos tempos de resfriamento $\Delta t_{8 / 5}$ e $\Delta t_{12 / 8}$ vs aporte de calor para uma chapa de $10 \mathrm{~mm}$ de espessura.

Figura 6-4. Diagramas de aporte de calor vs tamanho de grão da ferrita durante a simulação das ZTAs no aço inoxidável lean duplex UNS S32304.

Figura 6-5. Diagramas de aporte de calor vs tamanho de grão da ferrita durante a simulação das ZTAs no aço inoxidável lean duplex UNS S32205. 143 Figura 6-6. Diagramas de aporte de calor vs tamanho de grão da ferrita durante a simulação das ZTAs no aço inoxidável lean duplex UNS S32750. 143 Figura 6-7. Limite de escoamento vs tamanho de grão de ferrita para as ZTAs simuladas nos três aços em estudo, grupo de corpos de prova com têmpera em água a $500^{\circ} \mathrm{C}$. 
Figura 6-8. Diagrama de fração volumétrica da austenita vs aporte de calor durante a simulação das ZTAs no aço inoxidável super duplex UNS S32304. 147 Figura 6-9. Diagrama de fração volumétrica da austenita vs aporte de calor durante a simulação das ZTAs no aço inoxidável duplex UNS S32205.

Figura 6-10. Diagrama de fração volumétrica da austenita vs aporte de calor durante a simulação das ZTAs no aço inoxidável super duplex UNS S32750. 148 Figura 6-11. Relação das propriedades mecânicas com a fração volumétrica da austenita no aço inoxidável lean duplex UNS S32304.

Figura 6-12. Relação das propriedades mecânicas com a fração volumétrica da austenita no aço inoxidável duplex UNS S32205.

Figura 6-13. Relação das propriedades mecânicas com a fração volumétrica da austenita no aço inoxidável super duplex UNS S32750.

Figura 6-14. Relação entre microdureza [HV1], fração volumétrica de austenita e aporte de calor no aço inoxidável lean duplex UNS S32304.

Figura 6-15. Relação entre microdureza [HV1], fração volumétrica de austenita e aporte de calor no aço inoxidável duplex UNS S32205.

Figura 6-16. Relação entre microdureza [HV1], fração volumétrica de austenita e aporte de calor no aço inoxidável super duplex UNS S32750.

Figura 6-17. Microdurezas das fases austenítica e ferrítica no aço lean duplex UNS S32304.

Figura 6-18. Microdurezas das fases austenítica e ferrítica no aço duplex UNS S32205.

Figura 6-19. Microdurezas das fases austenítica e ferrítica no aço super duplex UNS S32750. 


\section{Lista de tabelas}

Tabela 3-1. Composições nominais dos AIDs de primeira e segunda geração. 32

Tabela 3-2. Composição química (\% em peso) dos AIDs forjados mais

comuns ${ }^{17}$. 34

Tabela 3-3. Fases observadas nos aços inoxidáveis duplex 172153 32* . 46

Tabela 4-1. Composição química dos aços estudados, segundo a norma ASTM A240-15 ${ }^{69}$, porcentagem em massa (\%).

Tabela 4-2. Composição química dos aços estudados, segundo as folhas de dados da Aperam e Sandvik, porcentagem em massa (\%).

Tabela 4-3. Tratamentos térmicos dos tubos S32205 e S32750 durante o processo de fabricação de acordo com a norma ASTM A790 68.

Tabela 4-4. Tempos de resfriamento para os aportes de calor estudados.

Tabela 4-5. As 9 curvas programadas para a simulação das ZTAs na Gleeble. 73

Tabela 4-6. Primeiro grupo de corpos de prova com 4 aportes de calor e têmpera com água a $500^{\circ} \mathrm{C}$.

Tabela 4-7. Segundo grupo de corpos de prova com 4 aportes de calor e têmpera a $250^{\circ} \mathrm{C}$.

Tabela 4-8. Especificações da propriedades mecânicas dos AIDs em estudo segundo a ASTM A240-15 ${ }^{69}$.

Tabela 4-9. Quantidade de corpos de prova testados por tração.

Tabela 4-10. Especificações da dureza máxima dos AIDs em estudo, seguindo a *ASTM A240-15 ${ }^{69} \mathrm{e}$ **ASTM E140-12 ${ }^{97}$.

Tabela 5-1. Composição química dos aços estudados, analise obtida seguindo a norma ASTM A751-11 ${ }^{70}$, porcentagem em massa (\%).

Tabela 5-2. Cálculo do PREw nos AIDs.

Tabela 5-3. Temperaturas do balance de fases Austenita-Ferrita próximo 50:50 e temperatura de completa ferritização.

Tabela 5-4. Composição das fases identificadas ${ }^{72}$.

Tabela 5-5. Fração Volumétrica das fases calculadas pelo método de análise digital de imagem no aço inoxidável lean duplex UNS S32304 na condição de como-recebido, superfície atacada com solução Beraha Modificada. Erro calculado com $97,5 \%$ de IC.

Tabela 5-6. Fração Volumétrica das fases calculadas pelo método de análise digital de imagem nas ZTA simuladas com 4 aportes de calor e temperadas 
a $500^{\circ} \mathrm{C}$ no aço inoxidável lean duplex UNS S32304 na condição comorecebido. Superfície atacada com solução Beraha Modificada. Erro calculado com $97,5 \%$ de IC.

Tabela 5-7. Fração volumétrica das fases calculadas pelo método de análise digital de imagem do aço inoxidável lean duplex UNS S32304 com 5 aportes de calor e temperados a $250^{\circ} \mathrm{C}$. Erro calculado com $97,5 \%$ de IC.

Tabela 5-8. Fração volumétrica das fases calculadas pelo método de análise digital de imagem no aço inoxidável duplex UNS S32205 na condição de como-recebido, superfície atacada com solução Beraha modificada. Erro calculado com $97,5 \%$ de IC.

Tabela 5-9. Fração volumétrica das fases calculadas pelo método de análise digital de imagem nas ZTA simuladas com 4 aportes de calor e temperadas a $500^{\circ} \mathrm{C}$ do aço inoxidável duplex UNS S32205, superfície atacada com solução Beraha modificada. Erro calculado com $97,5 \%$ de IC.

Tabela 5-10. Fração volumétrica das fases calculadas pelo método de análise digital de imagem nas ZTA simuladas com 5 aportes de calor e temperadas a $250^{\circ} \mathrm{C}$ do aço inoxidável duplex UNS S32205, superfície atacada com solução Beraha modificada. Erro calculado com 97,5\% de IC. 108 Tabela 5-11. Fração volumétrica das fases calculadas pelo método de análise digital de imagem no aço inoxidável super duplex UNS S32750 na condição de como-recebido, superfície atacada com solução Beraha modificada. Erro calculado com $97,5 \%$ de IC.

Tabela 5-12. Fração volumétrica das fases calculadas pelo método de análise digital de imagem nas ZTA simuladas com 4 aportes de calor e temperadas em água a $500^{\circ} \mathrm{C}$ do aço inoxidável super duplex UNS S32750, superfície atacada com solução Beraha modificada. Erro calculado com $97,5 \%$ de IC.

Tabela 5-13. Fração volumétrica das fases calculadas pelo método de análise digital de imagem nas ZTA simuladas com 5 aportes de calor e temperadas a $250^{\circ} \mathrm{C}$ do aço inoxidável super duplex UNS S32750, superfície atacada com solução Beraha modificada. Erro calculado com $97,5 \%$ de IC.

Tabela 5-14. Aumento do tamanho de grão da ferrita pelo aumento de aporte de calor durante a simulação da ZTA.

Tabela 5-15. Quadro comparativo das micrografias DIC capturadas a 1000X, dos aços na condição de como-recebido e as ZTAs simuladas com aportes de calor de 1,0 e $3,0 \mathrm{~kJ} / \mathrm{mm}$. 
Tabela 5-16. Limites de escoamento, e Limites de resistência dos aços AIDs em estudo especificados pela norma ASTM A240-15 ${ }^{69}$ e o fabricante quanto os resultados obtidos na condição de como-recebido com os dois tipos de corpos de prova, de geometria Reduzida ${ }^{95}$ e geometria Gleeble.

Tabela 5-17. Limites de escoamento, e Limites de resistência obtidos nas ZTAs simuladas do primeiro grupo de corpos de prova nas condições de 4 aportes de calor e tempera em água a $500^{\circ} \mathrm{C}$.

Tabela 5-18. Microdurezas HV1 dos AIDs e das ZTAs simuladas com aportes de calor de 1,0 e $3,0 \mathrm{~kJ} / \mathrm{mm}$ com têmpera a $250^{\circ} \mathrm{C}$.

Tabela 5-19. Microdureza HV0.01 das fases austenita e ferrita nos aços em estudo na condição de como-recebido.

Tabela 5-20. Microdureza HV0.01 das fases nas ZTAs simuladas com aportes de calor de 1,0 e $3,0 \mathrm{~kJ} / \mathrm{mm}$.

Tabela 6-1. Composição química dos AIDs em estudo.

Tabela 6-2. Previsão da composição das fases ferrítica e austenítica ${ }^{72}$.

Tabela 6-3. Médias dos overshooting nas temperatura de pico durante as simulações das ZTAs nos aços em estudo.

Tabela 6-4. Médias dos overshooting nas temperatura de pico durante as simulações das ZTAs nos aços em estudo.

Tabela 6-5. Ângulo de Feret dos grãos de austenita das ZTAs simuladas no aço inoxidável super duplex medido desde a horizontal.

Tabela 6-6. Correlação de aportes de calor, $\Delta t_{12 / 8}$, e taxa de resfriamento com o tamanho de grão da ferrita nos aços em estudo durante a simulação das ZTAs com têmpera em água a $500^{\circ} \mathrm{C}$.

Tabela 6-7. Correlação de aportes de calor, $\Delta t_{12 / 8}$, e taxas de resfriamento com o tamanho de grão da ferrita nos aços em estudo durante a simulação das ZTAs com têmpera a $250^{\circ} \mathrm{C}$.

Tabela 6-8. Correlação de aportes de calor, $\Delta t_{12 / 8}$, e taxa de resfriamento com a fração volumétrica da austenita nos aços em estudo durante a simulação das ZTAs com têmpera em água a $500^{\circ} \mathrm{C}$.

Tabela 6-9. Correlação de aportes de calor, $\Delta t_{12 / 8}$, e taxas de resfriamento com a fração volumétrica da austenita nos aços em estudo durante a simulação das ZTAs com têmpera a $250^{\circ} \mathrm{C}$. 


\section{Lista de Abreviações e Símbolos}
AID: Aço inoxidável duplex
ZTA: Zona termicamente afetada
CST Corrosão sob tensão
MS: $\quad$ Metal de solda
MB: $\quad$ Metal base
PRE: Número equivalente da resistência à corrosão por pites
MO: $\quad$ Microscopia ótica
DIC: Microscopia diferencial de contraste de interferência
MEV: Microscopia eletrônica de varredura
MET: Microscopia eletrônica de transmissão
EDX: Espectroscopia de raios $\mathrm{X}$ por dispersão em energia
BSE: Elétrons retroespalhados
IC: Intervalo de confiança 


\section{Introdução}

Os aços inoxidáveis duplex (AIDs) fornecem combinações de propriedades que não são facilmente alcançáveis em aços inoxidáveis convencionais austeníticos ou ferríticos. O s AIDs oferecem alta tenacidade, boa soldabilidade, resistência satisfatória à corrosão, excelente resistência à fissuração por CST (corrosão sob tensão) e alta resistência mecânica ${ }^{1}$.

Nos últimos anos os AIDs vem desempenhado um papel muito importante em diferentes setores da indústria tal como, a do petróleo e gás 234 . Os aços duplex têm encontrado mais aplicações na construção e o transporte em geral ${ }^{25}$, além de outras aplicações importantes em ambientes marinhos agressivos ${ }^{6}$, como componentes das plataformas off-shore para extração de petróleo em águas profundas ${ }^{78}$, na indústria de processos e fabricação de navios de transporte de produtos químicos ${ }^{9}$ e plantas de dessalinização ${ }^{8}$. Atualmente, há uma ampla gama de graus e todos oferecem uma combinação atraente de elevada resistência mecânica e boa resistência à corrosão, graças à microestrutura bifásica que consiste aproximadamente de $50 \%$ de ferrita e $50 \%$ de austenita ${ }^{2}$. A ferrita oferece alta resistência mecânica e resistência à fissuração por CST e a austenita contribui à boa ductibilidade e a resistência à corrosão geral ${ }^{10}$.

Inicialmente, os AIDs eram raramente usados e difíceis de serem soldados. Atualmente, são considerados uma alternativa frente aos aços inoxidáveis mais utilizados no mercado.

A aplicação prática de qualquer aço em maior escala é criticamente dependente do uso dos processos de soldagem na fabricação. A produtividade é uma questão fundamental na fabricação e com o aumento do uso dos AIDs este aspecto tem-se tornado mais importante ${ }^{2}$. A soldagem é requerida na maioria das aplicações e, consequentemente, a compreensão do efeito da soldagem na integridade do componente final é essencial ${ }^{1}$.

As novas metodologias de soldagem, a produção de novos aços e a ampliação das faixas de aporte de calor tem trazido mudanças na tecnologia de soldagem. Existem muitos exemplos que incluem a soldagem de AIDs como processo de fabricação. Portanto, as especificações de parâmetros de soldagem 
precisam ser re-examinadas para que sejam amplamente aceitas e aplicadas aos graus de aços mais recentes ${ }^{2}$.

A microestrutura e as propriedades do metal de solda (MS) são geralmente controlados com sucesso devido ao ajuste da composição do material de adição. No entanto, a microestrutura da zona termicamente afetada (ZTA) é determinada pelo ciclo térmico aplicado e é muito sensível aos parâmetros de soldagem. A ZTA geralmente se desenvolve a partir de uma estrutura que consiste de uma distribuição de fases 50:50, de austenita em uma matriz ferrítica ${ }^{1}$. A tenacidade e a resistência à corrosão do MS e da ZTA são consequentemente dependentes do balanço das duas fases ${ }^{10}$.

Os processos de soldagem podem ter efeitos significativos sobre as propriedades mecânicas e a resistência à corrosão. Por exemplo, a alto percentual de ferrita no MS ou na ZTA prejudica essas propriedades. Além disso, é amplamente aceito que a presença de pequenas quantidades de fases secundárias pode ter efeitos nocivos importantes ${ }^{2}$. Na ZTA pode ocorrer a transformação de uma fase única de ferrita com crescimento do grão simultâneo, seguido pela nucleação e crescimento dos grão de austenita nas fronteiras do grão da ferrita enquanto se resfria, ou se pode produzir uma microestrutura parcialmente transformada que contém ilhas austeníticas parcialmente dissolvidas na matriz ferrítica ${ }^{1}$.

As altas velocidades de resfriamento envolvidas na formação da ZTA resultam numa matriz ferrítica supersaturada com respeito tanto aos elementos de liga substitucionais quanto aos intersticiais. Isto pode levar à precipitação de fases ricas em cromo e molibdênio durante o resfriamento a partir da temperatura de pico ou como resultado de re-aquecimentos durante os passes subsequentes ${ }^{1}$.

Embora os AIDs ofereçam uma atraente combinação de propriedades mecânicas e de resistência à corrosão, estes aços são propensos a formação de fases intermetálicas a altas temperaturas. A precipitação da fase $\sigma$ é conhecida por fragilizar e por diminuir drasticamente as propriedades de tenacidade dos AIDs. Portanto, tanto os tratamentos térmicos como as soldagens devem ser realizados com cuidado ${ }^{11}$.

Desta forma, esta tese teve como objetivo caracterizar as microestruturas das ZTAs obtidas por simulação física nos AIDs UNS S32304, S32205 e $\$ 32750$. De modo a obter diferentes ZTAs foi utilizado o simulador termo-mecânico Gleeble, e por meio deste simulador foram aplicados altos e baixos aportes de calor de modo a permitir avaliar a evolução microestrutural e as propriedades mecânicas destas regiões. As temperaturas utilizadas nas simulações físicas 
foram determinadas por meio do software Thermo-Calc assegurando assim as faixas de transformações microestruturais. A temperatura de pico utilizada foi de $1350^{\circ} \mathrm{C}$ por 2 segundos; seguida de resfriamento em acordo com o modelo Rykalin-2D. Quando um primeiro grupo de corpos de prova atingiu a temperatura de $500^{\circ} \mathrm{C}$ foi submetido a uma têmpera em água, e quando o segundo grupo atingiu a temperatura de $250^{\circ} \mathrm{C}$ foi seguido de uma têmpera. Este procedimento foi adotado de modo a identificar a influência dos aportes de calor e das taxas de resfriamento na fração volumétrica das fases obtidas.

Esta tese está organizada da seguinte forma:

- Capitulo 2: Revisão bibliográfica, que apresenta os fundamentos dos AIDs e os precipitados que podem ser achados neste tipo de aços inoxidáveis.

- Capítulo 3: Objetivos,

- Capítulo 4: Materiais e Métodos,

- Capítulo 5: Resultados,

- Capítulo 6: Discussão,

- Capítulo 7: Conclusões,

- Capitulo 8: Referências Bibliográficas. 


\section{2 \\ Objetivos}

\section{1.}

\section{Objetivo Geral}

Estudar de maneira sistemática o comportamento microestrutural e mecânico dos aços inoxidáveis duplex de diferente PRE, que se apresentam ante processos de soldagem mediante simulação física. Estes processos envolvem transformações de fases a alta temperatura e a diferentes velocidades de resfriamento. Além disso, estabelecer os melhores parâmetros de aporte de calor nas soldas que evitem a formação de fases secundárias ou proporcionem a menor quantidade delas. Os resultados permitiram estabelecer as condições tempotemperatura ótimas para cada um dos aços inoxidáveis duplex contemplados nesta pesquisa.

\section{2.}

\section{Objetivos Específicos}

- Caracterizar as propriedades microestruturais e mecânicas dos 3 aços duplex selecionados: aço lean duplex UNS S32304 (2304), duplex UNS S32205 (SAF 2205) e super duplex S32750 (SAF 2507) considerando seus processos termo-mecânicos, na condição de como-recebido.

- Determinar as fases e as frações volumétricas das fases presentes nos 3 aços duplex na condição de como-recebido por análise digital de imagem.

- Determinar as propriedades mecânicas a tração e a microdureza Vickers dos 3 aços duplex na condição como-recebido.

- Calcular a estabilidade das fases presentes nos 3 aços duplex mediante o uso do software Thermo-Calc. 
- $\quad$ Estudar as mudanças das propriedades microestruturais e mecânicas dos 3 AIDs: lean duplex UNS S32304 (2304), duplex UNS S32205 (SAF 2205) e super duplex S32750 (SAF 2705) em função da simulação física da soldagem.

- Simular na Gleeble a obtenção da ZTA com 5 diferentes aportes de calor nos 3 aços duplex selecionados.

- Determinar as fases e as frações volumétricas presentes nas ZTAs geradas pela simulação em cada uma das amostras dos 3 tipos de aços duplex.

- Avaliar as propriedades mecânicas das ZTAs simuladas mediante testes resistência à tração e de microdureza.

- Correlacionar as propriedades microestruturais e mecânicas dos aços duplex em estudo na condição de como-recebido com as propriedades obtidas nas ZTAs simuladas e determinar os parâmetros de aporte de calor para cada um dos aços duplex em estudo, de modo a definir os parâmetros de aporte de calor que proporcionem as melhores propriedades da ZTAs para cada um dos aços. 


\section{3 \\ Revisão Bibliográfica}

3.1.

Aços Inoxidáveis

Os aços inoxidáveis podem ser designados acordo as normas ASTM ${ }^{12}, \mathrm{ACl}$, SAE e AISI.

Os aços inoxidáveis estão comumente classificados em 5 grupos ${ }^{13}$ :

- Aços inoxidáveis martensíticos

- Aços inoxidáveis ferríticos

- Aços inoxidáveis austeníticos

- Aços inoxidáveis endurecidos por precipitação

- Aços inoxidáveis duplex (ferríticos-austeníticos)

A denominação UNS (Unified Numbering System) foi desenvolvido pela ASTM e a SAE para correlacionar diferentes sistemas de numeração para metais e ligas comerciais. O número UNS não é uma especificação, é um número de identificação para metais ou ligas especificadas em outra organização. A UNS estabelece mediante a norma ASTM E527-16 12, 18 series de números para metais e ligas. No caso da série S00001 a S99999, corresponde aos aços (inoxidáveis) resistentes à corrosão e o calor.

\section{2.}

\section{Aços Inoxidáveis Duplex (AIDs)}

Os AIDs existem há mais de 80 anos, desde a década de 1930. O termo duplex se refere ao grau do aço cuja estrutura recozida possui fração volumétrica tipicamente próxima de 50:50 de austenita e ferrita. Embora não seja formalmente definido, é geralmente aceito que uma destas fases se apresente em menor quantidade tipicamente de $30 \%$ em volume ${ }^{14} 15$.

Os AIDs são definidos como uma família de aços que possuem microestrutura bifásica contendo ferrita CCC e austenita CFC. A quantidade exata de cada fase é uma função da composição química e do tratamento térmico ${ }^{13} 16$. As duas fases dos AIDs são inoxidáveis, isto é, ambas contêm mais de 13\% em 
peso de Cr. Na prática, o termo duplex é reservado para as ligas em que a ferrita e a austenita estão presentes em relativamente em grandes volumes separados e em frações volumétricas aproximadamente iguais, oposto às ligas em que um dos constituintes aparece na forma de pequenos precipitados ${ }^{17}$.

Nos últimos anos, o interesse em AIDs advém da alta resistência mecânica e da resistência à corrosão induzida por cloretos, que é um problema em muitas aplicações marítimas e petroquímicas, além do menor custo quando comparado ao aço inoxidável austenítico. Quanto a soldabilidade destes aços, esta foi melhorada através da redução do teor de carbono e do aumento do teor de nitrogênio ${ }^{16} 17 .{ }^{16}$

As microestruturas dos AIDs usualmente contêm entre 5 - $40 \%$ de ferrita, dependendo do grau do aço e do teor dos elementos promotores de ferrita e austenita. O uso dos AIDs é focado principalmente nos graus CF, particularmente na indústria de geração de energia (onde a letra $C$ indica que a liga destina-se principalmente para o serviço de corrosão líquida e a letra $\mathrm{F}$ denota o tipo de liga de acordo com o teor de cromo-níquel, $10 \% \mathrm{Ni}$ e $20 \% \mathrm{Cr}$ ). O aumento da resistência mecânica dos aços graus CF está essencialmente limitado à incorporação da ferrita (acima de $40 \%$ em volume) na matriz austenítica ${ }^{13}$.

Uma combinação atraente da resistência à corrosão e das propriedades mecânicas numa faixa de temperatura de -50 a $250^{\circ} \mathrm{C}$ é oferecido pelos AIDs. Por exemplo, a resistência à fissuração por CST e à corrosão por pites é excelente e em muitos casos superior à dos aços austeníticos de custo comparável. Devido à estrutura de grão fino nos AIDs obtida por recozimento sem perda substancial da tenacidade, se originam valores de limite de escoamento que são o dobro daquela obtida para os aços inoxidáveis austeníticos. É importante enfatizar, que os AIDs são menos apropriados do que os aços austeníticos para temperaturas acima de $250^{\circ} \mathrm{C}$ e abaixo de $-50^{\circ} \mathrm{C}$ por causa do comportamento frágil da ferrita nestas temperaturas. Um fator de importância econômica é o baixo teor de níquel, normalmente de 4 a $7 \%$ em comparação com o teor de $10 \%$ ou mais dos aços inoxidáveis austeníticos, resultando no mais baixo custo do AIDs em muitas aplicações ${ }^{14} 17$.

A resistência à corrosão do AIDs é similar a dos aços inoxidáveis com teor de elementos de liga semelhantes. No entanto, os AIDs possuem maior limite de resistência e limite de escoamento e maior resistência à fissuração por CST do que a contraparte os aços inoxidáveis austeníticos devido ao balanço das duas fases. A tenacidade dos AIDs está entre a dos aços inoxidáveis austeníticos e ferríticos ${ }^{13} 10$. 
Considerando os processos de soldagem nos AIDs, ao contrário dos aços inoxidáveis austeníticos, o principal problema dos AIDs não é a fissuração a quente mais sim a perda de resistência à corrosão e/ou tenacidade. Estas alterações indesejáveis ocorrem devido a vários fatores, incluindo o alto teor de ferrita e a precipitação de nitretos na ZTA, a formação de fases secundárias intermetálicas como a fase $\sigma$, fase $\chi$ e austenita secundária, e além da perda do balanço das fases austenita e ferrita no MB e na ZTA. Por isso é necessário controlar os aportes de calor e taxas de resfriamento, o resfriamento deve ser suficientemente lento para a adequada formação de austenita e suficientemente rápido para evitar a precipitação de fases deletérias ${ }^{18}$.

\section{3.}

\section{Elementos de Liga}

Os elementos de liga mais importantes dos AIDs são cromo, molibdênio, níquel, nitrogênio, cobre, silício e tungstênio. Estes elementos são adicionados para controlar o equilíbrio estrutural e para conferir certas características de resistência à corrosão.

O cromo e o molibdênio favorecem a formação e a estabilização da ferrita, produzindo um campo ferrítico mais amplo no diagrama temperatura/composição. Por outro lado, o nitrogênio e o níquel são estabilizadores da austenita ${ }^{19}$, ampliando o campo da fase austenítica nos sistemas contendo ferro e, além disso são conhecidos por melhorar as propriedades mecânicas. Alguns graus de AIDs também contêm adições de outros elementos tais como manganês, cobre ou tungstênio 132021 . O tungstênio também atua como elemento estabilizador da ferrita 22

O cromo é um elemento muito importante para melhorar a resistência dos aços na maior parte dos diferentes tipos de corrosão. Além disso, aumenta a resistência mecânica da liga. A presença de um alto teor de cromo, implica na boa solubilidade de nitrogênio em solução sólida. É desejável portanto, manter o teor do cromo tão alto quanto possível, a fim de melhorar a resistência mecânica e resistência à corrosão ${ }^{15}$.

O molibdênio, melhora a resistência à corrosão em ambientes com cloretos, assim como na redução de ácidos ${ }^{15}$. No entanto, um elevado teor de molibdênio, em combinação com um elevado teor de cromo promovem o aumento do risco de formação de compostos intermetálicos ${ }^{15} 23$. A presença de molibdênio aumenta não só o PRE (Número equivalente da resistência à corrosão por pites), 
como também aumenta a tendência à precipitação da fase $\sigma$ e fase $\chi$ a altas temperaturas, deteriorando as propriedades ao impacto. Assim, a redução de molibdênio sem uma diminuição do PRE é muito importante 2423 .

Embora a redução dos teores de cromo e molibdênio possam desacelerar a precipitação da fase $\sigma$, também podem enfraquecer a resistências à corrosão por pites e em frestas e à fissuração por CST ${ }^{25}$.

Com a adição do níquel, a precipitação da fase $\sigma$ pode ser reduzida, mas é necessário longos períodos de envelhecimento para que o efeito seja percebido. O níquel acelera a cinética de precipitação da fase $\sigma$ embora a fração volumétrica desta fase seja reduzida ${ }^{25}$, além de estabilizar a austenita ${ }^{19}$.

O nitrogênio substitui o níquel e estabiliza a austenita ${ }^{19}$, aumentando em parte a resistência à corrosão e a estabilidade estrutural, assim como a resistência mecânica do material. É um endurecedor da solução sólida que contribui para a elevada resistência dos AIDs. Além disso, um elevado teor de nitrogênio melhora a re-formação da austenita após a soldagem, o que garante boas propriedades nas juntas soldadas, já que o nitrogênio é um elemento estabilizador da austenita em AIDs. Não só o nitrogênio melhora essas propriedades mecânicas e de resistência à corrosão por pites e em frestas, mas a presença de nitrogênio retarda a formação da fase $\sigma^{17152526}$.

Quando os AIDs apresentam elevados teores de cromo, nitrogênio, cobre e tungstênio em combinação com relativamente baixos teores de níquel e molibdênio, os aços exibem uma elevada resistência à corrosão especialmente em ambientes ácidos ou básicos com elevadas concentrações de cloreto ${ }^{15}$.

Nos AIDs modernos o teor de carbono é geralmente mantido bastante baixo $<0,02 \%$, devido a afinidade do cromo com o carbono que conduz à corrosão intergranular durante a soldagem ${ }^{27}$ e também para minimizar a precipitação de carbonetos intergranulares ${ }^{13}$. Geralmente apenas os aços inoxidáveis martensíticos têm o carbono como elemento de liga com teores de $0,1-1,5 \%{ }^{27}$.

Os elementos de liga cromo, molibdênio e níquel além de melhorar as propriedades mecânicas dos AIDs também podem provocar a precipitação de fases secundárias como $\sigma, \chi$, e $\mathrm{Cr}_{2} \mathrm{~N}$ durante o processo de fabricação ou soldagem. Essa precipitação faz que se deteriore a resistência à corrosão e fragiliza aos AIDs ${ }^{24}$. 


\section{4 .}

\section{Classificação dos AIDs}

A primeira geração dos AIDs vem sendo utilizada há muitos anos. O desenvolvimento de técnicas de soldagem e melhoria da soldabilidade destes aços, além do aumento da resistência à corrosão destas ligas, resultou nas ligas de segunda geração, que são caracterizadas pela adição de nitrogênio como um elemento de liga ${ }^{13}$.

A segunda geração de AIDs geralmente possui uma mistura de $50 \%$ de ferrita \% e 50\% de austenita. As novas ligas combinam a resistência à fissuração por CST em presença de cloretos dos aços inoxidáveis ferríticos com a tenacidade e a facilidade de fabricação dos aços inoxidáveis austeníticos. Entre os AIDs de segunda geração, a liga SAF 2205 a qual se tornou num aço inoxidável de aplicação geral. Na Tabela 3-1 estão listadas as composições nominais de AIDs de primeira e segunda geração ${ }^{13} 14$.

Tabela 3-1. Composições nominais dos AIDs de primeira e segunda geração.

\begin{tabular}{|c|c|c|c|c|c|c|c|}
\hline \multirow{2}{*}{$\begin{array}{l}\text { Designação } \\
\text { UNS }\end{array}$} & \multirow{2}{*}{ Nome comum } & \multicolumn{5}{|c|}{ Composição, \% * } & \multirow{2}{*}{ Outros } \\
\hline & & $\mathrm{Cr}$ & $\mathrm{Ni}$ & Mo & $\mathrm{Cu}$ & $\mathbf{N}$ & \\
\hline \multicolumn{8}{|c|}{ Primeira geração } \\
\hline S31500 & 3RE60 & 18,5 & 4,7 & 2,7 & & . & $1,7 \mathrm{Si}$ \\
\hline S32404 & Uranus 50 & 21 & 7,0 & 2,5 & 1,5 & $\ldots$ & $\ldots$ \\
\hline S32900 & Type 329 & 26 & 4,5 & 1,5 & $\ldots$ & $\ldots$ & \\
\hline J93370 & $\mathrm{CD}-4 \mathrm{MCu}$ & 25 & 5 & 2 & 3 & $\ldots$ & $\ldots$ \\
\hline \multicolumn{8}{|c|}{ Segunda geração } \\
\hline S31200 & $44 \mathrm{LN}$ & 25 & 6 & 1,7 & $\ldots$ & 0,15 & $\ldots$ \\
\hline S31260 & $\mathrm{DP}-3$ & 25 & 7 & 3 & 0,5 & 0,15 & $0,3 \mathrm{~W}$ \\
\hline S31803 & Alloy 2205 & 22 & 5 & 3 & $\ldots$ & $0,08-0,020$ & $\ldots$ \\
\hline S32304 & SAF 2304 & 23 & 4 & $\ldots$ & $\ldots$ & $0,05-0,020$ & $\ldots$ \\
\hline S32550 & Ferralium 255 & 25 & 6 & 3 & 2 & 0,20 & \\
\hline S32750 & SAF 2507 & 25 & 7 & 4 & $\ldots$ & $0,24-0,32$ & $\ldots$ \\
\hline S32950 & 7-Mo PLUS & 26,5 & 4,8 & 1,5 & $\ldots$ & 0,20 & \\
\hline J93404 & Atlas 958, COR 25 & 25 & 7 & 4,5 & $\ldots$ & 0,25 & $\ldots$ \\
\hline
\end{tabular}

* Todas as composições contém Fe (balanço).

Os AIDs de um modo geral são definidos de acordo com o PRE, que é uma medida empírica para avaliar a resistência à corrosão localizada de vários tipos de aços inoxidáveis a partir da composição química e é comumente usada para classificar a família a qual pertence uma dada liga. 
A norma ASTM G48-11 ${ }^{28}$ é amplamente usada para pré-avaliar a resistência à corrosão por pites e em frestas em ligas e juntas soldadas na indústria de petróleo e gás. Em geral, quanto maior o valor do PRE maior é a resistência à corrosão por pites do aço. O valor de PRE é função dos elementos de liga, como descrito anteriormente que influenciam a resistência à corrosão 22.

Existem diferentes equações de PRE, e cada uma considera a presença de diferentes elementos de liga. Por exemplo, o PRE é muitas vezes definido como 29 .

$\mathrm{PRE}=w t \% \mathrm{Cr}+3,3 \mathrm{wt} \% \mathrm{Mo}$

Equação 3-1

A resistência à corrosão por pites em aços inoxidáveis está principalmente relacionada com o teor de cromo, molibdênio e nitrogênio. O nitrogênio é um importante endurecedor da solução sólida que contribui à elevada resistência dos AIDs 172030312432 33. A equação do PRE incorpora este elemento e passa a ser escrita como $\mathrm{PRE}_{\mathrm{N}}$ na Equação 3-2:

$\mathrm{PRE}_{\mathrm{N}}=w t \% \mathrm{Cr}+3,3 \mathrm{wt} \% \mathrm{Mo}+16 \mathrm{wt} \% \mathrm{~N}$

Equação 3-2

Quando algumas ligas contêm uma adição de tungstênio, que é outro elemento que atua aumentando a resistência à corrosão por pites nos aços inoxidáveis ${ }^{34} 35{ }^{15}$, o tungstênio é incorporado no PRE passando a ser PREw na Equação 3-3:

$P R E_{W}=w t \% C r+3,3(w t \% M o+0,5 w t \% w)+16 w t \% N$

Equação 3-3

Alguns pesquisadores propõem uma formula modificada da Equação 3-3, onde o coeficiente empírico de 0,5 para o tungstênio foi deduzido da proporção massa atômica do molibdênio (96) até o tungstênio (184) ${ }^{24}$ :

$\mathrm{PRE}_{\mathrm{w}}=\mathrm{wt} \% \mathrm{Cr}+3,3 \mathrm{wt} \% \mathrm{Mo}+0,5 \mathrm{wt} \% \mathrm{~W}+16 \mathrm{wt} \% \mathrm{~N}$

Equação 3-4

Pelo menos quatro tipos diferentes de AIDs podem ser identificados ${ }^{17}$ :

- AIDs de baixo custo e livres de molibdênio do tipo $23 \mathrm{Cr}-4 \mathrm{Ni}-0,1 \mathrm{~N}$, estes aços fornecem alternativas aos aços inoxidáveis AISI 304 (UNS S30400) e 316 (UNS S31600).

- AIDs do tipo $22 \mathrm{Cr}-5 \mathrm{Ni}-3 \mathrm{Mo}-0,17 \mathrm{~N}$, cuja resistência à corrosão encontra-se entre AISI 316 e os graus super austeníticos 6\%Mo + N.

- AIDs de $25 \% \mathrm{Cr}$ com variação dos teores de molibdênio e nitrogênio, algumas vezes com adição de cobre e tungstênio, os valores do $P R E_{N}$ encontram-se na faixa de 30 - 39.

- Aços inoxidáveis super duplex do tipo $25 \mathrm{Cr}-7 \mathrm{Ni}-3,7 \mathrm{Mo}-0,27 \mathrm{~N}$ com valores de $\mathrm{PRE}_{\mathrm{N}}$ maiores do que 40. 
Uma lista dos AIDs forjados mais comuns que estão comercialmente disponíveis são mostrados na Tabela 3-2 junto com o nome comercial, o fabricante, a designação standard, e o valor $P R E_{N}$ definido de acordo com a Equação 3-2 dada acima ${ }^{17}$.

Tabela 3-2. Composição química (\% em peso) dos AIDs forjados mais comuns ${ }^{17}$.

\begin{tabular}{|l|l|l|c|c|c|c|c|c|}
\hline $\begin{array}{l}\text { Nome } \\
\text { comercial }\end{array}$ & Fabricante & $\begin{array}{l}\text { Designação } \\
\text { Standard }\end{array}$ & $\mathbf{C r}$ & $\mathbf{M o}$ & $\mathbf{N i}$ & $\mathbf{N}$ & $\begin{array}{c}\text { Outros } \\
\text { elementos }\end{array}$ & PRE $_{\mathbf{N}}$ \\
\hline SAF 2304 & $\begin{array}{l}\text { Sandvik, } \\
\text { Avesta }\end{array}$ & UNS S32304 & $\mathbf{2 3}$ & $\mathbf{0 , 2}$ & $\mathbf{4}$ & $\mathbf{0 , 1}$ & $\ldots$ & $\mathbf{2 5}$ \\
\hline UR 35N & Creusot-Loire & UNS S32304 & 23 & 0,2 & 4 & 0,1 & $\ldots$ & 25 \\
\hline 3RE60 & $\begin{array}{l}\text { Sandvik, } \\
\text { Avesta }\end{array}$ & UNS S31500 & 18,5 & 2,7 & 5 & 0,07 & $1,5 \mathrm{Si}$ & 29 \\
\hline UR45N & Creusot-Loire & UNS S31803 & 22 & 3 & 5,3 & 0,17 & $\ldots$ & 35 \\
\hline SAF 2205 & Sandvik & UNS S31803 & $\mathbf{2 2}$ & $\mathbf{3}$ & $\mathbf{5 , 3}$ & $\mathbf{0 , 1 7}$ & $\ldots$ & $\mathbf{3 5}$ \\
\hline 2205 & Avesta & UNS S31803 & 22 & 3 & 5,3 & 0,17 & $\ldots$ & 35 \\
\hline FALC223 & KruppStahl & UNS S31803 & 22 & 3 & 5,3 & 0,17 & $\ldots$ & 35 \\
\hline AF 22 & Mannesmann & UNS S31803 & 22 & 3 & 5,3 & 0,17 & $\ldots$ & 35 \\
\hline VS 22 & Valinos & UNS S31803 & 22 & 3 & 5,3 & 0,17 & $\ldots$ & 35 \\
\hline 10RE51 & Sandvik & UNS S32900 & 25 & 1,5 & 4,5 & $\ldots$ & $\ldots$ & 30 \\
\hline DP 3 & Sumitomo & UNS S31260 & 25 & 3 & 6,5 & 0,16 & $\begin{array}{c}\ldots, 5 \mathrm{Cu} \\
0,3 \mathrm{~W}\end{array}$ & 37 \\
\hline UR 52N & Creusot-Loire & UNS S32550 & 25 & 3 & 6,5 & 0,18 & $1,6 \mathrm{Cu}$ & 38 \\
\hline $\begin{array}{l}\text { Ferralium } \\
\text { 255 }\end{array}$ & $\begin{array}{l}\text { Langley } \\
\text { Alloys }\end{array}$ & UNS S32550 & 25 & 3 & 6,5 & 0,18 & $1,6 \mathrm{Cu}$ & 38 \\
\hline UR 47N & Creusot-Loire & UNS S32200 & 25 & 3 & 6,5 & 0,18 & $\ldots$ & 38 \\
\hline Zeron 100 & Weir & UNS S32760 & 25 & 3,6 & 7 & 0,25 & $\begin{array}{l}\text { 0,7Cu } \\
0,7 \mathrm{~W}\end{array}$ & 41 \\
\hline UR 52N+ & Creusot-Loire & UNS S32550 & 25 & 3,8 & 6 & 0,26 & $1,5 \mathrm{Cu}$ & 42 \\
\hline SAF 2507 & $\begin{array}{l}\text { Sandvik, } \\
\text { Avesta }\end{array}$ & UNS S32750 & $\mathbf{2 5}$ & $\mathbf{3 , 8}$ & $\mathbf{7}$ & $\mathbf{0 , 2 7}$ & $\ldots$ & $\mathbf{4 2}$ \\
\hline
\end{tabular}

Os AIDs continuam em desenvolvimento, e os AIDs modernos podem ser classificados em cinco grupos ${ }^{37}$ ou de acordo com o $\mathrm{PRE}_{\mathrm{N} / \mathrm{W}}{ }^{2}$ :

- Lean duplex, $P R E_{N / W} \sim 20-30$ 2. O lean duplex contém uma adição não deliberada de molibdênio ${ }^{37}$.

- Standard, $22 \% \mathrm{Cr}$ duplex, $\mathrm{PRE}_{\mathrm{N} / \mathrm{W}} \sim 35^{2}$, O standard duplex, é o grau duplex versátil, é $80 \%$ mais usado nos duplex ${ }^{37}$.

- $25 \%$ Cr duplex, $\mathrm{PRE}_{\mathrm{N} / \mathrm{W}} \sim 35-40^{2}$, O $25 \mathrm{Cr}$ duplex tem $\mathrm{PRE}_{\mathrm{N}}$ menor do que $40^{37}$.

- Superduplex, $P R E_{N / W} \sim 40-50^{2}$. O superduplex $\left(P_{R E} 40-45\right)$ contém 25 - $26 \mathrm{Cr}$, e Mo e N adicionado em comparação com o grau de $25 \% \mathrm{Cr}{ }^{37}$.

- Hyperduplex, $P R E_{N / W} \sim>50$ 2. O hyperduplex é definido como um aço inoxidável altamente ligado com um $\mathrm{PRE}_{\mathrm{N}}$ em excesso de $45^{37}$. 
Esta classificação é inevitavelmente um tanto arbitrária, já que não há um método padronizado ou de consenso geral de agrupamento dos aços duplex. A intenção é agrupar os aços de uma forma que possam refletir a composição e propriedades, indicando quais são os tipos de aços que podem ser vistos como contemporâneos e usando a definição comum de super duplex como aços com um PRE (PRE ${ }_{N}$ ou PREw) mínimo de 40.

Para os graus menos ligados o termo "lean" é usado principalmente para os graus quase livres de molibdênio com um baixo teor de níquel. No entanto, também os graus com teor intermediário de molibdênio ou com significativas adições de cobre são também classificadas como lean, pois têm $\mathrm{PRE}_{N}$ significativamente mais baixo do que o grau standard $22 \%$ de $\mathrm{Cr}$. Para os graus altamente ligados existe um problema semelhante na definição da fronteira entre super duplex e hyper duplex. Aqui, os graus são considerados hyper duplex quando $\mathrm{PRE}_{\mathrm{N}}$ ou PREw estão perto ou acima de $50^{2}$.

\section{5.}

\section{Fases Secundárias}

Os AIDs geralmente têm maior teor de cromo e menor teor de níquel do que os aços inoxidáveis convencionais, e geralmente contêm molibdênio para dar maior resistência à corrosão. Além disso, os AIDs contêm nitrogênio, que melhora a resistência à corrosão e também ajuda a formação da austenita, produzindo desse modo uma proporção equilibrada de ferrita/austenita. Os altos teores de cromo e molibdênio, junto com adição de nitrogênio, dão boa resistência à corrosão por pites e corrosão geral e os AIDs forjados ou fundidos têm encontrado aplicação em uma variedade de ambientes industriais ${ }^{38}$.

Embora, durante os processos de fabricação como a soldagem, a proporção de fases austenita-ferrita pode mudar junto com a precipitação de fases intermetálicas (fase $\sigma$, fase $\chi, \mathrm{Cr}_{23} \mathrm{C}_{6}, \mathrm{Cr}_{2} \mathrm{~N}, \gamma_{2}$, etc.). Na ZTA, a proporção austenita-ferrita tende a mudar de 1:1 em função do ciclo térmico da soldagem e da composição de aço. Diferentes relações de $\mathrm{Cr}_{\mathrm{eq}} / \mathrm{Ni}_{\mathrm{eq}}$, temperatura de pico, aporte de calor, temperatura de preaquecimento e velocidade de resfriamento causam a formação de ferrita e austenita com diferentes tamanhos de grão e frações volumétricas. Do mesmo modo, esses fatores afetam as formações de nitretos de cromo $\left(\mathrm{Cr}_{2} \mathrm{~N}\right)$ e outros precipitados ${ }^{39}$.

Durante o resfriamento a partir da temperatura de liquidus, os AIDs solidificam totalmente em única fase ferrita $\delta$ (Figura 3-1) antes de sofrer uma 
transformação parcial no estado sólido para austenita. Por outro lado, durante a soldagem, as regiões expostas a alta temperatura na ZTA se transformam completamente em uma estrutura ferrítica, ocorrendo também o crescimento do grão, de um modo similar ao que ocorre com os aços inoxidáveis ferríticos. Porém, ao contrário dos aços inoxidáveis ferríticos, a mudança na austenita ocorre durante o resfriamento com a re-formação da austenita intragranular e austenita intergranular. No entanto, as propriedades da ZTA ainda são dependentes da extensão da re-formação da austenita, e em condições desfavoráveis da soldagem a tenacidade e propriedades de corrosão podem ser afetadas devido ao teor muito alto da ferrita ${ }^{38}$.

No diagrama de fases $\mathrm{Fe}-\mathrm{Cr}-\mathrm{Ni}$ com $70 \%$ de ferro, na Figura 3-1 é ressaltada a região onde se encontram localizados os três AIDs deste trabalho, o lean duplex UNS S32304 (2304), o duplex UNS S32205 (SAF 2205) e o super duplex UNS S32750 (SAF 2507).

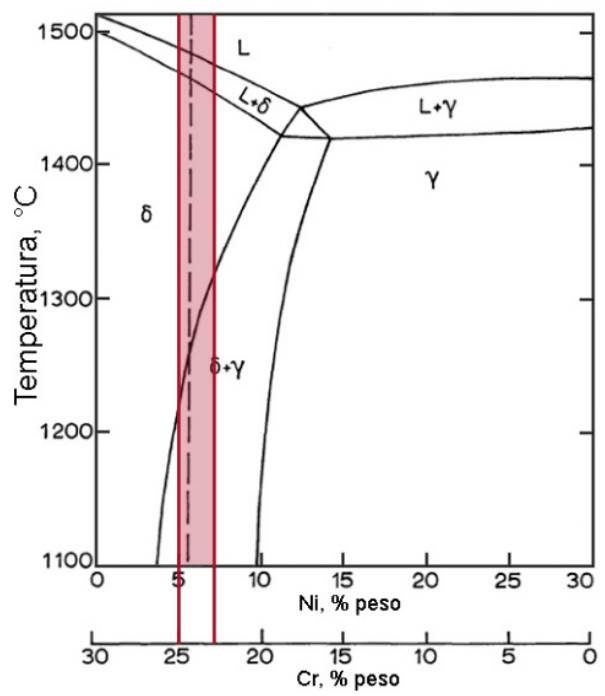

Figura 3-1. Diagrama de fases $\mathrm{Fe}-\mathrm{Cr}-\mathrm{Ni}$ em $70 \% \mathrm{Fe}$ mostrando a solidificação da ferrita em AIDs típicos ${ }^{38}$.

Na Figura 3-2 é mostrada uma seção do diagrama ternário $\mathrm{Fe}-\mathrm{Cr}-\mathrm{Ni}$ com $60 \%$ de ferro. Esta seção é representativa do UNS S32205 (SAF 2205), objeto deste trabalho. O diagrama prediz que a solidificação primária deste aço ocorre como ferrita $\delta$ e que a estrutura é completamente ferrítica a temperatura ambiente. Durante o resfriamento no estado sólido, a transformação parcial de ferrita em austenita ocorre a temperaturas inferiores nas quais a ferrita se dissolve. A quantidade de austenita formada durante o resfriamento no estado sólido depende 
da velocidade do resfriamento. No caso da soldagem, se a velocidade de resfriamento for lenta (isso ocorre para alto aporte de calor), a transformação da ferrita em austenita ocorre facilmente, resultando em uma microestrutura com alta fração volumétrica de austenita. Para soldagem que resulte em alta velocidade de resfriamento (a qual ocorre para baixo aporte de calor) pode resultar em uma microestrutura com baixa quantidade de austenita em relação às soldagens realizadas com velocidade de resfriamento lenta ${ }^{40}$. O efeito do aumento do nitrogênio também é mostrado nesta figura ${ }^{15}$.

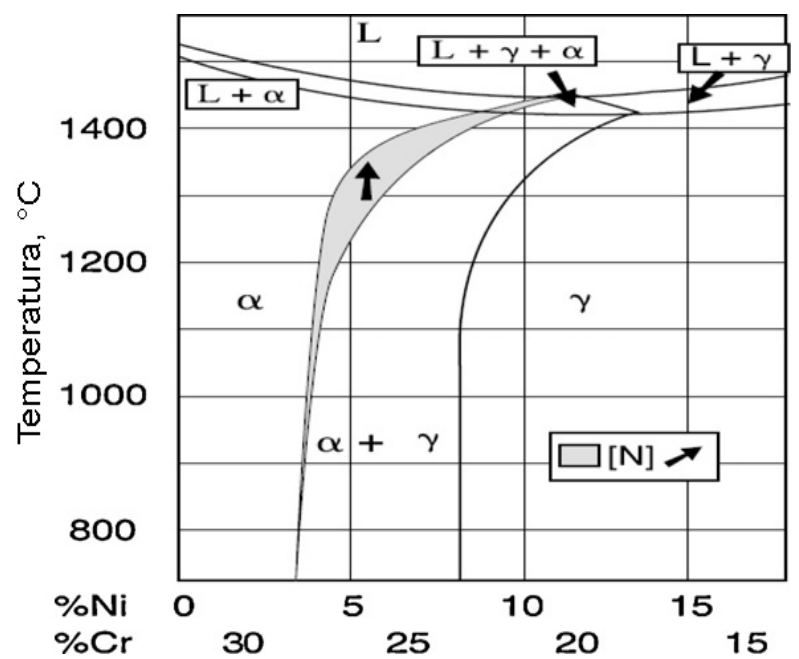

Figura 3-2. Seção de Fe constante do diagrama de fases ternário $\mathrm{Fe}-\mathrm{Cr}-\mathrm{Ni}$ com $60 \% \mathrm{Fe}{ }^{40}$.

Normalmente, os mecanismos de solidificação dos aços inoxidáveis são previstos a partir do diagrama ternário de $\mathrm{Fe}-\mathrm{Ni}-\mathrm{Cr}$ ou alternativamente utilizando diagramas pseudo binários (Figura 3-3) e a razão entre cromo e níquel equivalente $\left(\mathrm{Cr}_{\text {eq }} / \mathrm{Ni}_{\text {eq }}\right)$.

Em estudos de aços inoxidáveis super duplex, os $\mathrm{Cr}$ e Ni equivalentes foram calculados com as Equações 2-5 ${ }^{41}$, 2-6 ${ }^{42}$ e 2-7 ${ }^{1}$.

$$
\begin{aligned}
& \mathrm{Cr}_{\text {eq }}=\% \mathrm{Cr}+1,5 \% \mathrm{Si}+1,4 \% \mathrm{Mo}+\% \mathrm{Nb}-4,99 \\
& \mathrm{Ni}_{\text {eq }}=\% \mathrm{Ni}+30 \% \mathrm{C}+0,5 \% \mathrm{Mn}+26(\% \mathrm{~N}-0,02)+2,77 \\
& \mathrm{Cr}_{\text {eq }}=\% \mathrm{Cr}+\% \mathrm{Mo}+1,5 \% \mathrm{Si}+1,5 \% \mathrm{Nb} \\
& \mathrm{Ni}_{\text {eq }}=\% \mathrm{Ni}+30 \% \mathrm{C}+0,5 \% \mathrm{Mn}
\end{aligned}
$$

Os $\mathrm{Cr}$ e Ni equivalentes foram calculados com a Equação 3-7 ${ }^{43}$ em estudos do aço lean duplex 2304. Essas fórmulas de $\mathrm{Cr}$ e Ni equivalentes na Equação 37 foram obtidas por Long e Delong em $1973^{143}$ : 


$$
\begin{aligned}
& \mathrm{Cr}_{\text {eq }}=\% \mathrm{Cr}+\% \mathrm{Mo}+1,5 \% \mathrm{Si}+0,5 \% \mathrm{Nb} \\
& \mathrm{Ni}_{\text {eq }}=\% \mathrm{Ni}+30 \% \mathrm{C}+0,5 \% \mathrm{Mn}+30 \% \mathrm{~N}
\end{aligned}
$$

O Welding Research Council no ano de 1992 sugeriu as fórmulas da Equação 3-8 que são as mais razoáveis do que as formulas de Long e Delong e que são usadas em estudos do duplex 2205 e lean duplex 2304 44; 45464743 . Essas fórmulas predizem o $\mathrm{Cr}$ e $\mathrm{Ni}$ equivalentes especificamente nos aços inoxidáveis e incluem um coeficiente para o cobre e é removido o coeficiente de manganês no cálculo de Ni equivalente.

$$
\begin{aligned}
& \mathrm{Cr}_{\text {eq }}=\% \mathrm{Cr}+\% \mathrm{Mo}+0,7 \% \mathrm{Nb} \\
& \mathrm{Ni}_{\text {eq }}=\% \mathrm{Ni}+35 \% \mathrm{C}+20 \% \mathrm{~N}+0,25 \% \mathrm{Cu}
\end{aligned}
$$

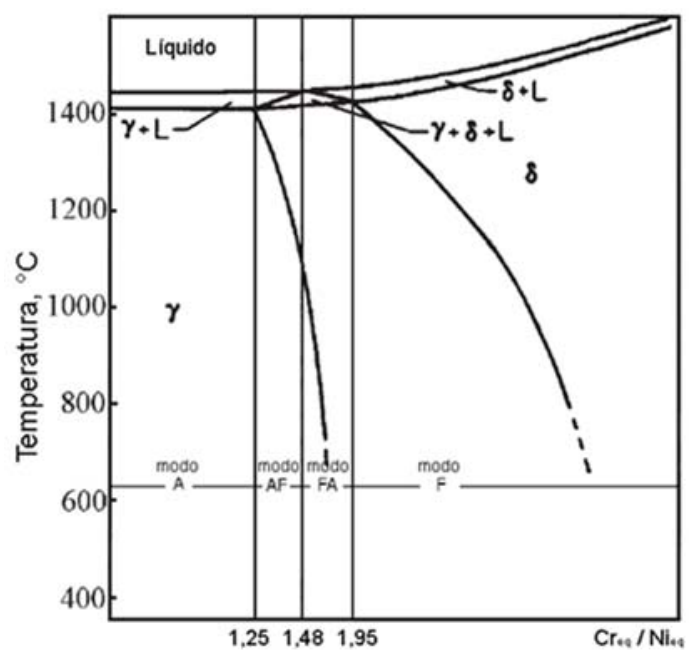

Figura 3-3. Predição do modo da solidificação em aços inoxidáveis usando o conceito de $\mathrm{Cr}$ e $\mathrm{Ni}$ equivalente ${ }^{46}$.

Dependendo da composição, espera-se a formação de uma quantidade variável de austenita. Na sequência de transformação esta será a última fase a se formar, podendo precipitar nos contornos de grão da ferrita na faixa de temperatura de 1400 e $1200^{\circ} \mathrm{C}$ (Figura 3-4). Caso ocorra um recozimento a austenita pode vir a se precipitar na fase sólida. Essa sequência de eventos poderá levar a uma fração volumétrica de austenita maior do que um material fundido ou soldado (as-welded material). Uma quantidade suficiente de austenita deve ser mantida de modo a prover a resistência à corrosão e propriedades mecânicas satisfatórias. Essa quantidade de austenita pode variar com a composição e a história térmica do aço ${ }^{33}$. 


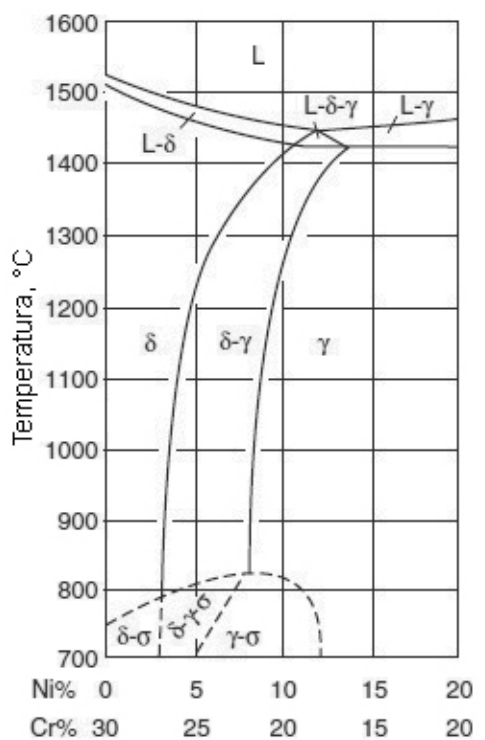

Figura 3-4. Seção do diagrama ternário $\mathrm{Fe}-\mathrm{Cr}-\mathrm{Ni}$ (\% em peso) com $65 \%$ em peso de $\mathrm{Fe}^{33}$.

A presença e o equilíbrio de fases austenita, ferrita e a fase $\sigma$ são mostrados no diagrama ternário de $\mathrm{Fe}-\mathrm{Cr}$-Ni na Figura 3-5. É um diagrama básico para aços inoxidáveis e mostra que para uma alta razão $\mathrm{Cr} /$ Ni pode ocorrer precipitação da fase $\sigma$ durante o envelhecimento a temperaturas entre 550 e $900^{\circ} \mathrm{C} 33$.

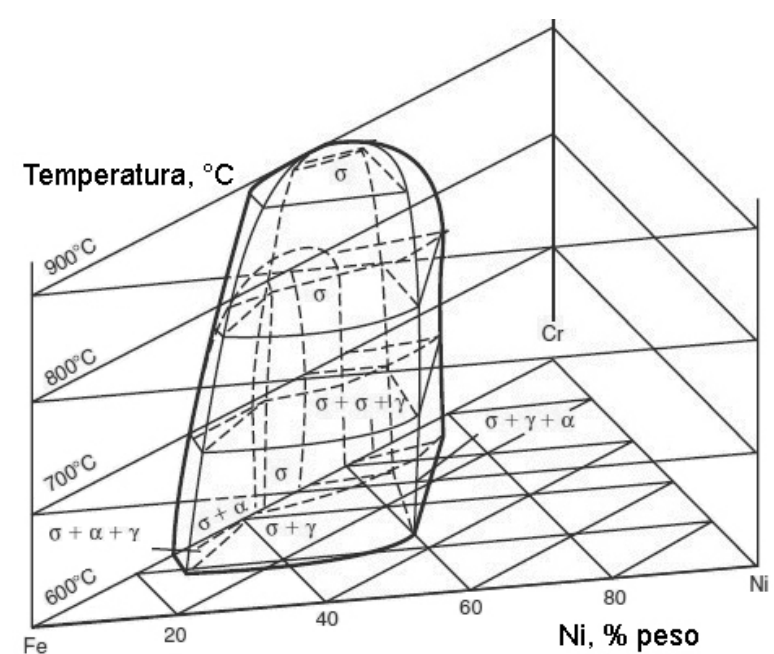

Figura 3-5. Vista tridimensional do digrama de equilíbrio $\mathrm{Fe}-\mathrm{Cr}-\mathrm{Ni}{ }^{33}$.

As fases de equilíbrio para o aço SAF 2205 foram calculadas utilizando o software Thermo-Calc versão $Q$ e a base de dados TCFE2 (Figura 3-6). O modelo considera os efeitos de $\mathrm{Fe}, \mathrm{Cr}, \mathrm{Ni}, \mathrm{Mo}, \mathrm{Mn}, \mathrm{Si}, \mathrm{C}$ e $\mathrm{N}$ na ferrita, austenita, fase $\sigma$, nitretos / carbonetos e as fases liquidas. Estes diagramas fornecem a fração volumétrica de fase calculada contra temperatura, e indicam para o SAF 2205 que 
a ferrita se transforma em austenita e fase $\sigma$ durante o aquecimento até $700^{\circ} \mathrm{C}$. Entre 700 e $800^{\circ} \mathrm{C}$ a ferrita se transforma completamente e não está mais presente. A $800^{\circ} \mathrm{C}$ a ferrita se começa a re-formar, e a fase $\sigma$ continua diminuindo até que desaparece completamente a uma temperatura de aproximadamente $860^{\circ} \mathrm{C}$. Com o aumento da temperatura, a ferrita aumenta e a austenita diminui até atingir quantidades iguais em $1065^{\circ} \mathrm{C}$. A microestrutura inicial do SAF 2205 é metastável devido à têmpera a partir de temperaturas elevadas (própria do processo de fabricação do aço SAF 2205), embora a microestrutura predita a partir dos cálculos termodinâmicos começa com uma proporção de ferrita / austenita significativamente diferente ${ }^{48}$.

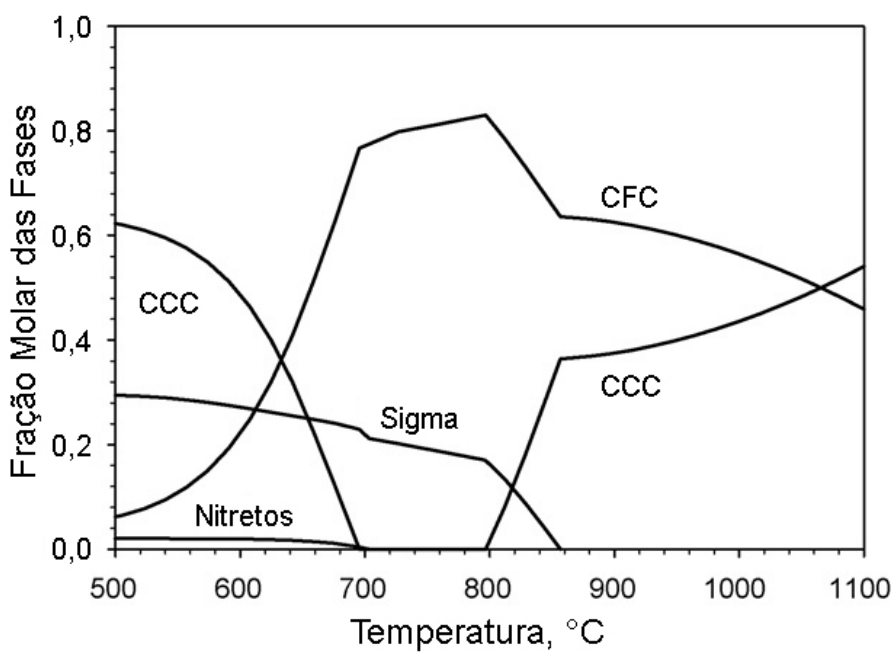

Figura 3-6. Frações de fases calculadas para o SAF 2205. A fase $\sigma$ é predita a temperaturas menores do que $860^{\circ} \mathrm{C}^{48}$.

A Figura 3-7 mostra as fases de equilíbrio presentes no SAF 2205 em função da temperatura, nesta ocasião os cálculos termodinâmicos foram feitos em EOLib (The Earth Observation image Librarian). A validação dos resultados calculados com os resultados experimentais mostra uma excelente concordância com o equilíbrio das fases conhecidas. A mudança nas quantidades da austenita e da ferrita está em concordância com os cálculos, a formação da fase $\sigma$ e da fase $\chi$ é corretamente prevista, assim como a formação do $\mathrm{M}_{23} \mathrm{C}_{6}$ e $\mathrm{Cr}_{2} \mathrm{~N}$. A Figura 3-7 mostra as fases presentes na maior parte dos AIDs; dependendo das diversas faixas de temperatura e composição química, a proporção de fases pode mudar, porém as fases que se formam são muito semelhantes na maioria dos aços deste tipo ${ }^{49}$. 


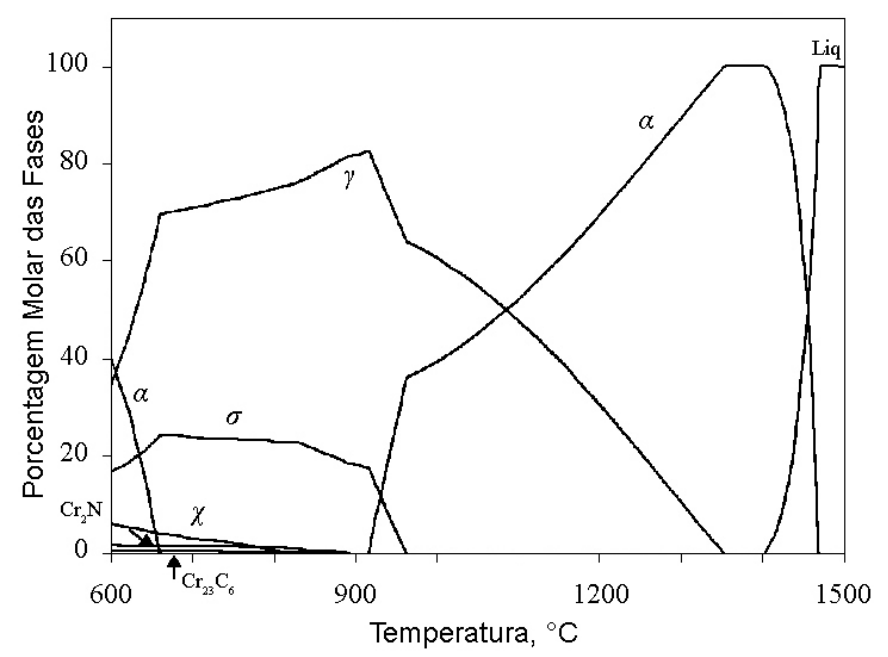

Figura 3-7. Fases calculadas vs temperatura do aço $2205^{49}$.

Observa-se que em versão mais recente do software Thermo-Calc versão 3.0 com a base de dados TCFE7 (Figura 3-8), para o aço SAF 2205 não se observa a fase $\chi^{22}$ como na simulação do mesmo aço na Figura 3-7.

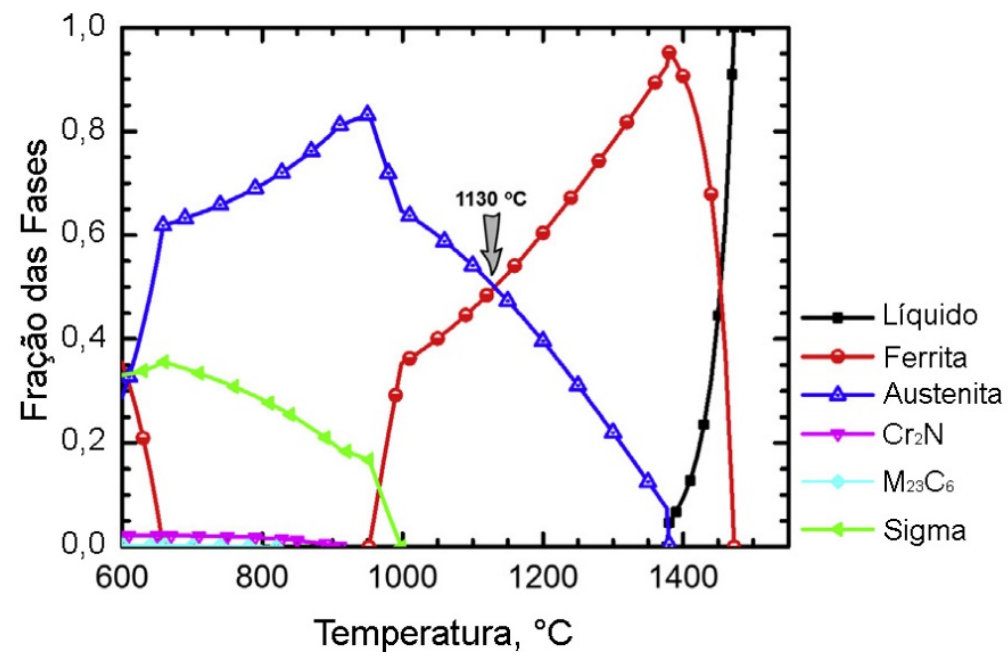

Figura 3-8. Diagrama de fase de SAF $2205^{22}$.

A Figura 3-9 mostra as fases em equilíbrio formadas no super duplex SAF 2507 em função da temperatura, os cálculos termodinâmicos foram feitos por EOLib. Similar ao SAF 2205 (Figura 3-7), a faixa de temperatura de equilíbrio para a formação da fase $\chi$ é bem menor do que da fase $\sigma$, mas a fase $\chi$ tem a cinética de transformação (nucleação) mais rápida ${ }^{49}$. 


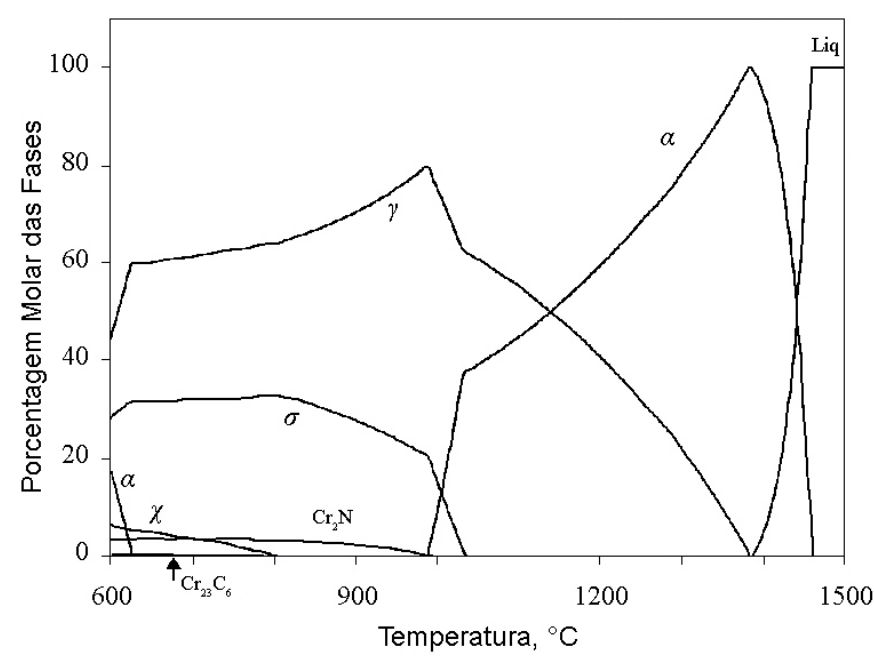

Figura 3-9. Diagrama de porcentagem molar de fases calculadas vs. temperatura do aço super duplex SAF $2507^{49}$.

Um modelo termodinâmico dos aços lean duplex 2304, duplex 2205 e super duplex 2507 baseado no método de CALPHAD (CALculation of PHAse Diagrams) e usando o software Thermo-Calc a base de dados TCFE3, resultaram nos diagramas mostrados na Figura 3-10. Nestes diagramas a fração molar das fases em função da temperatura apresenta um padrão similar mas com algumas diferenças significativas para os três aços: 50

- Na solidificação ocorre a fase sólida ferrítica que gradual e parcialmente se transforma em austenita com a redução da temperatura. Entre 1020 $1080^{\circ} \mathrm{C}$, austenita e ferrita coexistem em frações quase equivalentes.

- A temperaturas inferiores a $400^{\circ} \mathrm{C}$, a fase presente é ferrita, com alguns componentes em menor fração volumétrica que são a fase $\chi$, outras fases intermetálicas, carbonetos e nitretos de cromo.

- A temperatura máxima da formação da fase $\sigma$ diminui em função da composição química. Sendo em ordem decrescente de $1000^{\circ} \mathrm{C}$ até cerca de $850^{\circ} \mathrm{C}$, para os aços duplex 2507, duplex 2205 até o lean duplex 2304, respectivamente.

- Apenas nos graus super duplex 2507 e duplex 2205, no resfriamento a formação da fase $\sigma$ ocorre junto com a decomposição da ferrita que se transforma em fase $\sigma$ e austenita, depois a austenita se transforma parcialmente a ferrita deixando a fase $\sigma$ inalterada.

- Continuando o resfriamento, a baixas temperaturas nos graus 2507 e 2205, a austenita se transforma em ferrita. 
- O comportamento do aço 2304 aparece como intermediário: durante a formação da fase $\sigma$ (de 800 a $400^{\circ} \mathrm{C}$ ), a ferrita se transforma parcialmente a austenita secundária, portanto, uma quantidade significativa de ferrita permanece em toda a faixa de temperatura considerada.

- A formação da fase $\chi$ é prevista apenas para o duplex 2205 e o super duplex 2507 , esses graus têm maior teor de molibdênio, o que não acontece para o lean duplex 2304.

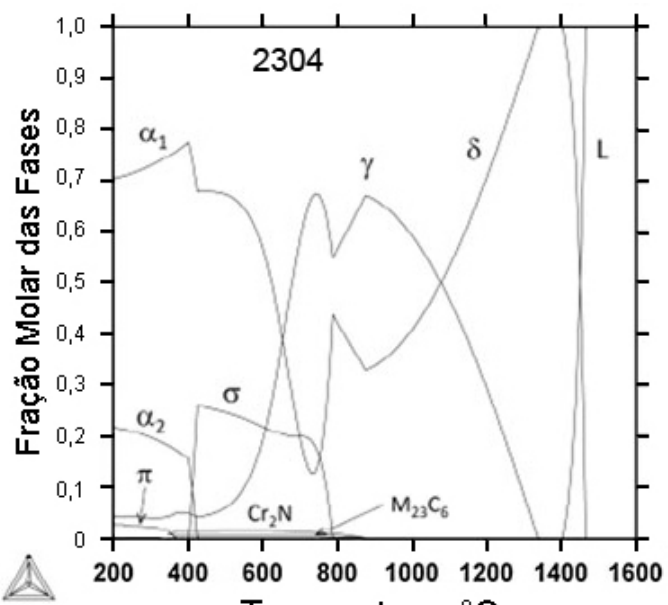

Temperatura, ${ }^{\circ} \mathrm{C}$
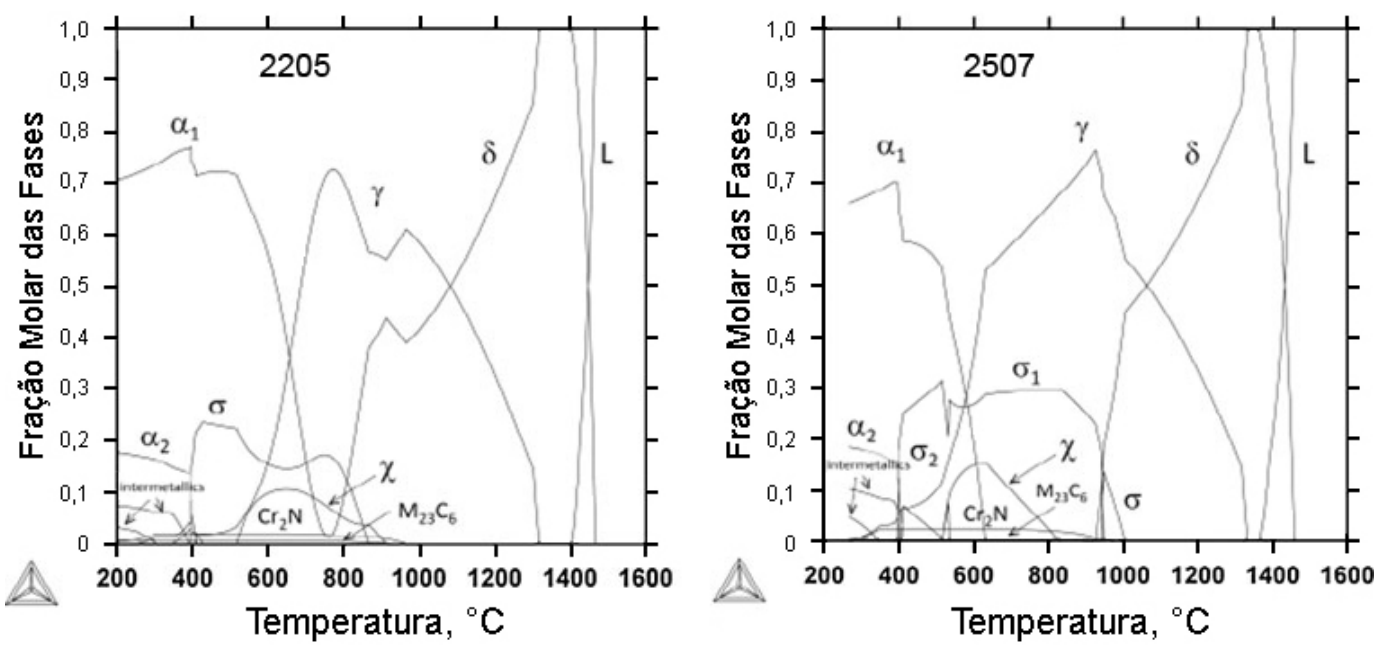

Figura 3-10. Diagramas de fase dos aços UNS S32304 (2304), UNS S32205 (2205) e UNS S32750 $(2507)^{50}$.

A Figura 3-11 mostra um diagrama de transformação isotérmica para o AID 2205, construído por várias fontes, simplificado e ignorando a decomposição de ferrita para austenita. Uma característica importante deste diagrama é que o início da precipitação de carboneto e de nitreto de cromo leva um tempo relativamente largo de 1 - 2 minutos, o qual é muito mais lento do que nos aços inoxidáveis 
ferríticos. Isso se deve em parte à alta solubilidade dos elementos intersticiais na fase austenítica, e possivelmente também ao efeito retardador do nitrogênio na cinética dos carbonetos. Como resultado, os AIDs são mais resistentes à sensitização ao frio do que os aços inoxidáveis ferríticos. As cinéticas dos carbonetos e nitretos são só um pouco afetadas pelo cromo, molibdênio e níquel nos graus duplex ${ }^{51}$. A maior parte dos AIDs têm uma cinética similar ao 2205 em relação a esses precipitados.

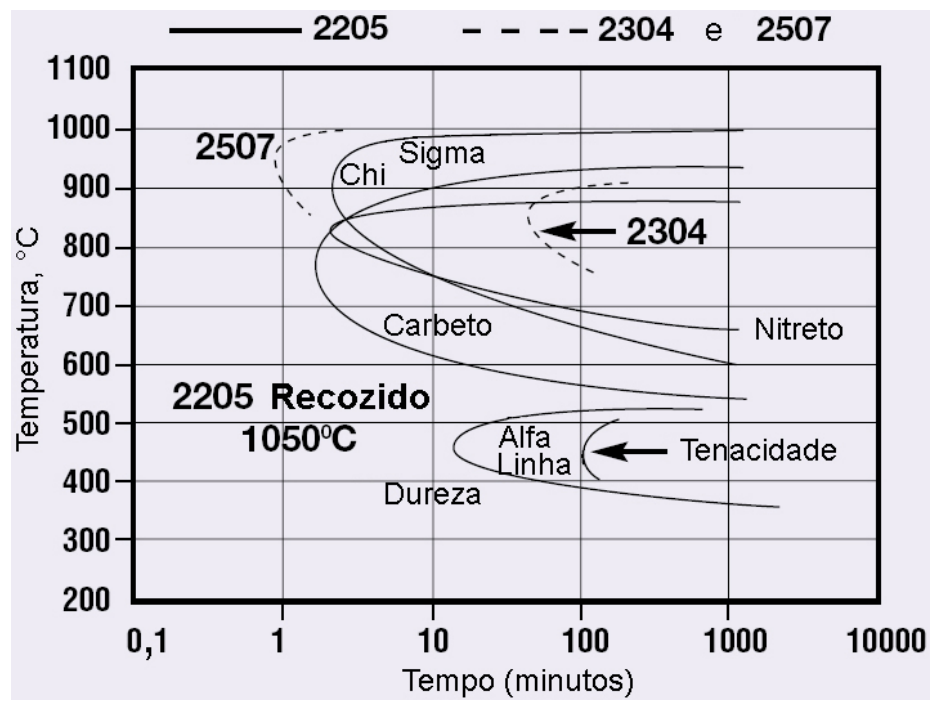

Figura 3-11. Cinética da precipitação isotérmica das fases secundárias em AID 2205 comparada com as cinéticas dos AIDs 2304 e $2507^{52}$.

A Figura 3-12 mostra um gráfico TTT geral dos AIDs, que ilustra as regiões de alta temperatura delimitadas pela curva "de forma de C" em que a fase $\sigma$, a fase $\chi$, carboneto do tipo $\mathrm{M}_{23} \mathrm{C}_{6}$ e nitreto de cromo $\mathrm{Cr}_{2} \mathrm{~N}$ podem precipitar, enquanto que a temperaturas menores pode ocorrer a precipitação da fase alfa linha . Este precipitado é rico em cromo e tem estrutura cúbica é coerente com a ferrita e têm uma enorme resistência à coalescência, mesmo para tempos de exposição muito longos na faixa de temperatura de 350 a $550^{\circ} \mathrm{C}$, é uma fase que causa uma perda significativa de tenacidade ${ }^{33}$. 


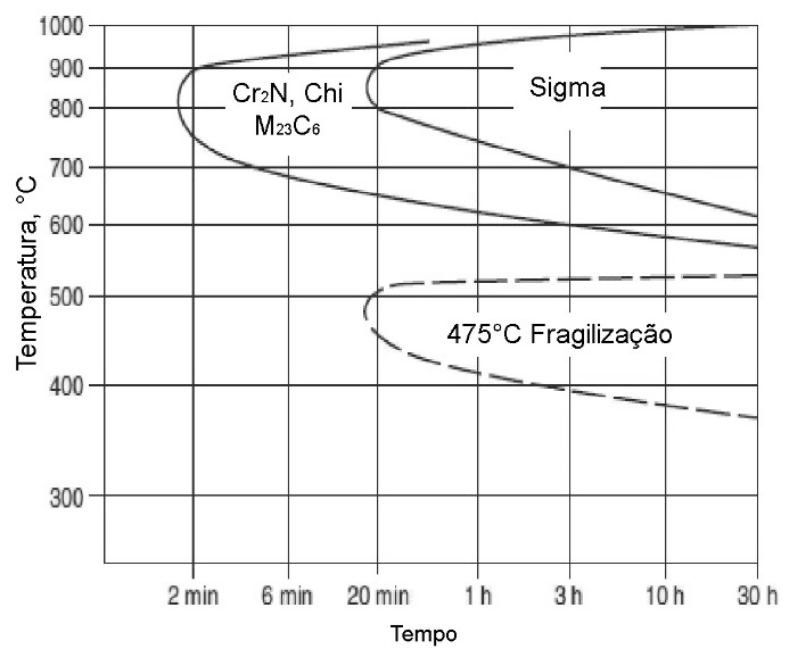

Figura 3-12. Gráfico TTT mostra a precipitação da fase $\sigma$, alpha linha e outras fases em AIDs ${ }^{33}$.

Nos AIDs além da ferrita $(\delta)$ e da austenita $(\gamma)$ uma grande variedade de fases secundárias indesejáveis pode-se formar na faixa de temperatura de 300 $1000^{\circ} \mathrm{C}$ durante um envelhecimento isotérmico como consequência da instabilidade da ferrita ${ }^{17}$.

De modo geral as seguintes fases tem sido identificadas nos AIDs: fase $\sigma$, $\mathrm{Cr}_{2} \mathrm{~N}, \mathrm{Cr}$, austenita secundária, fase $\chi$, fase $R$, fase $\pi, \mathrm{M}_{7} \mathrm{C}_{3}, \mathrm{M}_{23} \mathrm{C}_{6}$, Cu e fase $\tau$. Além disso, na faixa de $300-500^{\circ} \mathrm{C}$, pode ocorrer a decomposição espinodal da ferrita. Das fases mencionadas anteriormente, a fase $\sigma$ é considerada como sendo a mais importante em função da influência exercida sobre a tenacidade e na resistência à corrosão. Um resumo destas fases é dado na Tabela 3-3, assim como as faixas de temperatura de precipitação, os parâmetros de rede e estruturas cristalinas ${ }^{17}$. 
Tabela 3-3. Fases observadas nos aços inoxidáveis duplex 172153 32*.

\begin{tabular}{|c|c|c|c|c|c|c|}
\hline $\begin{array}{l}\text { Tipo de } \\
\text { precipitado }\end{array}$ & Formula química & Célula & $\begin{array}{l}\text { Temperatura de } \\
\text { formação em } \\
\text { AIDs, }\left[{ }^{\circ} \mathrm{C}\right]\end{array}$ & $\begin{array}{l}\text { Grupo } \\
\text { espacial }\end{array}$ & $\begin{array}{l}\text { Parâmetros de } \\
\text { rede, }[\mathrm{nm}]\end{array}$ & Propriedades \\
\hline Ferrita $(\delta)$ & (Fe,Cr,Ni,Mo) & $\mathrm{CCC}$ & $\begin{array}{l}\text { Todas as } \\
\text { temperaturas }\end{array}$ & $\operatorname{Im} \overline{3} m$ & $a=0,286-0,288$ & $\begin{array}{l}\text { Boa resistência à } \\
\text { corrosão. }\end{array}$ \\
\hline $\begin{array}{l}\text { Austenita } \\
\left(\gamma / \gamma_{2}\right)\end{array}$ & $(\mathrm{Fe}, \mathrm{Cr}, \mathrm{Ni}, \mathrm{Mo}, \mathrm{N})$ & CFC & $700-900\left(\gamma_{2}\right)$ & $F m \overline{3} m$ & $a=0,358-0,362$ & $\begin{array}{l}\text { Boas propriedades } \\
\text { mecânicas, } \gamma_{2} \text { pode ter } \\
\text { morfologia eutética. }\end{array}$ \\
\hline$\sigma$ & $(\mathrm{Fe}, \mathrm{Ni})_{\mathrm{x}}(\mathrm{Cr}, \mathrm{Mo})_{\mathrm{y}}$ & Tetragonal & $600-1000$ & $P 4_{2} / \mathrm{mnm}$ & $\begin{array}{l}a=0,879 \\
c=0,454\end{array}$ & $\begin{array}{l}\text { Prejudicial para as } \\
\text { propriedades mecânicas e } \\
\text { corrosão. }\end{array}$ \\
\hline $\begin{array}{l}\varepsilon \text { Nitreto de } \\
\text { cromo }\end{array}$ & $\mathrm{Cr}_{2} \mathrm{~N}$ & $\begin{array}{l}\text { Hexagonal } \\
\text { Trigonal * }\end{array}$ & $700-900$ & P31m & $\begin{array}{l}a=0,480 \\
c=0,447\end{array}$ & $\begin{array}{l}\text { Prejudicial para a } \\
\text { resistência à corrosão. }\end{array}$ \\
\hline $\begin{array}{l}\text { Nitreto de } \\
\text { cromo }\end{array}$ & $\mathrm{CrN}$ & Cúbico & $\ldots$ & $F m 3 m$ & $a=0,413-0,447$ & \\
\hline$\chi$ & $\begin{array}{l}\mathrm{Fe}_{36} \mathrm{Cr}_{12} \mathrm{Mo}_{10} \\
(\mathrm{Fe}, \mathrm{Ni})_{36} \mathrm{Cr}_{18} \mathrm{Mo}_{4}\end{array}$ & Cúbico & $700-900$ & $\overline{14} m$ & $a=0,892$ & $\begin{array}{l}\text { Semelhante a fase } \sigma, \text { mas } \\
\text { o teor de molibdênio é } \\
\text { maior ( } \approx 20 \% \text { em peso). }\end{array}$ \\
\hline$R$ & $\begin{array}{l}\mathrm{Fe}_{22} \mathrm{Mo}_{18} \mathrm{Cr}_{13} \\
(\mathrm{Fe}, \mathrm{Ni})_{10} \mathrm{Cr}_{5} \mathrm{Mo}_{3} \\
\mathrm{Si}_{2}\end{array}$ & Romboédrico & $550-650$ & R3 & $\begin{array}{l}a=1,090 \\
c=1,934\end{array}$ & $\begin{array}{l}\text { Fase rica em molibdênio } \\
(40 \% \text { em peso), } \\
\text { prejudicial para a } \\
\text { tenacidade e a resistência } \\
\text { à corrosão por pites. }\end{array}$ \\
\hline$\pi$ & $\mathrm{Fe}_{7} \mathrm{Mo}_{13} \mathrm{~N}_{4}$ & Cúbico & $\approx 600$ & $P 4,32$ & $a=0,647$ & $\begin{array}{l}\text { Prejudicial para a } \\
\text { tenacidade e a resistência } \\
\text { à corrosão por pites. }\end{array}$ \\
\hline$\tau$ & $\begin{array}{l}\text { Não } \\
\text { determinada }\end{array}$ & Ortorrômbico & $550-650$ & Fmmm & $\begin{array}{l}a=0,405 \\
b=0,484 \\
c=0,286\end{array}$ & \\
\hline \multirow{2}{*}{ Carbonetos } & $\begin{array}{l}\mathrm{M}_{23} \mathrm{C}_{6} \\
\left(\mathrm{Cr}, \mathrm{Fe}, \mathrm{Mo}_{23} \mathrm{C}_{6}\right. \\
\left(\mathrm{Cr}_{16} \mathrm{Fe}_{5} \mathrm{Mo}_{2}\right) \mathrm{C}_{6} \\
\end{array}$ & Cúbico & $600-950$ & $F m \overline{3} m$ & $a=1,056-1,065$ & \multirow{2}{*}{$\begin{array}{l}\text { É menos importante do } \\
\text { que as outras fases devidc } \\
\text { ao baixo teor de carbono } \\
\text { nos AIDs. }\end{array}$} \\
\hline & $\begin{array}{l}\mathrm{M}_{7} \mathrm{C}_{3} \\
(\mathrm{Cr}, \mathrm{Fe})_{7} \mathrm{C}_{3}\end{array}$ & Ortorrômbico & $950-1050$ & Pnma & $\begin{array}{l}a=0,452 \\
b=0,699 \\
c=1,211\end{array}$ & \\
\hline
\end{tabular}

\subsection{1.}

\section{Fase $\sigma$}

A fase $\sigma$ é uma fase intermetálica não magnética ${ }^{54}$ e frágil ${ }^{3}$, possui estrutura cristalina tetragonal complexa com célula unitária grande com $30^{3}$ - $32^{54}$ átomos por unidade de célula ${ }^{55}$. A fase $\sigma$ é um composto de $\mathrm{Fe}-\mathrm{Cr}-\mathrm{Mo}$ enriquecido em ferro, cromo, molibdênio, tungstênio e o silício, mas com baixo teor de níquel e manganês ${ }^{56}$. A fase $\sigma$ incrementa a dureza dos AIDs, mas reduz a tenacidade e o alongamento, e a medida que a quantidade de fase $\sigma$ aumenta muda o tipo de fratura de transgranular para intergranular ${ }^{54}$. A fase $\sigma$ é considerada a fase mais prejudicial devido ao seu potencial para formar uma quantidade significativa (até cerca de $30 \%$ em volume) nos AIDs ${ }^{21}$.

Os locais de nucleação comuns da fase $\sigma$ são os contornos de grãos de ferrita / austenita e se considera que as partículas de carbonetos nos contornos de grão facilitam a nucleação ${ }^{56}$, onde a fase $\sigma$ cresce a partir da ferrita que é enriquecida em cromo e molibdênio ${ }^{55}$. Dependendo da composição química do 
aço a fase $\sigma$ se pode formar dentro de uma ampla faixa de temperaturas de $600^{\circ} \mathrm{C}$ até $1000^{\circ} \mathrm{C}{ }^{56}$. O crescimento da fase $\sigma$ resulta na redução do cromo o do molibdênio ao redor do precipitado que está crescendo, reduzindo a resistência à corrosão ${ }^{3}$.

A fase $\sigma$ se forma para uma grande faixa de AIDs ${ }^{17}$. Esta situação se acentua em todos os aços super duplex em função do aumento no teor de cromo e molibdênio em comparação com os AIDs padrão. Como resultado a curva do diagrama de transformação isotérmica (gráfico TTT) da fase $\sigma$ é deslocada para tempos mais curtos (Figura 3-11) ${ }^{17}$.

O molibdênio é também conhecido por aumentar a faixa de estabilidade da fase $\sigma$ a temperaturas mais altas ${ }^{17}$. Estudos sobre a cinética de precipitação em aços super duplex mostram que o tungstênio e o molibdênio aumentam a velocidade de precipitação da fase $\sigma$ e expandem o gráfico TTT a temperaturas mais elevadas ${ }^{17}$. O cobre parece não ter efeito sobre a fase $\sigma^{17}$. Todos os efeitos acima observados devem ser levados em consideração durante a produção dos AIDs, uma vez que a fase $\sigma$ afeta negativamente a ductilidade a quente e a temperatura ambiente, a tenacidade ao impacto, e a resistência à corrosão por pites e em frestas 175556 .

Em termos morfológicos a precipitação da fase $\sigma$ ocorre frequentemente nas junções triplas ou nos contornos de grão ferrita / austenita; isto pode ser observado na Figura 3-13, onde se apresenta a microestrutura do aço super duplex SAF 2507 após envelhecimento isotérmico a $850^{\circ} \mathrm{C}{ }^{17}$. A análise química quantitativa mostra que o cromo, o molibdênio e o silício estão enriquecidos na fase $\sigma^{17}$. É importante observar que em uma grande quantidade de AIDs, o cromo e o molibdênio incrementam tanto a taxa de precipitação quanto a fração volumétrica da fase $\sigma$ 17. De um modo geral os aços super duplex são ricos em cromo e molibdênio e mais sensíveis do que os AIDs convencionais, necessitando de taxas de resfriamento mais rápidas de modo a evitar a precipitação de outras fases ${ }^{17}$. O níquel acelera a cinética de precipitação da fase $\sigma$, embora a fração volumétrica de equilíbrio seja reduzida ${ }^{17} 56$. 


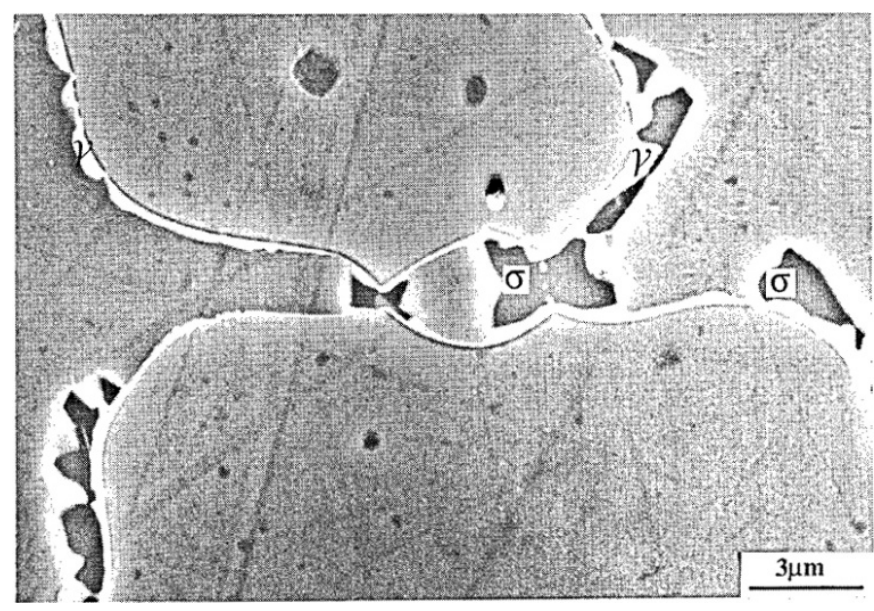

Figura 3-13. Microestrutura do SAF 2507 envelhecido durante $10 \mathrm{~min}$ a $850^{\circ} \mathrm{C}$, a fase $\sigma$ aparece precipitada nos contornos de grão ferrita / ferrita e nos contornos de grão austenita / austenita, a austenita secundária é visível com contraste brilhante entre a austenita primaria e a ferrita (MEV) ${ }^{17}$.

A precipitação da fase $\sigma$ ocorre antes da precipitação da fase $\chi$, algumas vezes precede a precipitação de carbonetos. É sugerido que a precipitação da fase $\sigma$ está associada à precipitação da fase $\chi$, o que significa que a fase $\chi$, se precipita antes da fase $\sigma^{57}$. No entanto tem sido detectado em alguns casos aos carbonetos como a primeira fase em precipitar ${ }^{57} 58$. Mas em todos os casos, a precipitação ocorre na interface $\sigma / \chi^{57}$.

A cinética da precipitação das fases intermetálicas é fortemente afetada tanto pela deformação plástica quanto pela temperatura do tratamento de solubilização. Portanto, a temperatura crítica para a formação da fase $\sigma$ e de outras fases depende tanto da temperatura do tratamento de solubilização quanto da velocidade de resfriamento depois da tempera ${ }^{57}$.

\subsection{2.}

\section{Nitretos de Cromo}

Com o aumento de nitrogênio como elemento de liga nos AIDs, e em particular nos aços super duplex, a precipitação de $\mathrm{Cr}_{2} \mathrm{~N}$ na faixa de temperatura de 700 até $900^{\circ} \mathrm{C}$ torna-se mais importante ${ }^{17}$. $\mathrm{O} \mathrm{Cr}_{2} \mathrm{~N}$ pode ser formado durante tratamentos térmicos de envelhecimento ou durante tratamentos térmicos de têmpera desde temperaturas de solubilização ${ }^{7}$. A formação de $\mathrm{Cr}_{2} \mathrm{~N}$ é passível de ocorrer a taxas de resfriamentos rápidas. Isso ocorre porque a matriz ferrítica fica supersaturada de nitrogênio, permitindo a precipitação frequentemente 
intragranular de partículas de $\mathrm{Cr}_{2} \mathrm{~N}$ com morfologia alongada e com relação cristalográfica $<0001>\mathrm{Cr}_{2} \mathrm{~N}$ II $<011>\delta$, conforme mostrado na Figura 3-14 ${ }^{17}$.

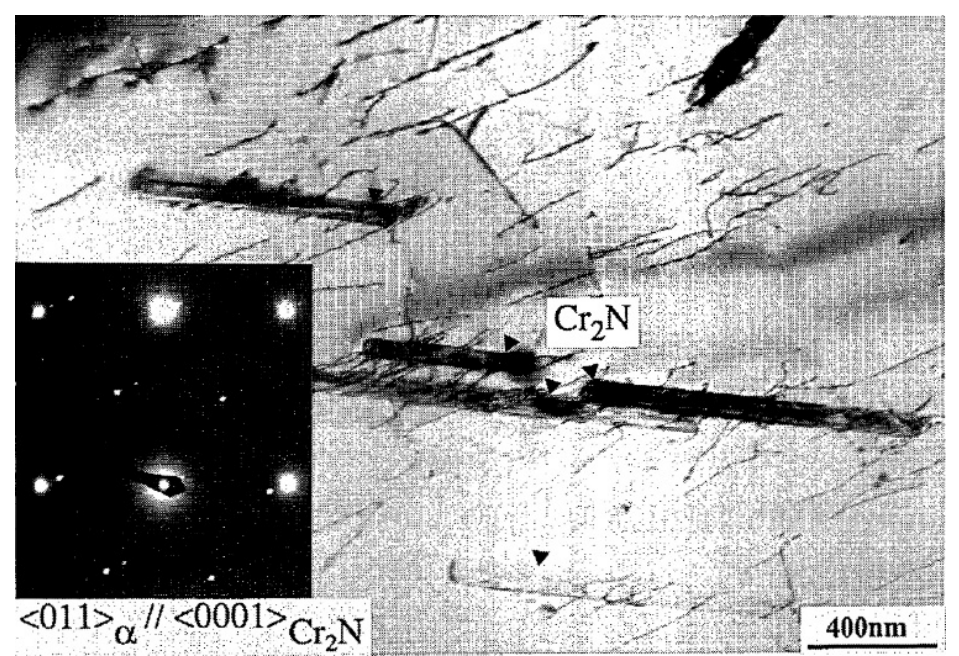

Figura 3-14. Imagem por MET de $\mathrm{Cr}_{2} \mathrm{~N}$ intragranular e austenita secundária formadas no SAF 2507 após tratamento de envelhecimento durante 10 minutos a $850^{\circ} \mathrm{C}{ }^{17}$.

O tratamento térmico isotérmico na faixa de 700 até $900^{\circ} \mathrm{C}$ geralmente resulta na precipitação de $\mathrm{Cr}_{2} \mathrm{~N}$ intergranular nos contornos de grão $\delta / \delta$ ou nos contornos de fase $\gamma / \delta$. O envelhecimento do aço super duplex 2507 a $850^{\circ} \mathrm{C}$ durante 10 min (Figura 3-15) permite a precipitação simultânea de $\mathrm{Cr}_{2} \mathrm{~N}$ nos

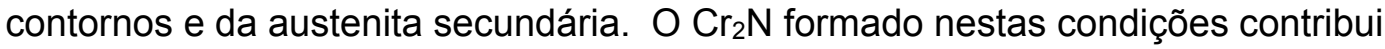
para a corrosão por pites ${ }^{17}$.

É interessante observar que o nitreto de cromo apresenta duas morfologias e cristalografias distintas. Enquanto que o $\mathrm{Cr}_{2} \mathrm{~N}$ é hexagonal, o $\mathrm{CrN}$ é cúbico (Figura 3-16) ${ }^{9} 53$.

Durante a soldagem dos AIDs a estrutura ferritizada se resfria rapidamente, a ferrita se supersatura em nitrogênio, resultando em uma competição entre o nitreto de cromo e a precipitação da austenita. A microestrutura formada durante o resfriamento rápido é composta de grãos grandes de ferrita com baixa fração volumétrica de austenita Widmanstätten e abundantes nitretos intragranulares ( $\mathrm{Cr}_{2} \mathrm{~N}$ em forma de barras ou forma tetragonal e placas de $\mathrm{CrN}$ ), o tamanho de dos precipitados tende a aumentar com a velocidades de resfriamento lentas ${ }^{53}$. 


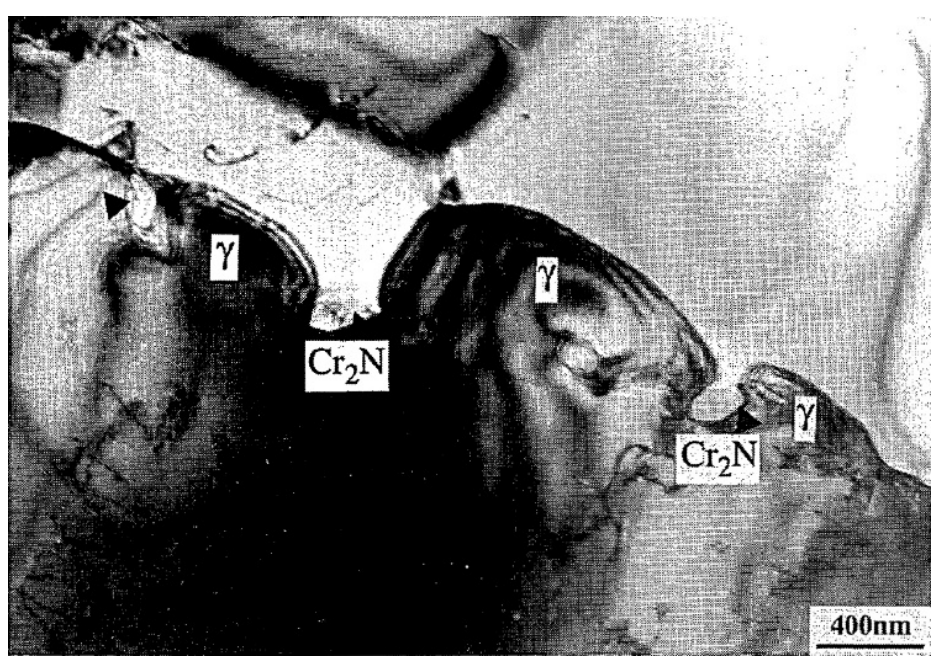

Figura 3-15. Imagem por MET de $\mathrm{Cr}_{2} \mathrm{~N}$ intergranular e a austenita secundária formados em SAF 2507 após envelhecimento durante $10 \mathrm{~min}$ a $850^{\circ} \mathrm{C}{ }^{17}$.

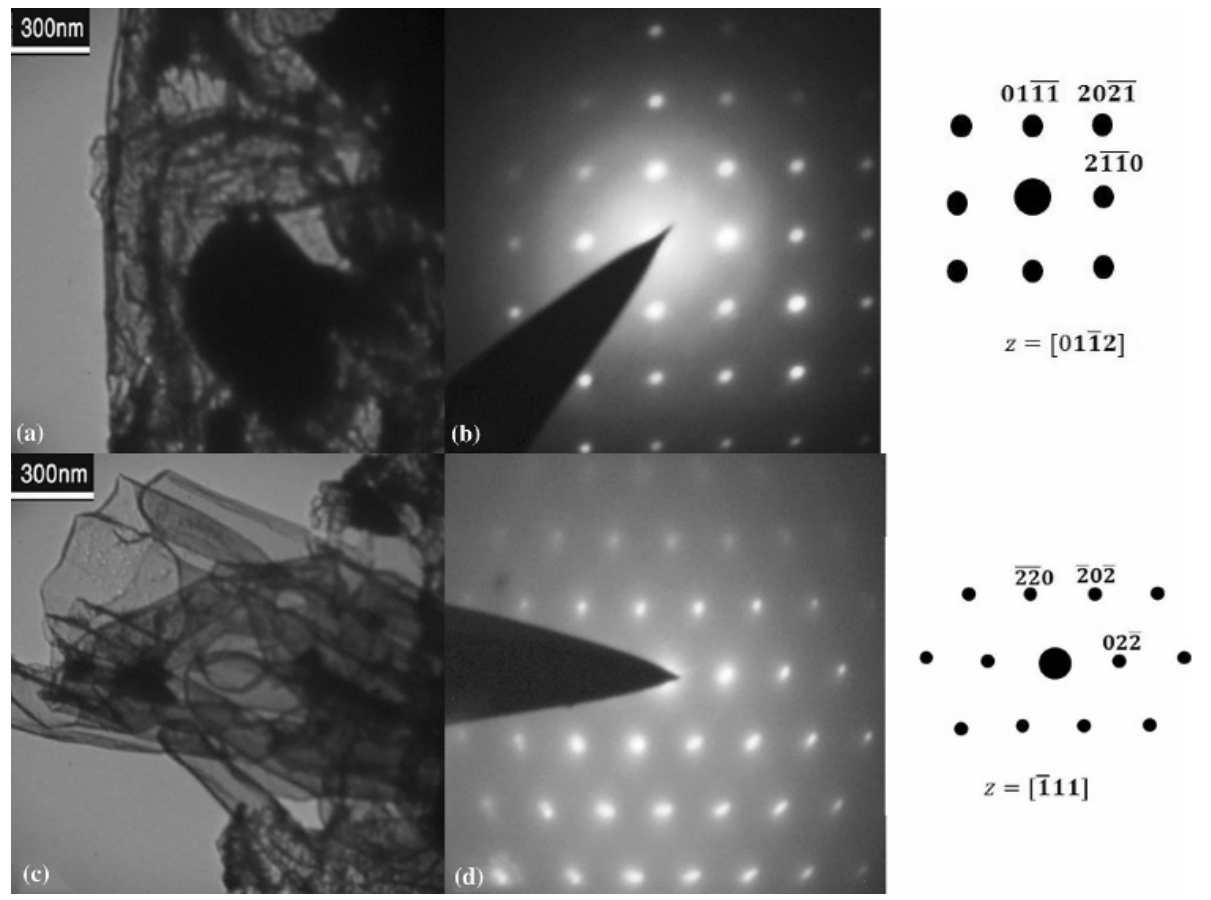

Figura 3-16. Imagem por MET de (a) $\mathrm{Cr}_{2} \mathrm{~N}$ (hexagonal) e (c) $\mathrm{CrN}$ (cúbico); com os correspondentes padrões de difração e índices dos planos: (b) $\mathrm{Cr}_{2} \mathrm{~N}$ e (d) $\mathrm{CrN}^{9}$.

Para o aço SAF 2205 a presença do CrN foi observada na ZTA porém nenhum efeito adverso nas propriedades como tenacidade ou corrosão foram observados ${ }^{17}$. Em geral a precipitação das fases $\mathrm{CrN} \mathrm{e} \mathrm{Cr}_{2} \mathrm{~N}$ resulta em redução de tenacidade e resistência à corrosão dos AIDs ${ }^{9}$. Os dois tipos de precipitados de nitretos de cromo observados na ZTA simulada do AID 2205 com $\Delta t_{8 / 5}$ (tempo de resfriamento de 800 a $500^{\circ} \mathrm{C}$ ) de 20 e $120 \mathrm{~s}^{53}$. Na Figura 3-17 (a) foi 
identificado o $\mathrm{Cr}_{2} \mathrm{~N}$ de forma tetragonal, e na Figura 3-17 (b) o precipitado de $\mathrm{CrN}$ em forma de plaquinhas com os respectivos padrões de difração. Na Figura 3-17 (c) mostra uma grande quantidade de precipitados de $\mathrm{CrN}$ e $\mathrm{Cr}_{2} \mathrm{~N}$ na matriz ferrítica formada com $\Delta t_{8 / 5}$ de 20 s e $120 \mathrm{~s}$, com o incremento do $\Delta t_{8 / 5}$ os nitretos são escassos e isso pode estar relacionado com a reformação da austenita a uma taxa de resfriamento mais lenta $9 ; 59$.

(a)
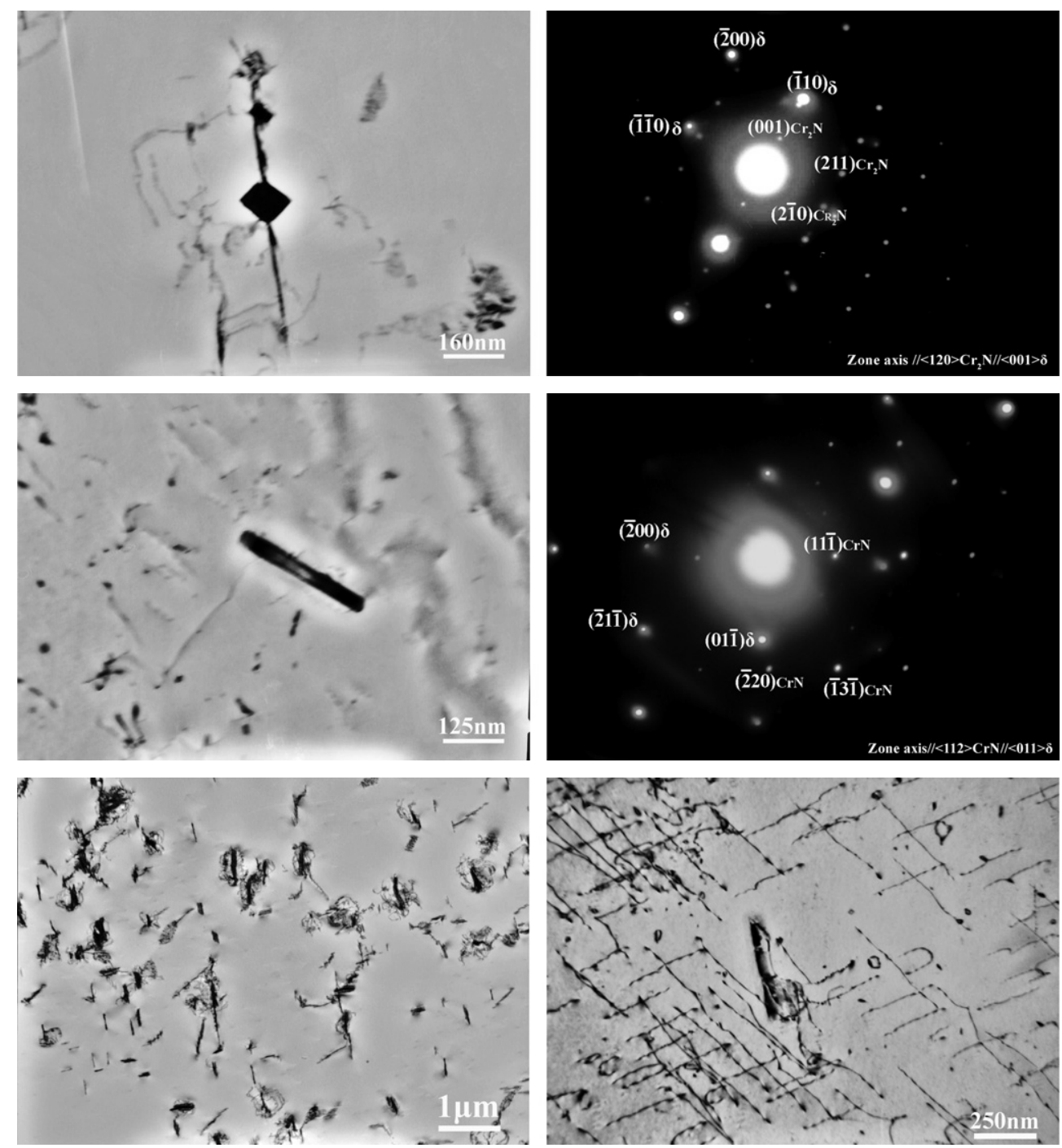

Figura 3-17. Imagem por TEM de ZTA do aço 2205. (a) Precipitado de $\mathrm{Cr}_{2} \mathrm{~N}$ e padrão de difração (b) Pequenos precipitados em plaquinhas de $\mathrm{CrN}$ em padrão de difração (c) $\mathrm{CrN}$ e $\mathrm{Cr}_{2} \mathrm{~N}$ com $\Delta t_{3 / 5}=$ $20 \mathrm{~s}$ e morfologia da matriz com $\Delta t_{3 / 5}=120 \mathrm{~s}^{59}$.

A quantidade de aporte de calor é um fator importante na soldagem dos aços inoxidáveis e tem um efeito na razão das fases $\delta / \gamma$. Com os aportes de calor mais altos se obtém maior quantidade de austenita e fase $\sigma$. Quando os aportes de calor são baixos a quantidade de ferrita nas ZTAs se incrementa, e nestas 
condições de resfriamento rápido se precipitam os nitretos ricos em cromo e drasticamente é reduzida a resistência à corrosão e propriedades mecânicas 9 .

\subsection{3.}

\section{Austenita Secundária}

A decomposição da ferrita em austenita pode ocorrer para uma ampla faixa de temperatura. Isto ocorre porque a estrutura duplex é temperada a partir de uma temperatura mais elevada, na qual a fração volumétrica de equilíbrio da fase $\delta$ é maior. Três mecanismos são sugeridos para esta decomposição (além da transformação direta de ferrita em austenita $\delta \rightarrow \gamma$ que ocorre em temperaturas muito elevadas), pelo qual a austenita $\gamma$ pode precipitar em ferrita $\delta$ :

(i) pela reação eutetóide $\delta \rightarrow \sigma+\gamma$

(ii) como precipitados Widmanstätten

(iii) através de um processo de cisalhamento martensítico.

A reação eutectóide é facilitada pela difusão rápida ao longo dos contornos de fase $\delta / \gamma$ e muitas vezes resulta em uma estrutura eutectóide típica de fase $\sigma$ e austenita nos grãos de ferrita primaria (Figura 3-18). Ocorrendo tipicamente na faixa de temperatura de 700 até $900^{\circ} \mathrm{C}$. Nesta faixa de temperatura $\delta$ é desestabilizada pela precipitação da fase $\sigma$, reduzindo o teor de cromo e molibdênio na ferrita ${ }^{17}$.

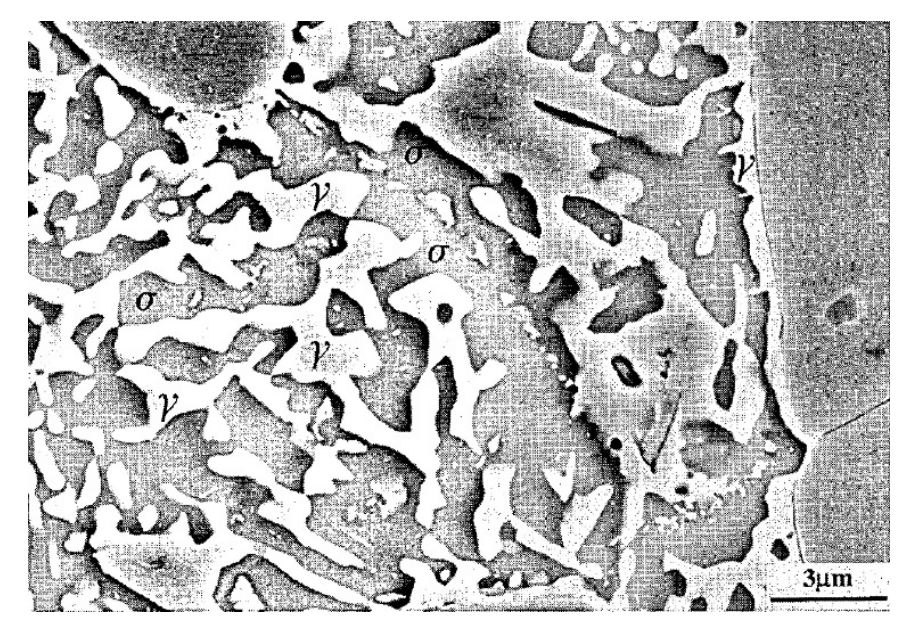

Figura 3-18. Imagem por MEV do SAF 2507 envelhecido durante 72 horas a $700^{\circ} \mathrm{C}$ mostrando a decomposição da ferrita dentro da estrutura eutectóide de fase $\sigma$ e austenita secundária ${ }^{17}$. 
Para temperaturas abaixo de $650^{\circ} \mathrm{C}$, um AID experimental apresentou um mecanismo de transformação $\delta \rightarrow \gamma$, similar a transformação martensítica. A austenita precipitada isotérmicamente não mostra diferença em composição quando comparada com a ferrita, indicando que a transformação foi menos difusiva com respeito aos elementos substitucionais. A relação de orientação encontrada obedece a relação de Nishiyama-Wasserman ${ }^{17}$.

Para temperaturas superiores a $650^{\circ} \mathrm{C}$, onde a difusão dos átomos é mais rápida, a austenita Widmanstätten formada precipita com diferentes morfologias. Essa austenita obedece a relação de Kurdjumov-Sachs e apresenta um teor de níquel significativamente maior do que a ferrita circundante, indicando que a transformação foi por difusão, o que pode ser indiretamente confirmado pela cinética da gráfico TTT ${ }^{17}$.

A austenita secundária formada nos contornos de fases $\delta / \gamma$ apresenta baixo teor de cromo, particularmente quando o $\mathrm{Cr}_{2} \mathrm{~N}$ precipita ao mesmo tempo. Isto pode explicar por que o ataque por pites pode ocorrer nestas áreas e também porque algumas vezes os pites são um problema, embora a quantidade de fase $\sigma$ seja considerada insignificante ${ }^{17}$.

\subsection{4.}

Fase $\chi$

A fase $\chi$ pertence ao sistema CFC e precipita como um composto ternário que contém Fe, Cr e Mo com uma ampla gama de estequiometria que se estende desde a fase $\chi$ ternária $\mathrm{Fe}_{36} \mathrm{Cr}_{12} \mathrm{Mo}_{10}{ }^{54}$ até sistemas quaternários como $\mathrm{Fe}-\mathrm{Cr}$ $\mathrm{Ni}-\mathrm{Mo}{ }^{53}, \mathrm{Fe}-\mathrm{Cr}-\mathrm{Ni}-\mathrm{Ti}^{53}$ e $\mathrm{Fe}_{36} \mathrm{Cr}_{12} \mathrm{Mo}_{3} \mathrm{Ti}_{7}{ }^{54}$. A fase $\chi$ e a fase $\sigma$ geralmente são encontrada simultaneamente ${ }^{54}$. Embora em comparação com a fase $\sigma$, a fase $\chi$ é mais rica em molibdênio e mais pobre em cromo do que a fase $\sigma{ }^{53}$. A precipitação dessas fases causa na matriz um empobrecimento de elementos de liga como cromo. molibdênio e nióbio que lidera o deterioração da tenacidade e a resistência à corrosão nos AIDs ${ }^{54}$.

Embora, a fase intermetálica $\chi$ seja comumente encontrada nos AIDs na faixa de temperatura entre 700 e $900^{\circ} \mathrm{C}$, geralmente está presente em quantidades menores do que a fase $\sigma^{17} 7$. A região de máxima velocidade de transformação "nariz" no diagrama de transformação isotérmica (gráfico TTT: transformação-tempo-temperatura) usualmente aparece a temperaturas mais baixas. Por exemplo, no aço SAF 2507 , essa temperatura foi de $850^{\circ} \mathrm{C}$, que é 
cerca de $75^{\circ} \mathrm{C}$ mais baixa do que o descrito para a precipitação da fase $\sigma$ na mesma liga (Figura 3-19) 17.

A fase $\chi$ parece ter um efeito adverso na tenacidade e na resistência à corrosão, mas é difícil separar o efeito de cada uma das fases uma vez que são coexistentes ${ }^{1754}$. De um modo geral a fração volumétrica da fase $\chi$ é menor do que a fase $\sigma$, no entanto o efeito da fase $\chi$ não pode ser ignorado ${ }^{17}$. Por exemplo, na Figura 3-19 na seção inferior do gráfico TTT da fase $\sigma$ para o aço SAF 2507, as temperaturas da corrosão por pites podem ser baixas, embora virtualmente não exista a fase $\sigma$. A precipitação da fase $\chi$ é em parte responsável por isso, porque consome cromo e molibdênio e a austenita secundária formada simultaneamente torna-se pobre nesses elementos ${ }^{17}$.

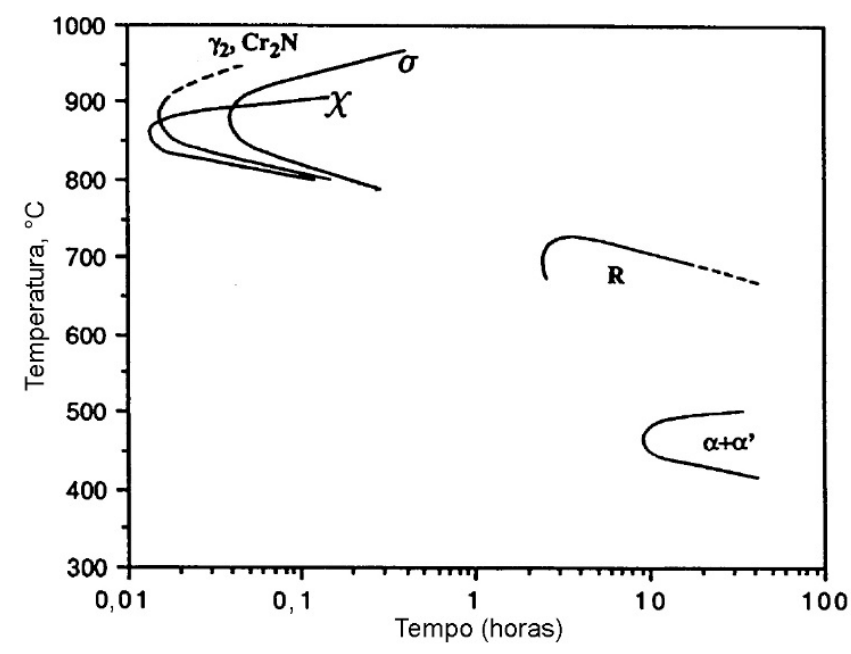

Figura 3-19. Gráfico TTT para vários precipitados no aço SAF $2507{ }^{17}$.

A fase $\chi$ nucleia principalmente nas interfaces ferrita / austenita e além nas interfaces ferrita / ferrita. É estável a temperaturas mais baixas em uma faixa de temperatura mais estreita $\left(900-600^{\circ} \mathrm{C}\right)$ do que a fase $\sigma$, mas a fase $\chi$ se transforma em fase $\sigma$ depois de um longo tempo de envelhecimento ${ }^{53}$.

A fase $\chi$ pode ser identificada usando difração de elétrons no MET quanto por MEV usando elétrons retroespalhados. Devido ao maior teor de molibdênio presente na fase, cerca de $20 \%$, em combinação com o grande fator de dispersão atômica do molibdênio, a fase $\chi$ apresenta um contraste maior do que aquele apresentado pela fase $\sigma$. Isso é mostrado na Figura 3-20 ${ }^{17}$. 


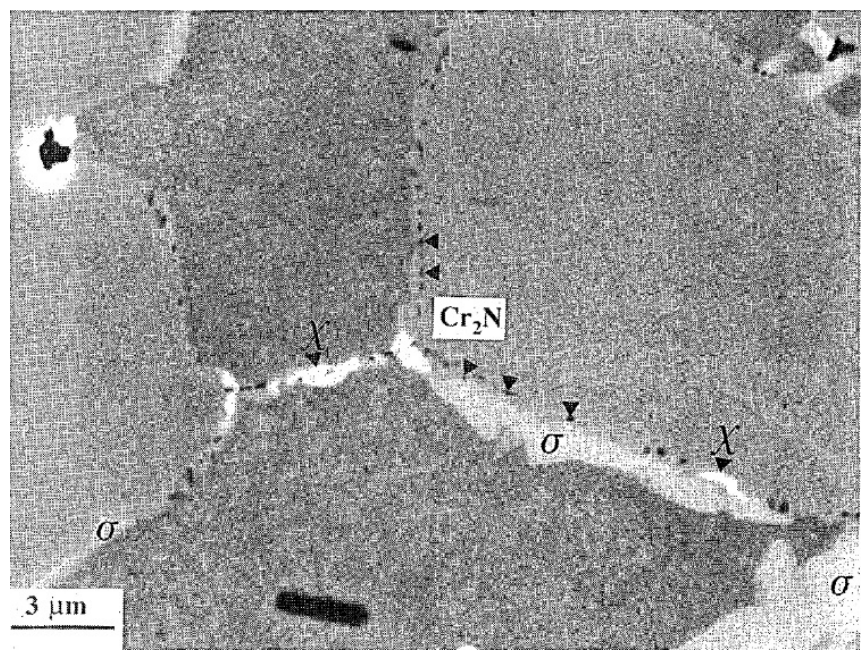

Figura 3-20. Micrografia de BSE da superfície polida de aço SAF 2507 envelhecido por 10 min a $850^{\circ} \mathrm{C}$, que mostra o contraste do número atômico: As partículas em contraste brilhante são a fase $\chi$, e as partículas com contraste mais escuro são a fase $\sigma^{17}$.

\subsection{5.}

\section{Fase $R$}

A fase $R$ foi reportada por Hochmann ${ }^{60}$ e precipita nos AIDs na faixa de 550 a $700^{\circ} \mathrm{C}$. Esta fase $R$ é um composto intermetálico rico em molibdênio e com estrutura cristalina trigonal. Como a fase $R$ foi identificada no aço SAF 2507, a sua presença é esperada nos aços da classe inoxidável super duplex. Foi observado que a tenacidade e a temperatura crítica de corrosão por pites são reduzidas em presença da fase $R$, a qual apresenta duas formas de precipitação inter e intragranular. É sugerido que os precipitados intergranulares possam ser mais deletérios em relação à corrosão por pites porque podem conter até $40 \%$ de molibdênio. Para o MS $22 \mathrm{Cr}-8 \mathrm{Ni}-3 \mathrm{Mo}$ a fase $R$ possui $30 \% \mathrm{Fe}, 25 \% \mathrm{Cr}, 6 \% \mathrm{Ni}$, $35 \% \mathrm{Mo} \mathrm{e} 4 \% \mathrm{Si}$. A identificação da fase $R$ por MET (Figuras 2-21 e 2-22) mostra contraste desigual. No entanto esse critério não é suficiente para a identificação, e deve ser complementado com uma análise por difração de elétrons ${ }^{17}$. A quantidade de fase $R$ tende a ser pouca e isso dificulta que seja detectada e geralmente seu efeito é atribuído à fase $\sigma^{60}$. 


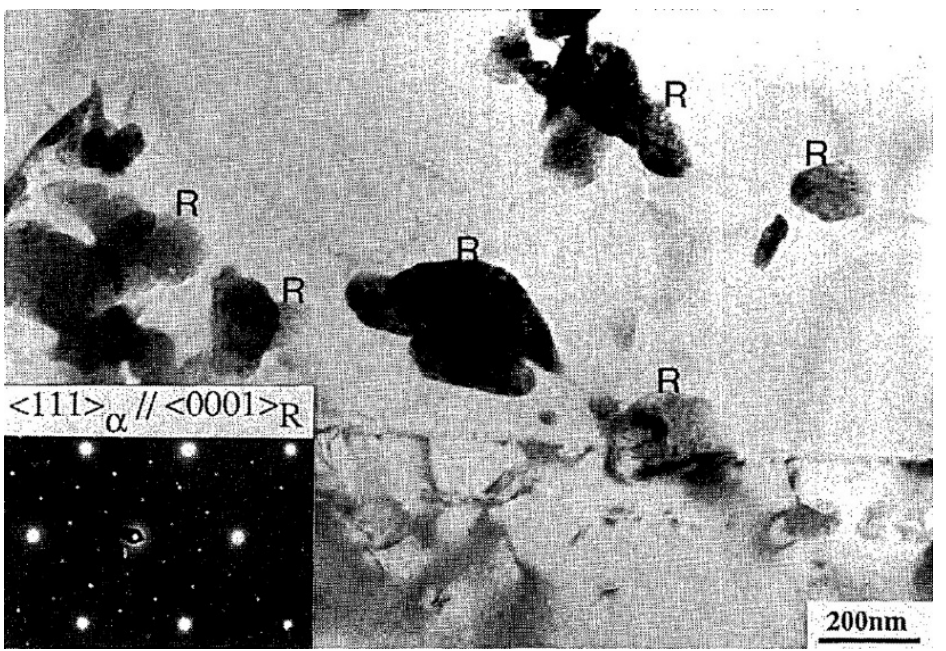

Figura 3-21. Imagem por MET do MS 22Cr-8Ni-3Mo envelhecido por 24 horas a $600^{\circ} \mathrm{C}$. Os precipitados da fase $R$ apresentam contraste desigual e a relação de orientação com os grãos ferríticos é $<0001>R$ II $<111>\delta$ como amostrado no padrão de difração ${ }^{17}$.
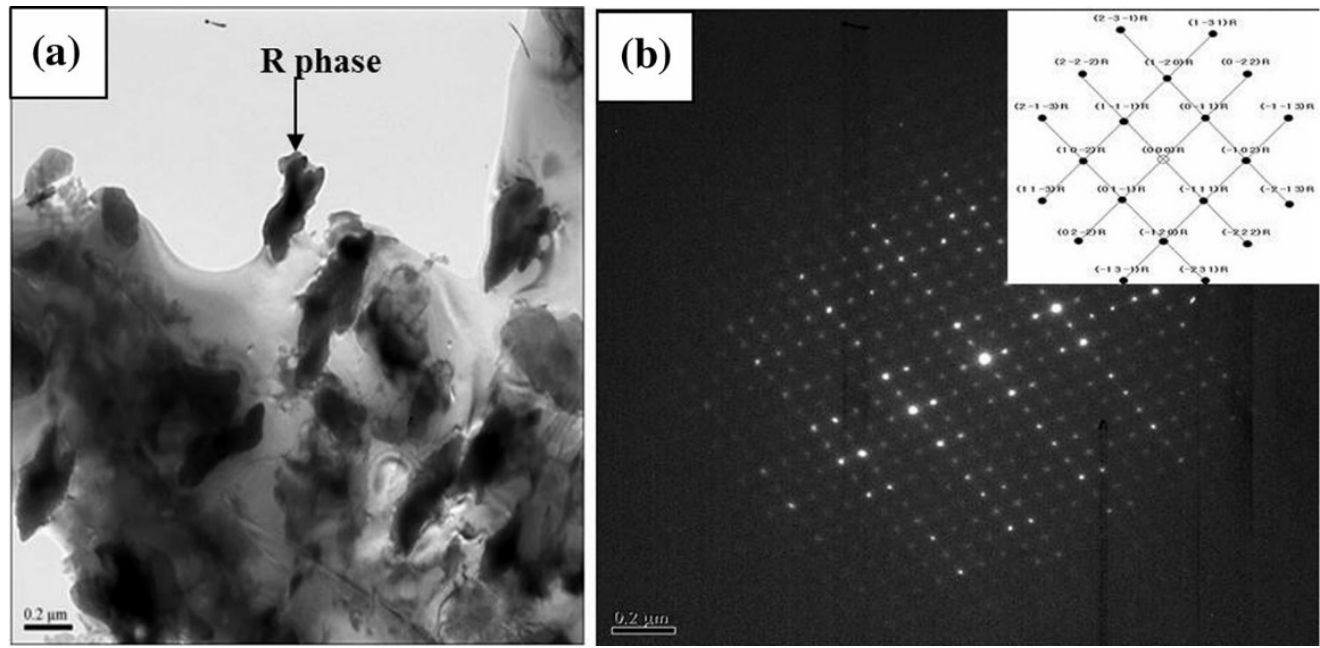

Figura 3-22. Imagem por TEM da fase $R$ precipitada dentro da fase ferrítica do aço super duplex após do tratamento térmico de envelhecimento e solubilização. (a) Imagem de campo claro e (b) padrão de difração e índice do plano (241) ${ }^{60}$.

\subsection{6.}

Fase $\pi$

Em contraste à fase $R$, a fase $\pi$ tem a estrutura cristalina cúbica e apresenta um contraste uniforme no MET, como mostrado na Figura 3-23. Essa fase se precipita dentro dos grãos e como a fase $R$, contribui à fissuração e à corrosão por pites no material envelhecido isotermicamente a $600^{\circ} \mathrm{C}$. 
No MS do duplex 22Cr-8Ni-3Mo.a fase $\pi$ de nitreto foi encontrada com uma composição aproximada de $28 \% \mathrm{Fe}, 35 \% \mathrm{Cr}$, 3\% $\mathrm{Ni}$ e $34 \% \mathrm{Mo}$, isso mostra que a fórmula química ideal proposta $\mathrm{Fe}_{7} \mathrm{Mo}_{13} \mathrm{~N}_{4}$ é só uma aproximação grosseira ${ }^{17}$.

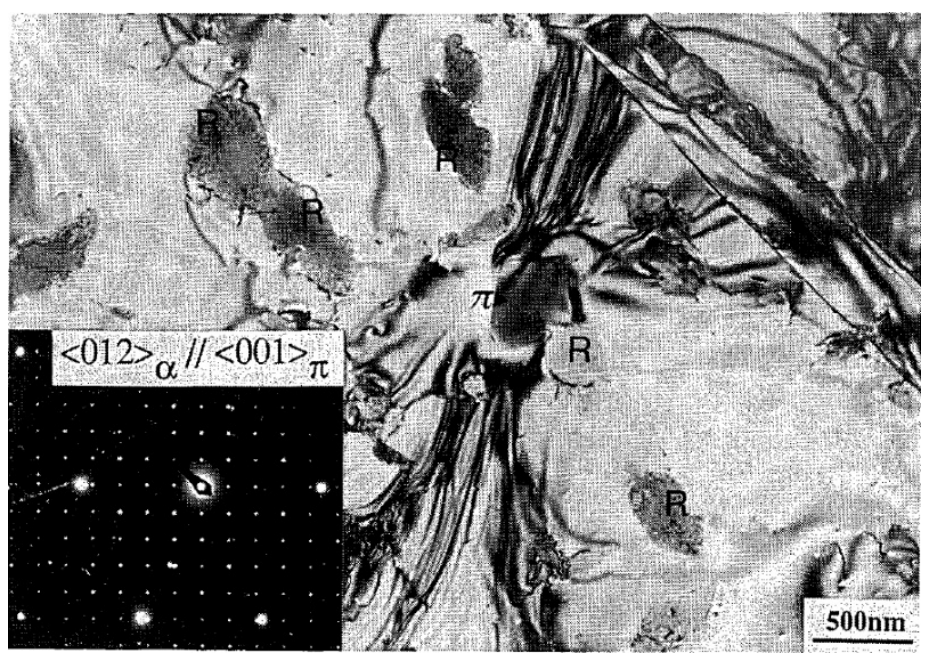

Figura 3-23. Imagem por MET do $22 \mathrm{Cr}-8 \mathrm{Ni}-3 \mathrm{Mo}$, envelhecido por 24 horas a $600^{\circ} \mathrm{C}$ mostrando a fase $\pi$ com contraste homogêneo no grão de ferrita. A relação de orientação é $<001>\pi$ II $<012>\delta$ 17

\subsection{7. \\ Carbonetos}

Nos carbonetos $M_{7} C_{3}$, a letra $M$ representa o elemento metálico, geralmente ferro e cromo ${ }^{61}$. Nos AIDs relativamente ricos e carbono, os carbonetos do tipo $\mathrm{M}_{7} \mathrm{C}_{3}$ precipitam na faixa de $950-1050^{\circ} \mathrm{C}$, enquanto que os carbonetos $\mathrm{M}_{23} \mathrm{C}_{6}$ precipitam abaixo de $950^{\circ} \mathrm{C}$. Os dois tipos de carbonetos são observados predominantemente nos contornos de fase $\delta / \gamma$, embora a precipitação nos contornos $\delta / \delta$ e $\gamma / \gamma$ também tenham sido observados. Os carbonetos têm uma função menos importante nos aços super duplex do que nos AIDs tradicionais em função do teor de baixo carbono, geralmente na faixa de $0,010-0,020 \%{ }^{17}$.

\subsection{8.}

\section{Fases Pouco Comuns}

Embora partículas de cobre tenham sido observadas em AIDs ricos em cobre, essas observações tem sido consideradas um tanto ambíguas. Isto ocorre porque tanto o cobre como a austenita possuem estruturas CFC e exibem a relação Kurdjumov-Sachs. Algumas partículas de cobre foram observadas 
utilizando amostras na forma de folhas finas retiradas de AIDs com 3\% Cu usando EDX em um MET analítico. É sugerido que es estas partículas de cobre promovem a nucleação da austenita, com um maior refinamento. Os precipitados ricos em cobre também tem sido observados em rolamentos de aços super duplex.

Outra fase incomum em AIDs é a fase $\tau$, que foi descoberta na liga $22 \mathrm{Cr}$ 5Ni-3Mo. Embora seus efeitos nas propriedades dos materiais não foram extensivamente pesquisados ${ }^{17}$.

\section{6.}

\section{Simulador Termo-Mecânico Gleeble}

Em 1957 o primeiro simulador Gleeble comercial foi produzido com a finalidade de estudos de soldabilidade. Os simuladores termo-mecânicos dinâmicos mais recentes permitem o uso de técnicas de simulação física, não só para a soldagem, mas também para outros processos de aplicação industrial ${ }^{62}$. As microestruturas obtidas geralmente mostram variações nas características e nas propriedades similares ao processo que se deseja simular. A simulação é realizada a partir da entrada de dados no sistema computacional da Gleeble e através do qual são executados testes a alta temperatura nos quais a solidificação e resfriamento são controlados ${ }^{63}$.

De um modo geral a ZTA é a região da junta soldada que pode ser vulnerável à fissuração e ao trincamento. Durante a ação do arco elétrico o ciclo térmico produz um rápido aquecimento até atingir a temperatura de pico, a qual é seguida de resfriamento devido ao fluxo de calor da zona quente em direção a região do material que se encontra mais fria 62 .

Durante o ciclo térmico, a corrente elétrica flui através da ZTA e o calor flui desde a superfície de fusão entre o MS e o MB da placa para formar planos isotérmicos perpendiculares à direção principal do fluxo de calor (Figura 3-24) ${ }^{62}$.

Durante o ciclo térmico de soldagem, uma parte do material da ZTA se expande pelo aquecimento e ao mesmo tempo sofre compressão no sentido transversal pelas porções ainda frias do $\mathrm{MB}$, enquanto que na segunda parte deste ciclo o resfriamento é mais rápido nas áreas de gradiente térmico, mais uma vez se comprime. Nesta segunda parte do ciclo térmico as deformações por tensão (tensile strains) também aparecem, em particular na direção principal do fluxo de calor, e estas podem ajudar à fragilização desta área devido à geração de discordâncias e da interação destas com átomos intersticiais, ou até iniciar fissuração intergranular ${ }^{62}$. 


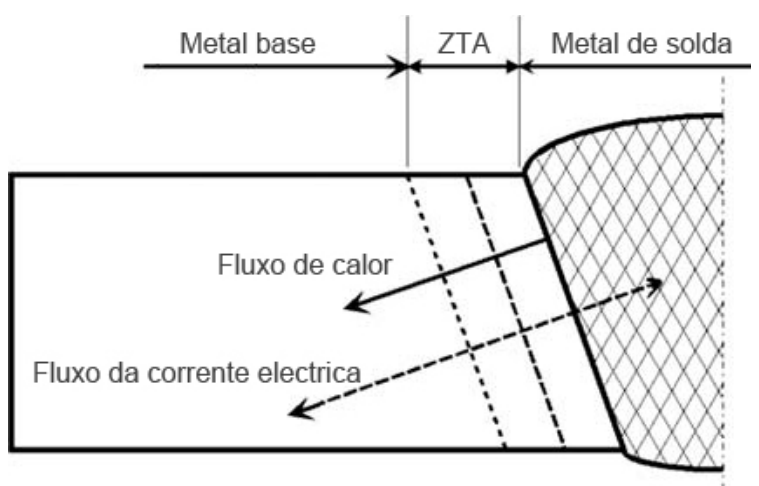

Figura 3-24. Simulação da ZTA em uma solda de arco com o fluxo de corrente eléctrica e o fluxo de calor ${ }^{62}$.

A simulação física realizada no simulador Gleeble permite obter regiões características maiores do que aquelas obtidas durante o processamento real, como por exemplo a ZTA. E por tanto se torna mais fácil visualizar e realizar testes mecânicos, analisar a relação entre a evolução da microestrutura e as propriedades mecânicas das ZTAs ${ }^{64}$.

O simulador fornece informação importante que não pode ser obtida a partir da soldagem real, onde variações microestruturais em dimensões micrométricas podem ocorrer dentro da ZTA. O simulador é portanto usado para criar as regiões da ZTA com dimensões mais amplas de modo a permitir realizar testes mecânicos e caraterização metalográfica de modo a entender os fundamentos da evolução microestrutural durante a soldagem ${ }^{64}$.

Para se realizar a simulação na Gleeble é necessário calcular os ciclos térmicos e definir o modelo de transferência de calor. A unidade de simulação possui atmosfera controlada (Figura 3-25) e o ciclo térmico é controlado por um software o qual recebe informações através de um termopar soldado à superfície do corpo de prova 65 .

O sistema de aquecimento por efeito Joule pode atingir velocidades de até $20.000^{\circ} \mathrm{C} / \mathrm{s}$. O resfriamento do corpo de prova é realizado por condução de peças de cobre que posicionam a amostra e são refrigeradas permitindo velocidades de resfriamento de até $100^{\circ} \mathrm{C} / \mathrm{s}^{65}$. 


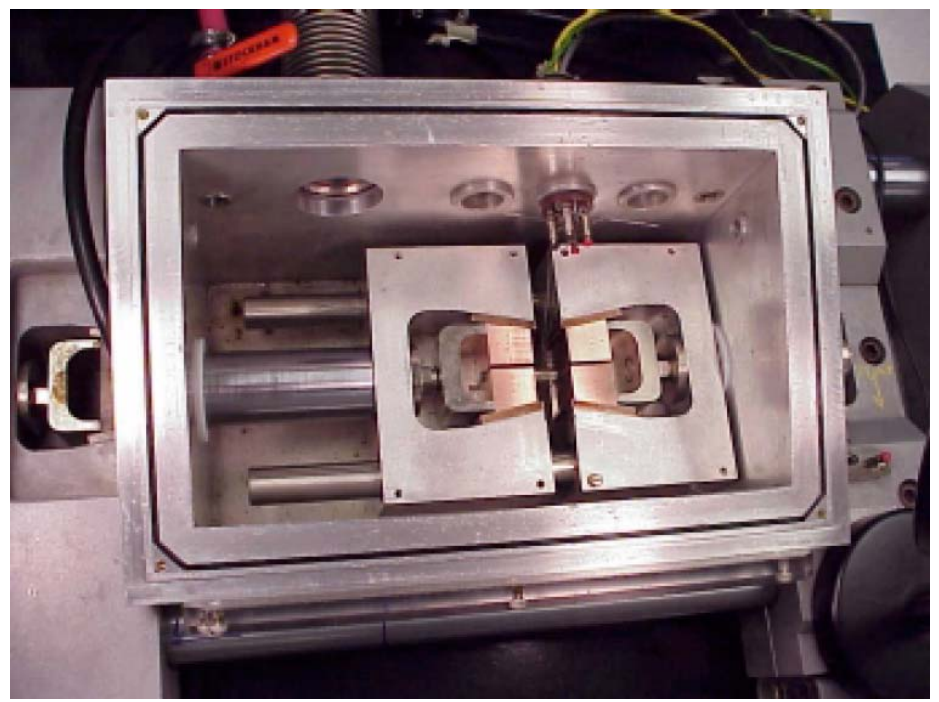

Figura 3-25. Vista superior da unidade de simulação do equipamento Gleeble 1500 com a câmara de vácuo.

Na Figura 3-26 é mostrado o detalhe da montagem do corpo de prova no sistema. Nesta mesma figura é possível visualizar o gradiente térmico gerado no corpo de prova durante a simulação ${ }^{65}$.

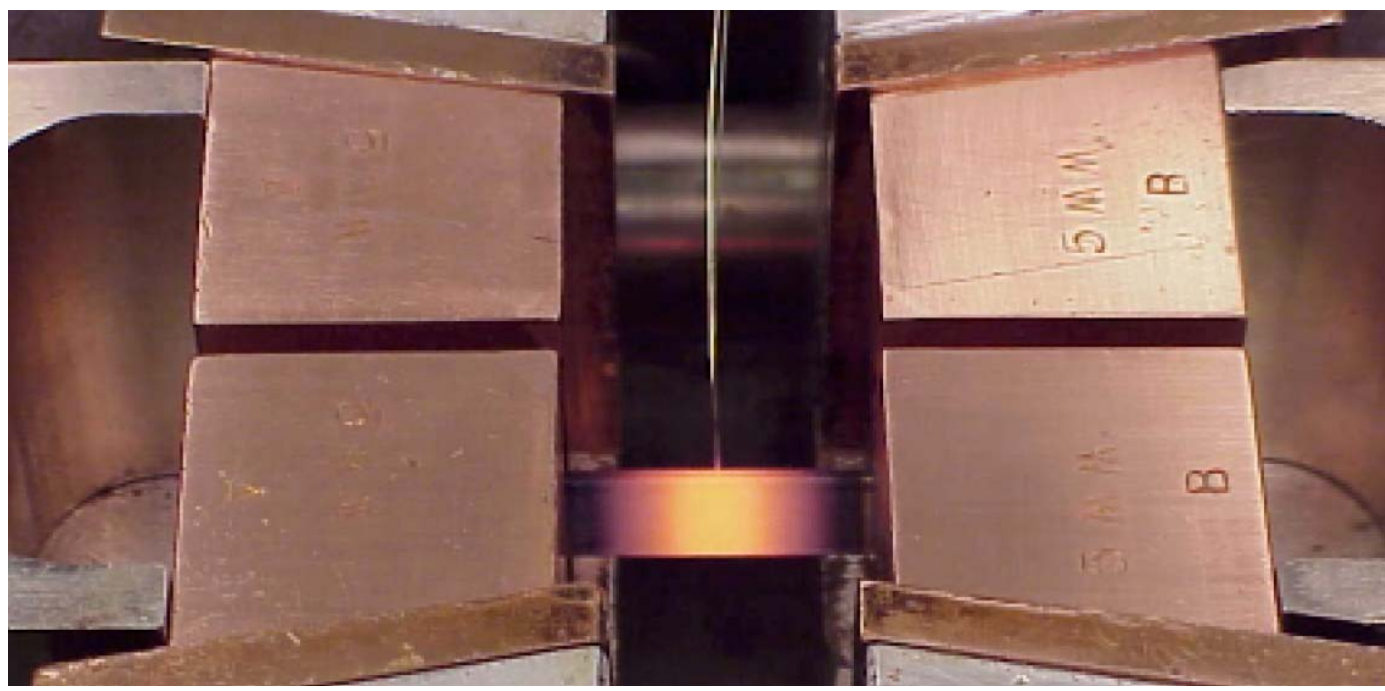

Figura 3-26. Detalhe da montagem do corpo de prova na unidade de simulação do equipamento Gleeble 1500.

Em algumas pesquisas com aços duplex se aplicaram ciclos térmicos que simulam a microestrutura da ZTA na condição como soldado, o recozimento de ferritização é realizado a temperaturas próximas a $1390^{\circ} \mathrm{C}$ onde ocorre a transformação completa da austenita para ferrita (Figura 3-27) 39666759. 

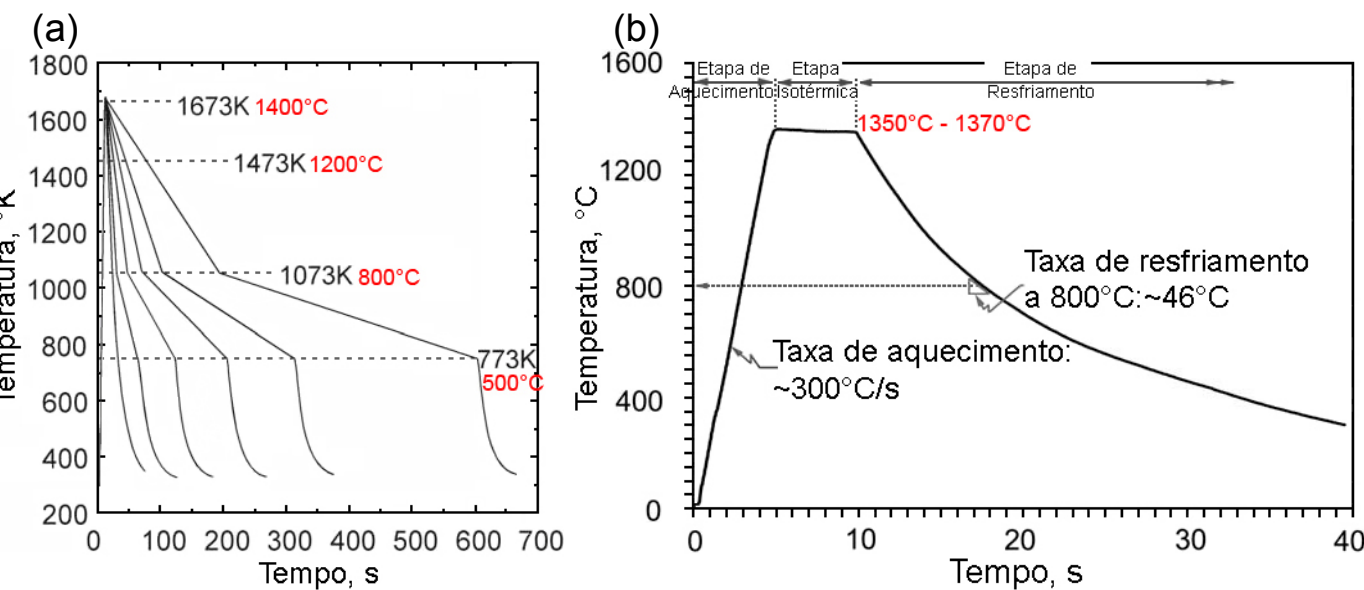

Figura 3-27. Ciclo térmico de ferritização simulado aplicado por (a) Kuroda e por (b) Garzón.

O tratamento de ferritização aplicado nessas pesquisas consiste de um ciclo térmico com uma etapa mantida à temperatura de pico de $1345-1400^{\circ} \mathrm{C}$ durante aproximadamente 5 segundos, seguido por uma etapa de resfriamento rápido. A média de velocidade de aquecimento aplicada é de $140-350^{\circ} \mathrm{C} / \mathrm{s}$ e são utilizadas diferentes velocidades de resfriamento até atingir $800^{\circ} \mathrm{C}$

A história térmica da simulação está embasada na função de temperatura / tempo calculada por Limbdlom (Equação 3-9) 6639 59:

$$
\frac{\Delta t_{8 / 5}}{\Delta t_{12 / 8}}=\frac{\frac{1}{\left(500-T_{0}\right)^{2}}-\frac{1}{\left(800-T_{0}\right)^{2}}}{\frac{1}{\left(800-T_{0}\right)^{2}}-\frac{1}{\left(1200-T_{0}\right)^{2}}}
$$

Onde:

$T_{o}$ é a temperatura de início $\left[{ }^{\circ} \mathrm{C}\right]$

$\Delta t_{8 / 5}$ é o tempo de resfriamento de 800 a $500^{\circ} \mathrm{C}[\mathrm{s}]$

$\Delta t_{1 / 8}$ é o tempo de resfriamento de 800 a $500^{\circ} \mathrm{C}$ [s]

O parâmetro de soldagem $\Delta t_{8 / 5}$ é aplicável mais comumente para os aços ao carbono e aços de baixa liga. Para os AIDs, o uso de $\Delta t_{12 / 8}$ tem sido sugerido pela formação e precipitação da austenita ocorre nesta faixa de temperatura, e a Equação 3-9 estabelece uma relação entre os dois tempos de resfriamento $\Delta t_{8 / 5}$ e $\Delta t_{12 / 8}{ }^{59}$.

Para relacionar os aportes de calor com o $\Delta t_{8 / 5}$ se aplica a seguinte relação 39666759 : 
$\frac{Q}{d}=k\left(\Delta t_{8 / 5}\right)^{1 / 2}$

Equação 3-10

Onde:

$Q$ é o aporte de calor líquido, [J/mm] $d$ é a espessura do corpo de prova, $[\mathrm{mm}]$

$k$ é o coeficiente térmico dos AIDs, $\left[\mathrm{J} / \mathrm{mm}^{2} \mathrm{~s}^{1 / 2}\right]$

Os aportes de calor aplicados em pesquisas de AIDs são variados, algumas pesquisas usam baixos aportes de calor entre $0,57-2,55 \mathrm{~kJ} / \mathrm{mm}$ e outras aportes maiores de 1 - $6 \mathrm{~kJ} / \mathrm{mm}^{39}{ }^{66}$. O aporte de calor deve ser suficiente para permitir uma razoável formação da austenita na ZTA. Um mínimo de 0,2 - 0,5 kJ/mm é geralmente solicitado quando se usa soldagem a arco elétrico dependendo do grau e espessura do aço ${ }^{56}$. 


\section{4}

\section{Materiais e Métodos}

O objetivo deste estudo foi avaliar as propriedades associadas às ZTAs dos três aços UNS S32304, S32205 e S32750 quando obtidas por simulação física na Gleeble 3800 com diferentes aportes de calor entre $1,0 \mathrm{~kJ} / \mathrm{mm}$ e $3,0 \mathrm{~kJ} / \mathrm{mm}$, visando comparar as evoluções microestruturais e comportamento mecânico das ZTAs com os diferentes aportes de calor programados. Este capítulo apresenta a metodologia a qual inclui a utilização do software Thermo-Calc, a simulação física das ZTAs nos três aços em estudo e os procedimentos adotados na caracterização microestrutural e mecânica das ZTAs simuladas.

\section{1.}

\section{Materiais}

O materiais estudados foram os AIDs UNS S32304, S32205 e S32750. Os três aços foram laminados durante o processo de fabricação. O aço inoxidável lean duplex S32304 foi fornecido em forma de chapa com 8,5 mm de espessura. No caso dos aços duplex e super duplex S32205 e S32750, respectivamente, foram fornecidos em forma de tubo sem costura fabricados de acordo com a norma ASTM A790 ${ }^{68}$, com 8,15 mm de espessura e 8 polegadas de diâmetro externo. As composições químicas dos três aços são descritas na Tabela 4-1 segundo a norma ASTM A240-15 ${ }^{69}$ e na Tabela 4-2 segundo as especificações dos fabricantes Aperam (S32304) e Sandvik (S32205 e S32750).

Tabela 4-1. Composição química dos aços estudados, segundo a norma ASTM A240-15 ${ }^{69}$, porcentagem em massa (\%).

\begin{tabular}{|c|c|c|c|c|c|c|c|c|c|c|}
\hline Elemento & $\mathbf{C}$ & $\mathbf{C r}$ & $\mathbf{N i}$ & $\mathbf{M o}$ & $\mathbf{M n}$ & $\mathbf{P}$ & $\mathbf{S}$ & $\mathbf{S i}$ & $\mathbf{C u}$ & $\mathbf{N}$ \\
\hline $\begin{array}{c}\mathbf{S 3 2 3 0 4} \\
\mathbf{2 3 0 4}\end{array}$ & $\leq 0,030$ & $21,5-24,5$ & $3,0-5,5$ & $0,05-0,60$ & $\leq 2,5$ & $\leq 0,040$ & $\leq 0,030$ & $\leq 1,00$ & $0,05-0,60$ & $0,05-0,20$ \\
\hline $\begin{array}{c}\text { S32205 } \\
\text { (SAF 2205) }\end{array}$ & $\leq 0,030$ & $22,0-23,0$ & $4,5-6,5$ & $3,0-3,5$ & $\leq 2,0$ & $\leq 0,030$ & $\leq 0,020$ & $\leq 1,00$ & - & $0,14-0,20$ \\
\hline $\begin{array}{c}\text { S32750 } \\
\text { (SAF 2507) }\end{array}$ & $\leq 0,030$ & $24,0-26,0$ & $6,0-8,0$ & $3,0-5,0$ & $\leq 1,2$ & $\leq 0,035$ & $\leq 0,020$ & $\leq 0,90$ & 0,50 & $0,24-0,32$ \\
\hline
\end{tabular}


Tabela 4-2. Composição química dos aços estudados, segundo as folhas de dados da Aperam e Sandvik, porcentagem em massa (\%).

\begin{tabular}{|c|c|c|c|c|c|c|c|c|c|c|}
\hline Elemento & $\mathbf{C}$ & $\mathbf{C r}$ & $\mathbf{N i}$ & $\mathbf{M o}$ & $\mathbf{M n}$ & $\mathbf{P}$ & $\mathbf{S}$ & $\mathbf{S i}$ & $\mathbf{C u}$ & $\mathbf{N}$ \\
\hline $\begin{array}{c}\mathbf{S 3 2 3 0 4} \\
\mathbf{( 2 3 0 4 )}\end{array}$ & $\leq 0,030$ & 22,5 & 4,5 & 0,3 & $\leq 2,0$ & $\leq 0,035$ & $\leq 0,015$ & $\leq 1,0$ & 0,3 & 0,1 \\
\hline $\begin{array}{c}\text { S32205 } \\
\text { (SAF 2205) }\end{array}$ & $\leq 0,030$ & 22 & 5 & 3,2 & $\leq 2,0$ & $\leq 0,030$ & $\leq 0,015$ & $\leq 1,0$ & - & 0,18 \\
\hline $\begin{array}{c}\text { S32750 } \\
\text { (SAF 2507) }\end{array}$ & $\leq 0,030$ & 25 & 7 & 4 & $\leq 1,2$ & $\leq 0,035$ & $\leq 0,015$ & $\leq 0,8$ & - & 0,3 \\
\hline
\end{tabular}

\subsection{1.}

\section{Processos de Fabricação}

O aço lean duplex $\$ 32304$ fornecido na forma de chapa foi fabricado pela Aperam. O processo de fabricação informado pelo fabricante foi o seguinte.

Considerando que os aços de maior resistência, também são resistentes à laminação, necessitam na fase de desbaste da placa de uma pré laminação, ou seja uma redução parcial na espessura com o objetivo de evitar trincas de borda e defeitos superficiais além de diminuição nas cargas de laminação.

O fluxo de produção da chapa S32304 foi:

- Pré laminação no laminador Rougher em 4 passes na temperatura de $1100^{\circ} \mathrm{C}$, de $200 \mathrm{~mm}$ para $154 \mathrm{~mm}$.

- A placa retorna para o forno onde é reaquecida e novamente é laminada no Rougher em 7 passes a $1100^{\circ} \mathrm{C}, 154 \mathrm{~mm}$ para $28 \mathrm{~mm}$.

- Na sequência a tira continua sua laminação final no laminador Steckel em $1050^{\circ} \mathrm{C}$, de $28 \mathrm{~mm}$ para $9,5 \mathrm{~mm}$.

- Após esfriar a bobina é cortada em chapas e é feito o recozimento final em forno estático a $1070^{\circ} \mathrm{C}$ no encharque.

- O resfriamento se dá com spray de água e a chapa é decapada em banho químico.

Os processos de fabricação seguidos pela Sandvik para o aço duplex com designação S32205 e o aço super duplex S32750 foram de acordo à norma ASTM A790 68. A norma estabelece que os tubos deverão ser fornecidos na condição de tratado termicamente, em conformidade com os procedimentos apresentados na Tabela 4-3. Para tubos sem costura, como uma alternativa ao tratamento térmico final, num forno contínuo ou de carga (batch-type), imediatamente seguido por uma deformação a quente, enquanto que a temperatura dos tubos não seja menor do que a temperatura mínima do tratamento de solubilização, os tubos podem ser temperados individualmente em água ou resfriados rapidamente por outros meios 68. 
Tabela 4-3. Tratamentos térmicos dos tubos $\$ 32205$ e $\$ 32750$ durante o processo de fabricação de acordo com a norma ASTM A790 68.

\begin{tabular}{|c|c|c|}
\hline Designação UNS & Temperatura $\left[{ }^{\circ} \mathbf{C}\right]$ & Têmpera \\
\hline S32205 & $1020-1100$ & Resfriamento rápido em ar ou água \\
\hline S32750 & $1025-1125$ & Resfriamento rápido em ar ou água \\
\hline
\end{tabular}

\section{2.}

Métodos

\subsection{1.}

\section{Composição Química}

Com o objetivo de verificar a composição química dos AIDs em estudo foi realizada por análise química instrumental em duplicata, via espectroscopia de emissão ótica segundo a norma ASTM A751-11 ${ }^{70}$.

\subsection{2.}

\section{Simulação do Diagrama de Fase no Software Thermo-Calc}

Os diagramas de fases dos AIDs em estudo foram obtidos utilizando o software Thermo-Calc versão $4.1 \mathrm{com}$ a base de dados TCFE3 ${ }^{71}$. Nessas simulações foram usadas as composições químicas obtidas para cada aço no primeiro teste de composição química por espectroscopia de emissão ótica.

A base de dados TCFE3 é uma base de dados termodinâmica aplicável para diferentes tipos de aços e ligas de ferro com um mínimo de $50 \%$ de ferro em massa. É usada para prever as temperaturas de liquidus e solidus para diferentes tipos de aços. Além de prever as fases que se encontram em equilíbrio em estado sólido. A base de dados tem sido desenvolvida e validada para simulação de processos de solidificação, estabilidade de fases da matriz, precipitação de fases secundarias como sulfetos, boretos, óxidos, fosfetos, carbonetos, nitretos, carbonitretos além de fases intermetálicas tais como a fase sigma e a fase Laves 7172

\subsection{3.}

\section{Simulação Física da ZTA na Gleeble}

O software de programação para obtenção das ZTAs (HAZ Software) é um recurso do QuikSim ${ }^{T M}$ Software no ambiente de programação da Gleeble. Por 
meio deste software de programação pode-se simular a ZTA tanto para soldagens de um passe como para soldagens multipasses ${ }^{73} 74$.

Um dos recursos do HAZ Software é a possibilidade de utilização de pelos menos 6 configurações diferentes (Curve Type) para gerar as curvas de simulação da ZTA (aquecimento e resfriamento), o primeiro tipo de curva é uma tabela com os dados da curva (tempo, temperatura). As outras 5 configurações são modelos matemáticos de distribuição de calor associados aos ciclos térmicos de resfriamento que ocorrem durante um processo de soldagem real. Entre essas configurações está o tipo de curva Rykalin-2D, a qual foi desenvolvida com base no trabalho de N. N. Rykalin (Figura 4-1) ${ }^{73} 74$.

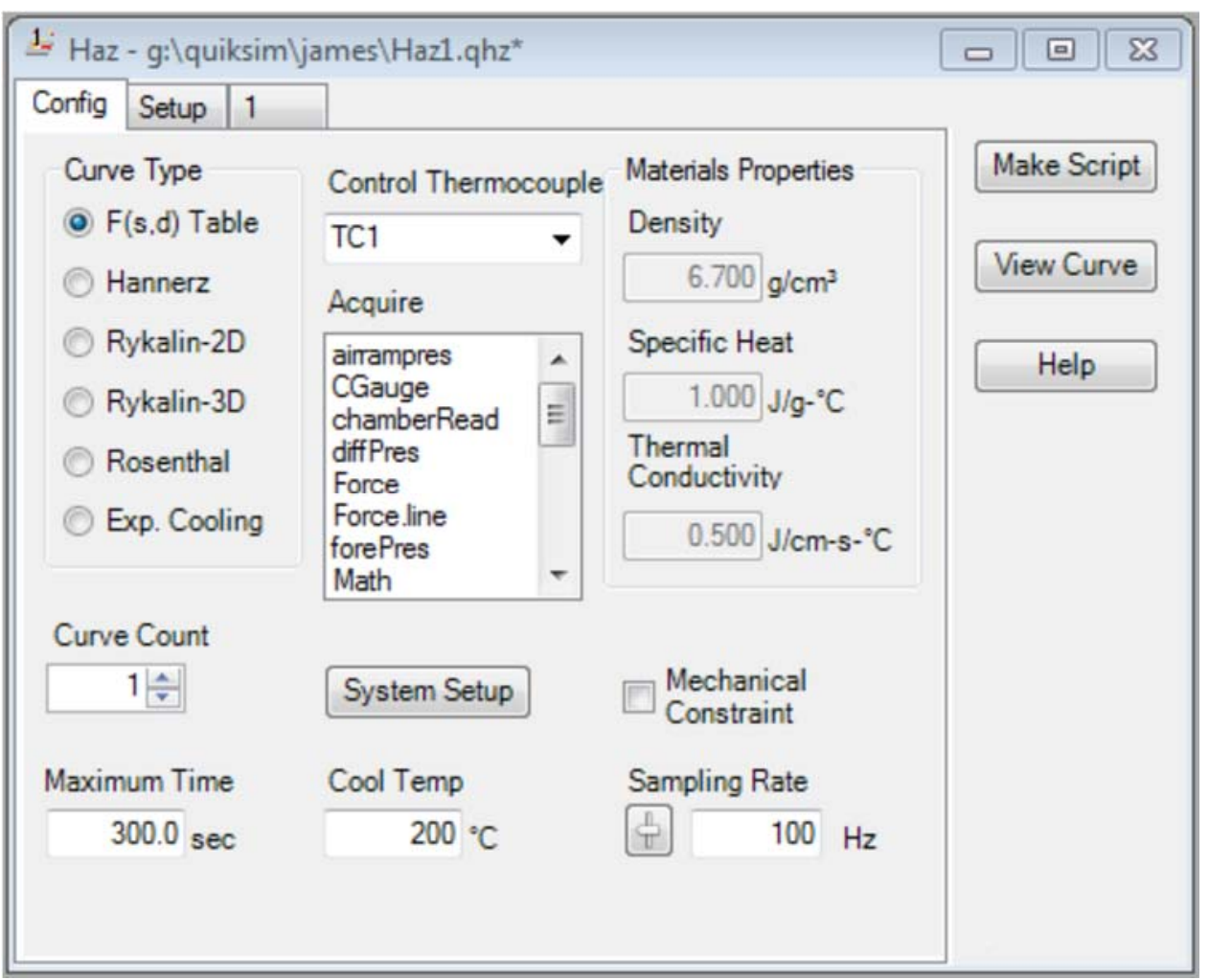

Figura 4-1. Seleção do tipo de curva e propriedades dos AIDs no HAZ Software ${ }^{74}$.

A curva Rykalin-2D foi escolhida para simular os ciclos térmicos de resfriamento tanto na chapa como nos tubos, pois foi considerada para a simulação das ZTAs uma chapa de $10 \mathrm{~mm}(1 \mathrm{~cm})$ de espessura, sendo por tanto uma condição de chapa fina, com distribuição de calor em duas dimensões. O

A equação usada pelo HAZ Software para o cálculo das temperaturas é ${ }^{73}$ 74: 


$$
\begin{aligned}
& T-T_{0}=\frac{a}{\sqrt{b\left(t-t_{0}\right)}} \exp \left(\frac{c}{t-t_{0}}\right) \\
& a=\frac{Q}{d} \quad b=4 \pi k c \rho \quad c=-\frac{r^{2}}{\frac{4 k}{c \rho}} \quad r^{2}=x^{2}+y^{2}
\end{aligned}
$$

Onde:

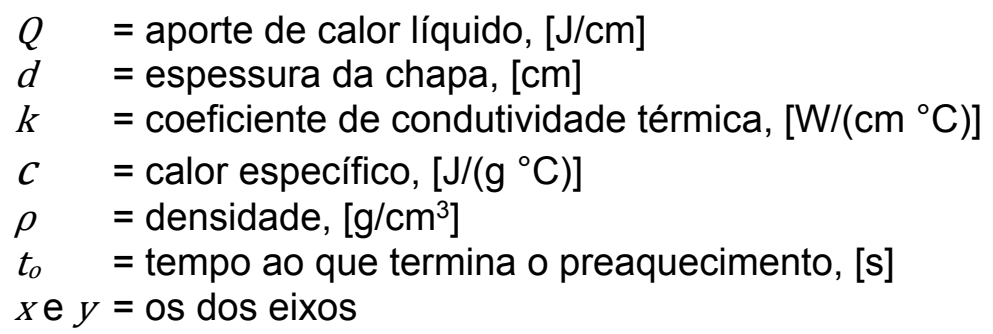

Além disso, o sistema Gleeble deve estar devidamente equipado com as garras de cobre do mesmo formato dos corpos de prova para aceitar o corpo de prova desejado e o tipo de termopar adequado para os testes de simulação de ZTA. O termopar selecionado foi do tipo $k$, esse termopar é de níquel-cromo e alumínio-cromo (cromel / alumel) e trabalha na faixa de temperatura de -200 a $1372^{\circ} \mathrm{C}$, com sensibilidade de $41 \mu \mathrm{V} /{ }^{\circ} \mathrm{C}$. Na opção termopar de controle (Control Termocouple) foram selecionadas as entradas TC1 e TC2 usadas para os dois termopares, a primeira corresponde à temperatura programada e a segunda à leitura da temperatura durante a simulação ${ }^{73} 74$.

Foi planejado via programação capturar (Acquire) duas variáveis durante a simulação, o tempo e a temperatura real. De modo a permitir a comparação entre os ciclos programados com os ciclos executados.

As propriedades do material (Materials Properties) solicitadas pelo HAZ Software, são as mesmas para os três AIDs 757677 :

Densidade $(\rho)=7,8 \mathrm{~g} / \mathrm{cm}^{3}$

Calor específico $(c)=0,68 \mathrm{~J} /\left(\mathrm{g}^{\circ} \mathrm{C}\right)$

Condutibilidade térmica $(\lambda)=0,22 \mathrm{~J} /\left(\mathrm{s} \mathrm{cm}^{\circ} \mathrm{C}\right)$ ou $\mathrm{W} /\left(\mathrm{m}^{\circ} \mathrm{C}\right)$

A caixinha da restrição mecânica (Mechanical Constrain) não foi selecionada, porque os testes de tração não foram realizados na Gleeble. Assim o sistema hidráulico permaneceu inativo durante a simulação da ZTA e deste modo a expansão térmica do corpo de prova é livre para afastar as garras de cobre.

A opção de tempo máximo (Maximum Time) é o maior intervalo de tempo permitido para cada curva. Se esse tempo máximo especificado for atingido, a curva é encerrada, e se houver programada uma nova curva como acontece na soldagem multipasse, esta nova curva começará. Nessa tese, as ZTAs simuladas 
correspondem a soldagens de um passe único. O tempo máximo fixado para todas as simulações foi de 1200 s, que correspondeu ao tempo total de simulação da ZTA para os corpos de prova de aporte de calor de $3,0 \mathrm{~kJ} / \mathrm{mm}$ e têmpera a $250^{\circ} \mathrm{C}$, que são as simulações que tomam maior tempo de todas as programadas.

A temperatura final de cada curva é a temperatura de resfriamento (Cool Temp) e foi fixada em $200^{\circ} \mathrm{C}$. Caso esta temperatura seja atingida o programa dará início a uma nova curva.

Conforme mostrado na seguinte janela de entrada de dados do $H A Z$ Software (Figura 4-2), foi introduzida a temperatura de pico (Maximum Temperature), a qual foi definida durante a simulação pelo software Thermo-Calc 7374 .

A temperatura de preaquecimento (Preheat Temperature) fixada a $25^{\circ} \mathrm{C}$, e o aporte de calor (Energy Input) que é uma das variáveis do projeto (variou de 1,0 até $3,0 \mathrm{~kJ} / \mathrm{mm}$ ), não foi utilizada a opção de cálculo (Calculate).

A taxa de aquecimento (Heating Rate) foi de $350^{\circ} \mathrm{C} / \mathrm{s}$ e o tempo mantido na temperara de pico (Hold Time at Peak) foi de $2 \mathrm{~s}$ sendo o tempo de resfriamento (Cooling Time) calculado pelo software. As constantes (Constants) T1 e T2 correspondem às temperaturas usadas para definir o tempo de resfriamento $\Delta t_{8 / 5}$ onde $\mathrm{T} 1=800^{\circ} \mathrm{C}$ e $\mathrm{T} 2=500^{\circ} \mathrm{C}$.

A espessura da chapa (Plate Thickness) utilizada para a programação de todas as ZTAs nos três aços foi de $10 \mathrm{~mm}(1 \mathrm{~cm})$.

Deste modo é realizada a programação utilizando a extensão ".gsl” (Gleeble Script Language). O código da programação é gerado ao clicar em fazer o script (Make Script). Em seguida as curvas serão geradas ao clicar em ver as curvas (View Curve) as quais devem ser verificadas antes de dar início à simulação ${ }^{73} 74$. 


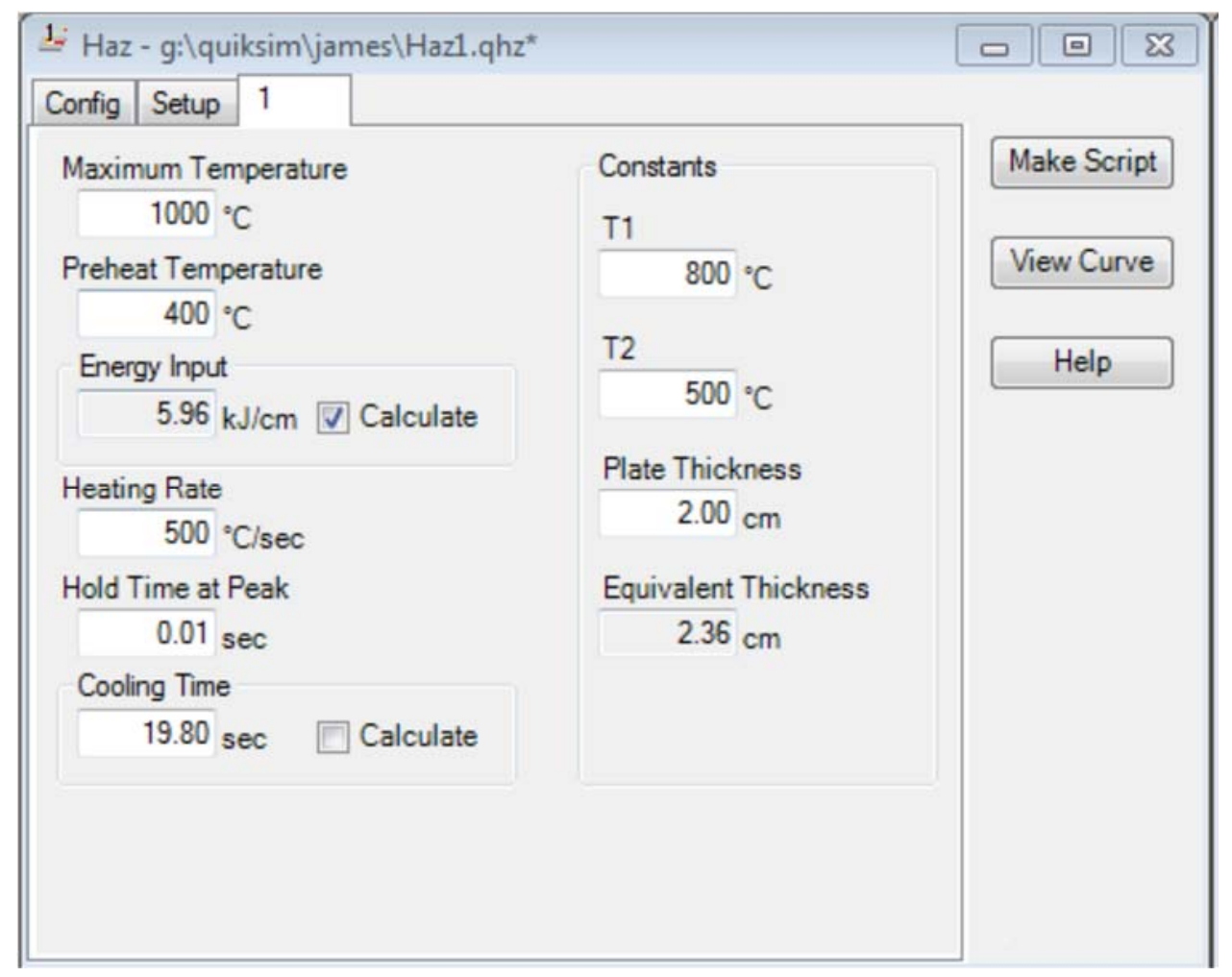

Figura 4-2. Entrada de dados para gerar as curvas da simulação das ZTAs com o modelo de Rykalin-2D ${ }^{74}$.

Para os corpos de prova que precisam de ser temperados com água a $500^{\circ} \mathrm{C}$, foi realizada uma programação adicional neste código, para ocorrer a ativação da têmpera com água quando alcançar essa temperatura. A unidade de têmpera manteve a pressão da água a 70 psi (Figura 4-3).
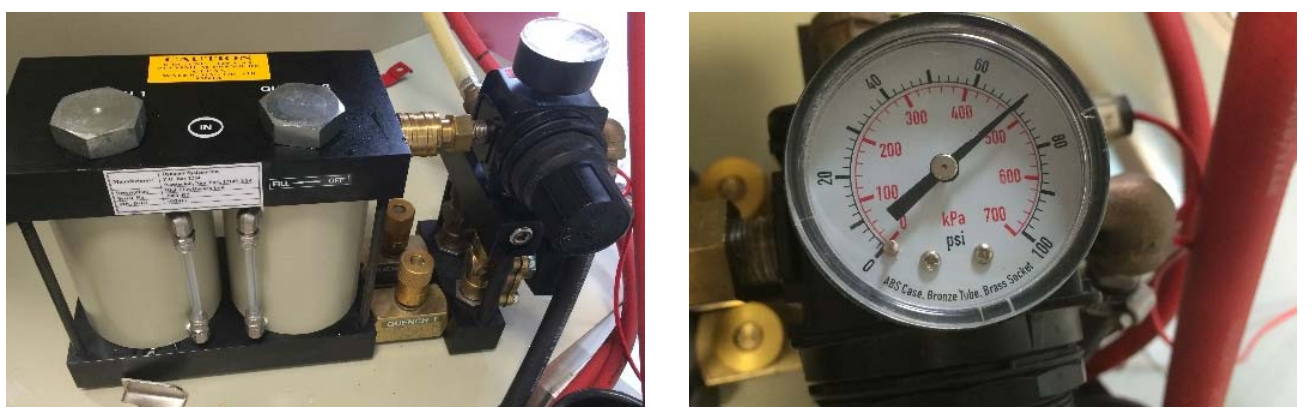

Figura 4-3. Unidade da têmpera na Gleeble.

A Figura 4-4, mostra as geometrias de corpos de prova utilizadas para as simulações das ZTAs as quais foram programadas para obter cinco aportes de calor diferentes, $1,0,1,5,2,0,2,5$ e $3,0 \mathrm{~kJ} / \mathrm{mm}$. 
Os corpos de prova dos AIDs foram usinados conforme às dimensões mostradas na Figura 4-4 (a) para corpos de prova com free span de $10 \mathrm{~mm}$ e na Figura 4-4 (b) para os corpos de prova com $20 \mathrm{~mm}$ de free span.

Os corpos de prova de $10 \mathrm{~mm}$ de free span (Figura 4-4 (a)) foram usados unicamente nas simulações de $1,0 \mathrm{~kJ} / \mathrm{mm}$. Isso ocorreu porque, para poder executar alta velocidade de resfriamento em função de um baixo aporte de calor há a necessidade de utilizar corpos de prova com menor massa (mais curtos). Entre as curvas geradas para os 5 aportes de calor utilizados, as curvas com aporte de calor de $1,0 \mathrm{~kJ} / \mathrm{mm}$ são as que possuem o ciclo de resfriamento mais rápido.

(a)

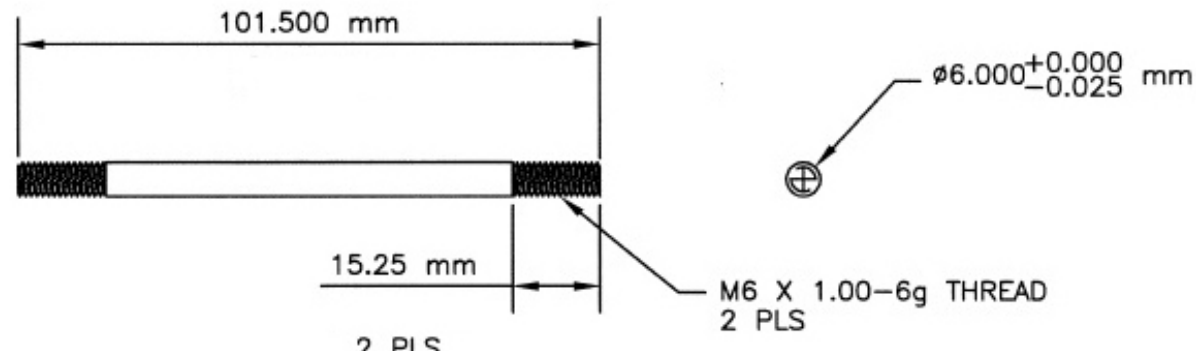

(b)

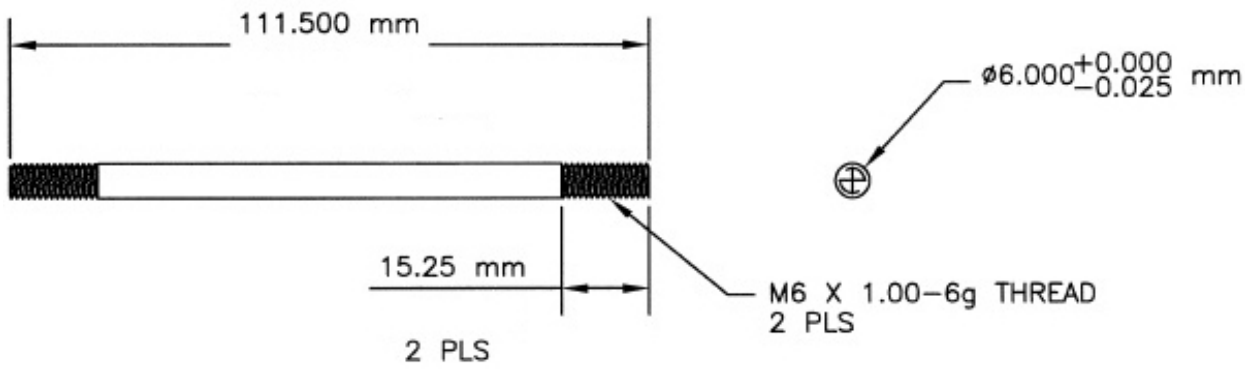

Figura 4-4. Geometrias dos corpos de prova com free span de (a) $10 \mathrm{~mm}$ e (b) $20 \mathrm{~mm}$.

Dois termopares foram soldados na metade da distância do comprimento de cada um dos corpos de prova. Os termopares permitiram controlar as temperaturas programadas assim como obter as leituras da temperatura real.

O corpo de prova com os termopares soldados foi acoplado às garras de cobre (o cobre mantém o gradiente térmico significativo durante a simulação ao longo do eixo do corpo de prova) e as porcas de aço inoxidável (mantem o corpo de prova fixo durante a simulação) (Figura 4-5). 


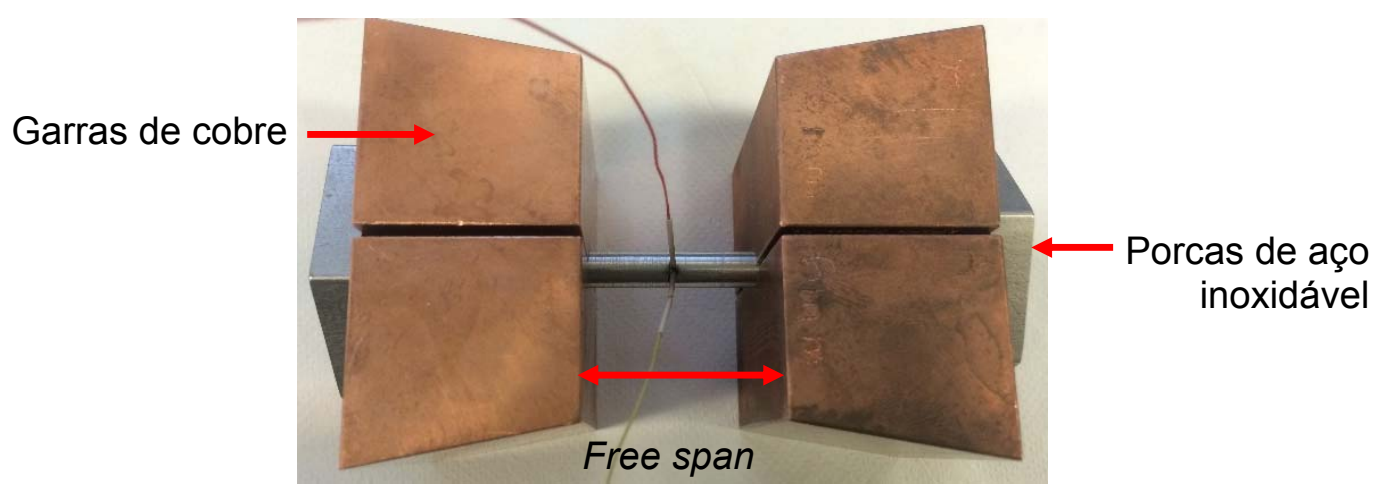

Figura 4-5. Corpo de prova com os dois termopares soldados acoplado às garras de cobre e porcas de aço inoxidável.

Os ciclos térmicos foram programados utilizando uma taxa de aquecimento de $350^{\circ} \mathrm{C} / \mathrm{s}$ desde a temperatura ambiente até a temperatura de pico com tempo de permanência de 2 segundos nesta temperatura. A temperatura de pico corresponde à temperatura de ferritização completa do aço segundo os resultados obtidos pelo software Thermo-Calc.

As taxas de resfriamento segundo o modelo Rykalin-2D foram programadas para dois grupos de corpos de prova. O primeiro grupo foi resfriado até $500^{\circ} \mathrm{C}$, nesta temperatura considera-se que o processo de formação de austenita foi concluído; seguido de uma têmpera em água até a temperatura ambiente. Para a têmpera em água foi instalado um aspersor de água no interior da câmara da Gleeble que limitou o free span entre as garras (Figura 4-6), permitindo simular as ZTAs com 4 aportes de calor 1,5, 2,0, 2,5 e 3,0 kJ/mm (Figura 4-7 (a)).

O segundo grupo de corpos de prova foi resfriado segundo o modelo Rykalin-2D até $250^{\circ} \mathrm{C}$ (nessa temperatura considera-se que os processos de transformações de fases foram finalizados), e seguido de uma têmpera até a temperatura ambiente. Para esse segundo grupo foram simuladas as ZTAs com 5 aportes de calor 1,0, 1,5, 2,0, 2,5 e 3,0 kJ/mm (Figura 4-7 (b)).

As simulações com aporte de calor de $1,0 \mathrm{~kJ} / \mathrm{mm}$ requereu o uso do corpo de prova de geometria Gleeble de $10 \mathrm{~mm}$ de free span (Figura 4-4 (a)). Todas as simulações da ZTAs foram executadas mantendo a câmara da Gleeble com pressão de $5 \times 10^{-3}$ torr. 


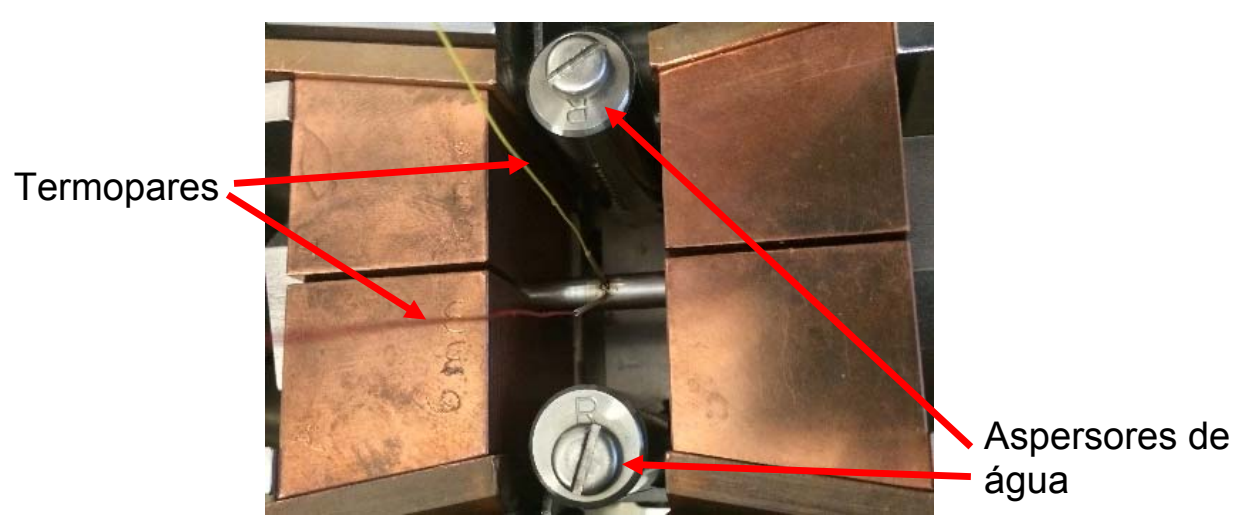

Figura 4-6. Corpo de prova de $20 \mathrm{~mm}$ de free span com os dois termopares soldados e acoplado na câmara da Gleeble.
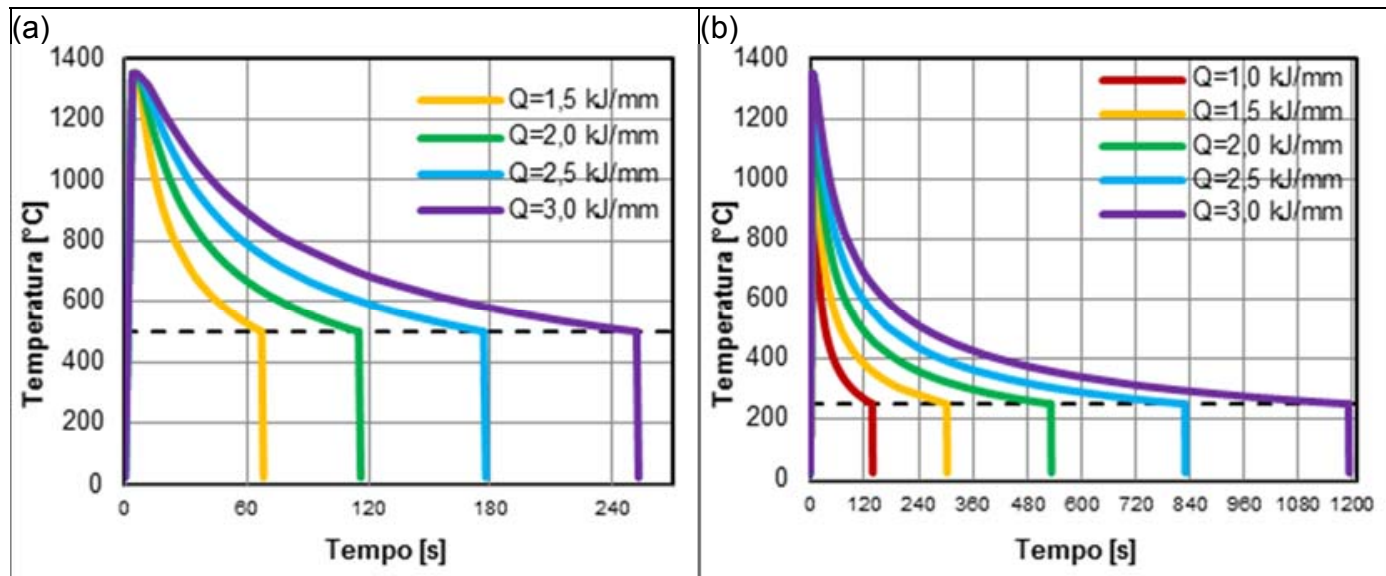

Figura 4-7. Ciclos térmicos programados no HAZ Software em ambiente Gleeble. (a) Primeiro grupo de corpos e prova com têmpera em água a $500^{\circ} \mathrm{C}$. (b) Segundo grupo de corpos de prova com têmpera a $250^{\circ} \mathrm{C}$.

Os aportes de calor e os tempos de resfriamento calculados $\Delta t_{12 / 8}$ (entre $1200^{\circ} \mathrm{C}$ e $800^{\circ} \mathrm{C}$ ) e $\Delta t_{8} / 5$ (entre 800 e $500^{\circ} \mathrm{C}$ ) correspondentes aos ciclos térmicos programados durante a simulação física na Gleeble estão apresentados na Tabela 4-4.

Tabela 4-4. Tempos de resfriamento para os aportes de calor estudados.

\begin{tabular}{|l|c|c|c|c|c|}
\hline & \multicolumn{5}{|c|}{ Aportes de Calor [kJ/mm] } \\
\cline { 2 - 6 } & 1,0 & 1,5 & 2,0 & 2,5 & 3,0 \\
\hline$\Delta t_{12 / 8}[\mathbf{s}]$ & 6,7 & 15,0 & 26,8 & 41,8 & 60,2 \\
\hline$\Delta t_{8 / 5}[\mathbf{s}]$ & 18,9 & 42,6 & 75,8 & 118,4 & 170,5 \\
\hline
\end{tabular}

$\mathrm{Na}$ Tabela 4-5 são apresentadas as nove curvas programadas para a simulação das ZTAs segundo o modelo Rykalin 2D, quatro curvas para o primeiro 
grupo de corpos de prova com aportes de calor de 1,5, 2,0, 2,5 e 3,0 kJ/mm e têmpera com água a $500^{\circ} \mathrm{C}$; e cinco curvas para o segundo grupo de corpos de prova com aportes de calor de 1,0, 1,5, 2,0, 2,5 e 3,0 kJ/mm e têmpera a $250^{\circ} \mathrm{C}$.

Tabela 4-5. As 9 curvas programadas para a simulação das ZTAs na Gleeble.

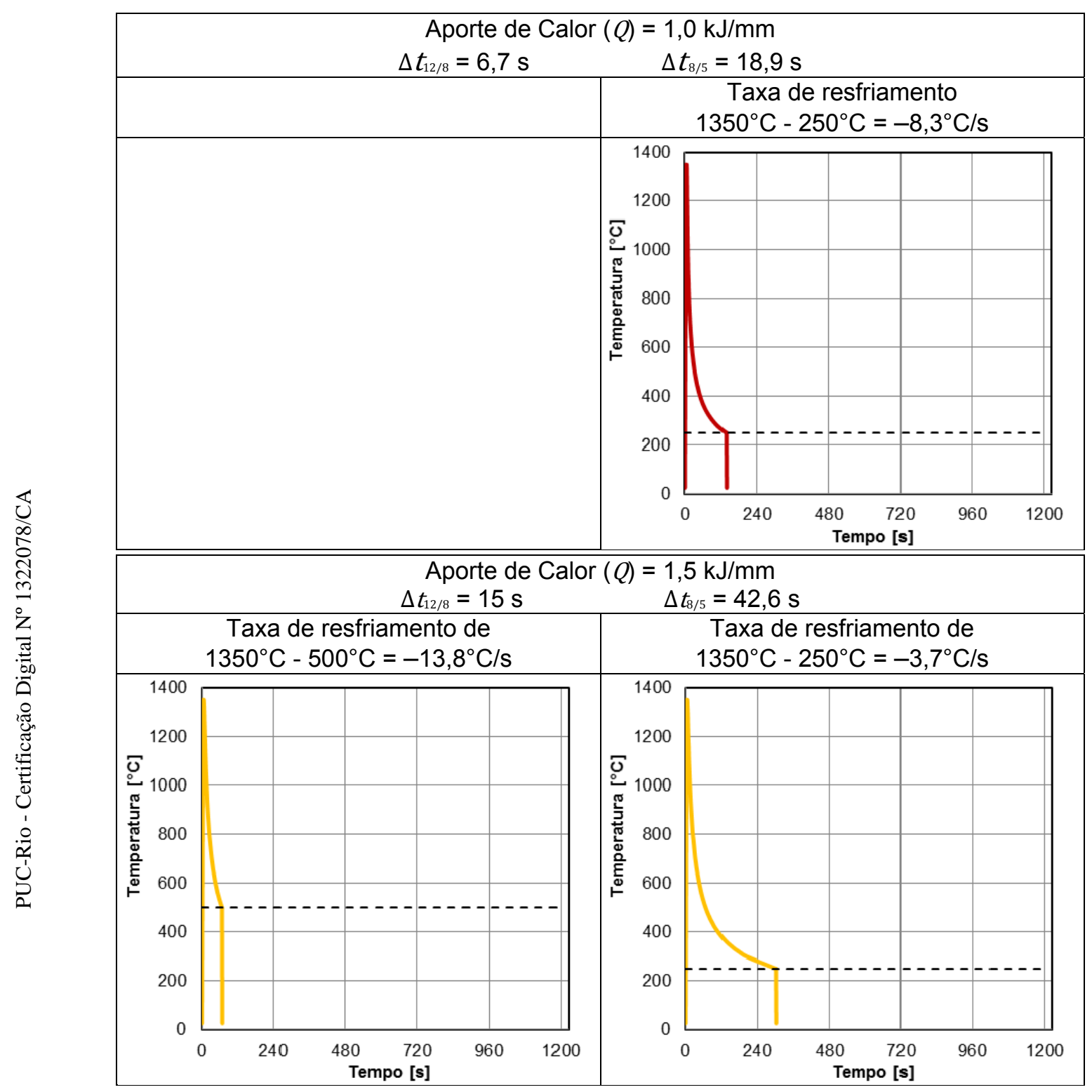



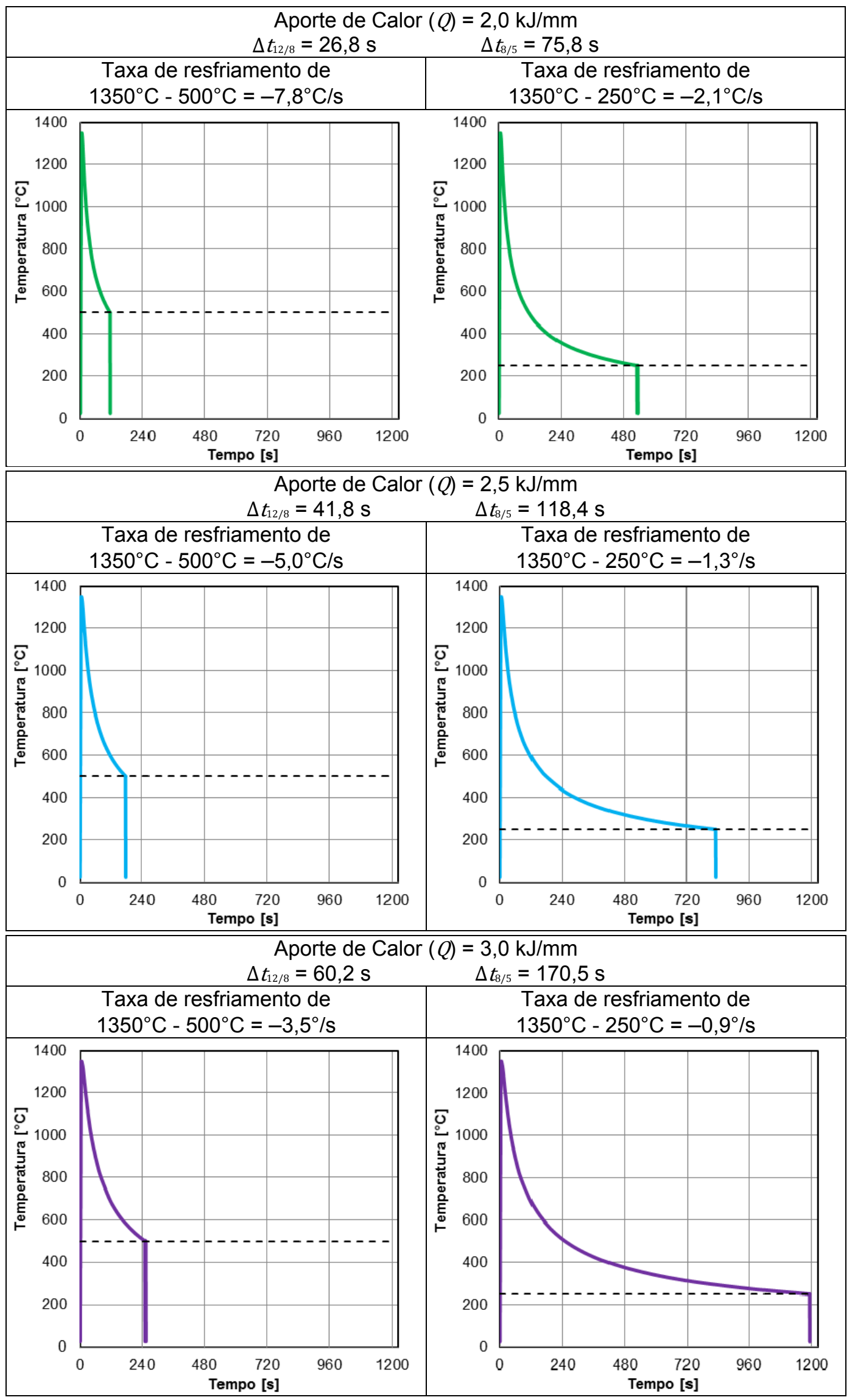
Cada uma das 4 curvas programadas do primeiro grupo de corpos de prova com aportes de calor de 1,5, 2,0, 2,5 e $3,0 \mathrm{~kJ} / \mathrm{mm}$ e têmpera com água a $500^{\circ} \mathrm{C}$, foram 6 vezes executadas para cada aço, obtendo 24 corpos de prova com a ZTA simulada para cada aço, os que correspondem a 72 corpos de provas com ZTA simulada, deste primeiro grupo. Esses corpos de prova foram destinados para a caracterização por tração, microestrutural e microdureza das ZTAs como se indica na Tabela 4-6.

Tabela 4-6. Primeiro grupo de corpos de prova com 4 aportes de calor e têmpera com água a $500^{\circ} \mathrm{C}$.

\begin{tabular}{|c|c|c|c|}
\hline AID & $\begin{array}{l}\text { Aporte de } \\
\text { Calor } \\
{[\mathrm{kJ} / \mathrm{mm}]}\end{array}$ & $\begin{array}{l}\text { Quantidade de } \\
\text { Corpos de Prova }\end{array}$ & Caraterização \\
\hline \multirow{4}{*}{$\begin{array}{c}\text { S32304 } \\
(2304)\end{array}$} & 1,5 & 6 & $\begin{array}{l}3 \text { Tração mecânica } \\
2 \text { Microscopia Ótica, Microdureza } \\
1 \text { Contra amostra }\end{array}$ \\
\hline & 2,0 & 6 & $\begin{array}{l}3 \text { Tração mecânica } \\
2 \text { Microscopia Ótica, Microdureza } \\
1 \text { Contra amostra }\end{array}$ \\
\hline & 2,5 & 6 & $\begin{array}{l}3 \text { Tração mecânica } \\
2 \text { Microscopia Ótica, Microdureza } \\
1 \text { Contra amostra }\end{array}$ \\
\hline & 3,0 & 6 & $\begin{array}{l}3 \text { Tração mecânica } \\
2 \text { Microscopia Ótica, Microdureza } \\
1 \text { Contra amostra }\end{array}$ \\
\hline \multirow{4}{*}{$\begin{array}{c}\text { S32205 } \\
\text { (SAF 2205) }\end{array}$} & 1,5 & 6 & $\begin{array}{l}3 \text { Tração mecânica } \\
2 \text { Microscopia Ótica, Microdureza } \\
1 \text { Contra amostra }\end{array}$ \\
\hline & 2,0 & 6 & $\begin{array}{l}3 \text { Tração mecânica } \\
2 \text { Microscopia Ótica, Microdureza } \\
1 \text { Contra amostra }\end{array}$ \\
\hline & 2,5 & 6 & $\begin{array}{l}3 \text { Tração mecânica } \\
2 \text { Microscopia Ótica, Microdureza } \\
1 \text { Contra amostra }\end{array}$ \\
\hline & 3,0 & 6 & $\begin{array}{l}3 \text { Tração mecânica } \\
2 \text { Microscopia Ótica, Microdureza } \\
1 \text { Contra amostra }\end{array}$ \\
\hline \multirow{4}{*}{$\begin{array}{c}\text { S32750 } \\
\text { (SAF 2507) }\end{array}$} & 1,5 & 6 & $\begin{array}{l}3 \text { Tração mecânica } \\
2 \text { Microscopia Ótica, Microdureza } \\
1 \text { Contra amostra }\end{array}$ \\
\hline & 2,0 & 6 & $\begin{array}{l}3 \text { Tração mecânica } \\
2 \text { Microscopia Ótica, Microdureza } \\
1 \text { Contra amostra }\end{array}$ \\
\hline & 2,5 & 6 & $\begin{array}{l}3 \text { Tração mecânica } \\
2 \text { Microscopia Ótica, Microdureza } \\
1 \text { Contra amostra }\end{array}$ \\
\hline & 3,0 & 6 & $\begin{array}{l}3 \text { Tração mecânica } \\
2 \text { Microscopia Ótica, Microdureza } \\
1 \text { Contra amostra }\end{array}$ \\
\hline
\end{tabular}

Em quanto as curvas do segundo grupo de corpos de prova com aportes de calor de $1,0,1,5,2,0,2,5$ e $3,0 \mathrm{~kJ} / \mathrm{mm}$ e têmpera a $250^{\circ} \mathrm{C}$, foram executadas 2 
vezes cada uma delas para cada aço, obtendo 10 corpos de prova com as ZTA simuladas para aço, que correspondem a 30 corpos de prova com a ZTA simulada neste segundo grupo. Esse segundo grupo de corpos de prova foi utilizado na caracterização microestrutural e na microdureza das ZTAs como se indica na Tabela 4-7.

No total foram obtidos 102 corpos de prova com a ZTA simulada, o que corresponde a 34 corpos de prova com a ZTA simulada em cada um dos 3 aços estudados.

As simulações das ZTAs no aço inoxidável duplex UNS S32205 foram realizadas no Centro de Tecnologia de Solda "Orlando Barbosa" do Serviço Nacional de Aprendizagem Industrial (SENAI) do Rio de Janeiro, e as simulações das ZTAs no aço inoxidável lean duplex UNS S32304 e no aço inoxidável super duplex UNS S32750 foram executadas no laboratório Labnano do Centro Nacional de pesquisa em Energia e Materiais (CNPEM) na Campinas-SP.

Tabela 4-7. Segundo grupo de corpos de prova com 4 aportes de calor e têmpera a $250^{\circ} \mathrm{C}$.

\begin{tabular}{|c|c|c|c|}
\hline AID & $\begin{array}{l}\text { Aporte de } \\
\text { Calor } \\
\text { [kJ/mm] }\end{array}$ & $\begin{array}{c}\text { Quantidade } \\
\text { de Corpos de } \\
\text { Prova }\end{array}$ & Caraterização \\
\hline \multirow{5}{*}{$\begin{array}{c}\text { S32304 } \\
(2304)\end{array}$} & 1,0 & 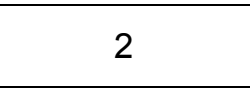 & $\begin{array}{l}1 \text { Microscopia Ótica MEV, Microdureza } \\
1 \text { Contra amostra }\end{array}$ \\
\hline & 1,5 & 2 & $\begin{array}{l}1 \text { Microscopia Ótica MEV, Microdureza } \\
1 \text { Contra amostra }\end{array}$ \\
\hline & 2,0 & 2 & $\begin{array}{l}1 \text { Microscopia Ótica MEV, Microdureza } \\
1 \text { Contra amostra }\end{array}$ \\
\hline & 2,5 & 2 & $\begin{array}{l}1 \text { Microscopia Ótica MEV, Microdureza } \\
1 \text { Contra amostra }\end{array}$ \\
\hline & 3,0 & 2 & $\begin{array}{l}1 \text { Microscopia Ótica MEV, Microdureza } \\
1 \text { Contra amostra }\end{array}$ \\
\hline \multirow{5}{*}{$\begin{array}{l}\text { S32205 } \\
\text { (SAF 2205) }\end{array}$} & 1,0 & 2 & $\begin{array}{l}1 \text { Microscopia Ótica MEV, Microdureza } \\
1 \text { Contra amostra }\end{array}$ \\
\hline & 1,5 & 2 & $\begin{array}{l}1 \text { Microscopia Ótica MEV, Microdureza } \\
1 \text { Contra amostra }\end{array}$ \\
\hline & 2,0 & 2 & $\begin{array}{l}1 \text { Microscopia Ótica MEV, Microdureza } \\
1 \text { Contra amostra }\end{array}$ \\
\hline & 2,5 & 2 & $\begin{array}{l}1 \text { Microscopia Ótica MEV, Microdureza } \\
1 \text { Contra amostra }\end{array}$ \\
\hline & 3,0 & 2 & $\begin{array}{l}1 \text { Microscopia Ótica MEV, Microdureza } \\
1 \text { Contra amostra }\end{array}$ \\
\hline \multirow{5}{*}{$\begin{array}{l}\text { S32750 } \\
(\text { SAF 2507) }\end{array}$} & 1,0 & 2 & $\begin{array}{l}1 \text { Microscopia Ótica MEV, Microdureza } \\
1 \text { Contra amostra }\end{array}$ \\
\hline & 1,5 & 2 & $\begin{array}{l}1 \text { Microscopia Ótica MEV, Microdureza } \\
1 \text { Contra amostra }\end{array}$ \\
\hline & 2,0 & 2 & $\begin{array}{l}1 \text { Microscopia Ótica MEV, Microdureza } \\
1 \text { Contra amostra }\end{array}$ \\
\hline & 2,5 & 2 & $\begin{array}{l}1 \text { Microscopia Ótica MEV, Microdureza } \\
1 \text { Contra amostra }\end{array}$ \\
\hline & 3,0 & 2 & $\begin{array}{l}1 \text { Microscopia Ótica MEV, Microdureza } \\
1 \text { Contra amostra }\end{array}$ \\
\hline
\end{tabular}




\subsection{4. \\ Caraterização Metalográfica}

As amostras metalográficas da seções longitudinais ao sentido de laminação da chapa (UNS S32304) e dos tubos (UNS S32205 e S32750) na condição de como-recebido foram cortadas com um área aproximada de $1 \mathrm{~cm}^{2}$. No caso dos corpos de prova das ZTAs simuladas, foram cortados transversalmente ao sentido de laminação, exatamente na posição dos termopares com cortadora de precisão, obtendo amostras circulares com $6 \mathrm{~mm}$ de diâmetro e aproximadamente $10 \mathrm{~mm}$ de espessura. Em seguida, as 30 amostras ( 3 amostras dos aços na condição de como-recebido e 27 amostras das ZTAs simuladas) foram embutidas em resina epóxi para a preparação metalográfica convencional. As superfícies das amostras foram submetidas a lixamento úmido usando lixas de granulometria de 360, 600 e 1200, seguidas de polimento manual com pasta de diamante de 6 e $1 \mu \mathrm{m}$ e lubrificante etanol $98 \%$.

Foram utilizados dois tipos de ataque para revelar as duas fases presentes (austenita e ferrita). O primeiro foi o ataque químico com solução Beraha modificada 7850 79; 8081188231 (10 ml de HCl, 0,35 gr de $\mathrm{K}_{2} \mathrm{~S}_{2} \mathrm{O}_{5}$ em $70 \mathrm{ml}$ de água destilada) durante $8 \mathrm{~s}$ a temperatura ambiente. A solução Beraha ataca seletivamente a fase ferrítica oferecendo bom contraste entre as fases primarias do AIDs, austenita e ferrita.

O segundo foi o ataque eletrolítico com solução de KOH 338359845548852286 878889 66; 90 a $50 \%$ com $3 \mathrm{~V}$ durante $10 \mathrm{~s}$. Esse eletrólito ataca levemente a austenita, a ferrita é atacada e colorida em tons azul/roxo e ataca fortemente à fase $\sigma$ ficando colorida em tons marrom/laranja/preto.

Isto permitiu comparar o efeito dos ataques ao revelar as fases da austenita e ferrita na mesma amostra e consequentemente permitiu selecionar o ataque que oferece melhor contraste e assim facilitar o processamento digital de imagens para a contagem de fases.

As micrografias dos AIDs na condição de como-recebido e das ZTAs simuladas foram obtidas por microscopia ótica em campo claro (microscópio ZEISS modelo Axioplan 2 Imaging, câmara AxioCam HRc e com o software AxioVision 4.8.2 do Laboratório de Processamento Digital de Imagens - LPDI) em diferentes aumentos. Para realizar a contagem de fases e para a medição do tamanho de grão, foram capturadas aproximadamente 20 imagens de cada amostra, em branco e preto, com aumento de $200 \mathrm{X}$. 
Para o processamento digital e a contagem de fases nas imagens foi utilizado o software Fiji. O processamento das imagens constitui na correção de iluminação, brilho / contraste e foram aplicados filtros para redução de ruído e identificação dos contornos de grão. Após estes procedimentos foram calculadas as frações de área clara e escura as quais correspondem respectivamente às frações volumétricas de austenita e ferrita. A estatística aplicada a esses resultados foi a distribuição $t$ de Student com intervalo de confiança $0,975 \%$ bicaudal.

Um novo procedimento metalográfico foi realizado para identificar a presença de precipitados. As amostras foram embutidas em resina fenólica condutora na prensa Leco PR-36 com pressão de 4400 psi a $150^{\circ} \mathrm{C}$, e submetidas a lixamento úmido usando lixas de granulometria de 800 e 1200 e polidas manualmente em pasta de diamante de $1 \mu \mathrm{m}$ com o lubrificante próprio da pasta (compound extender) e suspensão de sílica de 0,05 $\mu \mathrm{m}$ utilizando água como lubrificante.

Foi realizado um ataque eletrolítico com solução de 40\% de $\mathrm{HNO}_{3} 65919293$ ${ }^{29} \mathrm{em}$ água destilada em duas etapas. A primeira etapa com 1,2 V durante $2 \mathrm{~min}$ que revela as interfaces e contornos de grãos, e a segunda etapa com $0,7 \mathrm{~V}$ durante 7 min para aumentar o contraste entre a ferrita, a austenita primária e a austenita secundária. As imagens foram capturadas no microscópio ótico metalúrgico invertido Olympus, modelo GX51 com o software DP2-BSW em campo claro e por DIC.

A técnica de DIC utiliza dois feixes de luz polarizada e as imagens combinadas aparecem como se as fases estivessem projetando sombras para um lado. Em metalografia essa técnica é usada para observar a topografia da superfície das amostras e para obter contraste das fases.

Nas micrografias das simulações das ZTAs dos três aços estudados capturadas com aumento de 200X que foram usadas para as contagens de fases, foi medido o tamanho de grão da ferrita mediante o diâmetro dos grãos [ $\mu \mathrm{m}]$. A medição dos diâmetros dos grãos de ferrita que se apresentaram inteiros nessas micrografias foi feita digitalmente com o software Fiji. 


\subsection{5.}

\section{Testes de Tração}

Em acordo com as especificações da norma ASTM A240-15 ${ }^{69}$ a Tabela 4-8 apresenta as propriedades mecânicas mínimas dos AIDs em estudo.

Tabela 4-8. Especificações da propriedades mecânicas dos AIDs em estudo segundo a ASTM A240-15 69 .

\begin{tabular}{|c|c|c|c|}
\hline AIDs & $\begin{array}{c}\text { Limite de Escoamento, min } \\
{[\mathrm{MPa}]}\end{array}$ & $\begin{array}{c}\text { Limite de Resistência, min } \\
{[\mathrm{MPa}]}\end{array}$ & $\begin{array}{c}\text { Alongamento em 50 mm, min } \\
{[\%]}\end{array}$ \\
\hline $\begin{array}{c}\text { UNS S32304 } \\
\text { (2304) }\end{array}$ & 400 & 600 & 25 \\
\hline $\begin{array}{c}\text { UNS S32205 } \\
\text { (SAF 2205) }\end{array}$ & 450 & 655 & 25 \\
\hline $\begin{array}{c}\text { UNS S32750 } \\
\text { (SAF 2507) }\end{array}$ & 550 & 795 & 15 \\
\hline
\end{tabular}

O ensaio de tração foi realizado com o objetivo de se determinar as seguintes propriedades mecânicas: i) limite de escoamento; ii) limite de resistência e iii) alongamento percentual seguindo as especificações da norma ASTM A370$17^{94}$.

Foram usinados dois tipos de corpos de prova para testar por tração os AIDs na condição de como-recebido. O primeiro tipo de corpo de prova é de geometria reduzida seguindo as especificações da norma ASTM E8/E8M-1695 (Figura 4-8). A dimensão $B$ foi acrescida de 30 para $55 \mathrm{~mm}$, de modo a permitir a fixação na garra da máquina universal.
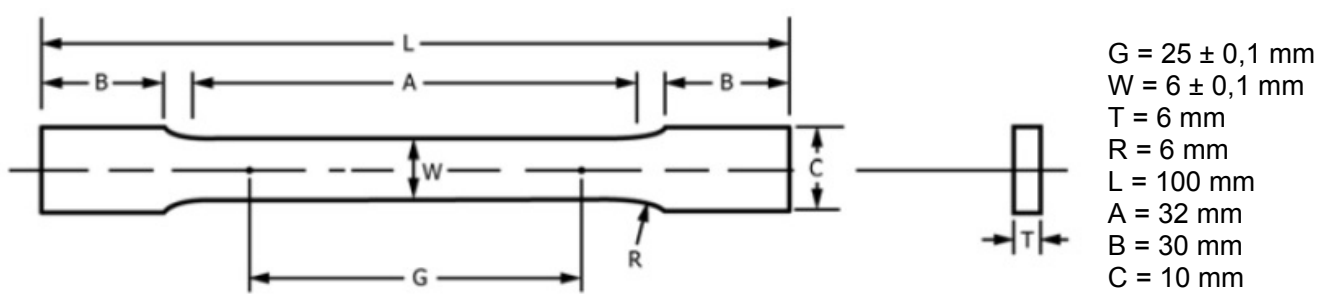

Figura 4-8. Corpo de prova de geometria reduzida segundo a norma ASTM E8/E8M-16 ${ }^{95}$.

O segundo tipo de corpo de prova testado, seguiu a geometria dos corpos de prova utilizados na simulação física (Gleeble) com free span de $20 \mathrm{~mm}$. Este modelo de corpo de prova possui um pescoço usinado na altura do centro do comprimento de modo a concentrar as tensões na região da área transversal 
reduzida ( $3 \mathrm{~mm}$ de diâmetro) durante os testes de tração e assegurar que a fratura ocorra nessa região (Figura 4-9).

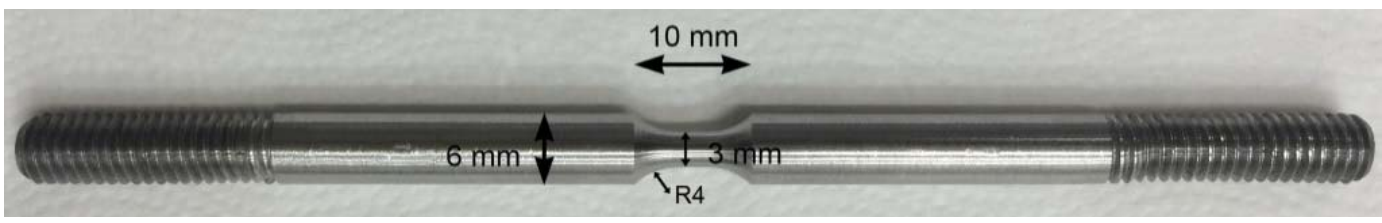

Figura 4-9. Imagem do corpo de prova de $20 \mathrm{~mm}$ de free span com o pescoço usinado de $3 \mathrm{~mm}$ de diâmetro.

Os corpos de prova com as ZTAs simuladas e temperadas a $500^{\circ} \mathrm{C}$ também foram testados mecanicamente por tração. Foi utilizado somente o corpo de prova de geometria de $20 \mathrm{~mm}$ de free span do simulador Gleeble. O pescoço de $3 \mathrm{~mm}$ de diâmetro foi usinado adicionalmente depois de ter feita à simulação da ZTA (Figura 4-9).

Os corpos de prova de geometria Gleeble (aços como-recebido e ZTAs simuladas) quando testados em tração utilizaram um acessório rosqueado para melhorar a fixação na garra da máquina universal (Figura 4-10), isto foi necessário porque o diâmetro dos corpos de prova era pequeno $(6 \mathrm{~mm})$ e assim se evitou o escorregamento dos corpos de prova durante os testes de tração o que limitou a utilização do extensômetro.
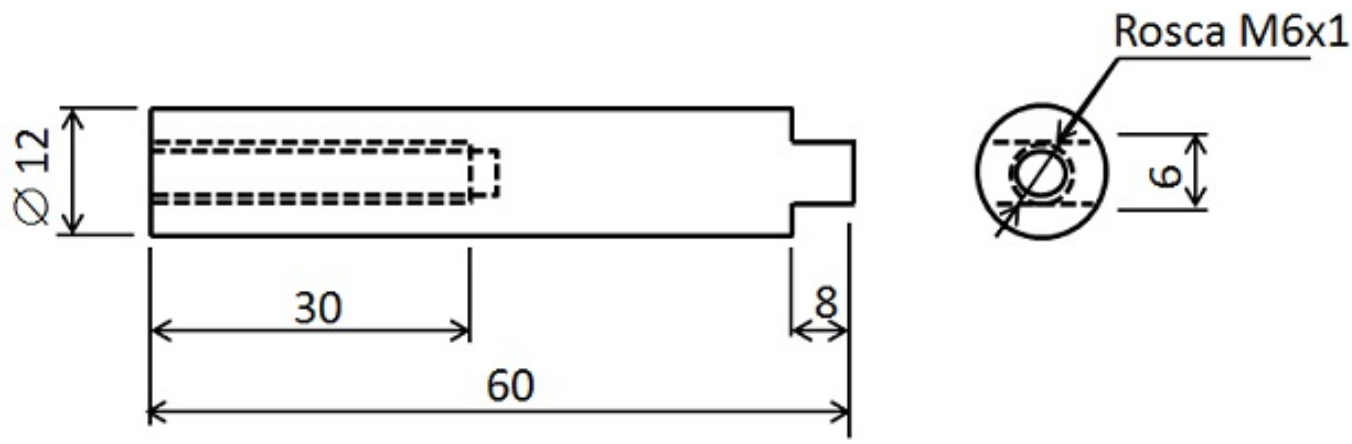

Figura 4-10. Acessório de cabeças roscadas para usar nos corpos de prova da Gleeble, dimensões em mm (desenhado pelo Professor Juan Alberto Pozo).

Todos os testes de tração foram realizados no Centro Federal de Educação Tecnológica Celso Suckow da Fonseca - Cefet / RJ Campus Maracanã, na máquina universal Instron modelo 5985 com capacidade de 250 kN de carga, e com o software Bluehill 3. Ensaiaram-se, para cada condição três corpos de prova seguindo as especificações mínimas da norma ASTM A370-17 ${ }^{94}$. 
Cada teste de tração foi realizado em triplicata, para obter um total de 54 testes de tração como mostrado na Tabela 4-9.

Tabela 4-9. Quantidade de corpos de prova testados por tração.

\begin{tabular}{|l|l|l|}
\hline \multicolumn{1}{|c|}{ Aço } & \multicolumn{1}{|c|}{$\begin{array}{c}\text { Geometria do } \\
\text { Corpo de Prova }\end{array}$} & \multicolumn{1}{c|}{ Condição } \\
\hline S32304 (2304) & Reduzida & Como-recebido \\
\hline S32304 (2304) & Gleeble & Como-recebido \\
\hline S32304 (2304) & Gleeble & ZTA $Q=1,5 \mathrm{~kJ} / \mathrm{mm}$ têmpera a $500^{\circ} \mathrm{C}$ \\
\hline S32304 (2304) & Gleeble & ZTA $Q=2,0 \mathrm{~kJ} / \mathrm{mm}$ têmpera a $500^{\circ} \mathrm{C}$ \\
\hline S32304 (2304) & Gleeble & ZTA $Q=2,5 \mathrm{~kJ} / \mathrm{mm}$ têmpera a $500^{\circ} \mathrm{C}$ \\
\hline S32304 (2304) & Gleeble & ZTA $Q=3,0 \mathrm{~kJ} / \mathrm{mm}$ têmpera a $500^{\circ} \mathrm{C}$ \\
\hline S32205 (SAF 2205) & Reduzida & Como-recebido \\
\hline S32205 (SAF 2205) & Gleeble & Como-recebido \\
\hline S32205 (SAF 2205) & Gleeble & ZTA $Q=1,5 \mathrm{~kJ} / \mathrm{mm}$ têmpera a $500^{\circ} \mathrm{C}$ \\
\hline S32205 (SAF 2205) & Gleeble & ZTA $Q=2,0 \mathrm{~kJ} / \mathrm{mm}$ têmpera a $500^{\circ} \mathrm{C}$ \\
\hline S32205 (SAF 2205) & Gleeble & ZTA $Q=2,5 \mathrm{~kJ} / \mathrm{mm}$ têmpera a $500^{\circ} \mathrm{C}$ \\
\hline S32205 (SAF 2205) & Gleeble & ZTA $Q=3,0 \mathrm{~kJ} / \mathrm{mm}$ têmpera a $500^{\circ} \mathrm{C}$ \\
\hline S32750 (SAF 2507) & Reduzida & Como-recebido \\
\hline S32750 (SAF 2507) & Gleeble & Como-recebido \\
\hline S32750 (SAF 2507) & Gleeble & ZTA $Q=1,5 \mathrm{~kJ} / \mathrm{mm}$ têmpera a $500^{\circ} \mathrm{C}$ \\
\hline S32750 (SAF 2507) & Gleeble & ZTA $Q=2,0 \mathrm{~kJ} / \mathrm{mm}$ têmpera a $500^{\circ} \mathrm{C}$ \\
\hline S32750 (SAF 2507) & Gleeble & ZTA $Q=2,5 \mathrm{~kJ} / \mathrm{mm}$ têmpera a $500^{\circ} \mathrm{C}$ \\
\hline S32750 (SAF 2507) & Gleeble & ZTA $Q=3,0 \mathrm{~kJ} / \mathrm{mm}$ têmpera a $500^{\circ} \mathrm{C}$ \\
\hline
\end{tabular}

Os corpos de prova foram testados até à fratura com carga de tração aplicada uniaxialmente e com taxa constante ao longo do eixo.

Apenas os corpos de prova de geometria reduzida foram medidas as elongações usando um extensômetro. Em função da geometria dos corpos de prova da Gleeble, as elongações não foram medidas.

Os dados coletados durante os testes de tração foram o tempo [s], alongamento [mm] (quando usado o extensômetro) e carga [N]. Esta informação permitiu construir as curvas do comportamento mecânico por tração.

A carga e a elongação foram normalizadas para os respectivos parâmetros de acordo com os parâmetros de tensão $(\sigma)$ e deformação de engenharia $(\varepsilon)$ de modo a minimizar fatores geométricos dos corpos de prova. 
As características carga-deformação são dependentes do tamanho de corpo de prova. Para minimizar esses fatores geométricos, a carga e o alongamento são normalizados para os respectivos parâmetros de tensão de engenharia versus deformação engenharia ( $\sigma$ vs $\varepsilon$ ), os quais foram calculados para cada um dos testes realizados mediante a Equação 4-2 ${ }^{96}$.

$\sigma=\frac{F}{A_{o}} \quad \varepsilon=\frac{\Delta l}{l_{o}}$

Equação 4-2

Onde:

$F=$ Carga instantânea aplicada em direção perpendicular à secção transversal do corpo de prova $[\mathrm{N}]$

$A_{0}=$ Área original da seção transversal antes da aplicação da carga [m²].

$l_{o}=$ Comprimento original antes de aplicar a carga $[\mathrm{mm}]$.

$\Delta l=\left(l_{i}-l_{o}\right)$ Variação no comprimento no corpo de prova em um dado instante. Diferença entre o Comprimento instantâneo e o Comprimento original do corpo de prova.

Após do teste de tração aos corpos de prova foram capturadas algumas imagens no MEV de marca JEOL e modelo JFM-6510 LV com detector de elétrons secundários para verificar o tipo de fratura que apresentaram as ZTAs simuladas.

\subsection{6.}

Microdureza Vickers

Conforme mostrado na Tabela 4-10, de acordo com a norma ASTM A240$15^{69}$, estão listadas as durezas máximas em escalas Brinell e Rockwell C dos três AIDs em estudo. A conversão dos valores de dureza Brinell à escala Vickers foi calculada como indica a norma ASTM E140-12 ${ }^{97 .}$

Tabela 4-10. Especificações da dureza máxima dos AIDs em estudo, seguindo a *ASTM A240-15 $69 \mathrm{e}^{* *}$ ASTM E140-12 ${ }^{97}$.

\begin{tabular}{|c|c|c|c|}
\hline AIDs & $\begin{array}{c}\text { *Dureza, } \text { max } \\
\text { [HB] }\end{array}$ & $\begin{array}{c}\text { *Dureza, max } \\
\text { [HRC] }\end{array}$ & ${ }^{* *}$ Microdureza, HV \\
\hline S32304 (2304) & 290 & 32 & 305 \\
\hline S32205 (SAF 2205) & 293 & 31 & 309 \\
\hline S32750 (SAF 2507) & 310 & 32 & 327 \\
\hline
\end{tabular}


A aplicação do teste de microdureza Vickers é recomendado para camadas superficiais, folhas finas, arames, fases microscópicas e ZTAs em soldas ${ }^{96}$.

Foram realizados dos tipos de testes de microdureza Vickers. O primeiro foi o ensaio HV1, que aplica uma carga de $1000 \mathrm{gf}(9,807 \mathrm{~N})$ durante $10 \mathrm{~s}$. Esta carga deixa uma indentação que permite medir a dureza dos aços e ZTAs simuladas. O segundo ensaio foi o HV0.01 ${ }^{98}$ que aplica uma carga de $10 \mathrm{gf}(98,07 \mathrm{mN})$ durante $10 \mathrm{~s}$, por usar uma carga menor foi usado para medir a dureza de cada uma das fases presentes nos aços na condição de como-recebido e as ZTAs simuladas.

Os ensaios HV1 e HV0.01 foram realizados no microdurómetro de marca Shimadzu e modelo HMV-Microhardness Tester de acordo com a norma ASTM E384-16 99. Este equipamento é automatizado e fornece o valor da microdureza calculado em escala $H V$ (Vickers Hardness Number) seguindo a Equação 4-3 98 99.

$H V=1854,4 \frac{P}{d^{2}}$

Equação 4-3

Onde:

$P=$ Carga,$[g f]$

$d=$ Largura da média das diagonais das indentações, $[\mu \mathrm{m}]$

Incialmente foram realizadas indentações em HV1 nas amostras e subsequentemente foram realizadas indentações nas fases ferrita e austenita individualmente com HV0.01.

Essas indentações foram realizadas para todas as condições estudadas com uma média de 5 indentações para cada uma das regiões de interesse. As cinco medidas foram realizadas para obter uma abordagem estatística da microdureza das amostras, calculando para cada uma delas: a média, o desvio padrão e o erro.

As medidas de microdureza foram correlacionadas com os três AIDs em estudo e os aportes de calor usados na simulação das ZTAs. 
5

\section{Resultados}

5.1.

\section{Análise Química}

Na Tabela 5-1 é apresentada a composição química para cada um dos três AIDs em estudo, obtida por análise química instrumental, em duplicata via espectroscopia de emissão ótica seguindo a norma ASTM A751-11 70. Nessa tabela estão mostrados os 10 elementos especificados pela norma ASTM A240$15^{69}$, para este tipo de aço inoxidável. Além foi realizado um re-teste destas análises com novas amostras tomadas dos mesmos aços o que permitiu conferir os resultados.

As análises químicas detectaram além outros elementos na composição dos aços como alumínio, cobalto, titânio, nióbio, vanádio, tungstênio, chumbo, boro, estanho, arsênio, bismuto e cálcio. Os resultados completos das análises químicas são apresentados no Apêndice.

Tabela 5-1. Composição química dos aços estudados, analise obtida seguindo a norma ASTM A751-11 ${ }^{70}$, porcentagem em massa (\%).

\begin{tabular}{|c|c|c|c|c|c|c|c|c|c|c|}
\hline Elemento & $\mathbf{C}$ & $\mathbf{C r}$ & $\mathbf{N i}$ & $\mathbf{M o}$ & $\mathbf{M n}$ & $\mathbf{P}$ & $\mathbf{S}$ & $\mathbf{S i}$ & $\mathbf{C u}$ & $\mathbf{N}$ \\
\hline $\begin{array}{c}\mathbf{S} 32304 \\
\mathbf{( 2 3 0 4 )}\end{array}$ & $\mathbf{0 , 0 2 7}$ & $\mathbf{2 3 , 0 9}$ & $\mathbf{4 , 9 6}$ & $\mathbf{0 , 1 8 2}$ & $\mathbf{1 , 3 8}$ & $\mathbf{0 , 0 2 6}$ & $\mathbf{0 , 0 0 4 2}$ & $\mathbf{0 , 3 3 8}$ & $\mathbf{0 , 4 3 3}$ & $\mathbf{0 , 1 2}$ \\
\cline { 2 - 11 } & 0,028 & 26,20 & 5,02 & 0,179 & 1,62 & 0,018 & 0,0038 & 0,398 & 0,395 & 0,11 \\
\hline $\begin{array}{c}\text { S32205 } \\
\text { (SAF 2205) }\end{array}$ & $\mathbf{0 , 0 2 5}$ & $\mathbf{2 2 , 4 8}$ & $\mathbf{5 , 2 1}$ & $\mathbf{3 , 2 5}$ & $\mathbf{0 , 8 2}$ & $\mathbf{0 , 0 2 7}$ & $\mathbf{0 , 0 0 4 1}$ & $\mathbf{0 , 4 9 8}$ & $\mathbf{0 , 1 3 2}$ & $\mathbf{0 , 4 0}$ \\
\cline { 2 - 11 } & 0,027 & 22,87 & 5,25 & 3,16 & 0,88 & 0,023 & 0,0041 & 0,477 & 0,137 & 0,42 \\
\hline $\begin{array}{c}\text { S32750 } \\
\text { (SAF 2507) }\end{array}$ & $\mathbf{0 , 0 2 2}$ & $\mathbf{2 5 , 8 1}$ & $\mathbf{6 , 4 2}$ & $\mathbf{3 , 9 3}$ & $\mathbf{0 , 5 0}$ & $\mathbf{0 , 0 2 6}$ & $\mathbf{0 , 0 0 4 3}$ & $\mathbf{0 , 3 0 0}$ & $\mathbf{0 , 1 4 8}$ & $\mathbf{0 , 2 5}$ \\
\cline { 2 - 11 } & 0,038 & 25,69 & 6,55 & 3,79 & 0,54 & 0,025 & 0,0048 & 0,277 & 0,152 & 0,22 \\
\hline
\end{tabular}

O PRE (PREw) foi calculado, a partir de composição química obtida para os três aços AIDs em estudo (Tabela 5-1) de acordo com a Equação 3-4 como mostrado na Tabela 5-2. 
Tabela 5-2. Cálculo do PREw nos AIDs.

\begin{tabular}{|c|c|c|c|}
\hline & $\begin{array}{c}\text { UNS S32304 } \\
(2304)\end{array}$ & $\begin{array}{c}\text { UNS S32205 } \\
\text { (SAF 2205) }\end{array}$ & $\begin{array}{c}\text { UNS S32750 } \\
\text { (SAF 2507) }\end{array}$ \\
\hline PRE $_{w}$ & 25,6 & 39,6 & 42,8 \\
\hline
\end{tabular}

\section{2.}

\section{Simulação no Software Thermo-Calc}

O uso da base de dados TCFE3 do software Thermo-Calc está limitado pelo teor dos elementos de liga. As composições químicas dos três aços em estudo não excederam estes teores. Portanto, foram construídos os diagramas de fases para os três aços utilizando os resultados completos das primeiras análises químicas realizadas.

As Figuras 5-1, 5-2 e 5-3 apresentam os diagramas de fase para os três aços indicando em função da temperatura as fases que estariam presentes em condições de equilíbrio.

A partir destes diagramas de fase foi selecionada a temperatura de pico usada em todas as simulações físicas na Gleeble. A temperatura de pico de $1350^{\circ} \mathrm{C}$ executada durante as simulações das ZTAs na Gleeble permitiu assegurar a ferritização completa nos três aços sem chegar a fase líquida (Tabela 5-3).

Tabela 5-3. Temperaturas do balance de fases Austenita-Ferrita próximo 50:50 e temperatura de completa ferritização.

\begin{tabular}{|c|c|c|}
\hline AID & $\begin{array}{c}\text { Temperatura de Equilíbrio 50:50 } \\
\text { de Ferrita-Austenita }\left[{ }^{\circ} \mathbf{C}\right]\end{array}$ & $\begin{array}{c}\text { Temperatura de Ferritização } \\
\text { Completa }\left[{ }^{\circ} \mathbf{C}\right]\end{array}$ \\
\hline UNS S32304 & 1126 & $1329-1359$ \\
\hline UNS S32205 & 1275 & $1319-1352$ \\
\hline UNS S32750 & 989 & $1294-1357$ \\
\hline
\end{tabular}




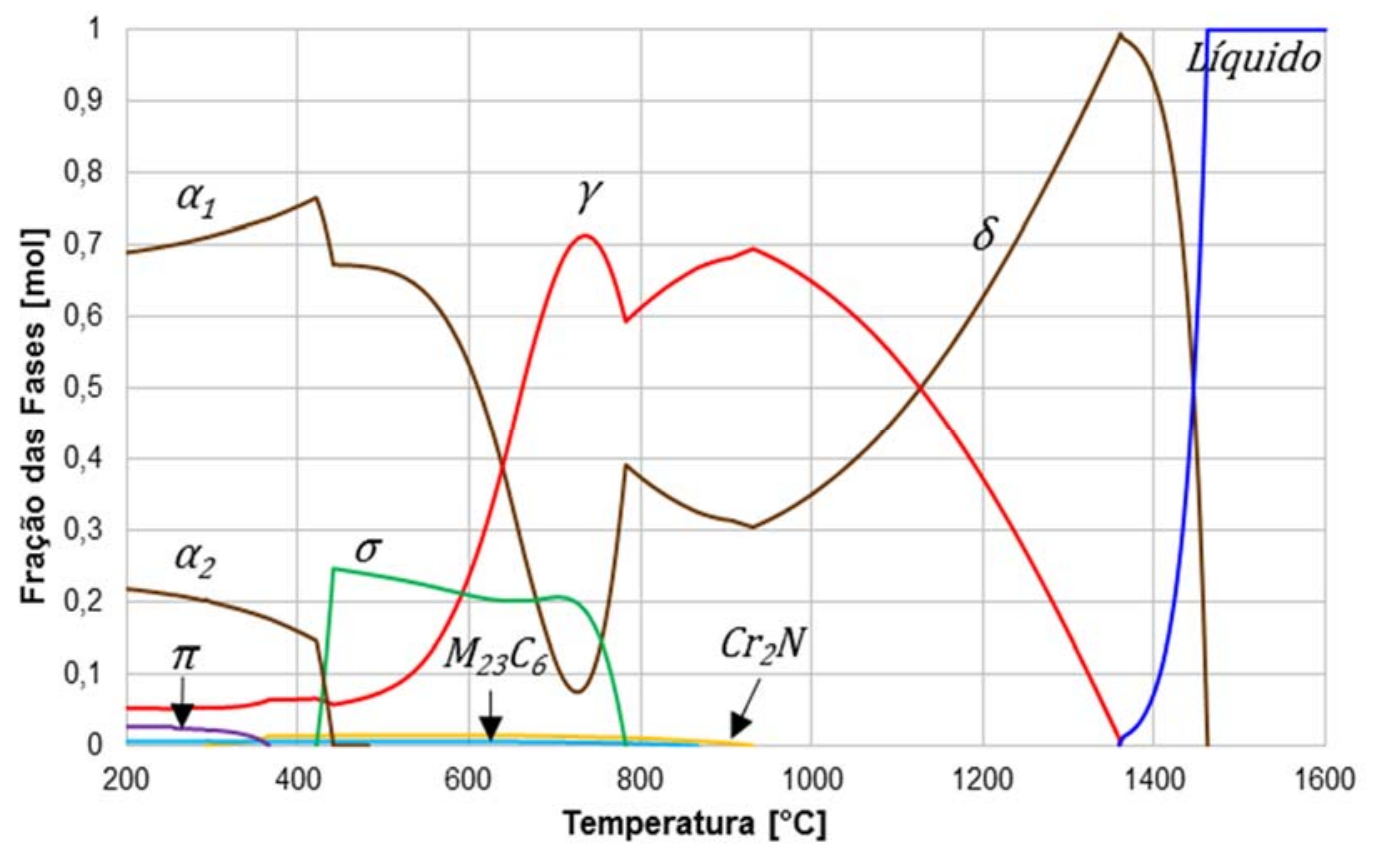

Figura 5-1. Frações de fase previstas para o aço inoxidável lean duplex UNS S32304 (2304).

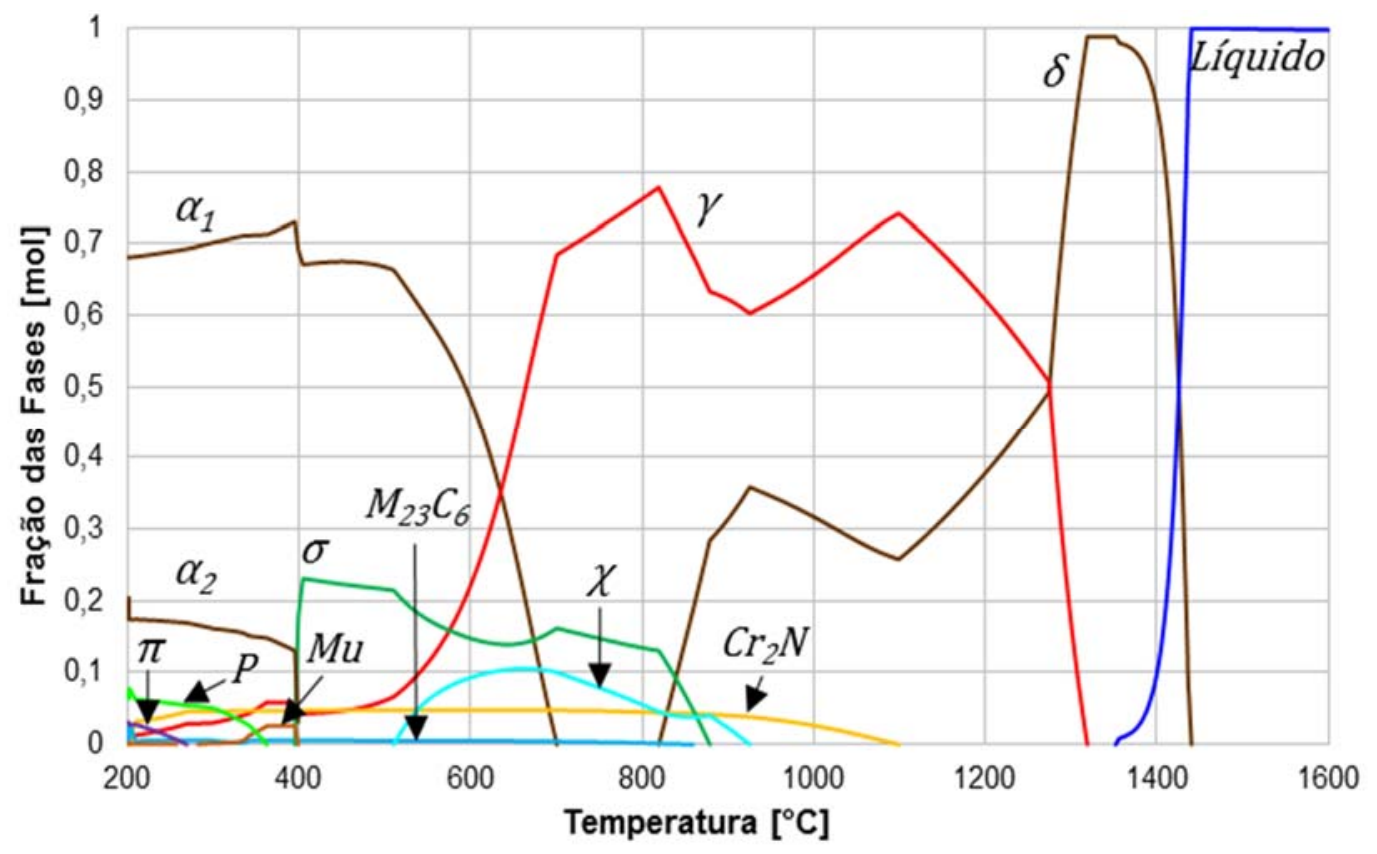

Figura 5-2. Frações de fase previstas para o aço inoxidável duplex UNS S32205 (2205). 


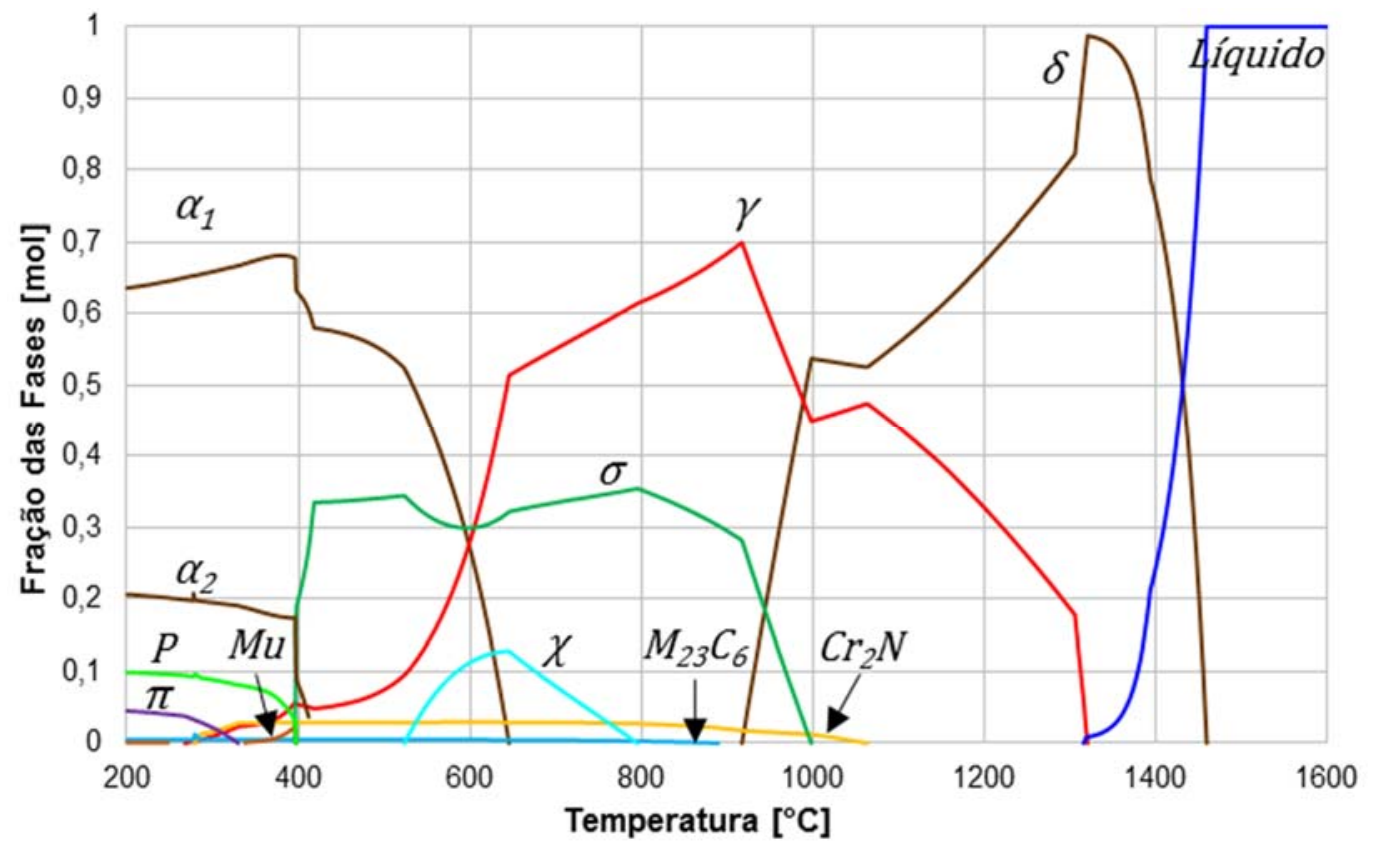

Figura 5-3. Frações de fase previstas para o aço inoxidável duplex UNS S32750 (2507).

De acordo com a base de dados TCFE3, é apresentado na Tabela 5-4 a composição de cada uma das fases identificadas nos diagramas (frações de fases vs temperatura) para cada um dos aços estudados. O símbolo \# é usado para denotar a diferentes composições definidas para a mesma fase ${ }^{72}$. 
Tabela 5-4. Composição das fases identificadas ${ }^{72}$.

\begin{tabular}{|l|l|}
\hline Fase & Composição da Fase \\
\hline $\begin{array}{l}\text { BCC_A2 } \\
\text { (Ferrita })\end{array}$ & $(\text { Al Ca Ce Co Cr Cu Fe Mg Mn Mo Nb Ni P S Si Ta Ti V W Y Zn Zr })_{1}(\mathrm{~B} \mathrm{C} \mathrm{N} \mathrm{O} \mathrm{Va})_{3}$ \\
\hline $\begin{array}{l}\text { FCC_A1 } \\
\text { (Austenita) }\end{array}$ & $(\text { Al Ca Ce Co Cr Cu Fe Mg Mn Mo Nb Ni P S Si Ta Ti V W Y Zn Zr })_{1}(\mathrm{~B} \mathrm{C} \mathrm{N} \mathrm{O} \mathrm{Va})_{1}$ \\
\hline MNS & $(\text { Ca Cr Cu Fe Mg Mn })_{1}(\mathrm{~S})_{1}$ \\
\hline HCP_A3\#2 & $(\text { Al Ca Ce Co Cr Cu Fe Mg Mn Mo Nb Ni P S Si Ta Ti V W Y Zn Zr })_{1}(\mathrm{~B} \mathrm{C} \mathrm{N} \mathrm{O} \mathrm{Va})_{0.5}$ \\
\hline M23C6 & $(\mathrm{Co} \mathrm{Cr} \mathrm{Fe} \mathrm{Mn} \mathrm{Ni} \mathrm{V})_{20}(\mathrm{Co} \mathrm{Cr} \mathrm{Fe} \mathrm{Mn} \mathrm{Mo} \mathrm{Ni} \mathrm{V} \mathrm{W})_{3}(\mathrm{~B} \mathrm{C})_{6}$ \\
\hline M3P & $(\mathrm{Cr} \mathrm{Cu} \mathrm{Fe} \mathrm{Ni})_{2}(\mathrm{P})_{1}$ \\
\hline SIGMA & $(\mathrm{Al} \mathrm{Co} \mathrm{Cr} \mathrm{Fe} \mathrm{Mn} \mathrm{Ni} \mathrm{Ta} \mathrm{V})_{10}(\mathrm{Cr} \mathrm{Mo} \mathrm{Nb} \mathrm{Ta} \mathrm{Ti} \mathrm{V} \mathrm{W})_{4}(\mathrm{Al} \mathrm{Co} \mathrm{Cr} \mathrm{Fe} \mathrm{Mn} \mathrm{Mo} \mathrm{Nb} \mathrm{Ni} \mathrm{Si} \mathrm{Ta} \mathrm{Ti}$ \\
\hline FCC_A1\#2 $)_{16}$
\end{tabular}

\section{3.}

\section{Simulação Física na Gleeble}

Na Figura 5-4 são apresentadas as nove curvas programadas (em azul) e executadas (vermelho) durante a simulação das ZTAs do aço inoxidável lean duplex UNS S32304 (2304). As quatro curvas à esquerda da tabela são as curvas do primeiro grupo de corpos de prova com aportes de calor de 1,5, 2,0, 2,5 e 3,0 $\mathrm{kJ} / \mathrm{mm}$ e têmpera com água a $500^{\circ} \mathrm{C}$; e as cinco curvas à direta da tabela correspondem ao segundo grupo de corpos de prova com aportes de calor de 1,0, $1,5,2,0,2,5$ e $3,0 \mathrm{~kJ} / \mathrm{mm}$ e têmpera a $250^{\circ} \mathrm{C}$.

Além das curvas, foram calculados os tempos $\Delta t_{8 / 5}$ e $\Delta t_{12 / 8}$ para cada uma das curvas executas. As médias do $\Delta t_{8 / 5}$ e do $\Delta t_{12 / 8}$ foram calculadas para cada set de corpos de prova com as mesmas condições de simulação.

Da mesma maneira as Figuras 5-5 e 5-6 apresentam as curvas programadas e executadas das simulações das ZTAs no aço inoxidável duplex UNS S32205 (2205) e no aço inoxidável super duplex UNS S32750 (2507) respectivamente, 
assim como as médias dos tempos $\Delta t_{8 / 5}$ e $\Delta t_{12 / 8}$ para cada conjunto de corpos de prova com as mesmas condições de simulação.

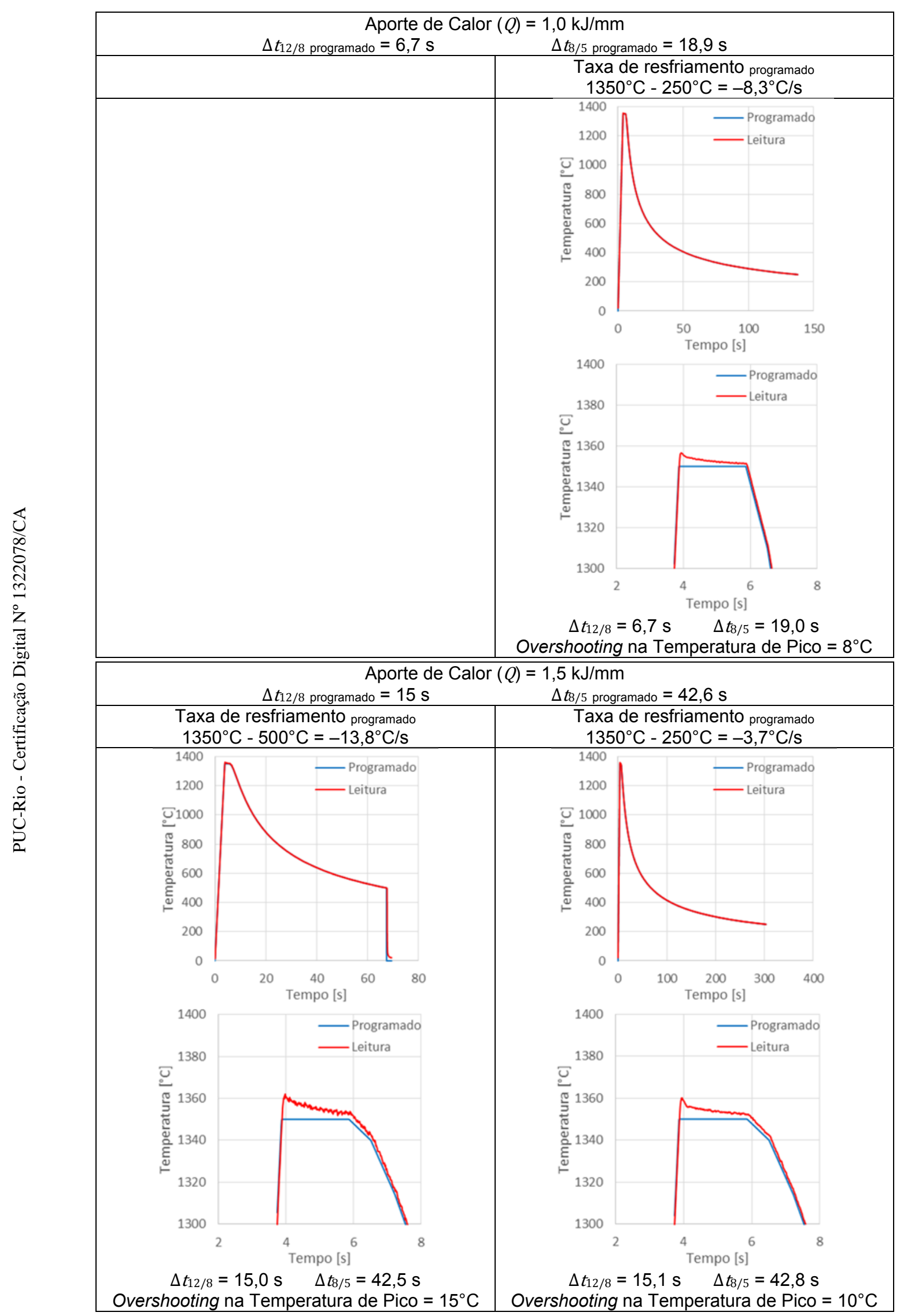




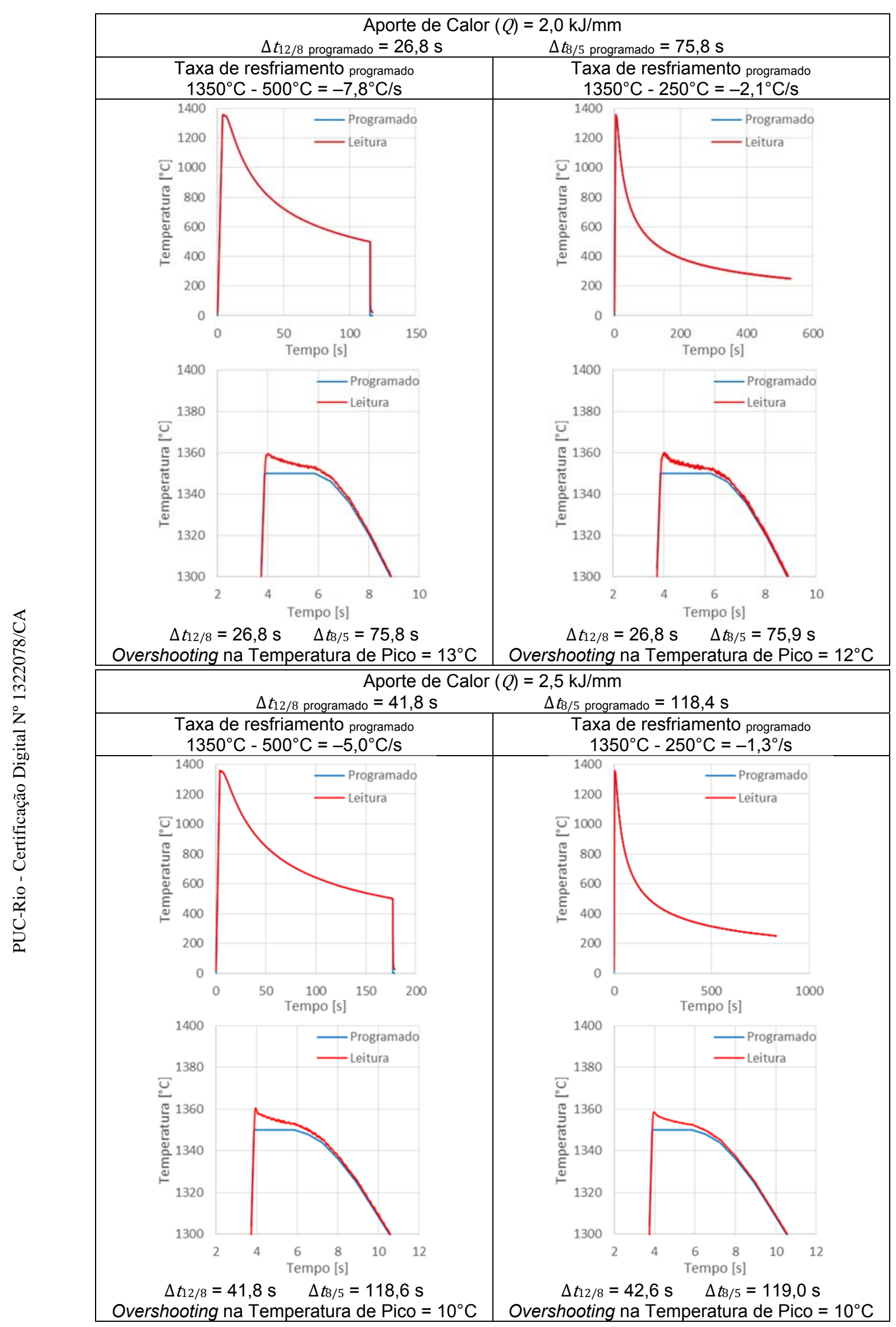




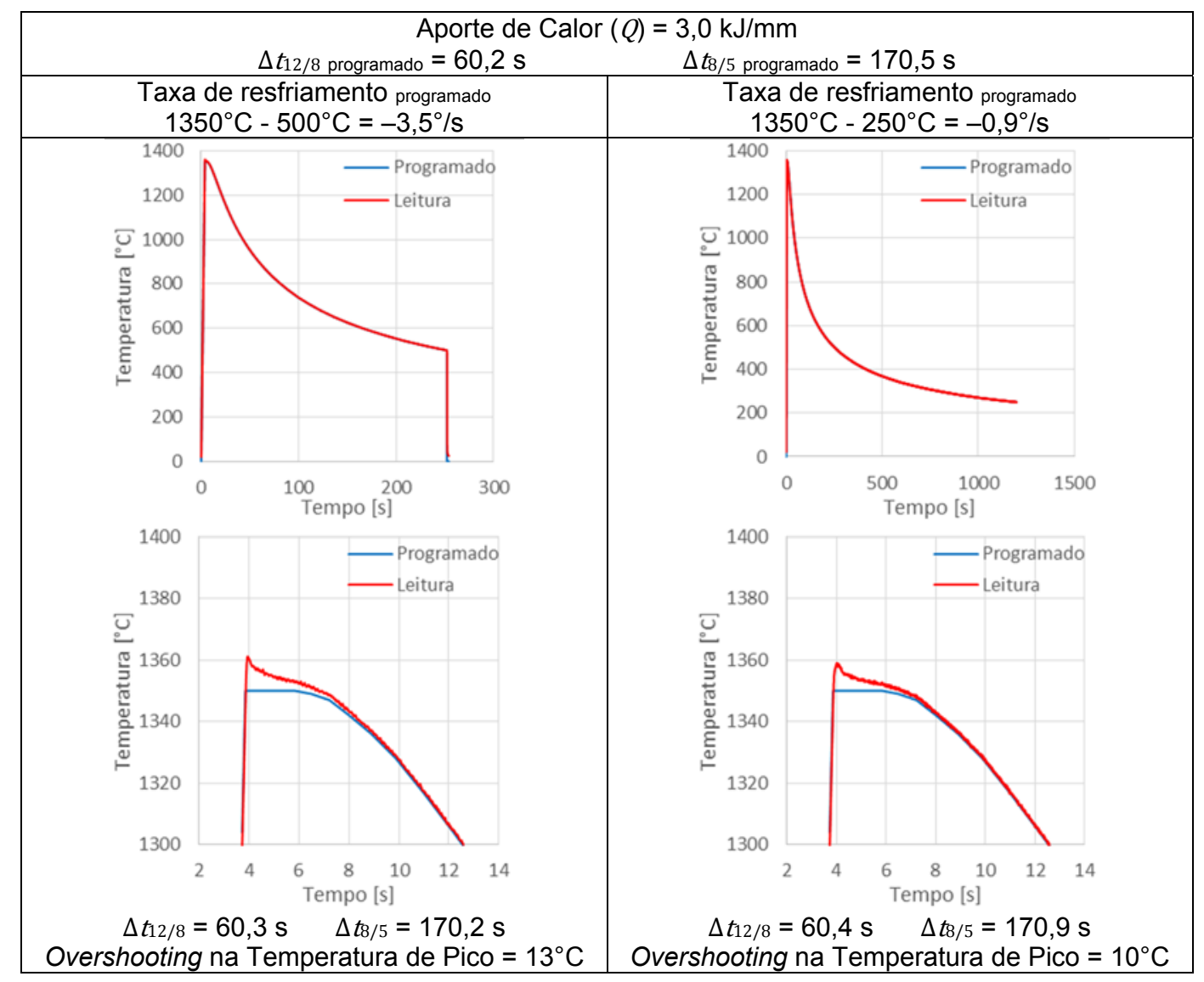

Figura 5-4. As nove curvas da simulações das ZTAs executadas no aço UNS S32304 (2304).

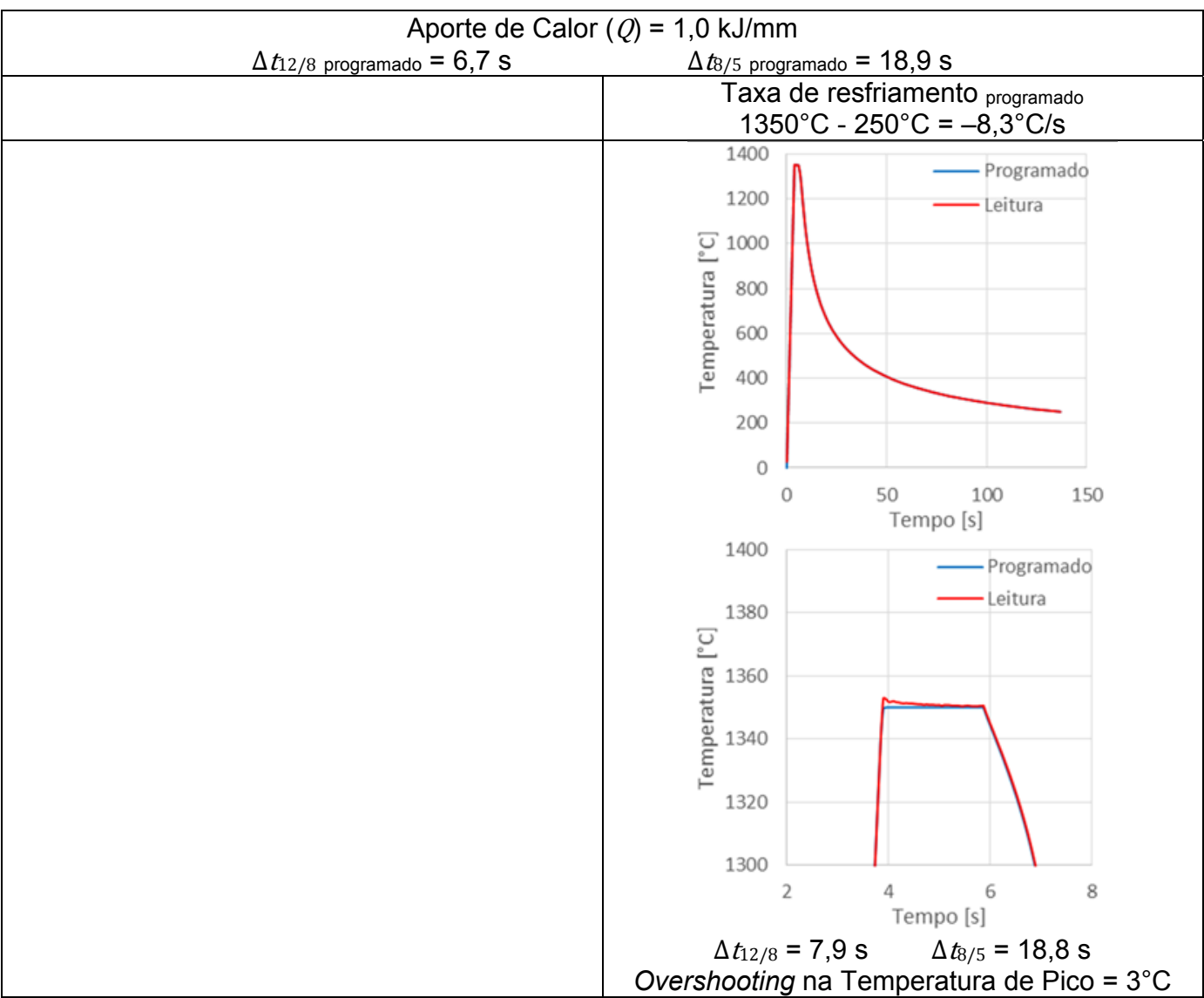




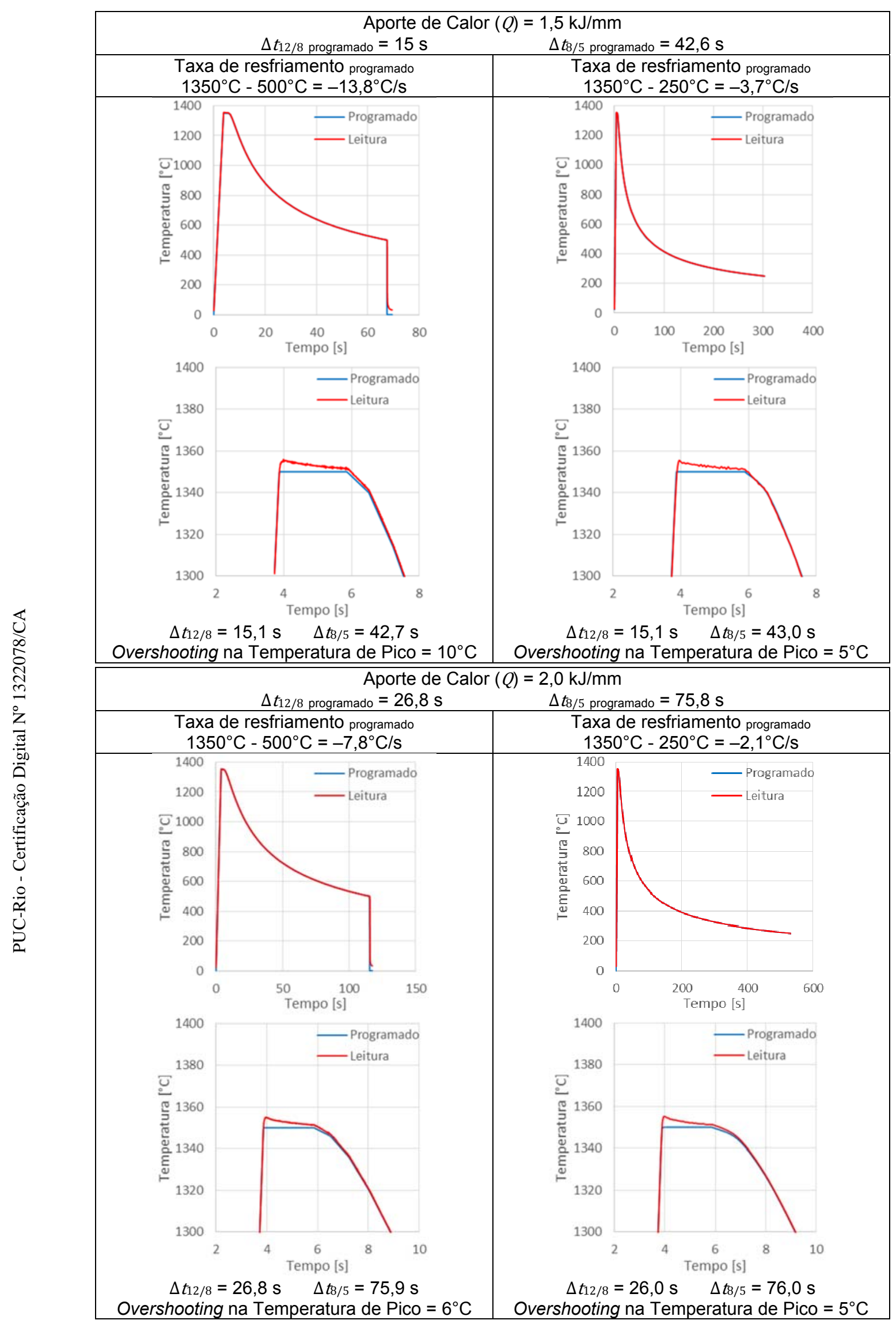




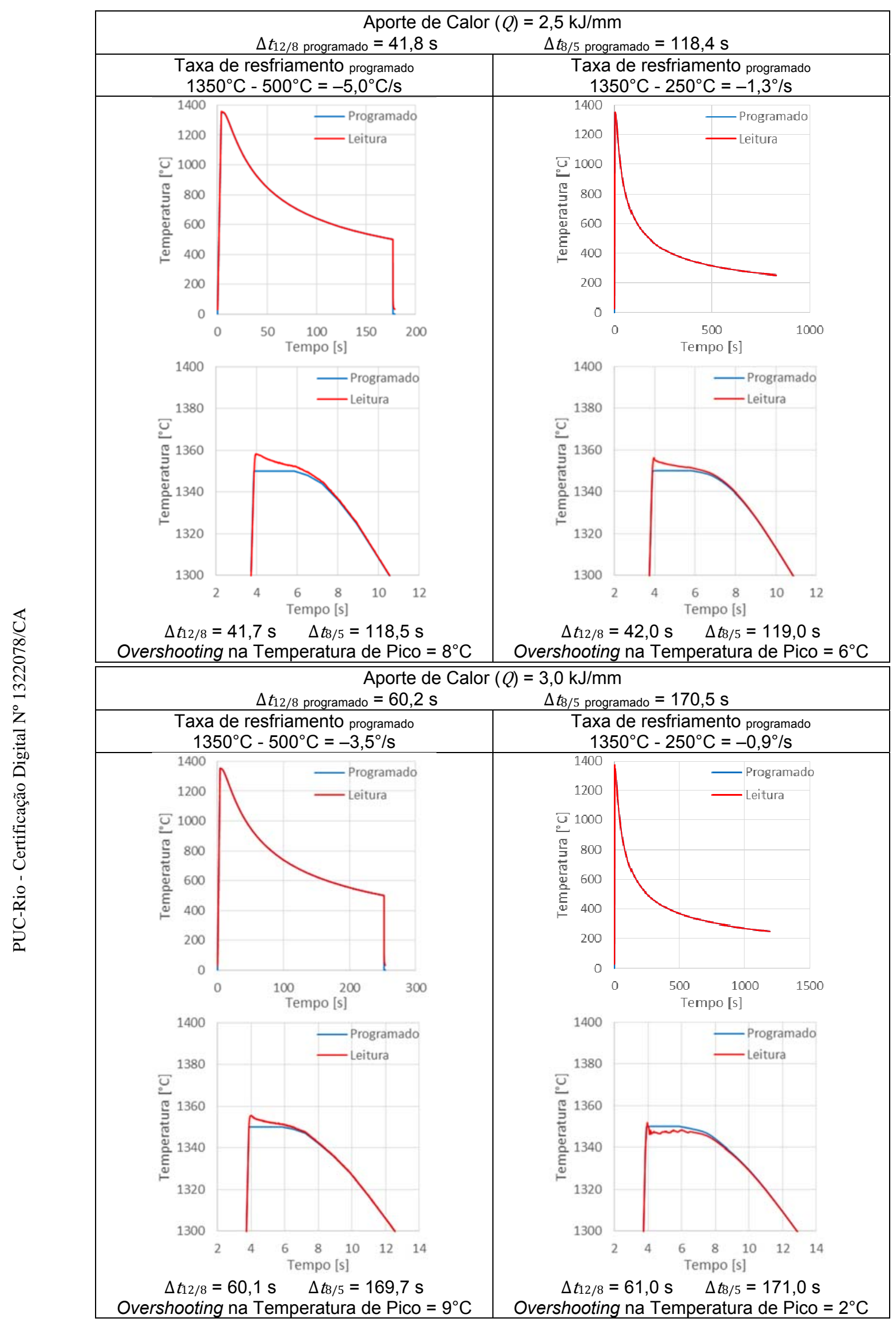

Figura 5-5. As nove curvas da simulações das ZTAs executadas no aço UNS S32205 (2205). 


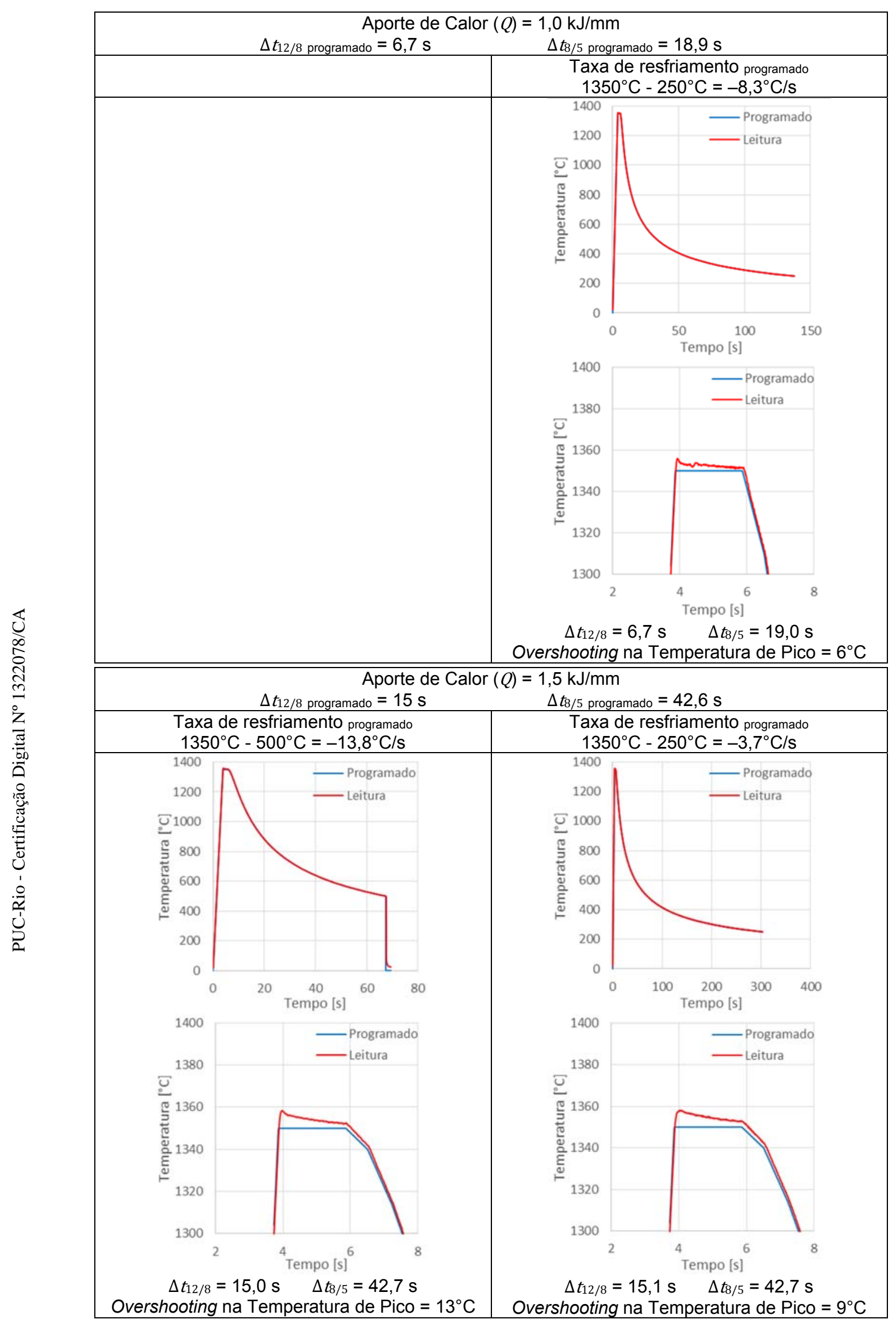




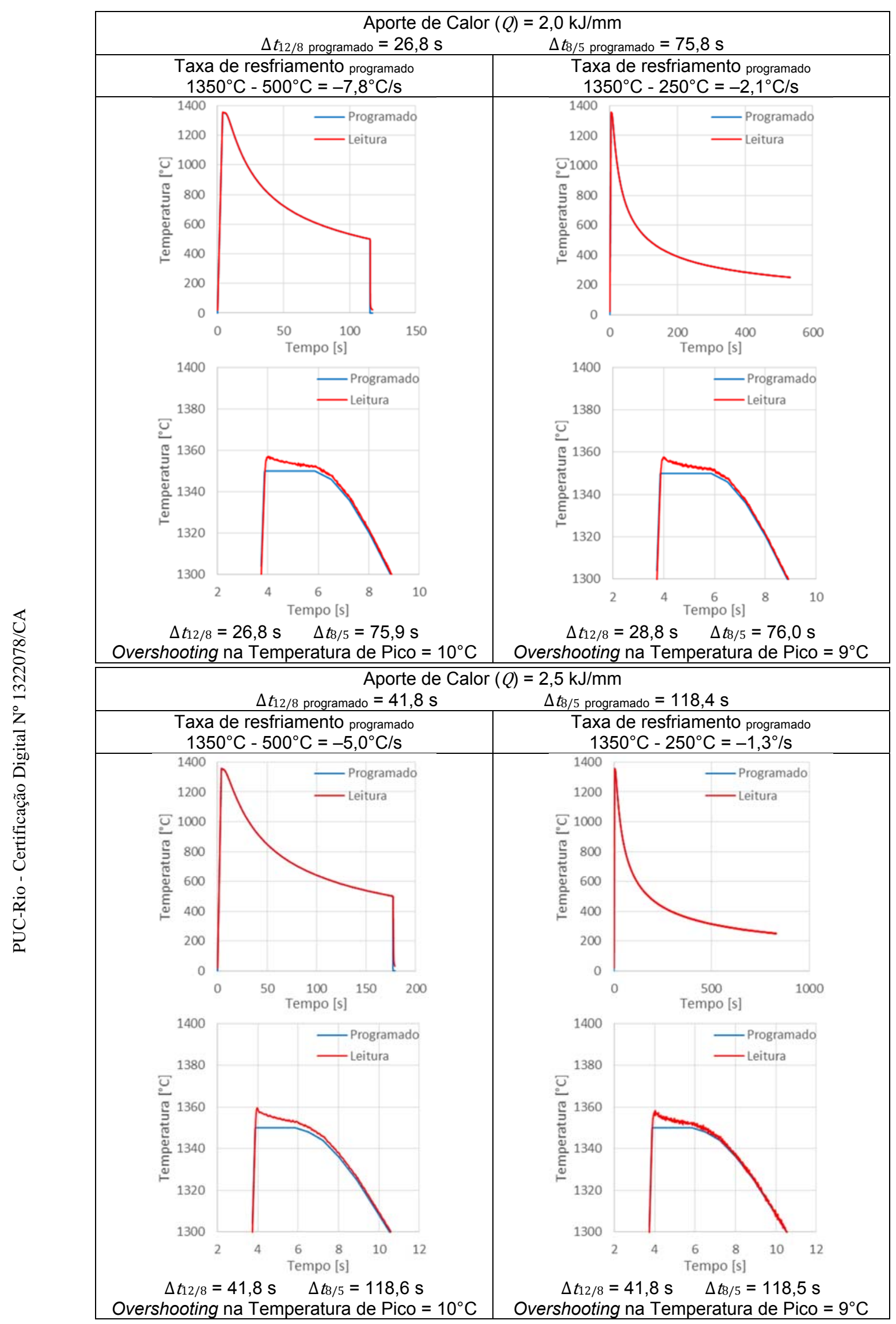




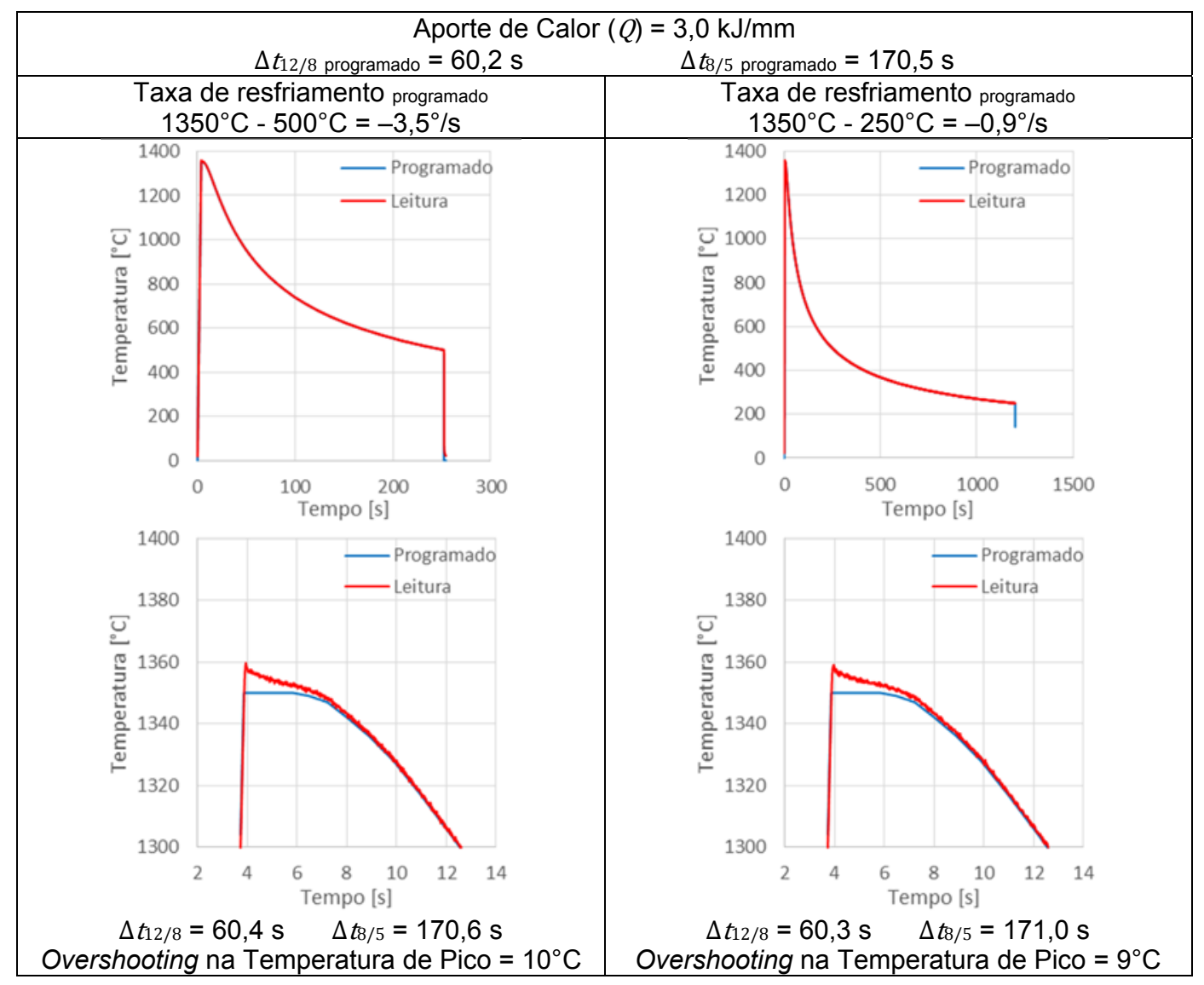

Figura 5-6. As nove curvas da simulações das ZTAs executadas no aço UNS S32750 (2507).

\section{4 . \\ Caraterização Metalográfica}

Foram utilizados dois ataques em sequência, o primeiro foi o ataque químico com solução Beraha modificada durante $8 \mathrm{~s}$ e o segundo foi o ataque eletrolítico com solução de $\mathrm{NaOH}$ ao $50 \%$ com $3 \mathrm{~V}$ durante $10 \mathrm{~s}$ para o aço inoxidável duplex UNS S32205 na condição de como-recebido. Este procedimento permitiu comparar o efeito dos ataques ao revelar as fases da austenita e ferrita e, consequentemente, permitiu selecionar $\mathrm{o}$ ataque que oferece melhor contraste $\mathrm{e}$ assim facilitar o processamento digital de imagens para a contagem de fases. $\mathrm{Na}$ Figura 5-7 são apresentadas as micrografias com os dois ataques.

$\mathrm{O}$ ataque químico com solução Beraha revela os contornos de grão e preferencialmente ataca a fase ferrítica. Esta reação do eletrólito com a ferrita pode ser identificada nas micrografias RGB (coloridas) com uma cor castanha avermelhada (terracota) ou azulada, por outro lado nas micrografias em branco e preto a ferrita aparece como uma cor cinza escura. No caso da austenita não se observa uma reação com o eletrólito (Figura 5-7 (a)). 
$\mathrm{O}$ ataque eletrolítico com solução de $\mathrm{NaOH}$ revela os contornos de grão e ataca preferencialmente a fase ferrítica. Esta reação não é homogénea, e os grãos de ferrita geram um gradiente de coloração cinza, enquanto que no caso da austenita observa-se uma leve reação com o eletrólito (Figura 5-7 (b)), o que não contribui é favoravelmente para o contraste das fases.

Comparativamente, o ataque químico com solução Beraha ofereceu melhor contraste nas micrografias e por isso foi utilizado para a identificação e a contagem de fases primárias (austenita e ferrita) por analise digital de imagem de todas as condições estudadas ${ }^{100 .}$

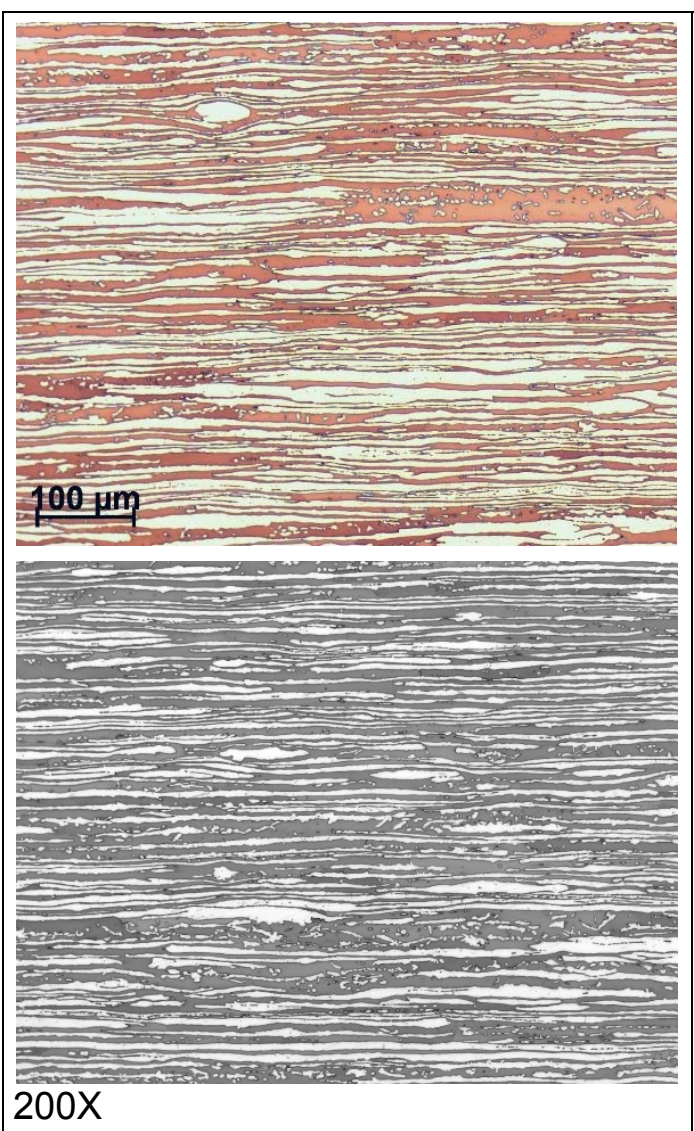

(a) Ataque químico com solução Beraha modificada.

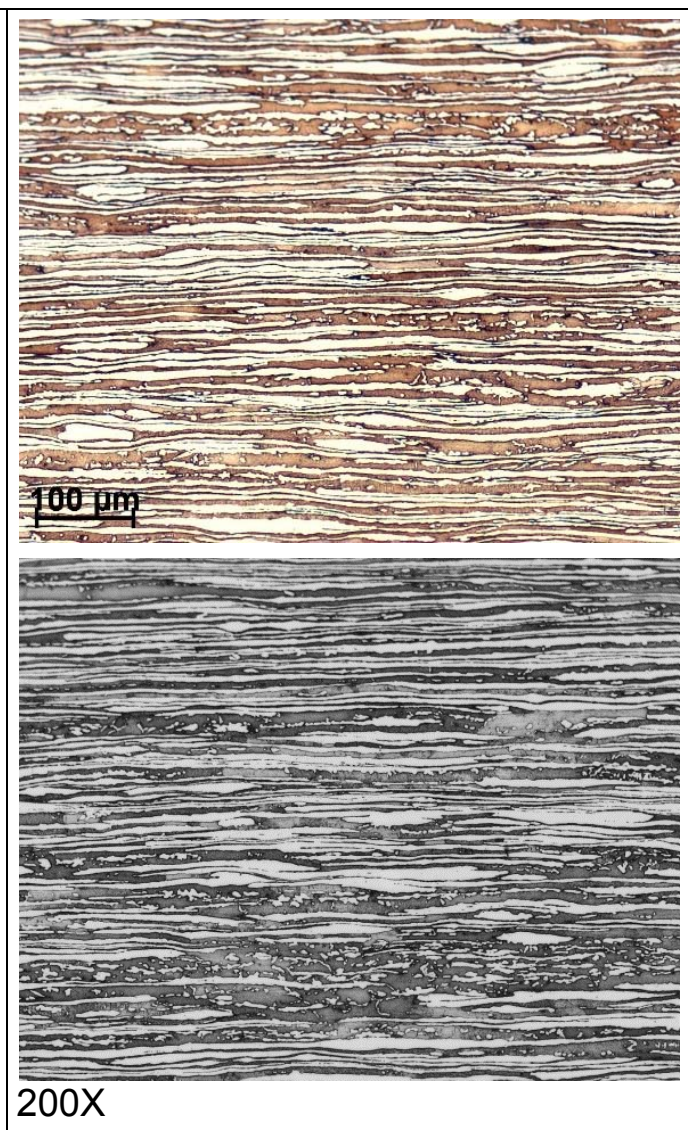

(b) Ataque eletrolítico com solução $40 \%$ de $\mathrm{NaOH}$.

Figura 5-7. Micrografias do aço inoxidável lean duplex 2304 na condição de como-recebido com os dois tipos de ataque. 


\subsection{1. Morfologia das Fases Primárias}

A micrografia mostrada na Figura 5-8 do aço inoxidável lean duplex UNS S32304 (2304) na condição de como-recebido, foi capturada com aumento de 500X e processada com ajuste de brilho e contraste automático (Brightness I Contrast) no Fiji Software. Nessa micrografia foram identificadas as fases de ferrita e austenita com morfologia alongada, além de austenita intragranular na matriz ferrítica.

A micrografia do aço inoxidável lean duplex UNS S32304 na condição de como-recebido mostrada Figura 5-8 exemplifica a morfologia alongada dos grãos de ferrita e austenita. Esta morfologia típica se apresenta nos três AIDs estudados na condição de como-recebido que foram submetidos a laminação durante os processo de fabricação da chapa de aço lean duplex UNS S2304 e dos tubos de aços duplex UNS S32205 e super duplex UNS S32750.

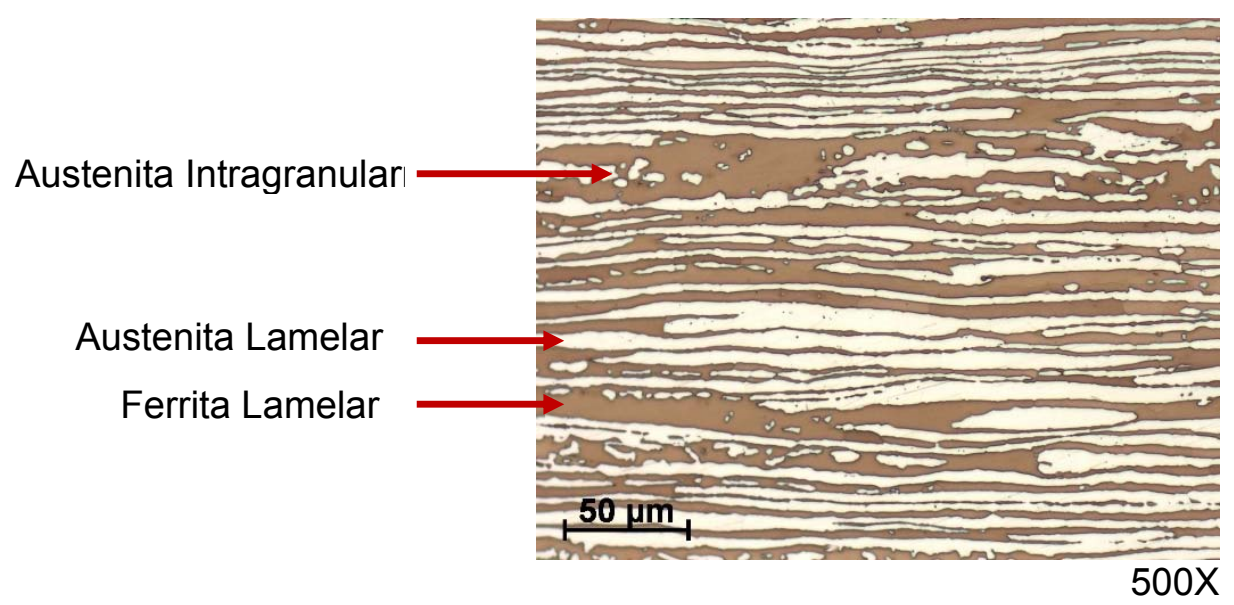

Figura 5-8. Micrografia do aço inoxidável lean duplex 2304. Superfície atacada quimicamente com solução Beraha modificada.

A morfologia obtida em todas as ZTAs simuladas correspondem à morfologia típicas das ZTAs em soldagem real. Para o aço lean duplex foi obtida uma ZTA de alta fração de ferrita (isso foi confirmado nas medições das contagens de fases) onde a espessura dos grãos de austenita nos contornos de grão da ferrita e fina (Figura 5-9).

A micrografia apresentada na Figura 5-9 exemplifica a morfologia das fases obtidas na ZTA simulada e corresponde ao aporte de calor de $2,5 \mathrm{~kJ} / \mathrm{mm}$ e têmpera em água a $500^{\circ} \mathrm{C}$ do aço inoxidável lean duplex UNS S32304. Durante a simulação da ZTA a ferrita lamelar se transforma em ferrita equiaxial e a 
austenita se precipita nos contornos e no interior do grão ferrítico, assim como também nos contornos de grão ferríticos com morfologia Widmanstätten. Observa-se, que a austenita intragranular exibe morfologia irregular.

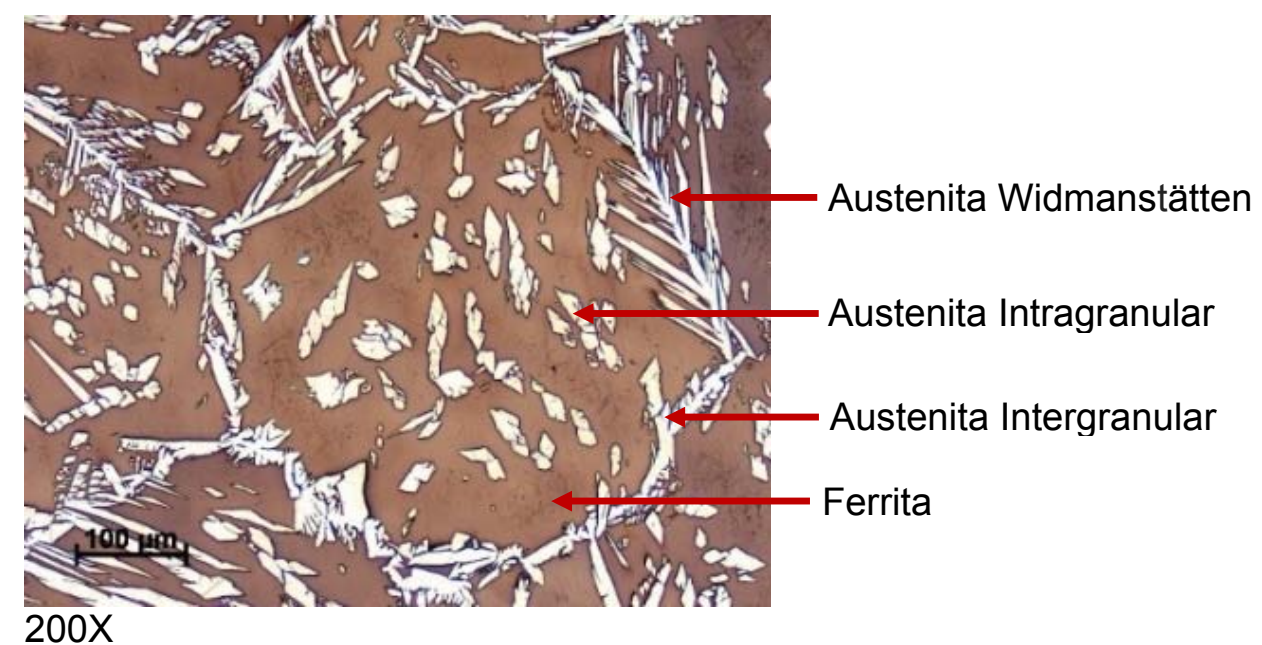

Figura 5-9. Micrografia do aço inoxidável lean duplex 2304. Superfície atacada quimicamente com solução Beraha modificada.

As Figuras 5-10, 5-11 e 5-12 apresentam de maneira organizada as micrografias com aumento de 200X para cada parâmetro da simulação da ZTA nos aços lean duplex UNS S32304, duplex UNS S32205 e super duplex UNS S32750 respectivamente. 


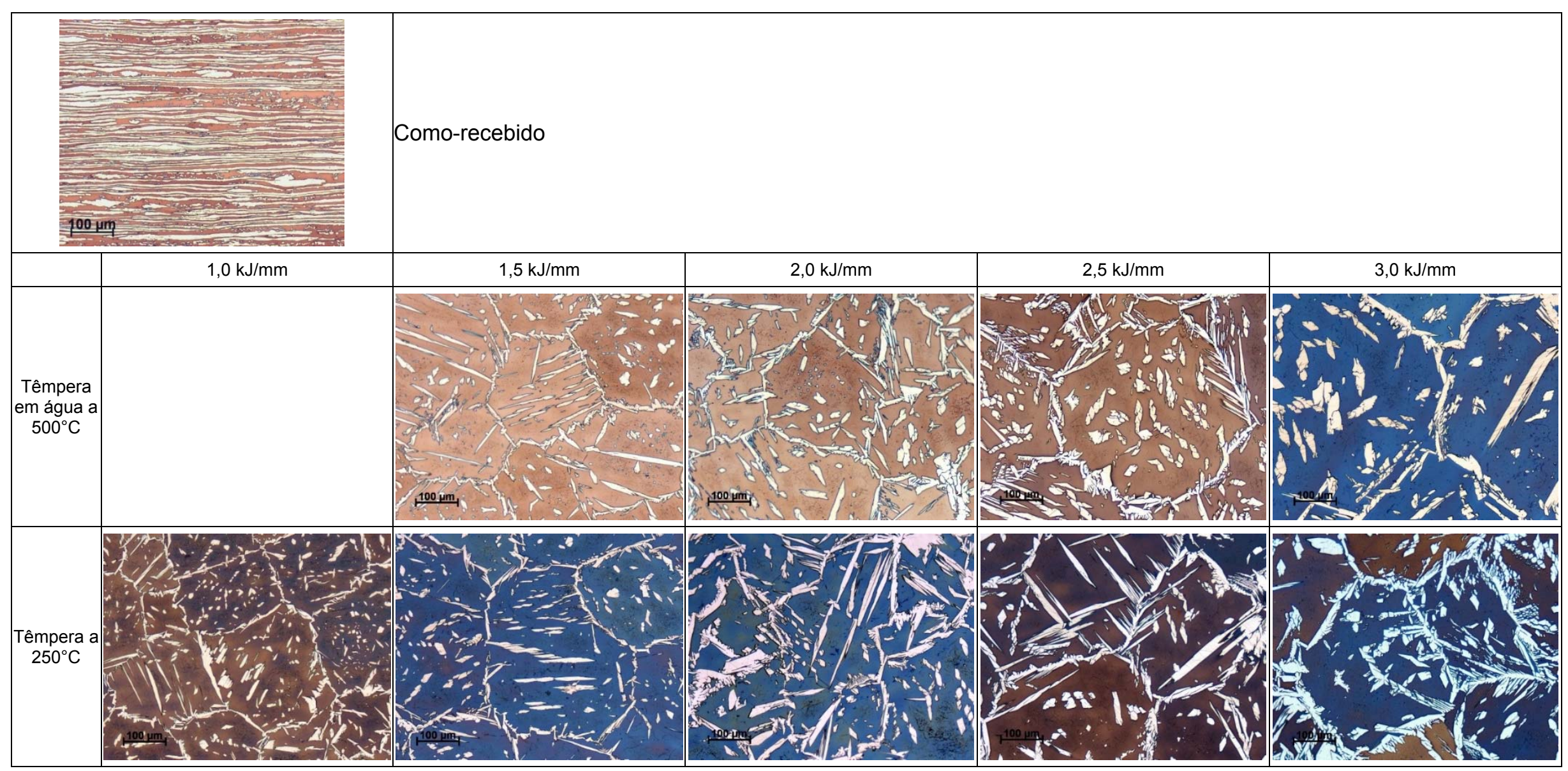

Figura 5-10. Micrografias do aço inoxidável lean duplex UNS S32304 na condição de como-recebido e das ZTAs simuladas com diferentes parâmetros de aporte de calor e têmpera. 


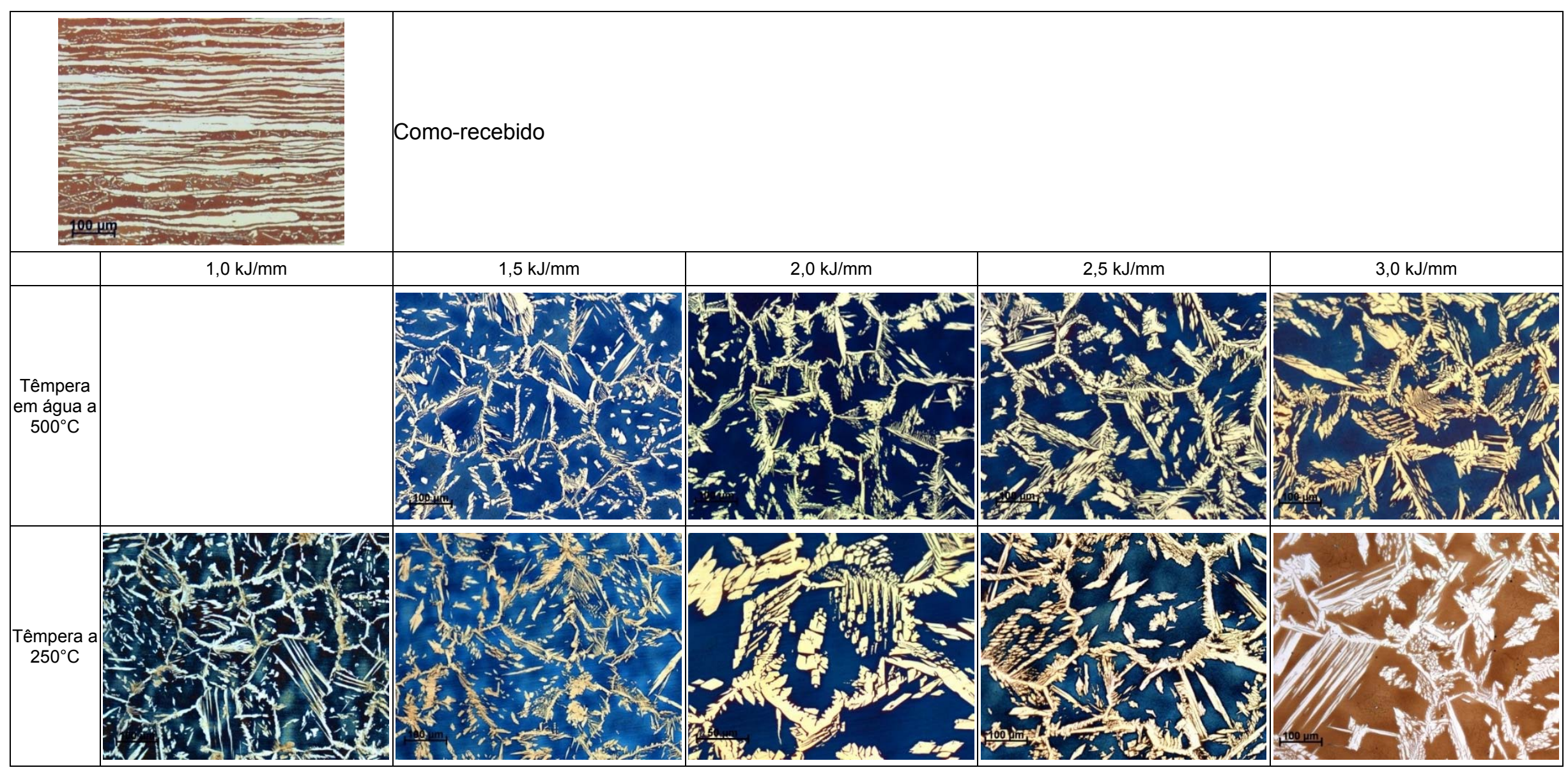

Figura 5-11. Micrografias do aço inoxidável duplex UNS S32205 na condição de como-recebido e das ZTAs simuladas com diferentes parâmetros de aporte de calor e têmpera. 


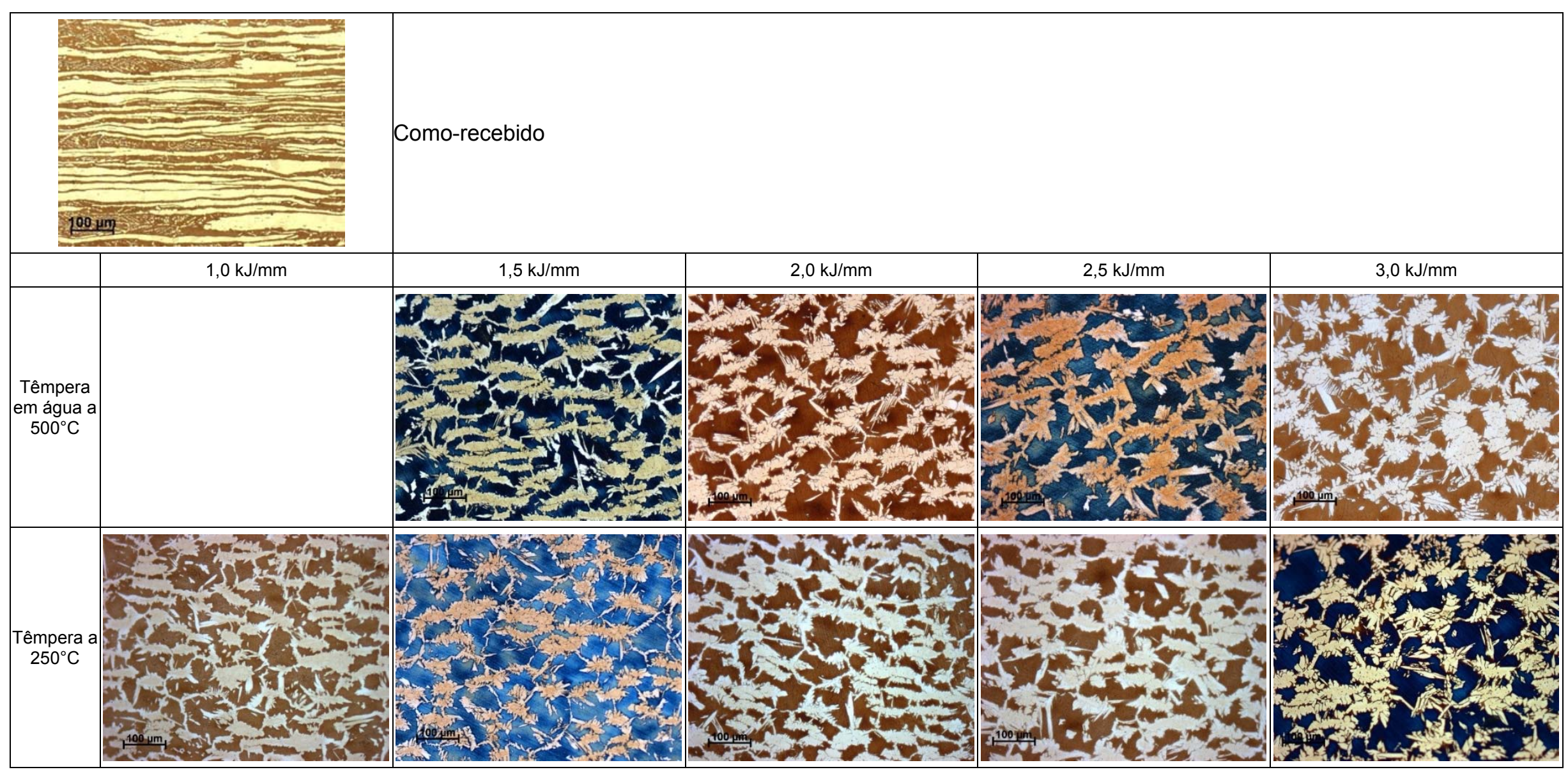

Figura 5-12. Micrografias do aço inoxidável super duplex UNS S32507 na condição de como-recebido e das ZTAs simuladas com diferentes parâmetros de aporte de calor e têmpera. 


\subsection{2. \\ Contagem de Fases}

Para realizar a contagem de fases, foram capturadas aproximadamente 20 imagens para cada amostra, em branco e preto, com aumento de 200X. As micrografias dos AIDs na condição de como-recebido e das ZTAs simuladas foram obtidas por microscopia ótica em campo claro.

\subsubsection{1.}

Aço Inoxidável Lean Duplex UNS S32304 (2304)

Para a contagem de fases foram capturadas 21 micrografias com aumento de $200 \mathrm{X}$, as quais permitiram identificar facilmente os grãos de austenita na matriz ferrítica (Figura 5-13).

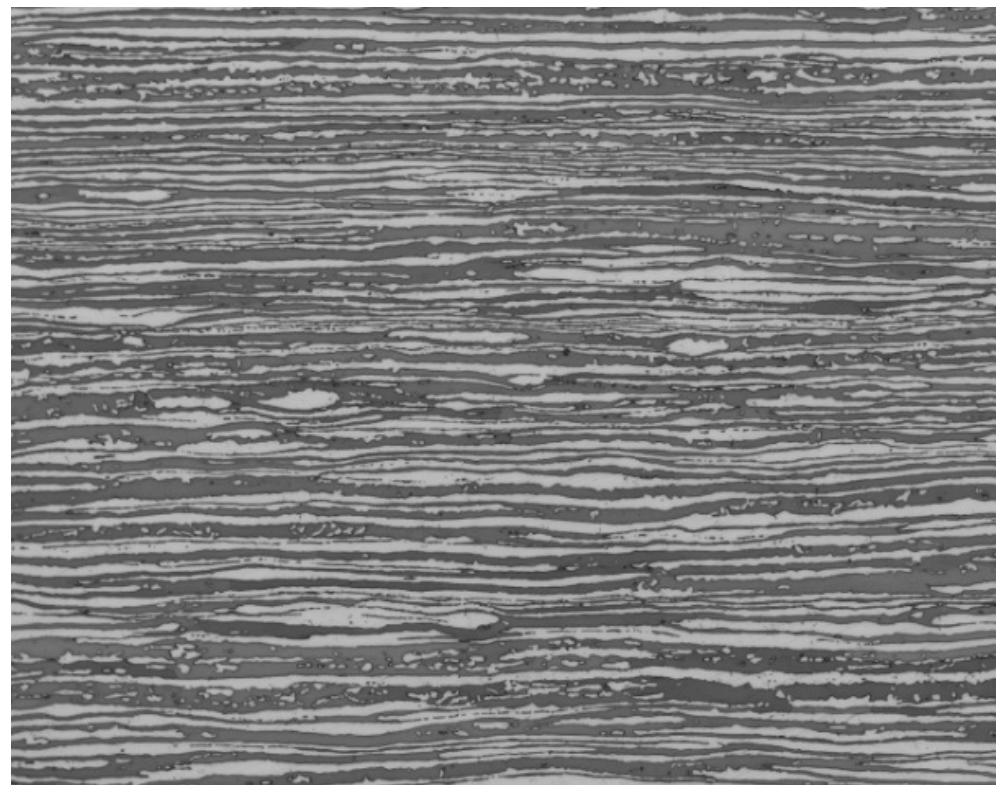

Figura 5-13. Micrografia típica do aço inoxidável lean duplex UNS S32304 na condição comorecebido com a superfície atacada quimicamente com solução Beraha modificada, capturada com aumento de 200X utilizada para a contagem de fases.

As imagens com aumento de 200X foram submetidas a um processamento digital prévio à contagem de fases onde foi corrigida a iluminação, a relação brilho / contraste, seguido de aplicação de filtros para a redução de ruído e identificação dos contornos de grão. Na Figura 5-14, a imagem (a) apresenta como exemplo a primeira micrografia a processar do grupo de 21 micrografias destinadas à contagem de fases do aço lean duplex UNS S32304. A imagem (b) apresenta a mesma micrografia após o processamento digital, seguida da imagem (c) que 
mostra a identificação dos grãos de austenita (região branca) e a imagem (d) onde é identificada a matriz ferrítica (região branca) mediante o Fiji Software.

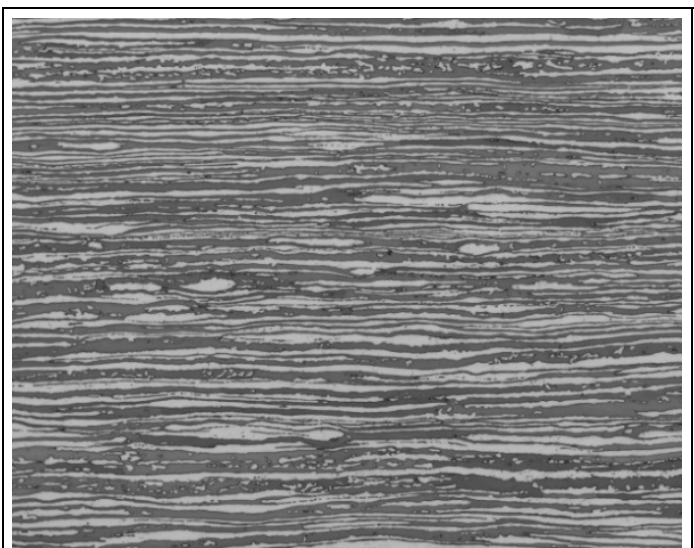

(a) Imagem com aumento de 200X destinada à contagem de fases.

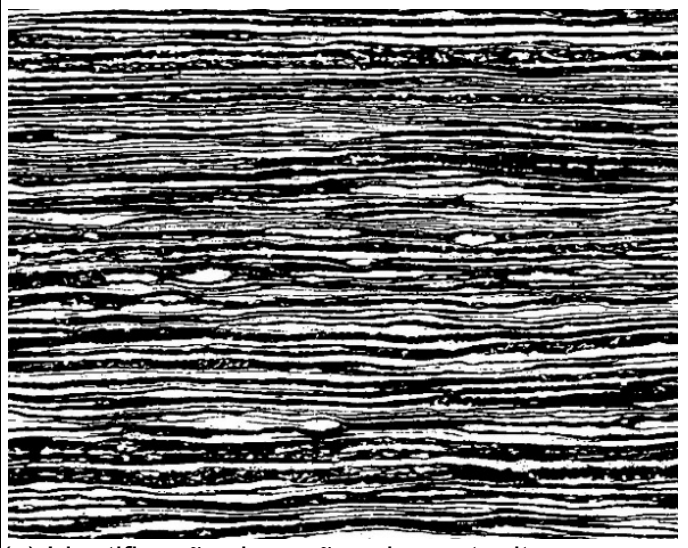

(c) Identificação dos grãos de austenita.

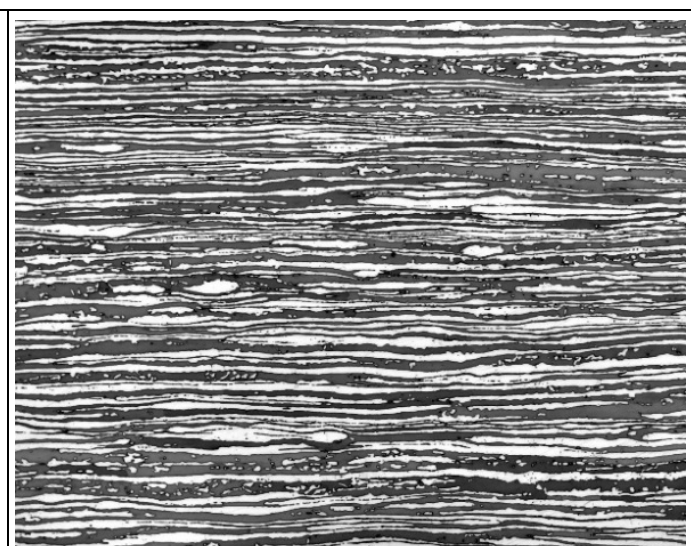

(b) Imagem processada no Fiji Software.

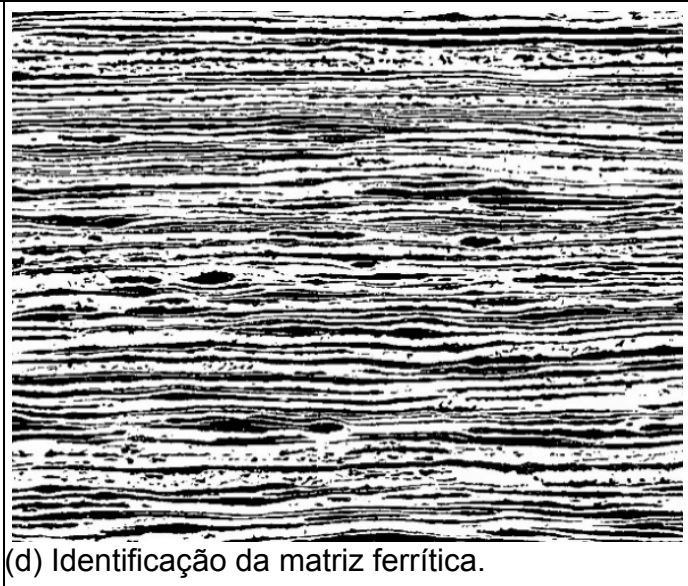

Figura 5-14. Exemplo de processamento e identificação da fases no aço inoxidável lean duplex UNS S32304.

Por meio da metodologia acima descrita foram calculadas as frações de áreas de 21 micrografias que correspondem às frações volumétricas. As médias e os erros destes valores foram calculados, $40,729 \% \pm 0,719 \%$ de austenita e $59,271 \% \pm 0,719 \%$ de ferrita como mostrado na Tabela $5-5$.

Tabela 5-5. Fração Volumétrica das fases calculadas pelo método de análise digital de imagem no aço inoxidável lean duplex UNS S32304 na condição de como-recebido, superfície atacada com solução Beraha Modificada. Erro calculado com 97,5\% de IC.

\begin{tabular}{|c|c|}
\hline Austenita & Matriz Ferrítica \\
\hline $0,407 \pm 0,007 \%$ & $0,593 \pm 0,007 \%$ \\
\hline
\end{tabular}

O mesmo procedimento de captura, processamento digital de imagens e quantificação de fases foi realizado para todas as ZTAs simuladas em todas as 
condições estudadas no aço inoxidável lean duplex UNS S32304. As contagens de fases de austenita e ferrita no primeiro grupo de amostras (4 aportes de calor e têmpera em água a $500^{\circ} \mathrm{C}$ ) estão apresentados na Tabela 5-6 e as respectivas curvas de Fração Volumétrica vs Aporte de Calor na Figura 5-15. Os mesmos resultados do segundo grupo de amostras ( 5 aportes de calor e têmpera a $250^{\circ} \mathrm{C}$ ) estão apresentados na Tabela 5-7 e as curvas na Figura 5-16.

Tabela 5-6. Fração Volumétrica das fases calculadas pelo método de análise digital de imagem nas ZTA simuladas com 4 aportes de calor e temperadas a $500^{\circ} \mathrm{C}$ no aço inoxidável lean duplex UNS S32304 na condição como-recebido. Superfície atacada com solução Beraha Modificada. Erro calculado com $97,5 \%$ de IC.

\begin{tabular}{|c|c|c|}
\hline Aporte de Calor & Austenita & Matriz Ferrítica \\
\hline $1,5 \mathrm{~kJ} / \mathrm{mm}$ & $0,183 \pm 0,010$ & $0,817 \pm 0,010$ \\
\hline $2,0 \mathrm{~kJ} / \mathrm{mm}$ & $0,210 \pm 0,010$ & $0,790 \pm 0,010$ \\
\hline $2,5 \mathrm{~kJ} / \mathrm{mm}$ & $0,215 \pm 0,009$ & $0,785 \pm 0,009$ \\
\hline $3,0 \mathrm{~kJ} / \mathrm{mm}$ & $0,220 \pm 0,010$ & $0,780 \pm 0,010$ \\
\hline
\end{tabular}

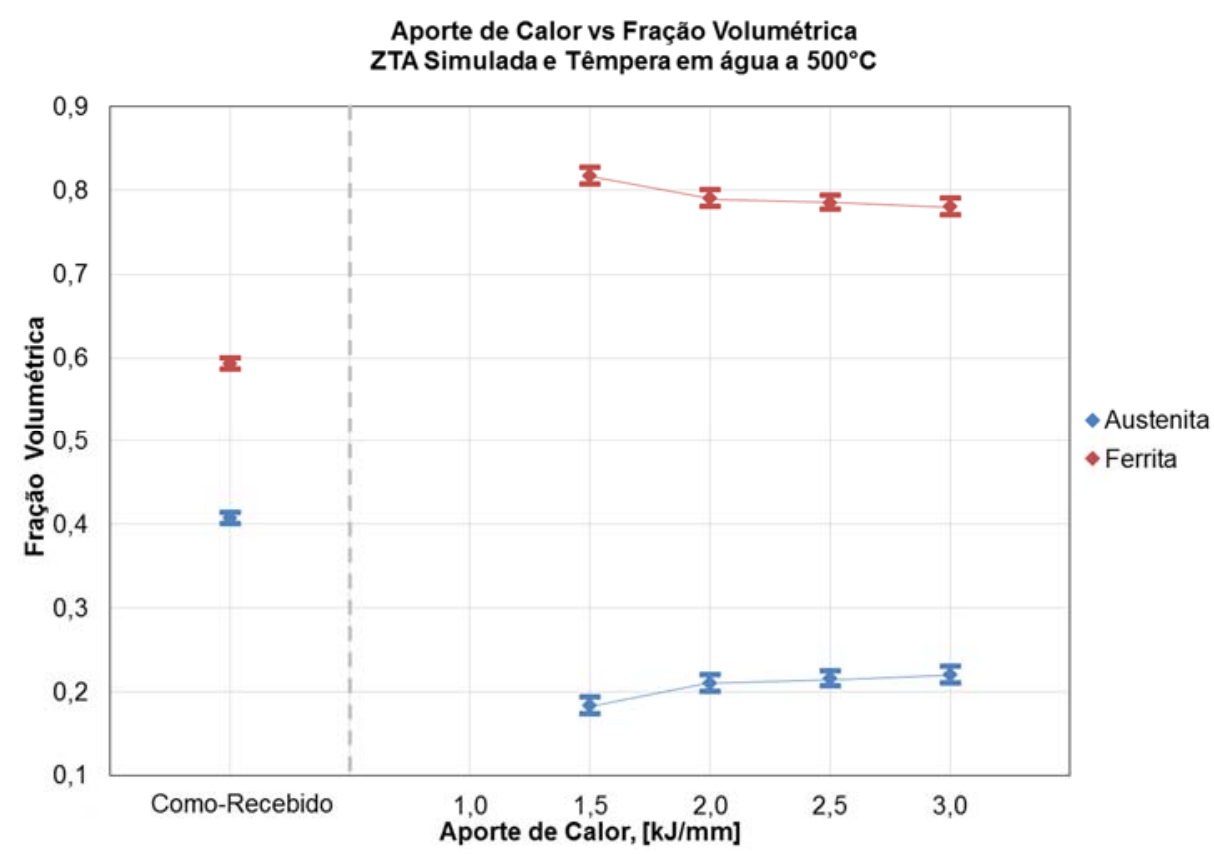

Figura 5-15. Evolução da fração volumétrica da austenita e ferrita vs o aporte de calor fornecido durante a simulação da ZTA e com têmpera em água a $500^{\circ} \mathrm{C}$ no aço inoxidável lean duplex UNS S32304, superfície atacada com solução Beraha modificada. 
Tabela 5-7. Fração volumétrica das fases calculadas pelo método de análise digital de imagem do aço inoxidável lean duplex UNS S32304 com 5 aportes de calor e temperados a $250^{\circ} \mathrm{C}$. Erro calculado com $97,5 \%$ de IC.

\begin{tabular}{|c|c|c|}
\hline Aporte de Calor & Austenita & Matriz Ferrítica \\
\hline $1,0 \mathrm{~kJ} / \mathrm{mm}$ & $0,184 \pm 0,007$ & $0,816 \pm 0,007$ \\
\hline $1,5 \mathrm{~kJ} / \mathrm{mm}$ & $0,189 \pm 0,011$ & $0,811 \pm 0,011$ \\
\hline $2,0 \mathrm{~kJ} / \mathrm{mm}$ & $0,216 \pm 0,009$ & $0,784 \pm 0,009$ \\
\hline $2,5 \mathrm{~kJ} / \mathrm{mm}$ & $0,235 \pm 0,007$ & $0,765 \pm 0,007$ \\
\hline $3,0 \mathrm{~kJ} / \mathrm{mm}$ & $0,244 \pm 0,014$ & $0,756 \pm 0,014$ \\
\hline
\end{tabular}

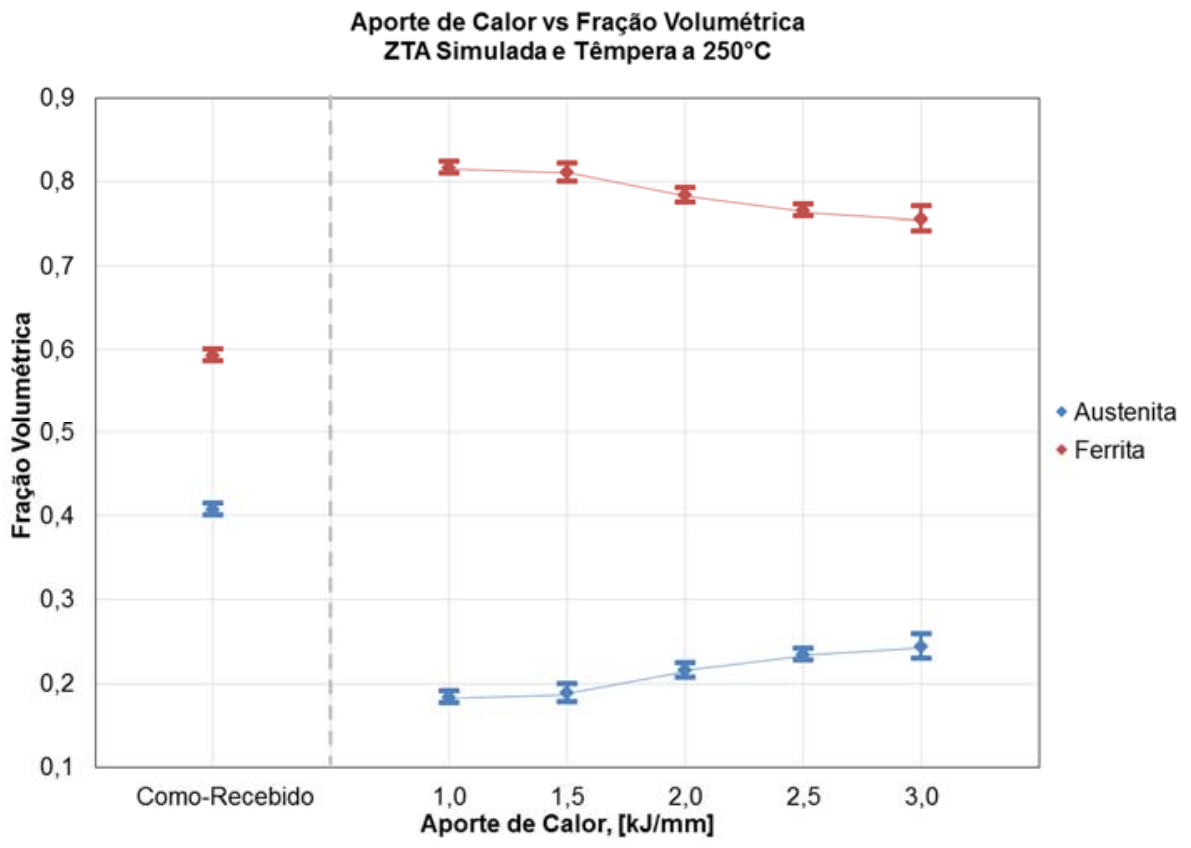

Figura 5-16. Evolução da fração folumétrica da austenita e ferrita vs o aporte de calor fornecido durante a simulação da ZTA e com têmpera a $250^{\circ} \mathrm{C}$ no aço inoxidável lean duplex UNS S32304, superfície atacada com solução Beraha modificada.

\subsubsection{2.}

\section{Aço Inoxidável Duplex UNS S32205 (2205)}

O procedimento de captura de imagens, processamento digital de imagens e quantificação das fases foi realizado nas amostras na condição de comorecebido e nas ZTAs simuladas no aço inoxidável duplex 2205. Os dados dos resultados obtidos da contagem de fases de austenita e ferrita na amostra do aço na condição de como-recebido são apresentados na Tabela 5-8.

Os resultados da contagem de fases no primeiro grupo de amostras das ZTAs simuladas (4 aportes de calor e têmpera em água a $500^{\circ} \mathrm{C}$ ) são apresentados na Tabela 5-9 e as respectivas curvas de Fração Volumétrica vs 
Aporte de Calor na Figura 5-17. Os resultados da contagens de fase do segundo grupo de amostras das ZTAs simuladas ( 5 aportes de calor e têmpera a $250^{\circ} \mathrm{C}$ ) são apresentados na Tabela 5-10 e as curvas na Figura 5-17.

Tabela 5-8. Fração volumétrica das fases calculadas pelo método de análise digital de imagem no aço inoxidável duplex UNS S32205 na condição de como-recebido, superfície atacada com solução Beraha modificada. Erro calculado com $97,5 \%$ de IC.

\begin{tabular}{|c|c|}
\hline Austenita & Matriz Ferrítica \\
\hline $0,475 \pm 0,014 \%$ & $0,525 \pm 0,014 \%$ \\
\hline
\end{tabular}

Tabela 5-9. Fração volumétrica das fases calculadas pelo método de análise digital de imagem nas ZTA simuladas com 4 aportes de calor e temperadas a $500^{\circ} \mathrm{C}$ do aço inoxidável duplex UNS S32205, superfície atacada com solução Beraha modificada. Erro calculado com $97,5 \%$ de IC.

\begin{tabular}{|c|c|c|}
\hline Aporte de Calor & Austenita & Matriz Ferrítica \\
\hline $1,5 \mathrm{~kJ} / \mathrm{mm}$ & $0,281 \pm 0,007$ & $0,719 \pm 0,007$ \\
\hline $2,0 \mathrm{~kJ} / \mathrm{mm}$ & $0,320 \pm 0,006$ & $0,679 \pm 0,006$ \\
\hline $2,5 \mathrm{~kJ} / \mathrm{mm}$ & $0,339 \pm 0,007$ & $0,661 \pm 0,007$ \\
\hline $3,0 \mathrm{~kJ} / \mathrm{mm}$ & $0,341 \pm 0,009$ & $0,659 \pm 0,009$ \\
\hline
\end{tabular}

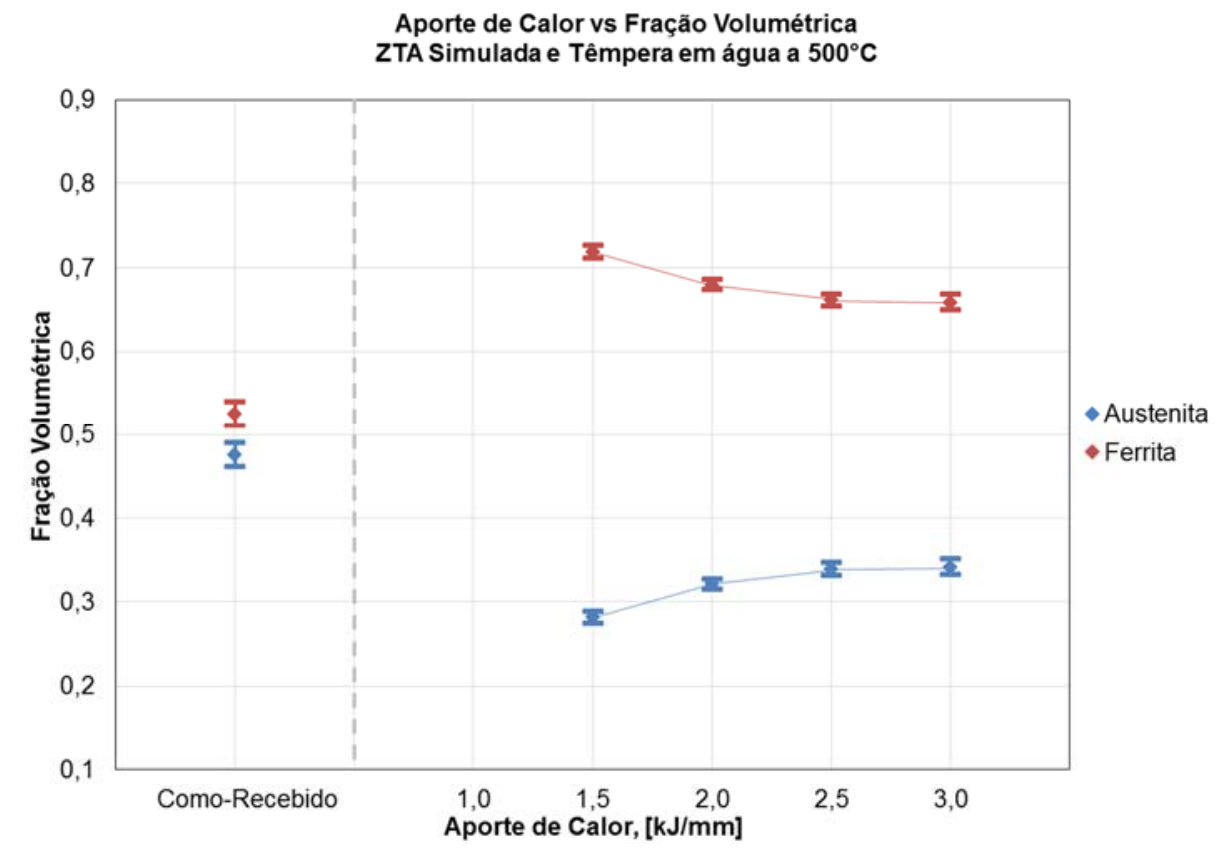

Figura 5-17. Evolução da fração volumétrica da austenita e ferrita vs o aporte de calor fornecido durante a simulação da ZTA e com têmpera em água a $500^{\circ} \mathrm{C}$ no aço inoxidável duplex UNS S32205, superfície atacada com solução Beraha modificada. 
Tabela 5-10. Fração volumétrica das fases calculadas pelo método de análise digital de imagem nas ZTA simuladas com 5 aportes de calor e temperadas a $250^{\circ} \mathrm{C}$ do aço inoxidável duplex UNS S32205, superfície atacada com solução Beraha modificada. Erro calculado com $97,5 \%$ de IC.

\begin{tabular}{|c|c|c|}
\hline Aporte de Calor & Austenita & Matriz Ferrítica \\
\hline $1,0 \mathrm{~kJ} / \mathrm{mm}$ & $0,255 \pm 0,006$ & $0,745 \pm 0,006$ \\
\hline $1,5 \mathrm{~kJ} / \mathrm{mm}$ & $0,267 \pm 0,008$ & $0,733 \pm 0,008$ \\
\hline $2,0 \mathrm{~kJ} / \mathrm{mm}$ & $0,318 \pm 0,009$ & $0,68,3 \pm 0,009$ \\
\hline $2,5 \mathrm{~kJ} / \mathrm{mm}$ & $0,349 \pm 0,009$ & $0,651 \pm 0,009$ \\
\hline $3,0 \mathrm{~kJ} / \mathrm{mm}$ & $0,351 \pm 0,013$ & $0,649 \pm 0,013$ \\
\hline
\end{tabular}

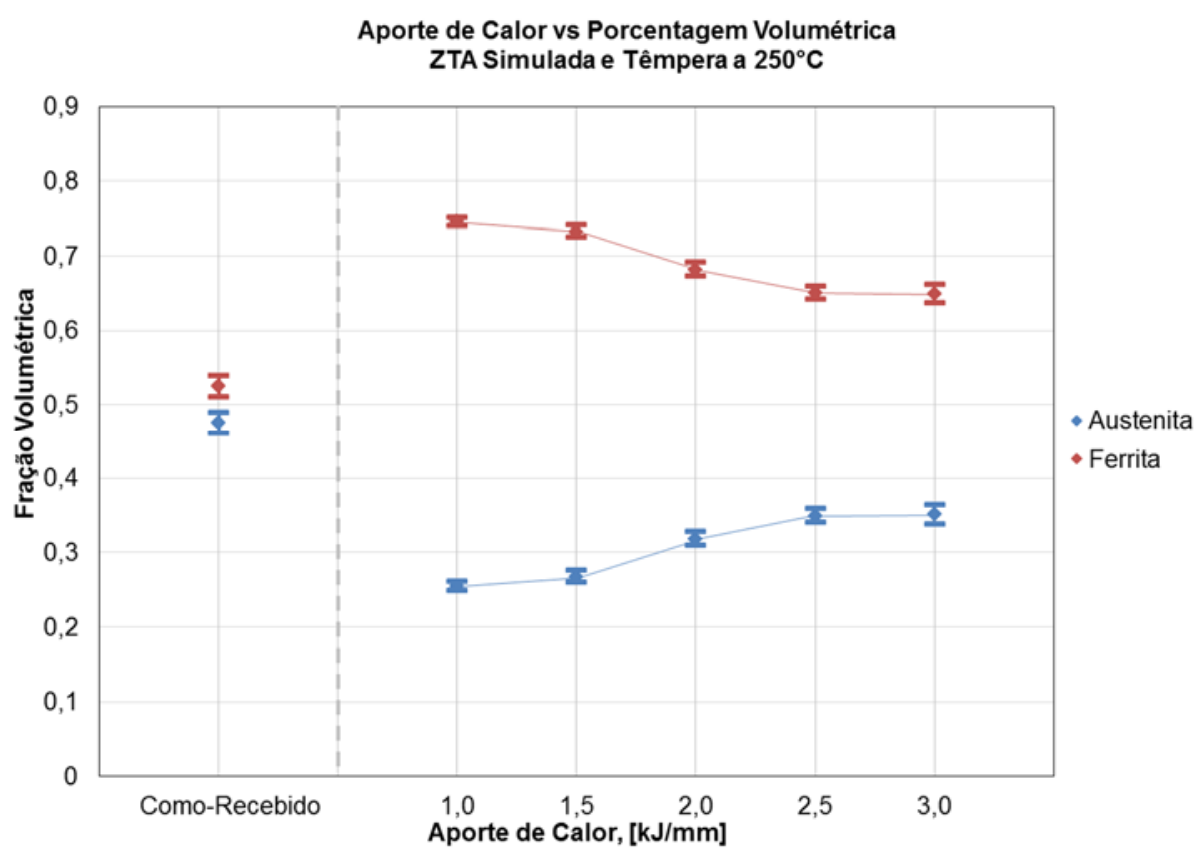

Figura 5-18. Evolução da fração volumétrica da austenita e ferrita vs o aporte de calor fornecido durante a simulação da ZTA e com têmpera a $250^{\circ} \mathrm{C}$ no aço inoxidável duplex UNS S32205, superfície atacada com solução Beraha modificada.

\subsubsection{3.}

\section{Aço Inoxidável Super Duplex UNS S32750 (2507)}

O procedimento de captura de imagens, processamento digital de imagens e quantificação das fases foi realizado nas amostras na condição de comorecebido e nas ZTAs simuladas no aço inoxidável super duplex 2507. Os dados dos resultados obtidos da contagem de fases de austenita e ferrita na amostra do aço na condição de como-recebido são apresentados na Tabela 5-11.

A Tabela 5-11 apresenta os resultados da contagem de fases no primeiro grupo de amostras das ZTAs simuladas (4 aportes de calor e têmpera em água a $500^{\circ} \mathrm{C}$ ) e as respectivas curvas Fração Volumétrica vs Aporte de Calor na Figura 
5-19. Os resultados da contagem de fase do segundo grupo de amostras das ZTAs simuladas ( 5 aportes de calor e têmpera a $250^{\circ} \mathrm{C}$ ) são apresentados na Tabela 5-13 e as curvas na Figura 5-20.

Tabela 5-11. Fração volumétrica das fases calculadas pelo método de análise digital de imagem no aço inoxidável super duplex UNS S32750 na condição de como-recebido, superfície atacada com solução Beraha modificada. Erro calculado com $97,5 \%$ de IC.

\begin{tabular}{|c|c|}
\hline Austenita & Matriz Ferrítica \\
\hline $0,492 \pm 0,011$ & $0,508 \pm 0,011$ \\
\hline
\end{tabular}

Tabela 5-12. Fração volumétrica das fases calculadas pelo método de análise digital de imagem nas ZTA simuladas com 4 aportes de calor e temperadas em água a $500^{\circ} \mathrm{C}$ do aço inoxidável super duplex UNS S32750, superfície atacada com solução Beraha modificada. Erro calculado com $97,5 \%$ de IC.

\begin{tabular}{|c|c|c|}
\hline Aporte de Calor & Austenita & Matriz Ferrítica \\
\hline $1,5 \mathrm{~kJ} / \mathrm{mm}$ & $0,460 \pm 0,011$ & $0,540 \pm 0,011$ \\
\hline $2,0 \mathrm{~kJ} / \mathrm{mm}$ & $0,439 \pm 0,007$ & $0,561 \pm 0,007$ \\
\hline $2,5 \mathrm{~kJ} / \mathrm{mm}$ & $0,538 \pm 0,010$ & $0,462 \pm 0,010$ \\
\hline $3,0 \mathrm{~kJ} / \mathrm{mm}$ & $0,559 \pm 0,012$ & $0,441 \pm 0,012$ \\
\hline
\end{tabular}

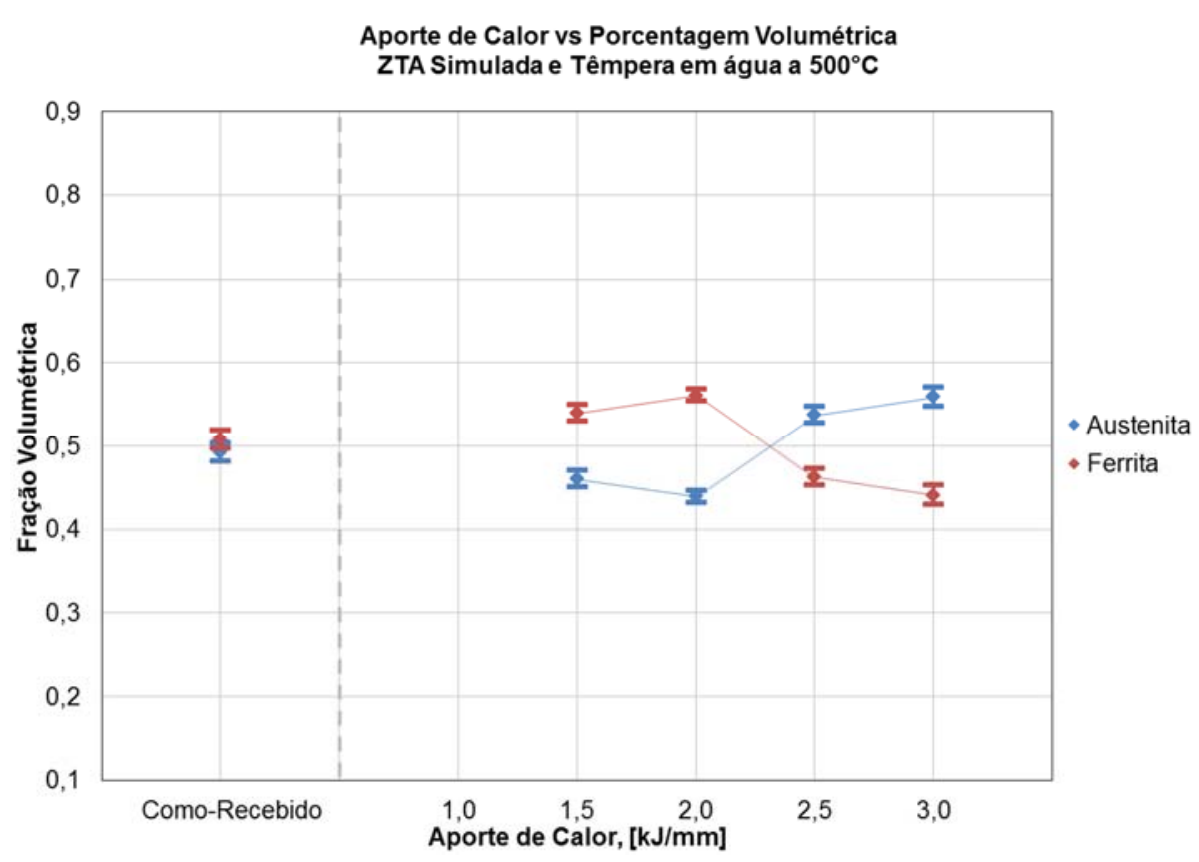

Figura 5-19. Evolução da fração volumétrica da austenita e ferrita vs o aporte de calor fornecido durante a simulação da ZTA e com têmpera em água a $500^{\circ} \mathrm{C}$ no aço inoxidável super duplex UNS S32750, superfície atacada com solução Beraha modificada. 
Tabela 5-13. Fração volumétrica das fases calculadas pelo método de análise digital de imagem nas ZTA simuladas com 5 aportes de calor e temperadas a $250^{\circ} \mathrm{C}$ do aço inoxidável super duplex UNS S32750, superfície atacada com solução Beraha modificada. Erro calculado com $97,5 \%$ de IC.

\begin{tabular}{|c|c|c|}
\hline Aporte de Calor & Austenita & Matriz Ferrítica \\
\hline $1,0 \mathrm{~kJ} / \mathrm{mm}$ & $0,444 \pm 0,011$ & $0,556 \pm 0,011$ \\
\hline $1,5 \mathrm{~kJ} / \mathrm{mm}$ & $0,491 \pm 0,042$ & $0,509 \pm 0,042$ \\
\hline $2,0 \mathrm{~kJ} / \mathrm{mm}$ & $0,487 \pm 0,012$ & $0,513 \pm 0,012$ \\
\hline $2,5 \mathrm{~kJ} / \mathrm{mm}$ & $0,509 \pm 0,021$ & $0,491 \pm 0,021$ \\
\hline $3,0 \mathrm{~kJ} / \mathrm{mm}$ & $0,438 \pm 0,010$ & $0,562 \pm 0,010$ \\
\hline
\end{tabular}

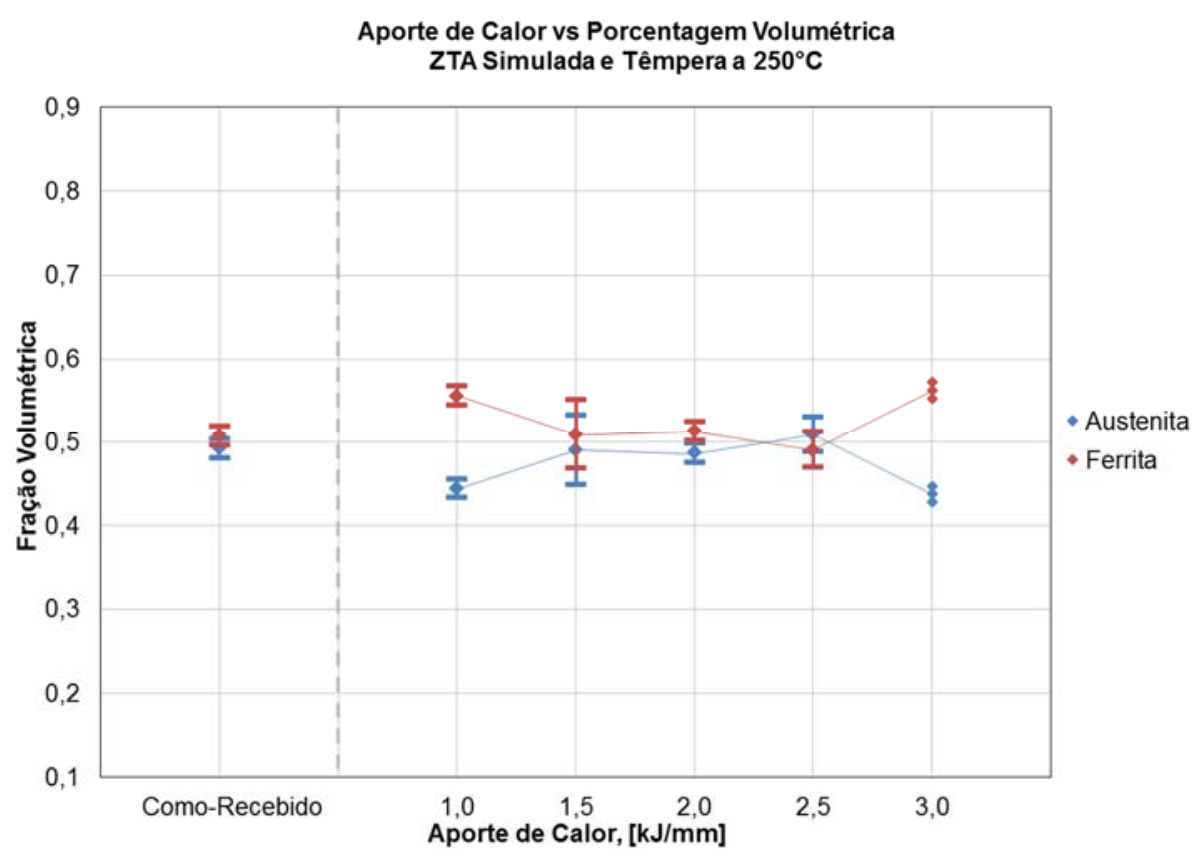

Figura 5-20. Evolução da fração volumétrica da austenita e ferrita vs o aporte de calor fornecido durante a simulação da ZTA e com têmpera a $250^{\circ} \mathrm{C}$ no aço inoxidável super duplex UNS S32750, superfície atacada com solução Beraha modificada.

\subsection{3.}

\section{Tamanho de Grão}

Observando as micrografias de todas as condições de simulação das ZTAs com aportes de calor desde $1,5 \mathrm{~kJ} / \mathrm{cm}$ (temperadas a 500 e $250^{\circ} \mathrm{C}$ ) até aportes de calor $3,0 \mathrm{~kJ} / \mathrm{mm}$ (temperadas a 500 e $250^{\circ} \mathrm{C}$ ) se pode determinar que à medida em que ocorre o incremento do aporte de calor o tamanho de grão tende a aumentar tanto da austenita quanto da ferrita nos três aços em estudo como se evidencia na evolução microestrutural nas Figuras 5-10, 5-11 e 5-12.

As amostras temperadas a $250^{\circ} \mathrm{C}$ durante a simulação da ZTA no aço lean duplex foram as que apresentaram o maior incremento no tamanho do grão da 
ferrita, o diâmetro dos grãos aumentou mais de 2,7 vezes quando o aporte de calor é incrementado desde 1,0 até 3,0 kJ/mm (o diâmetro aumentou de $275 \mu \mathrm{m}$ para $740 \mu \mathrm{m}$ ) como mostrado na Tabela 5-14, o que a corresponde a uma mudança de tamanho de grão No $G=1.0$ para um tamanho de grão macro No. M11.0 segundo a norma ASTM E112 ${ }^{101}$. A Figura 5-21 representa esquematicamente essos aumentos no tamanho de grão da ferrita nas ZTAs simuladas no aço inoxidável lean duplex.

A Tabela 5-14 apresenta o valores de incremento no tamanho de grão da ferrita para os três aços estudados quando o aporte de calor é incremento nas simulações das ZTAs.

As Figuras 5-21, 5-22 e 5-23 representam graficamente estes resultados do incremento de tamanho de grão da ferrita

Tabela 5-14. Aumento do tamanho de grão da ferrita pelo aumento de aporte de calor durante a simulação da ZTA.

\begin{tabular}{|c|c|c|}
\hline \multicolumn{3}{|c|}{ Aço Inoxidável Lean Duplex UNS S32304 } \\
\hline Têmpera com água a $500^{\circ} \mathrm{C}$ & Desde 1,5 até $3,0 \mathrm{~kJ} / \mathrm{mm}$ & $\begin{array}{l}\text { O tamanho da ferrita aumentou } \\
1,7 \text { vezes: } \\
385 \mu \mathrm{m}-660 \mu \mathrm{m}\end{array}$ \\
\hline Têmpera a $250^{\circ} \mathrm{C}$ & Desde 1,0 até $3,0 \mathrm{~kJ} / \mathrm{mm}$ & $\begin{array}{l}\text { O tamanho da ferrita aumentou } \\
2,7 \text { vezes: } \\
275 \mu \mathrm{m}-740 \mu \mathrm{m}\end{array}$ \\
\hline \multicolumn{3}{|c|}{ Aço Inoxidável Duplex UNS S32205 } \\
\hline Têmpera com água a $500^{\circ} \mathrm{C}$ & Desde 1,5 até $3,0 \mathrm{~kJ} / \mathrm{mm}$ & $\begin{array}{l}\text { O tamanho da ferrita aumentou } \\
2,2 \text { vezes: } \\
179 \mu \mathrm{m}-391 \mu \mathrm{m}\end{array}$ \\
\hline Têmpera a $250^{\circ} \mathrm{C}$ & Desde 1,0 até $3,0 \mathrm{~kJ} / \mathrm{mm}$ & $\begin{array}{l}\text { O tamanho da ferrita aumentou } \\
2,3 \text { vezes: } \\
191 \mu \mathrm{m}-430 \mu \mathrm{m}\end{array}$ \\
\hline \multicolumn{3}{|c|}{ Aço Inoxidável Super Duplex UNS S32750 } \\
\hline Têmpera com água a $500^{\circ} \mathrm{C}$ & Desde 1,5 até $3,0 \mathrm{~kJ} / \mathrm{mm}$ & $\begin{array}{l}\text { O tamanho da ferrita aumentou } \\
1,4 \text { vezes: } \\
124 \mu \mathrm{m}-175 \mu \mathrm{m}\end{array}$ \\
\hline Têmpera a $250^{\circ} \mathrm{C}$ & Desde 1,0 até $3,0 \mathrm{~kJ} / \mathrm{mm}$ & $\begin{array}{l}\text { O tamanho da ferrita aumentou } \\
1,8 \text { vezes: } \\
91 \mu \mathrm{m}-162 \mu \mathrm{m}\end{array}$ \\
\hline
\end{tabular}




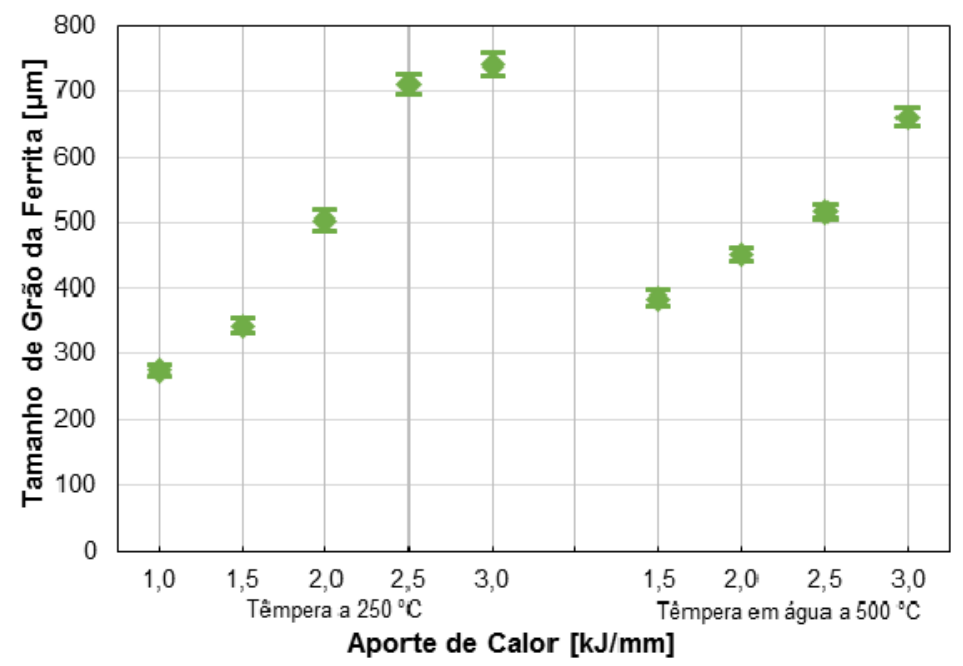

Figura 5-21. Tamanho de grão da ferrita nas ZTAs simuladas no aço lean duplex UNS S32304.

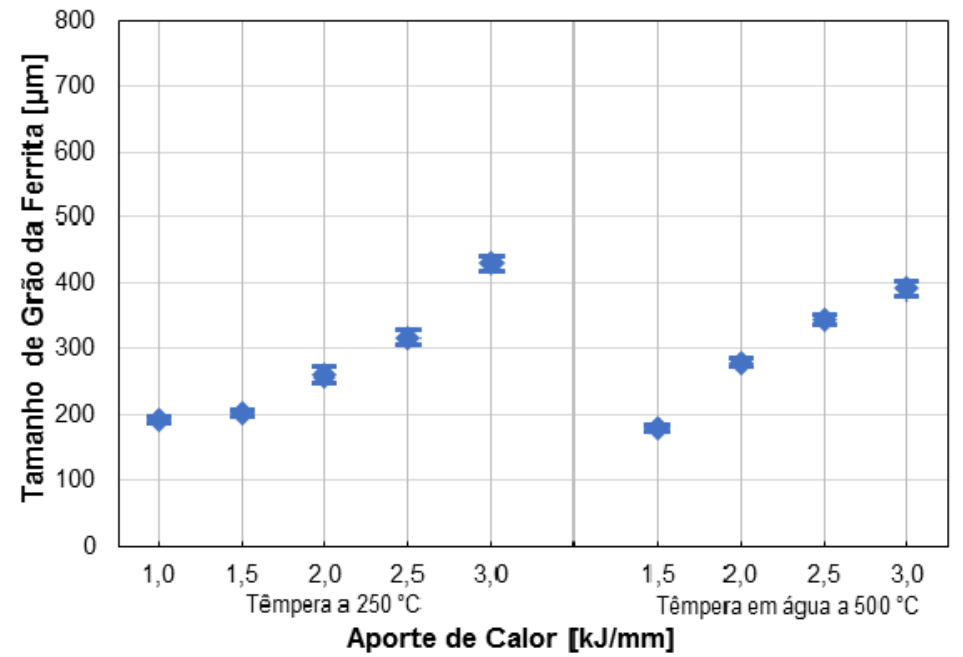

Figura 5-22. Tamanho de grão da ferrita nas ZTAs simuladas no aço duplex UNS S32205.

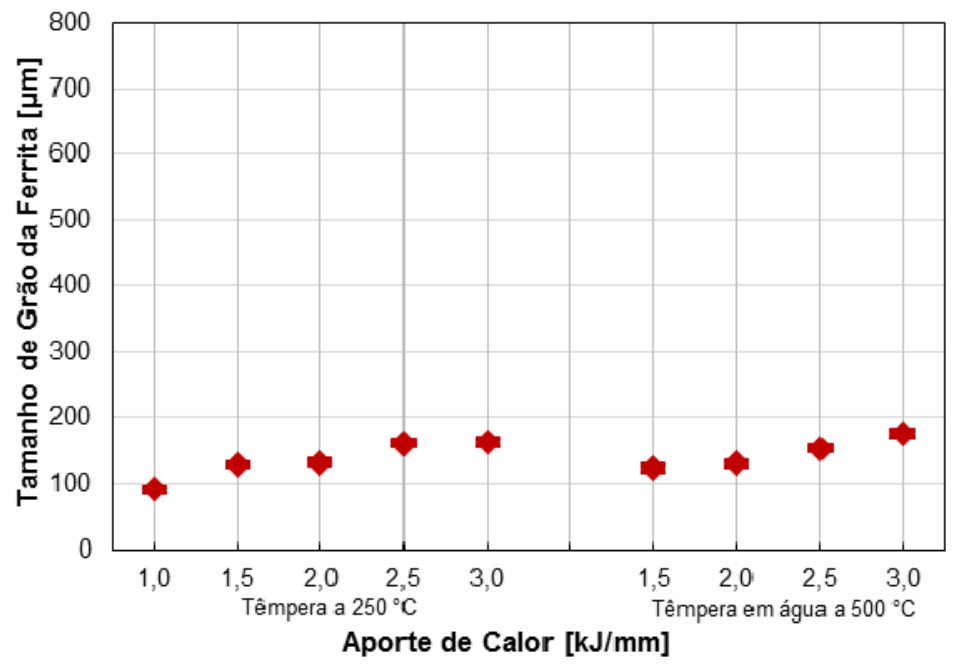

Figura 5-23. Tamanho de grão da ferrita nas ZTAs simuladas no aço super duplex UNS S32750. 
5.4.4. Identificação de Nitretos

As micrografias capturadas por microscopia ótica com DIC permitiram observar a topografia da superfície das amostras e obter melhor contraste das fases.

$\mathrm{O}$ ataque eletrolítico com solução de $40 \%$ de $\mathrm{HNO}_{3} 6591929329$ em duas etapas revelou as interfaces austenita / austenita, austenita / ferrita e ferrita / ferrita durante a primeira etapa e além deu maior contraste entre a ferrita e a austenita durante a segunda etapa do ataque. Nenhuma das amostras apresentaram evidencias de austenita secundaria, ou seja o ataque da fase austenítica foi homogéneo.

Na Figura 5-24 são apresentadas as micrografias capturadas em campo claro e com DIC do aço inoxidável lean duplex UNS S32304 das amostras na condição de como-recebido e das amostras das ZTAs simuladas com aportes de calor baixos $(1,0 \mathrm{~kJ} / \mathrm{mm})$ e altos $(3,0 \mathrm{~kJ} / \mathrm{mm})$ e com têmpera a $250^{\circ} \mathrm{C}$. Da mesma maneira, as Figuras 5-25 e 5-26 apresentam as micrografias em campo claro em com DIC do aço inoxidável duplex UNS S32205 e do aço inoxidável super duplex UNS S32750 respectivamente.

Nas micrografias capturadas com DIC dos 3 aços na condição de comorecebido se oberva que com este ataque electrolítico os cotornos de grão austenita / austenita são claramente revelados. Esse comportamento não tinha sido observado anteriormente com o ataque químico de solução Beraha, nem com o ataque electrolítico de $\mathrm{KOH}$, o que permitiu fazer as medições de tamanho de grão da austenita para os três aços em estudo na condição de como-recibido. 


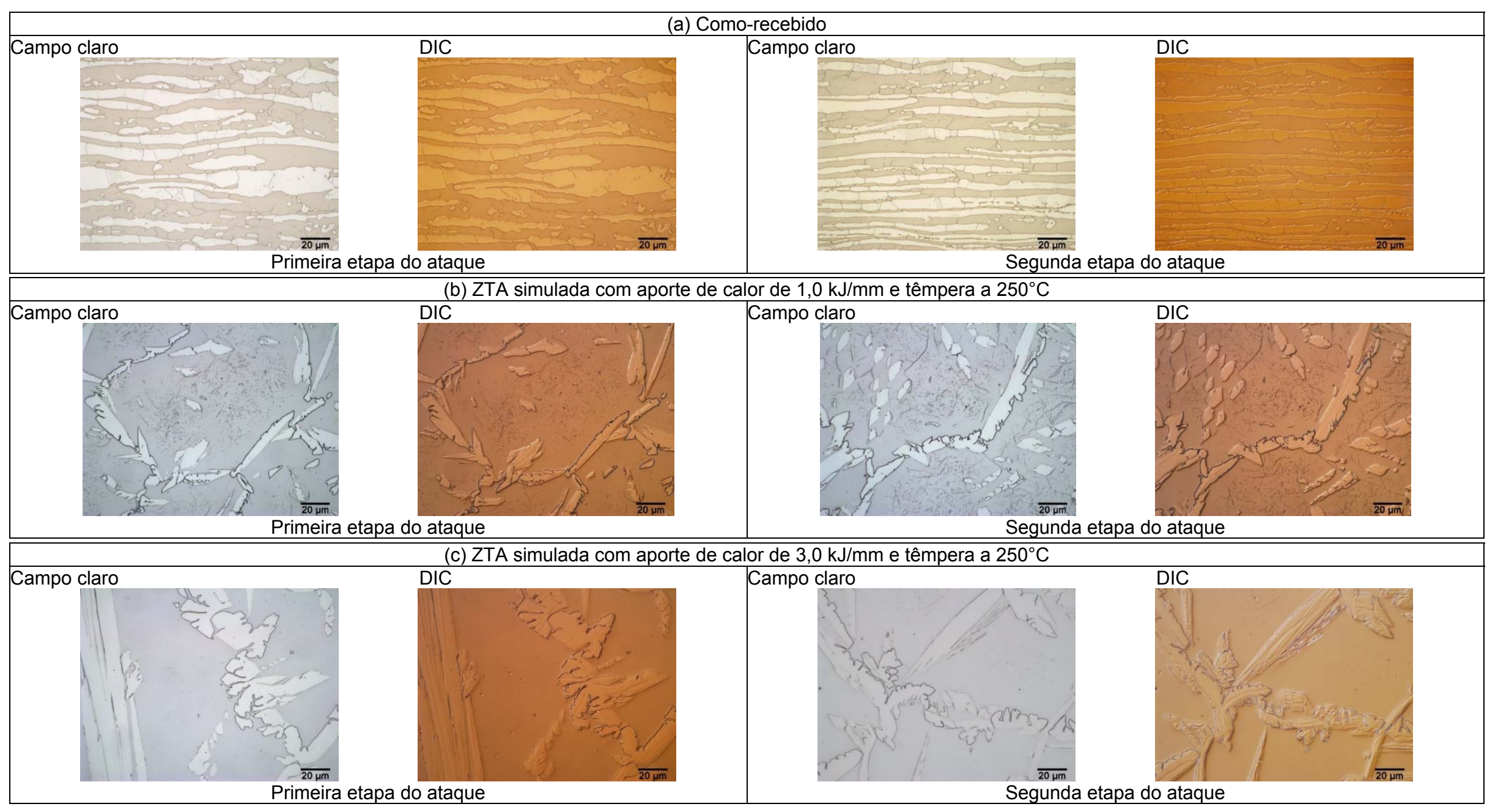

Figura 5-24. Micrografias em campo claro e DIC com aumento de 1000X do aço inoxidável lean duplex UNS S32304 com ataque eletrolítico com $\mathrm{HNO}_{3}$ em duas etapas. 


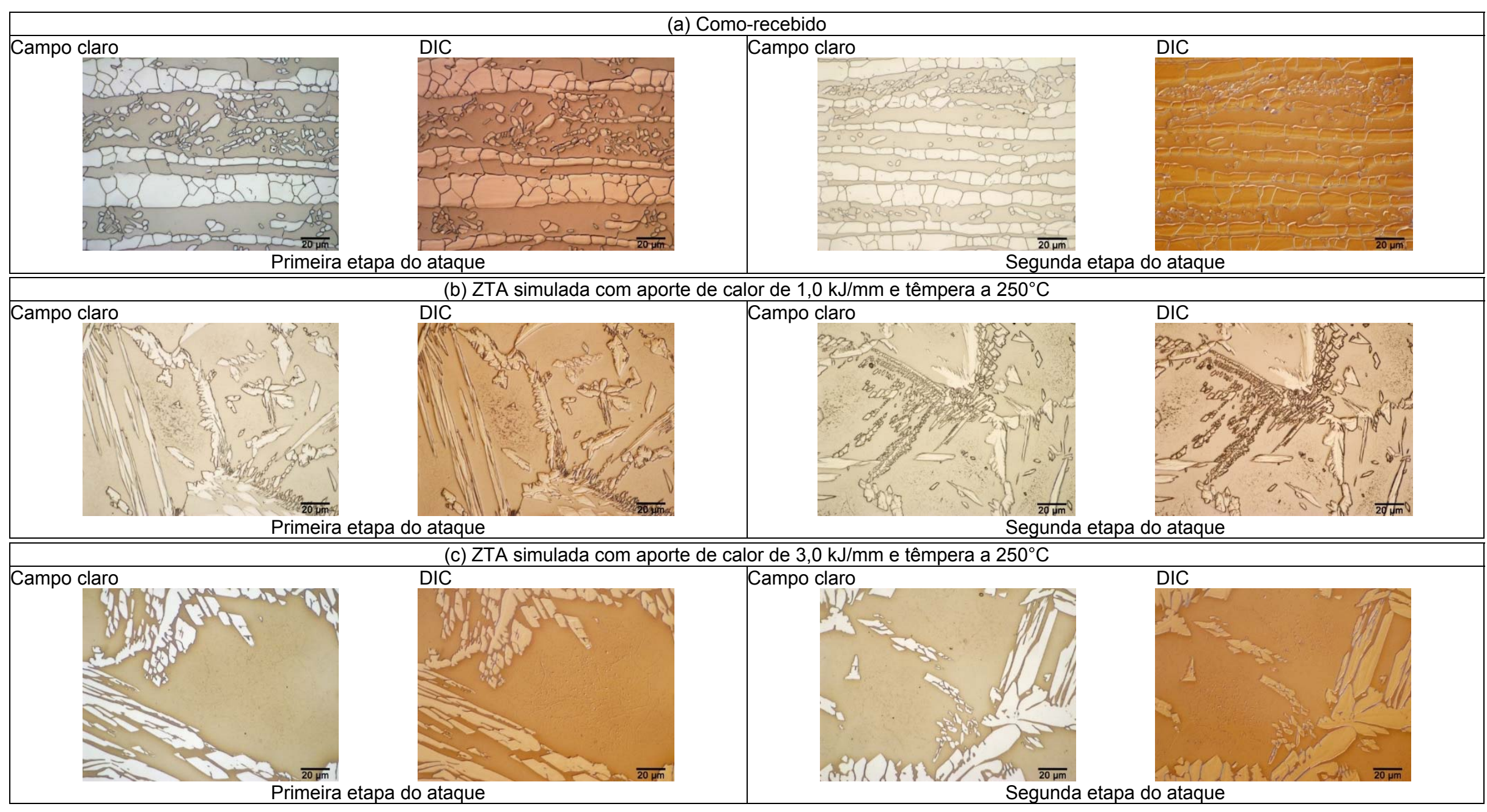

Figura 5-25. Micrografias em campo claro e DIC com aumento de 1000X do aço inoxidável duplex UNS S32205 com ataque eletrolítico com $\mathrm{HNO}_{3}$ em duas etapas. 


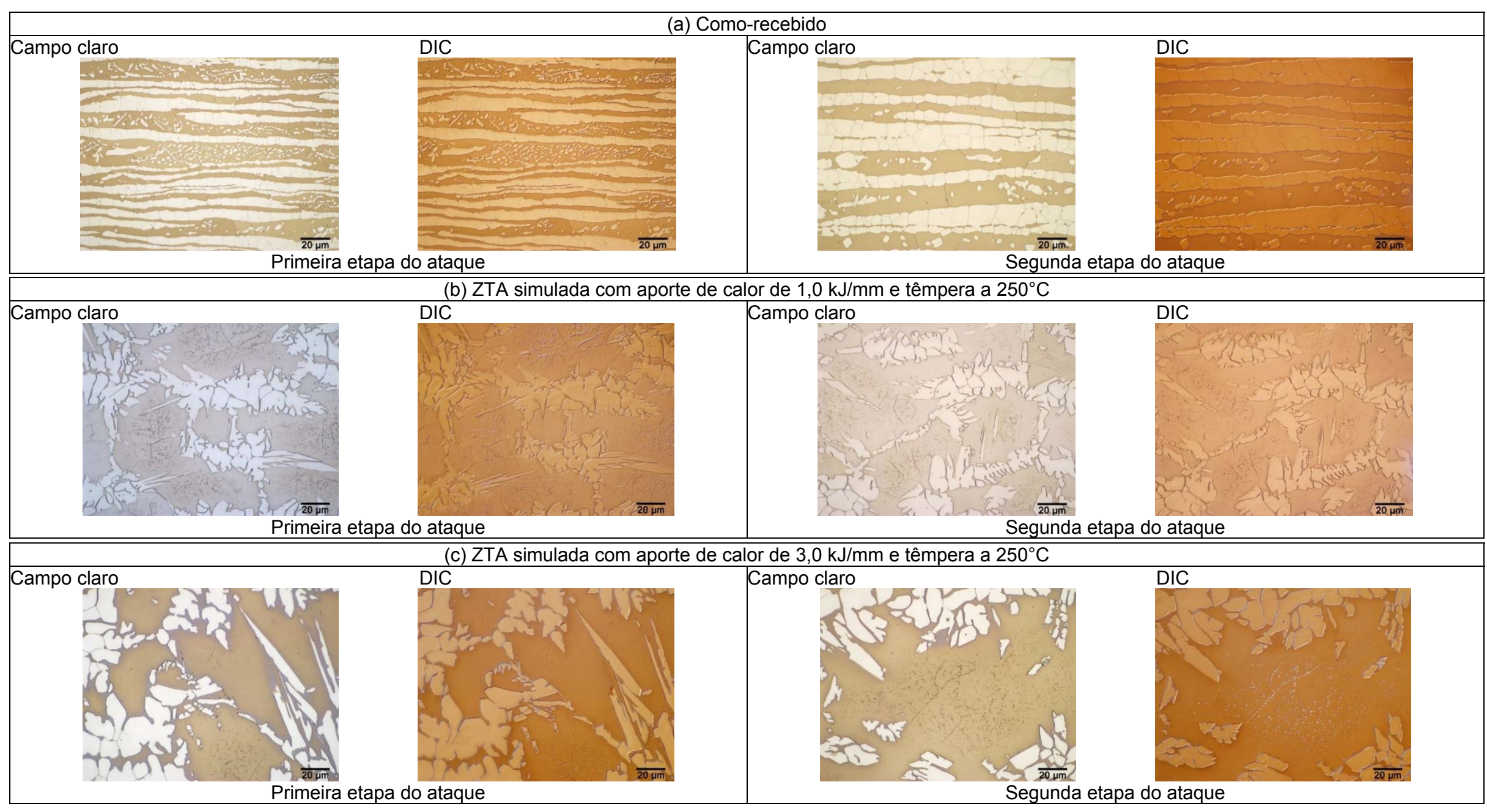

Figura 5-26. Micrografias em campo claro e DIC com aumento de 1000X do aço inoxidável super duplex UNS S32750 com ataque eletrolítico com $\mathrm{HNO}_{3}$ em duas etapas. 
Nas micrografias capturadas com DIC das amostras das ZTAs simuladas com baixo aporte de calor $(1,0 \mathrm{~kJ} / \mathrm{mm})$ e têmpera a $250^{\circ} \mathrm{C}$ dos três aços em estudo, foi identificada a presença de alguns precipitados intragranulares dentro dos grãos de ferrita que estão posívelmente associados aos precipitados de $\mathrm{Cr}_{2} \mathrm{~N} 67321$ (Tabela 5-15).

Este comportamento não foi tão evidente nas amostras com alto aporte de calor $(3,0 \mathrm{~kJ} / \mathrm{mm})$, embora existam indícios de precipitados.

Tabela 5-15. Quadro comparativo das micrografias DIC capturadas a 1000X, dos aços na condição de como-recebido e as ZTAs simuladas com aportes de calor de 1,0 e 3,0 kJ/mm.

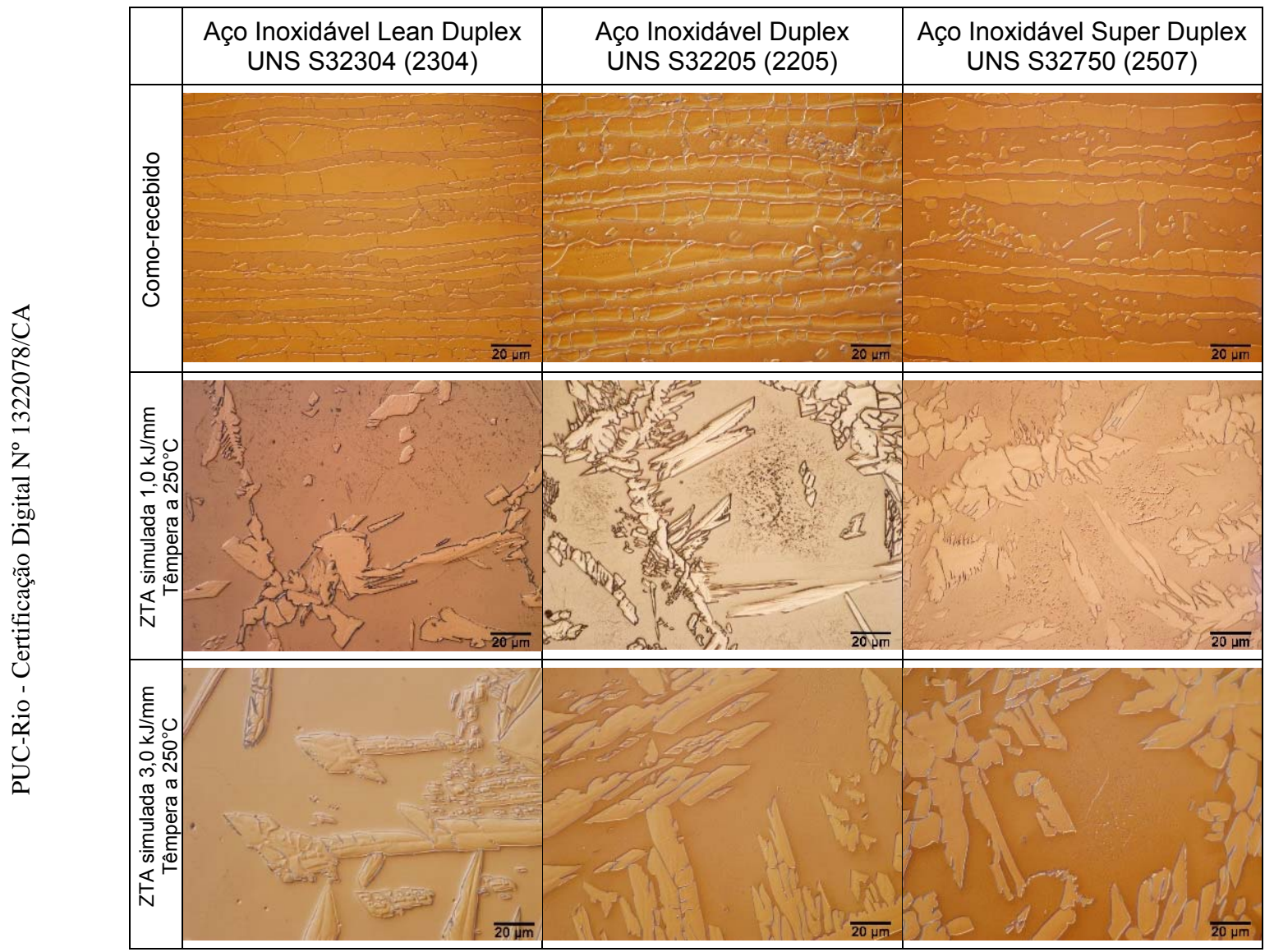

Essas mesmas amostras das ZTAs simuladas nos três aços com aporte de calor de 1,0 kJ/mm apresentam os contornos de grão ferrita / austenita com um contraste maior do que as amostras dos três aços na condição de como-recebido e das ZTAs simuladas com alto aporte de calor $(3,0 \mathrm{~kJ} / \mathrm{mm})$. Nestes contornos de grão possivelmente se encontram precipitados de $\mathrm{CrN}$ como mostrado na Figura 5-27. 


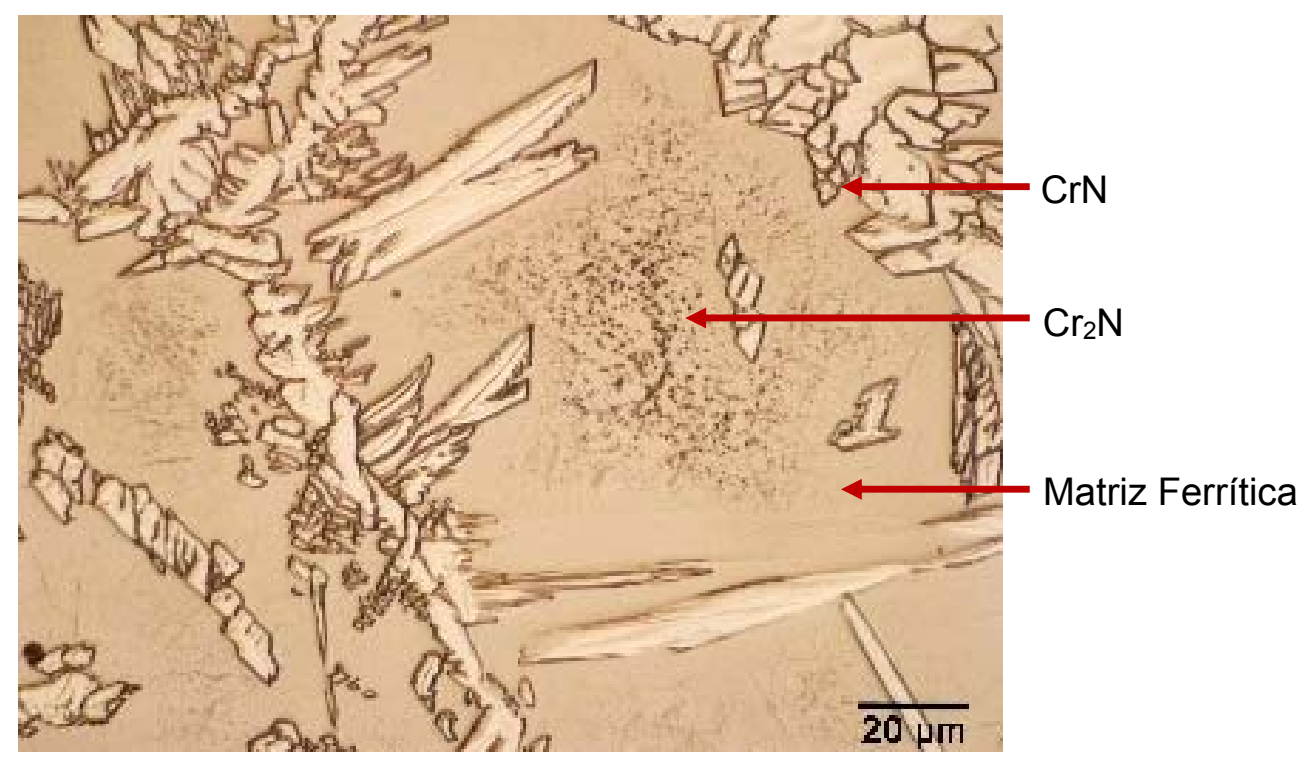

Figura 5-27. Micrografia DIC da ZTA simulada com aporte de calor de $1,0 \mathrm{~kJ} / \mathrm{mm}$ e têmpera a $250^{\circ} \mathrm{C}$ no aço duplex UNS S32205. Superfície atacada eletrolíticamente com solução de $\mathrm{HNO}_{3}$.

\section{5 .}

\section{Caraterização Mecânica}

Os resultados dos testes mecânicos de tração são mostrados mediante as curvas tensão-deformação de engenharia $\left(\begin{array}{lll}\sigma & \text { vs } & \varepsilon\end{array}\right)$. Na Figura 5-28 são apresentadas as curvas $\sigma$ vs $\varepsilon$ para os aços na condição de como-recebido testados com os dos tipos de corpos de prova, com a geometria reduzida e a geometria Gleeble. $\mathrm{Na}$ Figura 5-29 são apresentadas as curvas $\sigma$ vs $\varepsilon$ correspondentes a os testes de tração nas ZTAs simuladas nas condições de 4 aportes de calor $(1,5.2,0,2,5$ e $3,0 \mathrm{~kJ} / \mathrm{mm})$ e têmpera em água a $500^{\circ} \mathrm{C}$.

As propriedades de Módulo de elasticidade, Limite de escoamento e Limite de resistência foram medidas nos corpos de prova de geometria reduzida nos três aços na condição de como-recebido. Na Tabela 5-16 esses resultados são comparados com as propriedades mecânicas especificadas pela norma ASTM A240-15 69 e com os dados do fabricante. Nesta mesma tabela podemos comparar as propriedades de Limite de escoamento e Limite de resistência obtidas para os mesmos aços testados com os corpos de prova de geometria Gleeble na condição de como-recebido.

As propriedades mecânicas como Limite de escoamento e Limite de resistência foram medidas nos corpos de prova das ZTAs simuladas, sendo calculada a média para cada uma das condições estudadas como mostrado na Tabela 5-17. 
As Figuras 5-30 e 5-31 apresentam graficamente os resultados das propriedades mecânicas mostradas nas Tabelas 5-16 e 5-17.

Quando o teste de tração é realizado sem o uso de extensômetro como o aconteceu com as corpos de prova de geometria Gleeble, o sistema assume como medida de deslocamento o deslocamento total da ponte móvel. Assim, a deformação elástica inclui todo o conjunto mecânico do sistema de ensaios juntamente com o corpo de prova. Ou seja, existe deformação elástica das garras, sistemas de fixação, barramento, célula de carga e etc. cuja contribuição depende do nível de carregamento e da rigidez de cada máquina (compliance do sistema).

Os valores que o software da Instron (Bluehill 3) apresenta como módulo de elasticidade correspondem a uma regressão da inclinação da curva carga vs deslocamento (não é o módulo de elasticidade $(E)$ real). Por isso a caracterização mecânica por tração nos corpos de prova de geometria Gleeble só foi representada pelos cálculos de Limite de escoamento e Limite de resistência. 


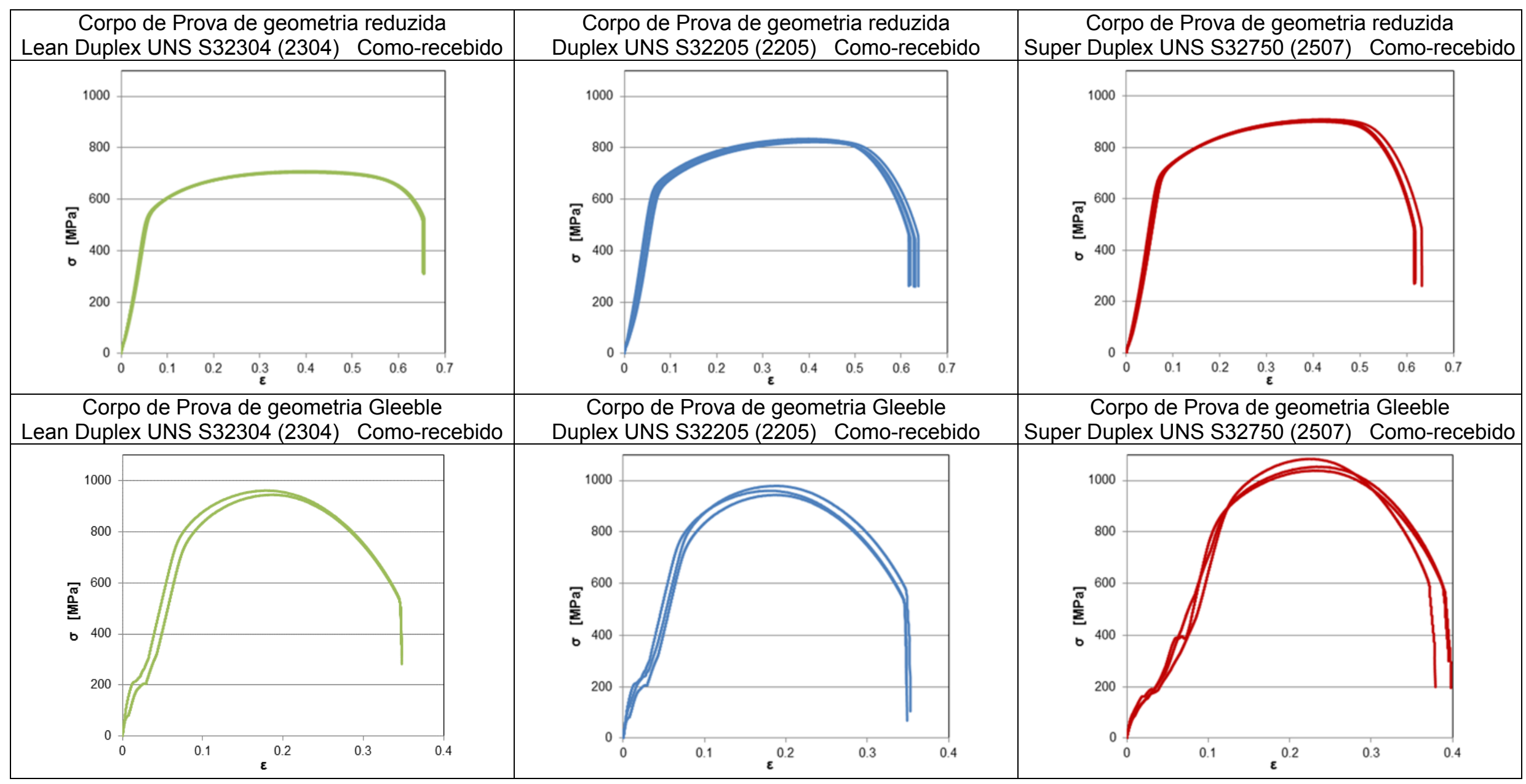

Figura 5-28. Curvas Tensão-Deformação de engenharia dos três aços em estudo na condição de como-recebido, testado nos corpos de prova de geometria: Reduzida e Gleeble. 


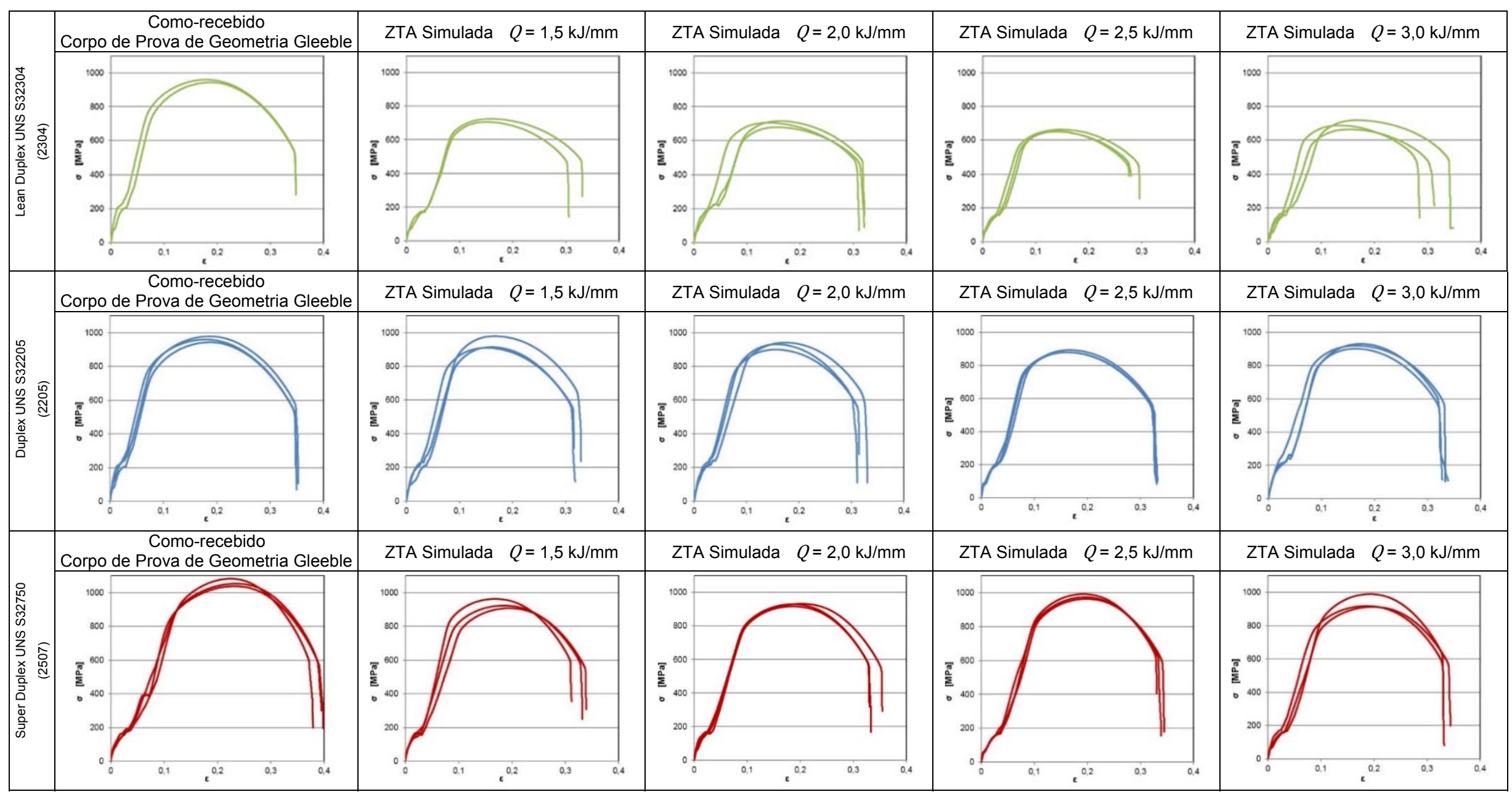

Figura 5-29. Curvas Tensão-Deformação de engenharia das ZTAs simuladas nos três aços em estudo com aportes de calor de 1,5, 2,0 2,5 e 3,0 kJ/mm. 
Tabela 5-16. Limites de escoamento, e Limites de resistência dos aços AIDs em estudo especificados pela norma ASTM A240-15 ${ }^{69}$ e o fabricante quanto os resultados obtidos na condição de como-recebido com os dois tipos de corpos de prova, de geometria Reduzida ${ }^{95}$ e geometria Gleeble.

\begin{tabular}{|c|c|c|c|c|c|c|c|c|c|}
\hline & \multicolumn{3}{|c|}{ ASTM A240-15 ${ }^{69}$} & \multicolumn{3}{|c|}{$\begin{array}{l}\text { Como-Recebido } \\
\text { Corpo de Prova de geometria Reduzida }\end{array}$} & \multicolumn{3}{|c|}{$\begin{array}{l}\text { Como-Recebido } \\
\text { Corpo de Prova de geometria Reduzida }\end{array}$} \\
\hline & $\begin{array}{l}\text { Lean Duplex } \\
\text { UNS S32304 }\end{array}$ & $\begin{array}{c}\text { Duplex } \\
\text { UNS S32205 } \\
\end{array}$ & $\begin{array}{l}\text { Super Duplex } \\
\text { UNS S32750 }\end{array}$ & \begin{tabular}{l|} 
Lean Duplex \\
UNS S32304 \\
\end{tabular} & \begin{tabular}{c|} 
Duplex \\
UNS S32205 \\
\end{tabular} & $\begin{array}{l}\text { Super Duplex } \\
\text { UNS S32750 } \\
\end{array}$ & \begin{tabular}{l|} 
Lean Duplex \\
UNS S32304 \\
\end{tabular} & \begin{tabular}{|c|} 
Duplex \\
UNS S32205 \\
\end{tabular} & $\begin{array}{l}\text { Super Duplex } \\
\text { UNS S32750 } \\
\end{array}$ \\
\hline Quantidade de Corpos de Prova & -- & -- & -- & 5 & 5 & 5 & 2 & 3 & 3 \\
\hline Velocidade de Carga, [mm/min] & -- & -- & -- & 3 & 3 & 3 & 1,5 & 1,5 & 1,5 \\
\hline $\begin{array}{l}\text { Limite de Escoamento, [MPa] } \\
\text { Média } \\
\text { Erro }\end{array}$ & $\begin{array}{r}\text { Mínima } \\
400\end{array}$ & $\begin{array}{r}\text { Mínima } \\
450\end{array}$ & $\begin{array}{r}\text { Mínima } \\
550\end{array}$ & $\begin{array}{r}561,5 \\
0,6 \\
\end{array}$ & $\begin{array}{r}653,4 \\
3,1\end{array}$ & $\begin{array}{r}716,3 \\
2,6 \\
\end{array}$ & $\begin{array}{r}826,8 \\
7,6\end{array}$ & $\begin{array}{r}837,2 \\
9,9 \\
\end{array}$ & $\begin{array}{r}928,1 \\
18,0\end{array}$ \\
\hline $\begin{array}{l}\text { Limite de Resistencia, [MPa] } \\
\text { Média } \\
\text { Erro }\end{array}$ & $\begin{array}{r}\text { Mínima } \\
600\end{array}$ & $\begin{array}{r}\text { Mínima } \\
655\end{array}$ & $\begin{array}{r}\text { Mínima } \\
795\end{array}$ & $\begin{array}{r}706,2 \\
0,7\end{array}$ & $\begin{array}{r}827,6 \\
1,9\end{array}$ & $\begin{array}{r}906,3 \\
1,3\end{array}$ & $\begin{array}{r}952,5 \\
5,6\end{array}$ & $\begin{array}{r}961,4 \\
8,2\end{array}$ & $\begin{array}{r}1058,9 \\
10,9\end{array}$ \\
\hline
\end{tabular}

Tabela 5-17. Limites de escoamento, e Limites de resistência obtidos nas ZTAs simuladas do primeiro grupo de corpos de prova nas condições de 4 aportes de calor e tempera em água a $500^{\circ} \mathrm{C}$.

\begin{tabular}{|c|c|c|c|c|c|c|c|c|c|c|c|c|}
\hline & \multicolumn{3}{|c|}{$\begin{array}{c}\text { ZTA Simulada } \\
Q=1,5 \mathrm{~kJ} / \mathrm{mm} \text { Têmpera a } 500^{\circ} \mathrm{C}\end{array}$} & \multicolumn{3}{|c|}{$\begin{array}{c}\text { ZTA Simulada } \\
Q=2,0 \mathrm{~kJ} / \mathrm{mm} \text { Têmpera a } 500^{\circ} \mathrm{C}\end{array}$} & \multicolumn{3}{|c|}{$\begin{array}{c}\text { ZTA Simulada } \\
Q=2,5 \mathrm{~kJ} / \mathrm{mm} \text { Têmpera a } 500^{\circ} \mathrm{C}\end{array}$} & \multicolumn{3}{|c|}{$\begin{array}{c}\text { ZTA Simulada } \\
Q=3,0 \mathrm{~kJ} / \mathrm{mm} \text { Têmpera a } 500^{\circ} \mathrm{C}\end{array}$} \\
\hline & $\begin{array}{l}\text { Lean Duplex } \\
\text { UNS S32304 }\end{array}$ & \begin{tabular}{|c|} 
Duplex \\
UNS S32205 \\
\end{tabular} & \begin{tabular}{|c|} 
Super \\
Duplex \\
UNS S32750 \\
\end{tabular} & $\begin{array}{l}\text { Lean Duplex } \\
\text { UNS S32304 }\end{array}$ & \begin{tabular}{|c|} 
Duplex \\
UNS S32205 \\
\end{tabular} & \begin{tabular}{|c|} 
Super \\
Duplex \\
UNS S32750 \\
\end{tabular} & \begin{tabular}{|l|} 
Lean Duplex \\
UNS S32304
\end{tabular} & \begin{tabular}{|c|} 
Duplex \\
UNS S32205 \\
\end{tabular} & \begin{tabular}{|c|} 
Super \\
Duplex \\
UNS S32750 \\
\end{tabular} & $\begin{array}{l}\text { Lean Duplex } \\
\text { UNS S32304 } \\
\end{array}$ & \begin{tabular}{|c|} 
Duplex \\
UNS S32205
\end{tabular} & $\begin{array}{c}\text { Super } \\
\text { Duplex } \\
\text { UNS S32750 }\end{array}$ \\
\hline Quantidade de Corpos de Prova & 2 & 3 & 3 & 3 & 3 & 3 & 3 & 3 & 3 & 3 & 3 & 3 \\
\hline Velocidade de Carga, [mm/min] & 1,5 & 1,5 & 1,5 & 1,5 & 1,5 & 1,5 & 1,5 & 1,5 & 1,5 & 1,5 & 1,5 & 1,5 \\
\hline $\begin{array}{l}\text { Limite de Escoamento, [MPa] } \\
\text { Média } \\
\text { Erro }\end{array}$ & $\begin{array}{r}668,5 \\
5,0\end{array}$ & $\begin{array}{r}870,9 \\
20,5\end{array}$ & $\begin{array}{r}851,7 \\
12,7\end{array}$ & $\begin{array}{r}649,3 \\
6,9\end{array}$ & $\begin{array}{r}858,3 \\
14,0\end{array}$ & $\begin{array}{r}836,1 \\
1,2\end{array}$ & $\begin{array}{r}611,8 \\
3,1\end{array}$ & $\begin{array}{r}809,4 \\
4,5\end{array}$ & $\begin{array}{r}879,0 \\
6,5\end{array}$ & $\begin{array}{r}644,1 \\
12,8\end{array}$ & $\begin{array}{r}844,7 \\
3,4\end{array}$ & $\begin{array}{r}833,7 \\
8,5 \\
\end{array}$ \\
\hline $\begin{array}{l}\text { Limite de Resistencia, [MPa] } \\
\text { Média } \\
\text { Erro } \\
\end{array}$ & $\begin{array}{r}715,4 \\
6,7 \\
\end{array}$ & $\begin{array}{r}936,0 \\
18,8 \\
\end{array}$ & $\begin{array}{r}932,1 \\
13,3 \\
\end{array}$ & $\begin{array}{r}699,5 \\
9,0 \\
\end{array}$ & $\begin{array}{r}923,8 \\
10,1 \\
\end{array}$ & $\begin{array}{r}926,8 \\
3,5 \\
\end{array}$ & $\begin{array}{r}657,4 \\
9,0 \\
\end{array}$ & $\begin{array}{r}885,0 \\
3,9 \\
\end{array}$ & $\begin{array}{r}976,5 \\
6,5 \\
\end{array}$ & $\begin{array}{r}690,3 \\
12,6 \\
\end{array}$ & $\begin{array}{r}918,6 \\
7,3 \\
\end{array}$ & $\begin{array}{r}918,8 \\
3,4 \\
\end{array}$ \\
\hline
\end{tabular}




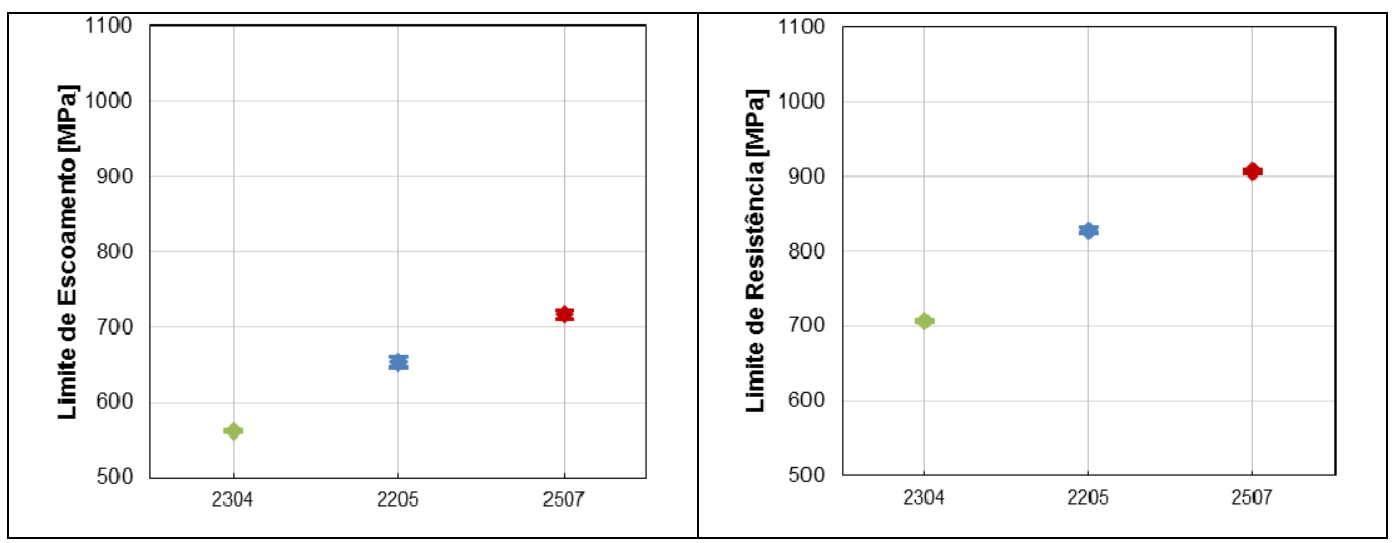

Figura 5-30. Propriedades mecânicas do aços na condição de como-recebido testados nos corpos de prova de geometria reduzida.

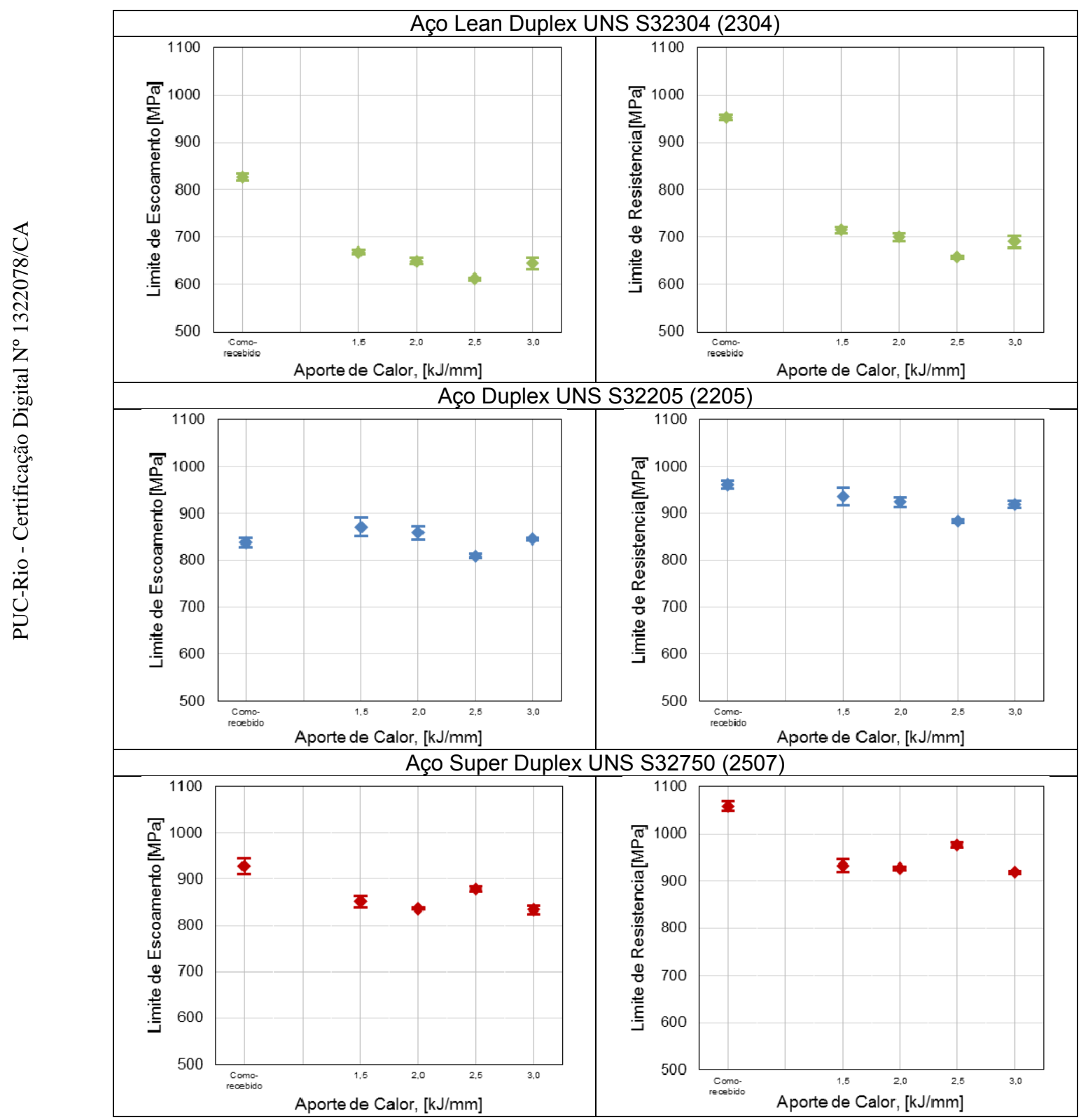

Figura 5-31. Limite de escoamento e Limite de resistência dos aços na condição de como-recebido e das ZTAs simuladas testados nos copos de prova de geometria da Gleeble. 
Quando é preciso determinar o módulo de elasticidade é obrigatório usar o extensômetro, assim os corpos de prova de geometria Gleeble os quais tem um diâmetro pequeno não permitiram o uso do extensômetro. Nesses corpos de prova não foi possível calcular o módulo de elasticidade.

Para determinar o limite de escoamento o sistema da Instron utiliza uma reta de referência para delimitar o regime elástico e denomina a inclinação desta reta como sendo o módulo, seja com ou sem o uso de extensômetro.

Só os valores de limite de escoamento, limite de resistência, alongamento e redução de área calculados pelo sistema são calculados porque estes valores não sofrem interferência do $E$ que o sistema calcula.

As imagens capturadas no MEV com detector de elétrons secundários indicam que o tipo de fratura apresentada em todos os corpos de prova é uma fratura dúctil, tanto nos três aços estudados na condição de como-recebido quanto nas ZTAs simuladas em todas as condições de simulação do primeiro grupo de corpos de prova (têmpera em água a $500^{\circ} \mathrm{C}$ ) como exemplificado na Figura 5-32.

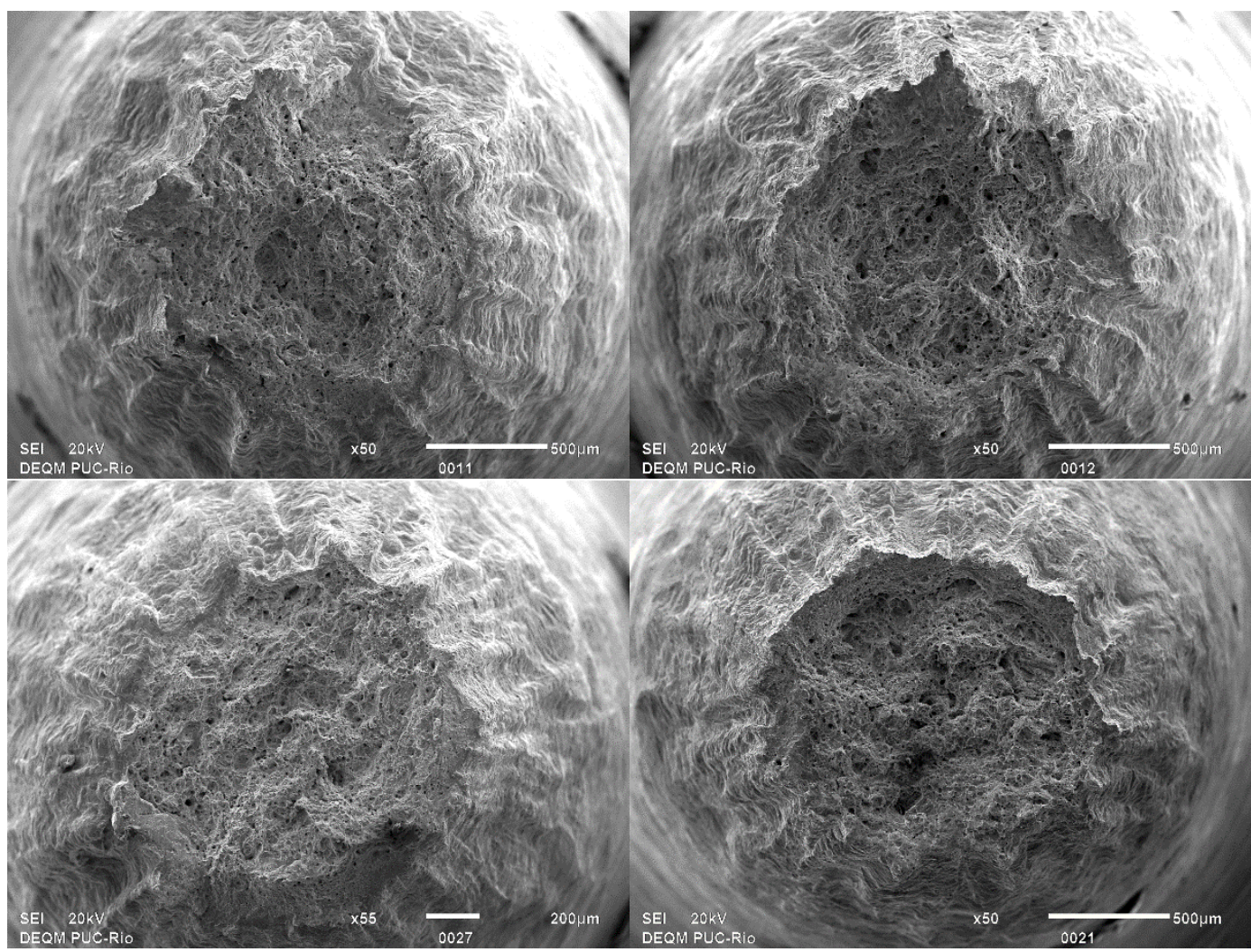

Figura 5-32. Imagens por MEV com elétrons secundários da fratura da ZTA simulada com aporte de calor de $1,5 \mathrm{~kJ} / \mathrm{mm}$ e têmpera em água a $500^{\circ} \mathrm{C}$ no aço duplex UNS $\$ 32205$. 


\section{6.}

\section{Microdureza Vickers}

Inicialmente foram realizados os testes de microdureza HV1 nas amostras dos três aços AIDs na condição de como-recebido e nas ZTAs simuladas com aportes de calor 1,0 e $3,0 \mathrm{~kJ} / \mathrm{mm}$ e com têmpera a $250^{\circ} \mathrm{C}$. A indentação com a carga de $1000 \mathrm{gf}(9.807 \mathrm{~N})$ é relativamente grande e permite avaliar a dureza nos aços e nas ZTAs simuladas incluindo o efeito de todas as fases presentes como mostrado na Tabela 5-18. A Figura 5-33 representa esses resultados.

Tabela 5-18. Microdurezas HV1 dos AIDs e das ZTAs simuladas com aportes de calor de 1,0 e 3,0 $\mathrm{kJ} / \mathrm{mm}$ com têmpera a $250^{\circ} \mathrm{C}$.

\begin{tabular}{|c|c|c|c|c|c|c|c|c|}
\hline \multicolumn{3}{|c|}{$\begin{array}{c}\text { Lean Duplex } \\
\text { UNS S32304 }\end{array}$} & \multicolumn{3}{c|}{$\begin{array}{c}\text { Duplex } \\
\text { UNS S32205 }\end{array}$} & \multicolumn{3}{c|}{$\begin{array}{c}\text { Super Duplex } \\
\text { UNS S32750 }\end{array}$} \\
\hline $\begin{array}{c}\text { Como- } \\
\text { recebido }\end{array}$ & $\begin{array}{l}Q=1,0 \\
\mathrm{~kJ} / \mathrm{mm}\end{array}$ & $\begin{array}{l}Q=3,0 \\
\mathrm{~kJ} / \mathrm{mm}\end{array}$ & $\begin{array}{c}\text { Como- } \\
\text { recebido }\end{array}$ & $\begin{array}{c}Q=1,0 \\
\mathrm{~kJ} / \mathrm{mm}\end{array}$ & $\begin{array}{l}Q=3,0 \\
\mathrm{~kJ} / \mathrm{mm}\end{array}$ & $\begin{array}{c}\text { Como- } \\
\text { recebido }\end{array}$ & $\begin{array}{l}Q=1,0 \\
\mathrm{~kJ} / \mathrm{mm}\end{array}$ & $\begin{array}{l}Q=3,0 \\
\mathrm{~kJ} / \mathrm{mm}\end{array}$ \\
\hline $232 \pm 1$ & $227 \pm 3$ & $231 \pm 1$ & $249 \pm 1$ & $269 \pm 2$ & $257 \pm 1$ & $246 \pm 3$ & $289 \pm 2$ & $288 \pm 2$ \\
\hline
\end{tabular}

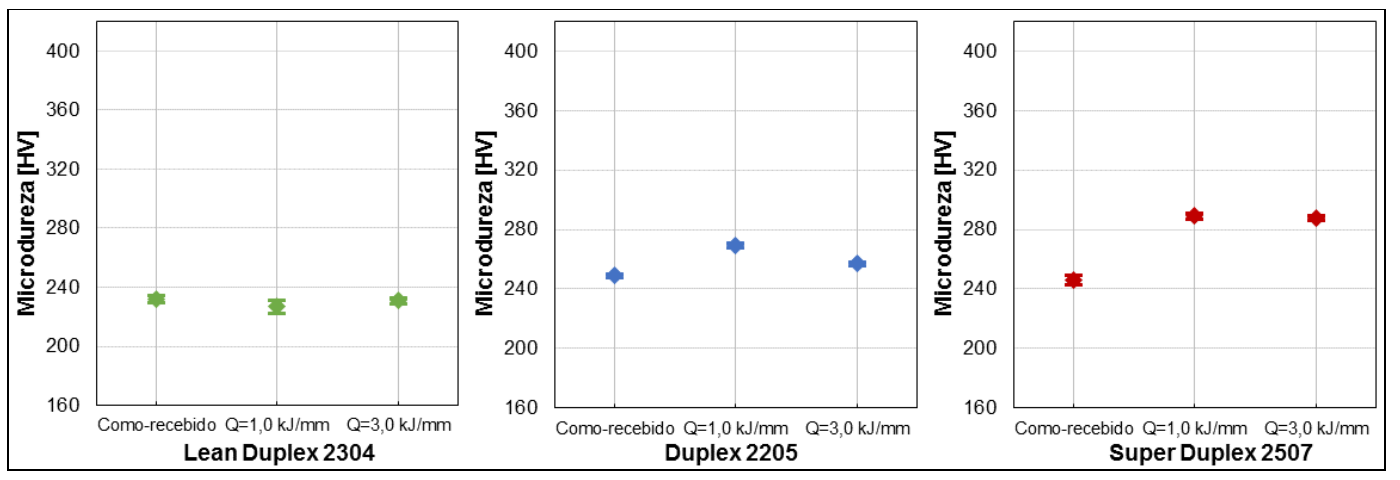

Figura 5-33. Microdureza HV1 dos AIDs e das ZTAs simuladas com aportes de calor de 1,0 e 3,0 $\mathrm{kJ} / \mathrm{mm}$ com têmpera a $250^{\circ} \mathrm{C}$.

Na Figura 5-34 são mostrados algumas micrografias com aumento de 200X que exemplificam as regiões identadas com HV1 no aço lean duplex UNS S32304 na condição de como-recebido e nas ZTAs simuladas com aportes de calor de 1,0 e $3,0 \mathrm{~kJ} / \mathrm{mm}$. 


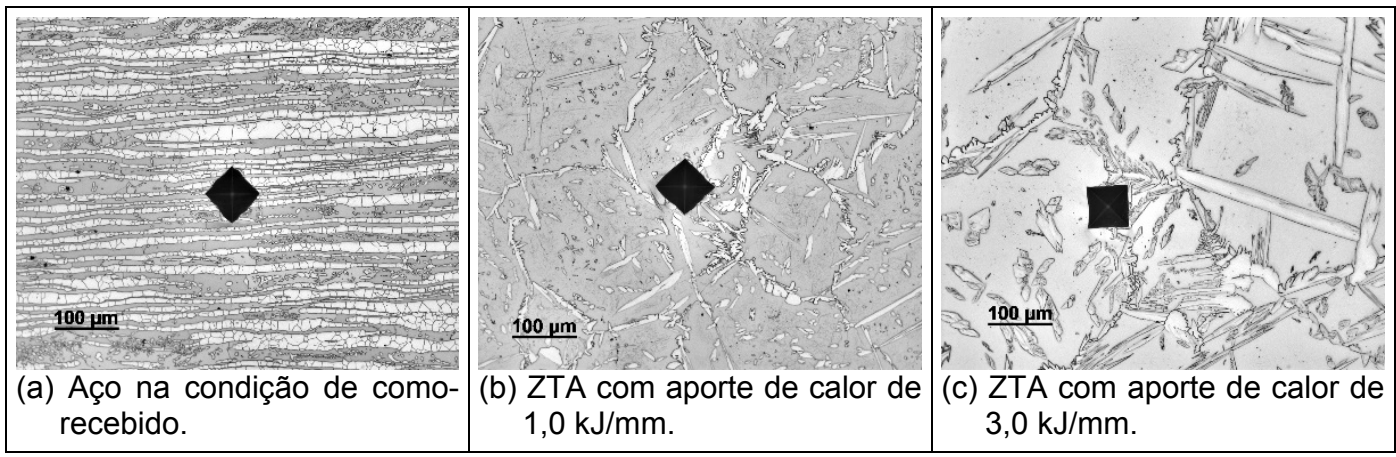

Figura 5-34. Micrografias de indentação HV01 no aço lean duplex UNS S32304.

Os testes de microdureza HV0.01 98 nas fases austenita e ferrita de morfologia lamelar foram realizadas nas amostras dos três aços estudados na condição de como-recebido.

A Tabela 5-19 mostra esses resultados, e como esperado as fases austenita e ferrita do aço super duplex foram as mais duras e as fases do aço lean duplex foram as mais macias. A Figura 5-35 representa esses resultados com barras de erro para os três aços na condição de como-recebido.

Tabela 5-19. Microdureza HV0.01 das fases austenita e ferrita nos aços em estudo na condição de como-recebido.

\begin{tabular}{|c|c|c|c|c|c|}
\hline \multicolumn{2}{|c|}{$\begin{array}{c}\text { UNS S32304 } \\
\text { Como-recebido }\end{array}$} & \multicolumn{2}{c|}{$\begin{array}{c}\text { UNS S32205 } \\
\text { Como-recebido }\end{array}$} & \multicolumn{2}{c|}{$\begin{array}{c}\text { UNS S32750 } \\
\text { Como-recebido }\end{array}$} \\
\hline Austenita & Ferrita & Austenita & Ferrita & Austenita & Ferrita \\
\hline $229 \pm 12$ & $190 \pm 8$ & $247 \pm 4$ & $226 \pm 8$ & $249 \pm 4$ & $236 \pm 7$ \\
\hline
\end{tabular}

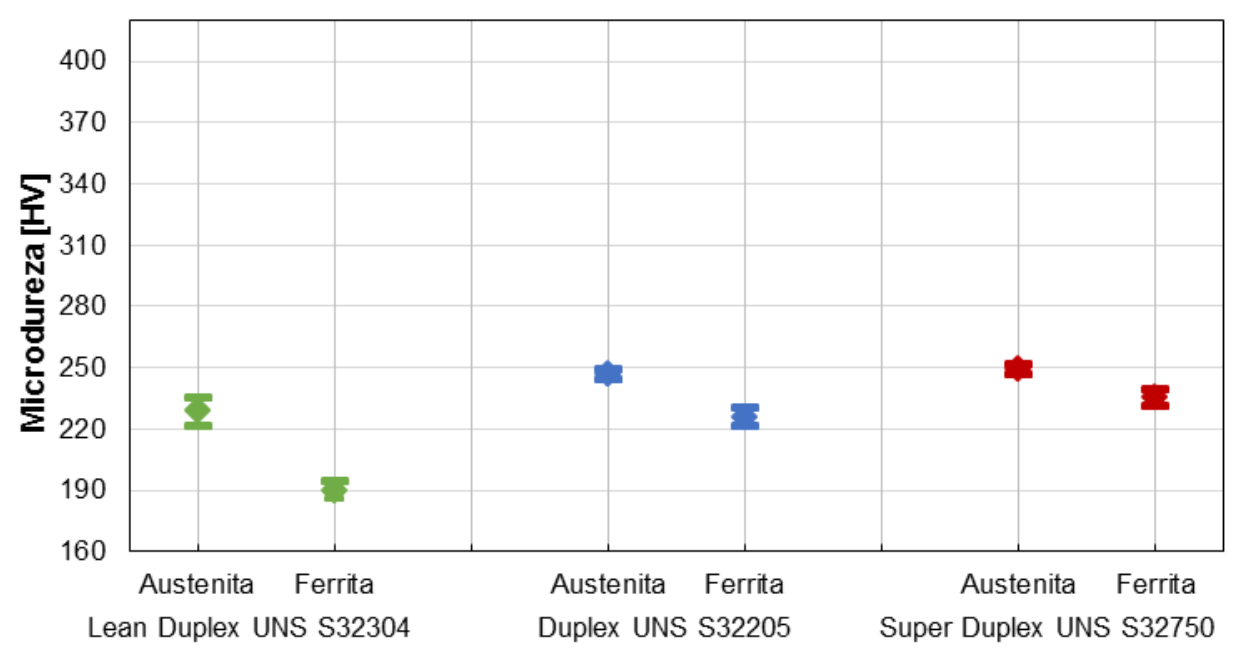

Figura 5-35. Microdureza HV0.01 das fases dos aços AIDs na condição de como-recebido. 
A Figura 5-36 apresenta as micrografias com magnificações de 1000X do aço lean duplex UNS S32304 na condição de como-recebido e exemplifica as indentações com HV0.01 na fases austeníticas e ferrítica.

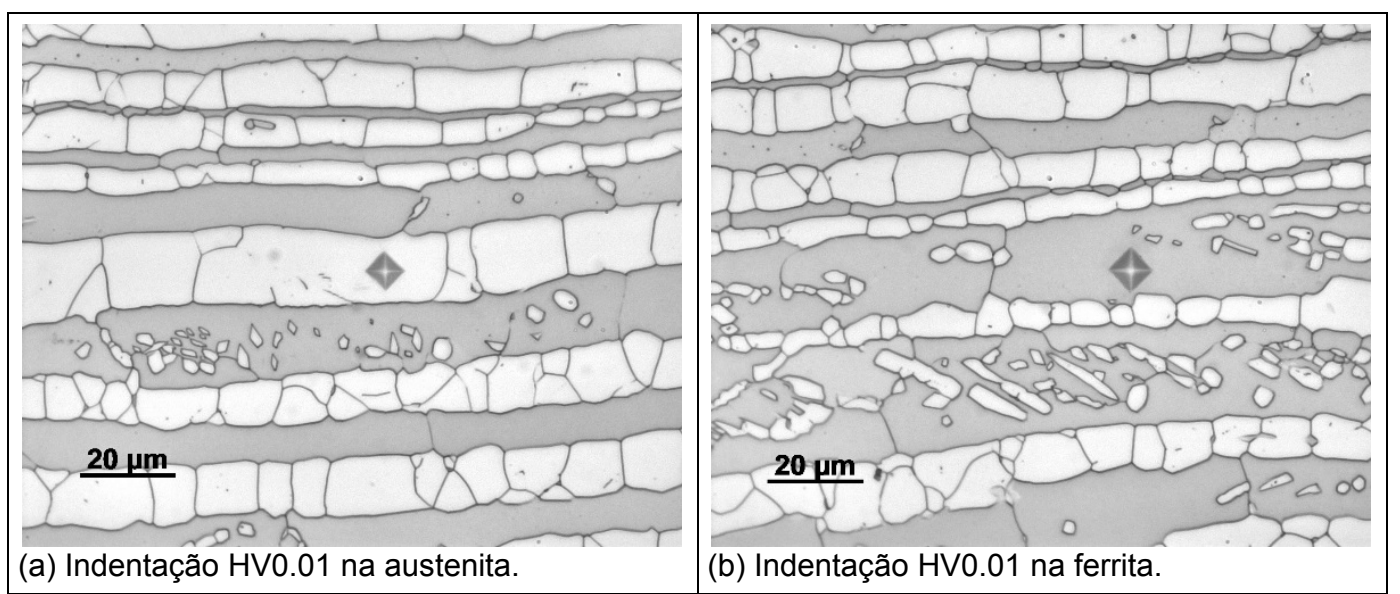

Figura 5-36. Micrografias das indentações HV0.01 nas fases austenita e ferrita do aço lean duplex UNS S32304 na condição de como-recebido.

As fases testadas nas amostras das ZTAs simuladas com aportes de calor 1,0 e $3,0 \mathrm{~kJ} / \mathrm{mm}$ e com têmpera a $250^{\circ} \mathrm{C}$ foram a ferrita no região central dos grãos onde se apresentaram alguns precipitados e poderiam modificar a dureza da fase ferrítica, a ferrita, a austenita de morfologia Widmanstätten ou acicular e a austenita intergranular.

A Tabela 5-20 apresenta as microdurezas das fases mencionadas para as ZTA simuladas com aportes de calor 1,0 e $3,0 \mathrm{~kJ} / \mathrm{mm}$ e com têmpera a $250^{\circ} \mathrm{C}$ dos três AIDs. 
Tabela 5-20. Microdureza HV0.01 das fases nas ZTAs simuladas com aportes de calor de 1,0 e 3,0 $\mathrm{kJ} / \mathrm{mm}$.

\begin{tabular}{|c|c|c|c|c|c|}
\hline & Aporte de Calor & $\begin{array}{c}\text { Austenita } \\
\text { Intergranular }\end{array}$ & $\begin{array}{c}\text { Austenita } \\
\text { Widmanstätten }\end{array}$ & Ferrita & $\begin{array}{c}\text { Ferrita com } \\
\text { Precipitados }\end{array}$ \\
\hline \multirow{2}{*}{$\begin{array}{c}\text { UNS S32304 } \\
\text { (2304) }\end{array}$} & $\begin{array}{c}Q=1.0 \mathrm{~kJ} / \mathrm{mm} \\
\text { Têmpera a } 250^{\circ} \mathrm{C}\end{array}$ & $253 \pm 5$ & $279 \pm 5$ & $211 \pm 5$ & $213 \pm 5$ \\
\cline { 2 - 6 } & $\begin{array}{c}Q=3.0 \mathrm{~kJ} / \mathrm{mm} \\
\text { Têmpera a } 250^{\circ} \mathrm{C}\end{array}$ & $310 \pm 6$ & $338 \pm 8$ & $230 \pm 4$ & $243 \pm 2$ \\
\hline \multirow{2}{*}{$\begin{array}{c}\text { UNS S32205 } \\
\text { (SAF2205) }\end{array}$} & $\begin{array}{c}Q=1.0 \mathrm{~kJ} / \mathrm{mm} \\
\text { Têmpera } \mathrm{a} 250^{\circ} \mathrm{C}\end{array}$ & $300 \pm 8$ & $334 \pm 2$ & $278 \pm 2$ & $307 \pm 7$ \\
\cline { 2 - 6 } & $\begin{array}{c}Q=3.0 \mathrm{~kJ} / \mathrm{mm} \\
\text { Têmpera a } 250^{\circ} \mathrm{C}\end{array}$ & $359 \pm 4$ & $390 \pm 8$ & $311 \pm 9$ & $345 \pm 10$ \\
\hline \multirow{2}{*}{$\begin{array}{c}\text { UNS S32750 } \\
\text { (SAF2507) }\end{array}$} & $\begin{array}{c}Q=1.0 \mathrm{~kJ} / \mathrm{mm} \\
\text { Têmpera a } 250^{\circ} \mathrm{C}\end{array}$ & $337 \pm 7$ & $376 \pm 4$ & $298 \pm 8$ & $337 \pm 10$ \\
\cline { 2 - 6 } & $\begin{array}{c}Q=3.0 \mathrm{~kJ} / \mathrm{mm} \\
\text { Têmpera } \mathrm{a} 250^{\circ} \mathrm{C}\end{array}$ & $318 \pm 8$ & $335 \pm 5$ & $282 \pm 4$ & $292 \pm 14$ \\
\hline
\end{tabular}

As Figuras 5-37, 5-38 e 5-39 apresentam a microdureza para os aços lean duplex UNS S32304, duplex UNS S32205 e super duplex UNS S32750 respectivamente.

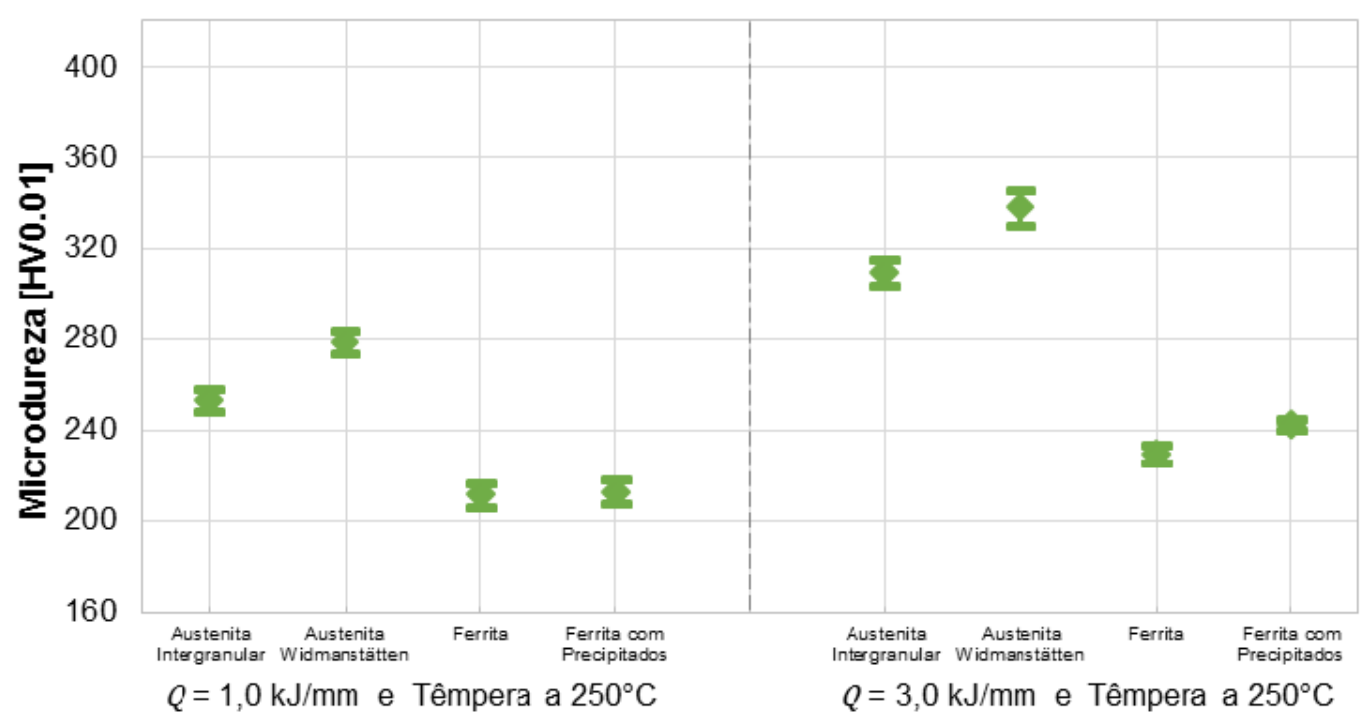

Figura 5-37. Microdurezas HV0.01 das ZTAs simuladas do aço lean duplex UNS S32304. 


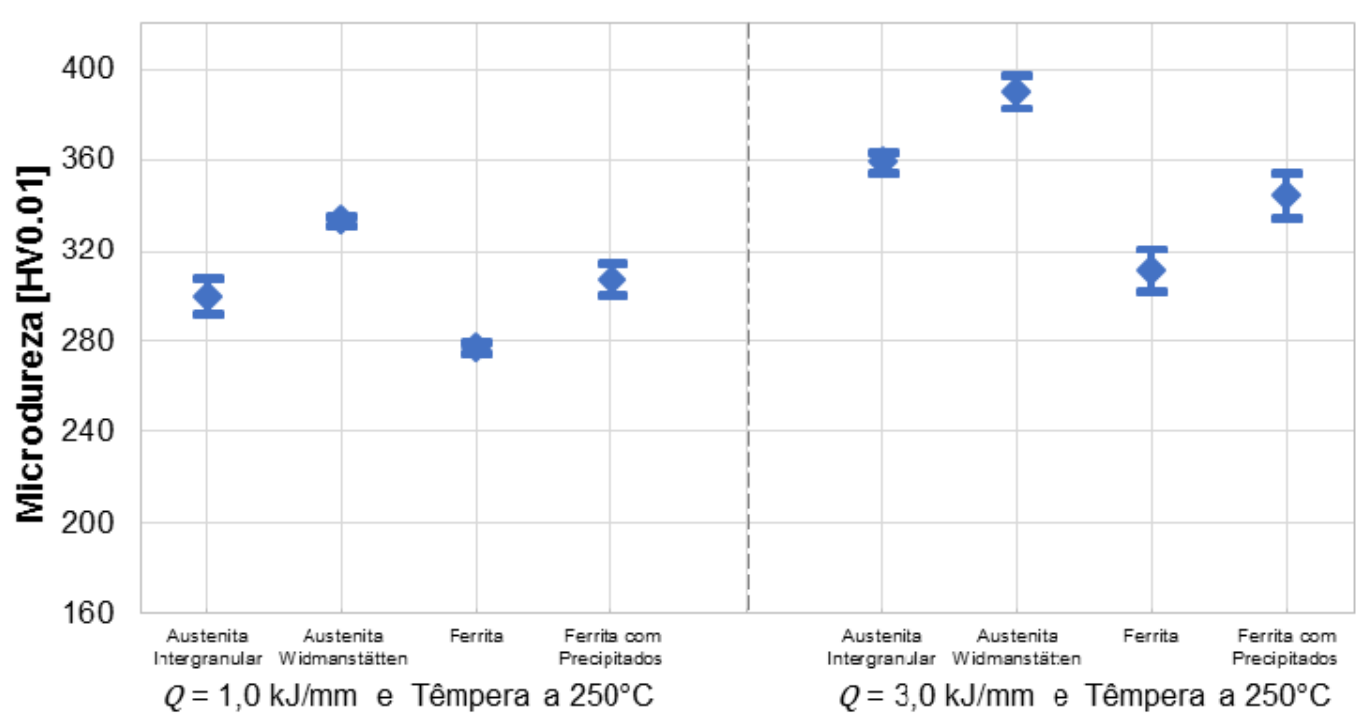

Figura 5-38. Microdurezas HV0.01 das ZTAs simuladas do aço lean duplex UNS S32205.

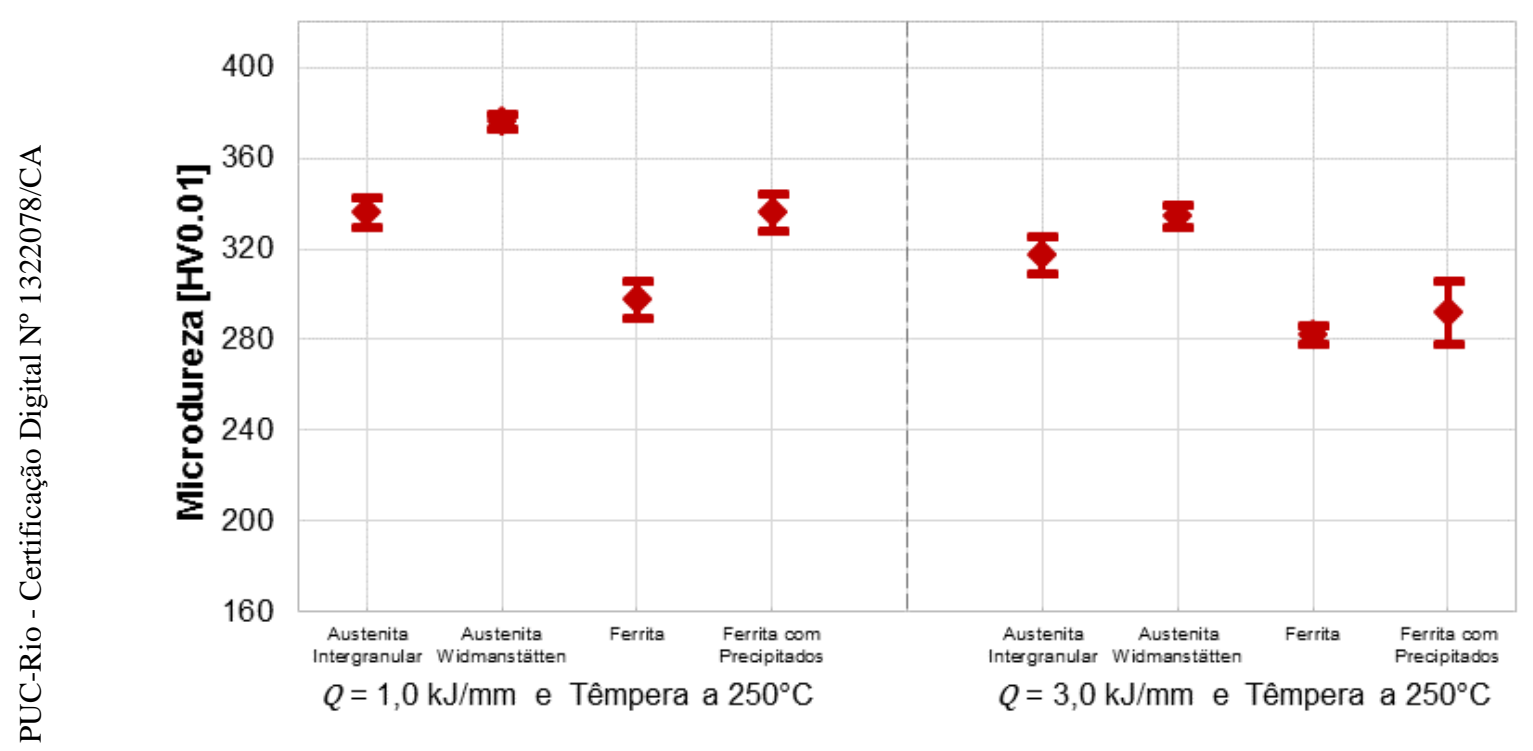

Figura 5-39. Microdurezas HV0.01 das ZTAs simuladas do aço super duplex UNS S32750.

Na Figura 5-40 e na Figura 5-41 são apresentados alguns exemplos das fases ferrítica e austeníticas identadas com HV0.01 nas ZTAs simuladas com aporte de calor de $1,0 \mathrm{~kJ} / \mathrm{mm}$ do aço lean duplex UNS S32304. 


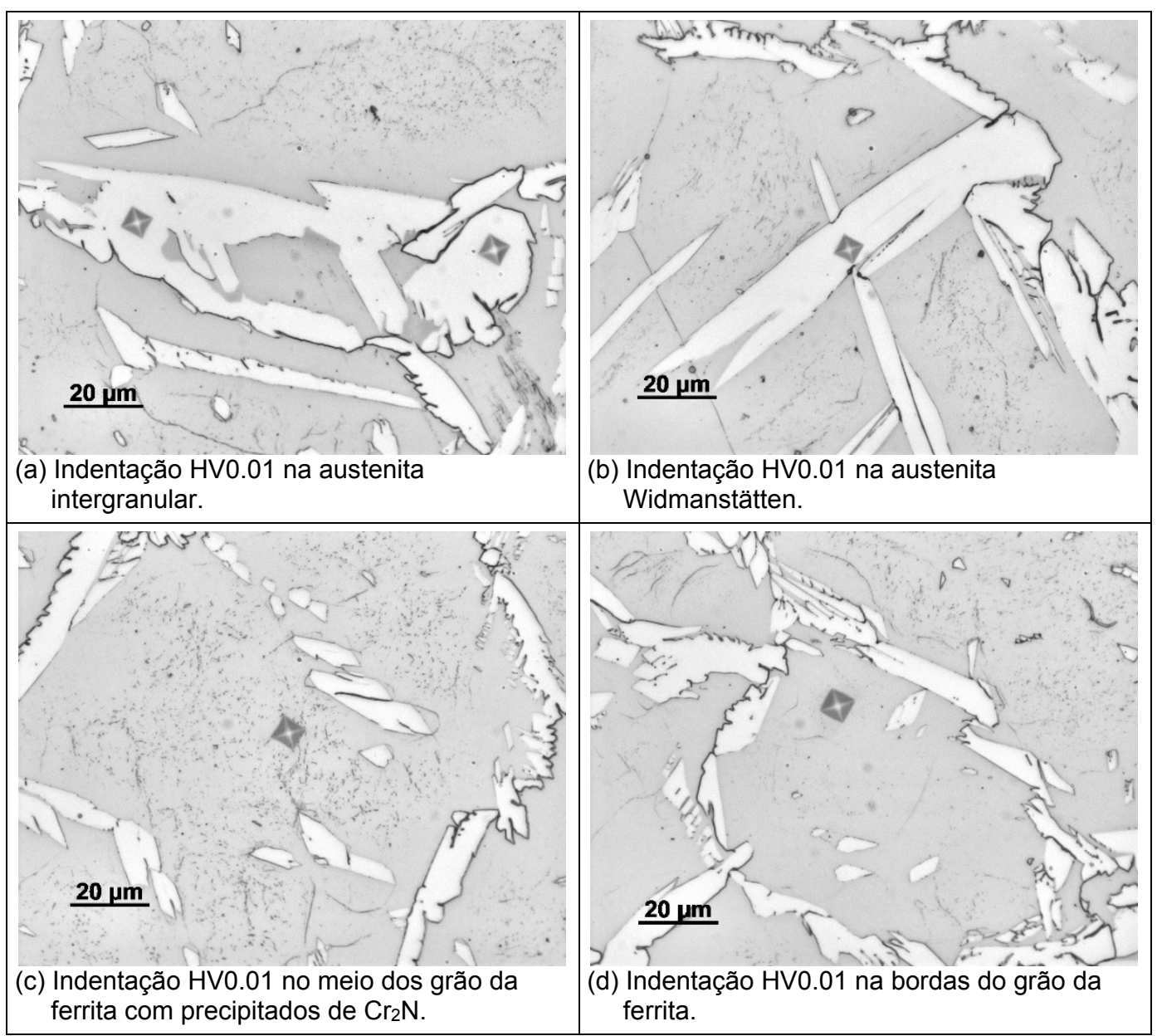

Figura 5-40. Micrografias das indentações HV0.01 nas fases austenítica e ferrítica na ZTA simulada com aporte de calor de $1,0 \mathrm{~kJ} / \mathrm{mm}$ do aço lean duplex UNS S32304. 


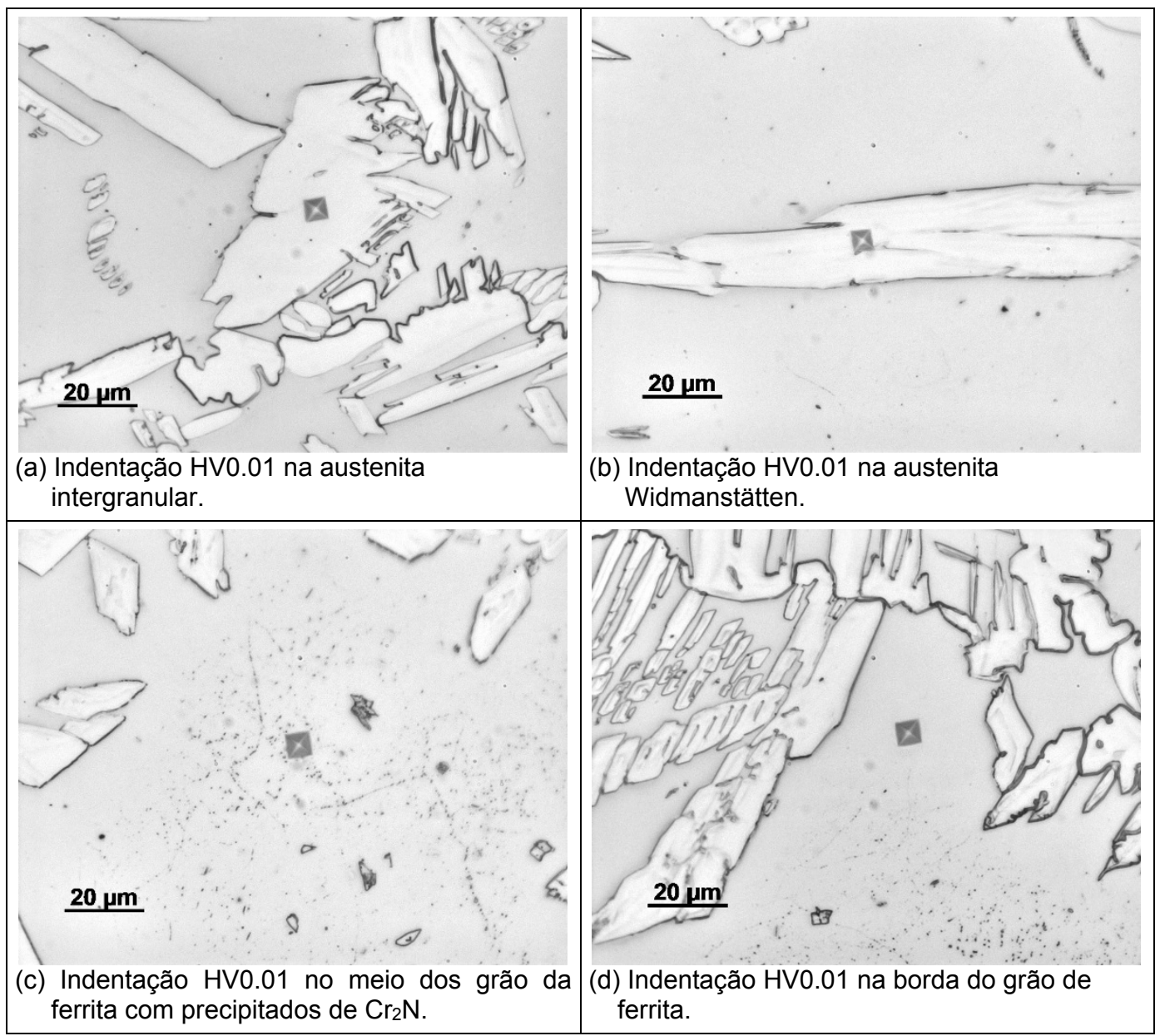

Figura 5-41. Micrografias das indentações HV0.01 nas fases austenítica e ferrítica na ZTA simulada com aporte de calor de 3,0 kJ/mm do aço lean duplex UNS S32304. 
6

\section{Discussão}

\section{1. Influência da Composição Química dos Aços nas Fases que Podem se Formar}

As composições químicas obtidas por análise química instrumental segundo a norma ASTM A240-15 ${ }^{69}$ dos três aços estudados foram apresentadas na Tabela 4-1, assim como as especificações dos fabricantes Aperam (UNS S32304) e Sandvik (UNS S32205 e UNS S32750) na Tabela 4-2.

Quando comparados, os resultados obtidos das análises químicas dos três AIDs em estudo com as especificações da norma e dos fabricantes foram encontrados que alguns teores de elementos estão fora destas especificações (em vermelho na Tabela 6-1). Foi detectado que o teor do nitrogênio no aço inoxidável duplex UNS S32205 é duas vezes maior do especificado.

Tabela 6-1. Composição química dos AIDs em estudo.

\begin{tabular}{|c|c|c|c|c|c|c|c|c|c|c|}
\hline Elemento & $\mathbf{C}$ & $\mathbf{C r}$ & $\mathbf{N i}$ & $\mathbf{M o}$ & $\mathbf{M n}$ & $\mathbf{P}$ & $\mathbf{S}$ & $\mathbf{S i}$ & $\mathbf{C u}$ & $\mathbf{N}$ \\
\hline \multirow{2}{*}{$\begin{array}{c}\mathrm{S} 32304 \\
(2304)\end{array}$} & $\mathbf{0 , 0 2 7}$ & $\mathbf{2 3 , 0 9}$ & $\mathbf{4 , 9 6}$ & $\mathbf{0 , 1 8 2}$ & $\mathbf{1 , 3 8}$ & $\mathbf{0 , 0 2 6}$ & $\mathbf{0 , 0 0 4 2}$ & $\mathbf{0 , 3 3 8}$ & $\mathbf{0 , 4 3 3}$ & $\mathbf{0 , 1 2}$ \\
\cline { 2 - 10 } & 0,028 & $\mathbf{2 6 , 2 0}$ & 5,02 & 0,179 & 1,62 & 0,018 & 0,0038 & 0,398 & 0,395 & 0,11 \\
\hline \multirow{2}{*}{$\begin{array}{c}\text { S32205 } \\
(\mathrm{SAF} 2205)\end{array}$} & $\mathbf{0 , 0 2 5}$ & $\mathbf{2 2 , 4 8}$ & $\mathbf{5 , 2 1}$ & $\mathbf{3 , 2 5}$ & $\mathbf{0 , 8 2}$ & $\mathbf{0 , 0 2 7}$ & $\mathbf{0 , 0 0 4 1}$ & $\mathbf{0 , 4 9 8}$ & $\mathbf{0 , 1 3 2}$ & $\mathbf{0 , 4 0}$ \\
\cline { 2 - 10 } & 0,027 & 22,87 & 5,25 & 3,16 & 0,88 & 0,023 & 0,0041 & 0,477 & $\mathbf{0 , 1 3 7}$ & $\mathbf{0 , 4 2}$ \\
\hline $\begin{array}{c}\text { S32750 } \\
(S A F 2507)\end{array}$ & $\mathbf{0 , 0 2 2}$ & $\mathbf{2 5 , 8 1}$ & $\mathbf{6 , 4 2}$ & $\mathbf{3 , 9 3}$ & $\mathbf{0 , 5 0}$ & $\mathbf{0 , 0 2 6}$ & $\mathbf{0 , 0 0 4 3}$ & $\mathbf{0 , 3 0 0}$ & $\mathbf{0 , 1 4 8}$ & $\mathbf{0 , 2 5}$ \\
\cline { 2 - 10 } & 0,038 & 25,69 & 6,55 & 3,79 & 0,54 & 0,025 & 0,0048 & 0,277 & 0,152 & 0,22 \\
\hline
\end{tabular}

A função do nitrogênio nos AIDs é estabilizar a fase austenítica, e durante a simulação da soldagem esse alto teor de nitrogênio promoverá a estabilização da austenita na ZTA no AID UNS S32205. Os grãos de austenita nucleiam e crescem durante os ciclos de resfriamento programados e o alto teor de nitrogênio saturado na ferrita pode favorecer a precipitação das fases de $\mathrm{Cr}_{2} \mathrm{~N}$ e CrN 95355 .

Nessas mesmas análises químicas do AID UNS S32205, foi verificada a presença de cobre. É sabido que quando os AIDs apresentam elevados teores de cromo, nitrogênio, cobre e tungstênio em combinação com relativamente 
baixos teores de níquel e molibdênio, exibem uma elevada resistência à corrosão especialmente em ambientes ácidos ou básicos com alta presença de cloreto ${ }^{15}$, isso favoreceria a resistência à corrosão deste tipo de aço.

O aço inoxidável lean duplex UNS S32304 apresenta um teor de cromo ligeiramente elevado de $26,20 \%$ (em massa) e o teor máximo especificado pela norma ASTM A240-15 ${ }^{69}$ de 24,5\%. Sendo o cromo um estabilizador da ferrita e também formador de nitretos $\left(\mathrm{Cr}_{2} \mathrm{~N}\right.$ e $\left.\mathrm{CrN}\right)$ indica uma tendência a favorecer a precipitação dessas fases.

Os valores calculados de PRE (PREW $)$ nos AIDs são como o esperado em relação à classificação dos AIDs modernos 2 :

- 25,6 no Aço Lean Duplex 2304 (entre 20 e 30) ${ }^{2}$

- 39,6 no Aço Duplex 2205 (entre 35 e 40) ${ }^{2}$

- 42,8 no Aço Super Duplex 2507 (entre 40 e 50) ${ }^{2}$

Ainda que se apresentem diferenças no teor de nitrogênio, cobre e cromo na composição química do aço inoxidável duplex UNS S32205 e no aço inoxidável lean duplex UNS S32304 em relação às especificações da norma ASTM A240-15 ${ }^{69}$, os valores de $P R E_{W}$ confirmam a classificação de cada um dos aços com base no comportamento da resistência à corrosão por pites.

\section{2 . \\ Efeito da Composição Química na Simulação no Software Thermo- Calc}

Com o uso dos cálculos termodinâmicos computacionais e da base de dados do software Thermo-Calc e das composições da análises químicas determinadas para os aços em estudo, foram obtidos os diagramas de fases de cada dos aços estudados. Isso permitiu considerar as fases que possivelmente estariam presentes nos aços, embora estes cálculos sejam feitos para condições de estabilidade.

Nos diagramas obtidos pode ser observado a presença das fases primárias: ferrita e austenita, além das fases: $\sigma, \pi, \chi, \mathrm{Cr}_{2} \mathrm{~N}$, e $\mathrm{M}_{23} \mathrm{C}_{6}$ (Figura 5-1, Figura 5-2 e Figura 5-3). Estas são as mesmas fases que identificou Calliari em sua pesquisa nesses AIDs ${ }^{50}$.

Os diagramas das frações de fases molares em função da temperatura dos três aços estudados obtidos pelo software Thermo-Calc, em geral apresentaram um comportamento similar: 
- Durante o resfriamento, a primeira fase que solidifica é a ferrita, a faixa de temperatura onde se encontra ferritização completa para os três aços de acordo com o software Thermo-Calc é entre 1352 e $1329^{\circ} \mathrm{C}$, a medida que o resfriamento continua a ferrita começa a se transformar progressivamente em austenita. Na faixa de temperatura de $1275-989^{\circ} \mathrm{C}$ as duas fases primárias: ferrita e austenita, estão em uma relação aproximada de 50:50.

- A formação da fase $\sigma$ ocorre durante o resfriamento, com a solubilização parcial da ferrita que se transforma em fase $\sigma$ e austenita secundária. Com a redução progressiva da temperatura a austenita se transforma parcialmente em ferrita, permanecendo a fase $\sigma$ sem modificações até se dissolver por completo nos três aços estudados aproximadamente a $400^{\circ} \mathrm{C}$.

- A temperaturas inferiores a $400^{\circ} \mathrm{C}$, a microestrutura é basicamente ferrita com frações muito baixas de nitretos e carbonetos, além das fases intermetálicas como a fases $M u, P$ e $\pi$.

Embora existam similaridades, foram identificadas diferenças importantes em cada um dos diagramas de fases dos três AIDs:

- A temperatura máxima do início da formação da fase $\sigma$ aumenta do aço lean duplex, para duplex e super duplex nesta ordem, no aço lean duplex essa temperatura de início de formação de fase $\sigma$ é de $776^{\circ} \mathrm{C}$, para o aço duplex de $874^{\circ} \mathrm{C}$ e para o aço super duplex de $993^{\circ} \mathrm{C}$. O aço super duplex apresenta a fração molar mais alta da fase $\sigma$ com 0,354. A fase $\sigma$ é um composto ternário de $\mathrm{Fe}, \mathrm{Cr}$ e Mo com baixo teor de níquel e manganês ${ }^{56}$, e o aço super duplex é o grau de aço com maior de teor de cromo e molibdênio entre os aços estudados. Além disso se observa que a presença de níquel acelera a cinética de precipitação da fase $\sigma^{1756}$. Portanto, de acordo com esta análise durante o resfriamento a fase $\sigma$ se formaria primeiro e em maior quantidade no aço inoxidável super duplex, no entanto a formação desta fase é dependente de taxa de resfriamento.

- A formação da fase $\chi$ é prevista somente para os aços duplex e super duplex, que são os graus de aço com maior teor de molibdênio (3,25 e 3,93 $\%$ molar de Mo para os aço duplex e super duplex respectivamente). A fase $\chi$ é um composto ternário que contém $\mathrm{Fe}, \mathrm{Cr}$ e Mo. A faixa de temperatura na qual aparece a fase $\chi$ nestes dois graus de aços vai de 923 até $517^{\circ} \mathrm{C}$ 
para o aços duplex e de 790 até $524^{\circ} \mathrm{C}$ para o aços super duplex. De acordo com o software Thermo-Calc a fração molar máxima da fase $\chi$ no aço super duplex com 0,128 , sendo este o grau com o maior teor de molibdênio e cromo.

- A presença de nitretos $\mathrm{Cr}_{2} \mathrm{~N}$ também é prevista nos três aços em estudo, porém como o teor de nitrogênio no aço duplex é superior aquele previsto, a fração molar máxima alcançada de 0,048 a $1098^{\circ} \mathrm{C}$, formando-se primeiro e em maior quantidade no aço inoxidável duplex.

Por definição os AIDs precisam ter na composição química dez elementos dentro das faixas estabelecida pela ASTM ${ }^{69}$, desses dez elementos os mais importantes pelo teor são cromo, níquel, molibdênio e manganês. Estes 4 elementos estão presentes na composição química do aço inoxidável super duplex com teores mais elevados em comparação com os outros dois aços em estudo. O efeito destes elementos nos diagramas de fases simulados no software Thermo-Calc pode ser sumarizado das seguinte forma:

- Cromo e Molibdênio, são elementos estabilizadores da austenita, e se apresentam com o maior teor no aço super duplex, o cromo e o molibdênio promovem a formação da fase $\chi$ e da fase $\sigma$, sendo a previsão das frações destes precipitados maior neste grau de aço.

$\mathrm{O}$ cromo também se encontra nos precipitados de $\mathrm{Cr}_{2} \mathrm{~N}$, mais neste caso o teor de nitrogênio é um fator determinante, sendo a previsão de maior teor de precipitados de $\mathrm{Cr}_{2} \mathrm{~N}$ para o aço duplex em função do maior teor de nitrogênio.

- Níquel e Manganês, estes dois elementos são estabilizadores da fase ferrítica e apresentam os maiores teores no aço super duplex, onde se prevê a maior quantidade de fase $\sigma$. Embora a fase $\sigma$ seja um composto ternário de $\mathrm{Fe}, \mathrm{Cr}$ e Mo também tem um baixo teor de níquel e manganês ${ }^{56}$ e além disso o níquel acelera a cinética de precipitação da fase $\sigma^{17} 56$.

Os resultados da simulação com o software Thermo-Calc, foi apresentada a Tabela 5-4 que mostra uma lista das fases identificadas nos três aços em estudo e a composição delas. Pode-se observar que na composição da fase austenítica e ferrítica estão presentes esses 4 elementos cromo, níquel, molibdênio e manganês. A Tabela 6-2 mostra a previsão da composição das fases ferrítica e austenítica, pode ser verificado que a austenita permite maior teor de elementos 
substitucionais do que a fase ferrítica, portanto a austenita solubiliza em maior proporção em sua estrutura esses 4 elementos avaliados cromo, níquel, molibdênio e manganês.

Tabela 6-2. Previsão da composição das fases ferrítica e austenítica ${ }^{72}$.

\begin{tabular}{|l|l|}
\hline Fase & Composição da Fase \\
\hline $\begin{array}{l}\text { BCC_A2 } \\
\text { (Ferrita) }\end{array}$ & (Al Ca Ce Co Cr Cu Fe Mg Mn Mo Nb Ni P S Si Ta Ti V W Y Zn Zr $)_{1}(\text { B C N O Va })_{3}$ \\
\hline $\begin{array}{l}\text { FCC_A1 } \\
\text { (Austenita) }\end{array}$ & (Al Ca Ce Co Cr Cu Fe Mg Mn Mo Nb Ni P S Si Ta Ti V W Y Zn Zr $)_{1}(\text { B C N O Va })_{1}$ \\
\hline
\end{tabular}

\section{3.}

\section{Efeito do Overshooting na Morfologia das ZTAs Simuladas}

Quando a corrente elétrica passa através de um sistema metálico de seção não uniforme pode ocorrer a temperatura de overshooting. Geralmente com taxas de aquecimento mais rápidas (aporte de calor mais alto) o overshooting é maior. A distribuição de energia está embasada na taxa de aquecimento e é significativamente diferente para aquecimentos muito rápidos e equilíbrio. A distribuição de energia também depende do free span, da resistividade do aço, do tamanho e da forma do corpo de prova ${ }^{102}$.

Quando a região central do corpo de prova (posição do termopar) atinge a temperatura programada, o sistema Gleeble deixa de adicionar mais energia para manter a taxa de aquecimento requerida. A energia localizada na área da seção transversal da região central do corpo de prova é dissipada. Resultando que parte desta energia extra é absorvida pelas garras de cobre e outra parte absorvida pela região central do corpo de prova promovendo um aumento de temperatura (overshooting) ${ }^{102}$.

O valores de overshooting foram obtidos a partir dos dados das curvas executadas e foram calculadas as médias de overshooting para cada conjunto de corpos de prova com as mesmas condições de simulação da ZTA.

A Tabela 6-3 apresenta os valores de overshooting nas temperaturas de pico durante a execução de cada uma das condições das simulações das ZTAs nos três aços estudados. 
Tabela 6-3. Médias dos overshooting nas temperatura de pico durante as simulações das ZTAs nos aços em estudo.

\begin{tabular}{|c|c|c|c|c|c|}
\hline \multicolumn{6}{|c|}{$\begin{array}{l}\text { Aço Inoxidável Lean Duplex } \\
\text { UNS S32304 (2304) }\end{array}$} \\
\hline & $1,0 \mathrm{~kJ} / \mathrm{mm}$ & $1,5 \mathrm{~kJ} / \mathrm{mm}$ & $2,0 \mathrm{~kJ} / \mathrm{mm}$ & $2,5 \mathrm{~kJ} / \mathrm{mm}$ & $3,0 \mathrm{~kJ} / \mathrm{mm}$ \\
\hline $\begin{array}{c}\text { Têmpera em água } \\
\text { a } 500^{\circ} \mathrm{C}\end{array}$ & - & $15^{\circ} \mathrm{C}$ & $13^{\circ} \mathrm{C}$ & $10^{\circ} \mathrm{C}$ & $13^{\circ} \mathrm{C}$ \\
\hline $\begin{array}{l}\text { Têmpera } \\
\text { a } 250^{\circ} \mathrm{C}\end{array}$ & $8^{\circ} \mathrm{C}$ & $10^{\circ} \mathrm{C}$ & $12^{\circ} \mathrm{C}$ & $10^{\circ} \mathrm{C}$ & $10^{\circ} \mathrm{C}$ \\
\hline \multicolumn{6}{|c|}{$\begin{array}{l}\text { Aço Inoxidável Duplex } \\
\text { UNS S32205 (2205) }\end{array}$} \\
\hline & $1,0 \mathrm{~kJ} / \mathrm{mm}$ & $1,5 \mathrm{~kJ} / \mathrm{mm}$ & $2,0 \mathrm{~kJ} / \mathrm{mm}$ & $2,5 \mathrm{~kJ} / \mathrm{mm}$ & $3,0 \mathrm{~kJ} / \mathrm{mm}$ \\
\hline $\begin{array}{c}\text { Têmpera em água } \\
\text { a } 500^{\circ} \mathrm{C}\end{array}$ & - & $10^{\circ} \mathrm{C}$ & $6^{\circ} \mathrm{C}$ & $8^{\circ} \mathrm{C}$ & $9^{\circ} \mathrm{C}$ \\
\hline $\begin{array}{l}\text { Têmpera } \\
\text { a } 250^{\circ} \mathrm{C}\end{array}$ & $3^{\circ} \mathrm{C}$ & $5^{\circ} \mathrm{C}$ & $5^{\circ} \mathrm{C}$ & $6^{\circ} \mathrm{C}$ & $2^{\circ} \mathrm{C}$ \\
\hline \multicolumn{6}{|c|}{$\begin{array}{c}\text { Aço Inoxidável Super Duplex } \\
\text { UNS S32750 (2705) }\end{array}$} \\
\hline & $1,0 \mathrm{~kJ} / \mathrm{mm}$ & $1,5 \mathrm{~kJ} / \mathrm{mm}$ & $2,0 \mathrm{~kJ} / \mathrm{mm}$ & $2,5 \mathrm{~kJ} / \mathrm{mm}$ & $3,0 \mathrm{~kJ} / \mathrm{mm}$ \\
\hline $\begin{array}{c}\text { Têmpera em água } \\
\text { a } 500^{\circ} \mathrm{C}\end{array}$ & - & $13^{\circ} \mathrm{C}$ & $10^{\circ} \mathrm{C}$ & $10^{\circ} \mathrm{C}$ & $10^{\circ} \mathrm{C}$ \\
\hline $\begin{array}{l}\text { Têmpera } \\
\text { a } 250^{\circ} \mathrm{C}\end{array}$ & $6^{\circ} \mathrm{C}$ & $9^{\circ} \mathrm{C}$ & $9^{\circ} \mathrm{C}$ & $9^{\circ} \mathrm{C}$ & $9^{\circ} \mathrm{C}$ \\
\hline
\end{tabular}

O overshooting levou a um aumento (frações de segundo) do tempo de permanência acima da temperatura de pico programada de $1350^{\circ} \mathrm{C}$. Como as temperaturas de overshooting foram relativamente pequenas e durante um tempo de frações de segundos, os corpos de prova não fundiram durante a simulação das ZTAs. A média máxima de overshooting foi de $15^{\circ} \mathrm{C}$ durante a simulação da ZTA no aço lean duplex UNS S32304 com aporte de calor de $1,5 \mathrm{~kJ} / \mathrm{mm}$ e com têmpera em água a $500^{\circ} \mathrm{C}$. Para este conjunto de corpos de prova com as condições mencionadas não ocorreu fusão durante a simulação.

O overshooting é diferente para cada configuração e cada taxa de aquecimento, e depende do material ${ }^{102}$. Os overshooting puderam ser evitados ou ao menos reduzidos fazendo uma correção durante a programação no $H A Z$ software. A correção do overshooting poderia ser realizada com um programa de aproximação que considera a simulação desejada e as medidas de overshooting em um primeiro corpo de prova sacrifício. Durante o aquecimento o overshooting pode ser eliminado subtraindo a energia de excesso por meio de programação. $O$ programa de aproximação é realizado por segmentos subtraindo pouco a pouco a temperatura de excesso e atingindo a simulação desejada ${ }^{102}$.

Os cálculos das médias de overshooting de cada grupo de condições de simulação (Têmpera a $500^{\circ} \mathrm{C}$ e Têmpera $250^{\circ} \mathrm{C}$ ) nos aços em estudo são mostrados na Tabela 6-4. Em geral a média foi de $9,1^{\circ} \mathrm{C}$. Esses valores indicam 
que os tempos de overshooting ocorridos no aço super duplex durante as simulações das ZTAs são valores intermediários entre o aço lean duplex e o aço duplex.

Tabela 6-4. Médias dos overshooting nas temperatura de pico durante as simulações das ZTAs nos aços em estudo.

\begin{tabular}{|c|c|c|c|}
\hline & $\begin{array}{c}\text { Aço Inoxidável Lean } \\
\text { Duplex } \\
\text { UNS S32304 (2304) }\end{array}$ & $\begin{array}{c}\text { Aço Inoxidável } \\
\text { Duplex } \\
\text { UNS S32205 (2205) }\end{array}$ & $\begin{array}{c}\text { Aço Inoxidável Super } \\
\text { Duplex } \\
\text { UNS S32750 (2705) }\end{array}$ \\
\hline $\begin{array}{c}\text { Têmpera em água } \\
\text { a } 500^{\circ} \mathrm{C}\end{array}$ & $12,8^{\circ} \mathrm{C}$ & $8,3^{\circ} \mathrm{C}$ & $10,8^{\circ} \mathrm{C}$ \\
\hline $\begin{array}{c}\text { Têmpera } \\
\text { a } 250^{\circ} \mathrm{C}\end{array}$ & $10,0^{\circ} \mathrm{C}$ & $4,2^{\circ} \mathrm{C}$ & $8,4^{\circ} \mathrm{C}$ \\
\hline
\end{tabular}

A morfologia das fases austenita e ferrita obtidas nas ZTAs simuladas são, como esperado, com algumas diferenças entre elas. A microestrutura formada na ZTA no lean duplex corresponde a austenita lamelar que foi dissolvida completamente e grãos de ferrita grandes com uma quantidade limitada de austenita reformada durante o resfriamento (Figura 6-1 (a)) ${ }^{1}$. No aço duplex a microestrutura da ZTA corresponde à austenita lamelar que foi dissolvida completamente e grãos de ferrita com uma grande quantidade de austenita reformada durante o resfriamento (Figura 6-1 (b)) ${ }^{1}$.

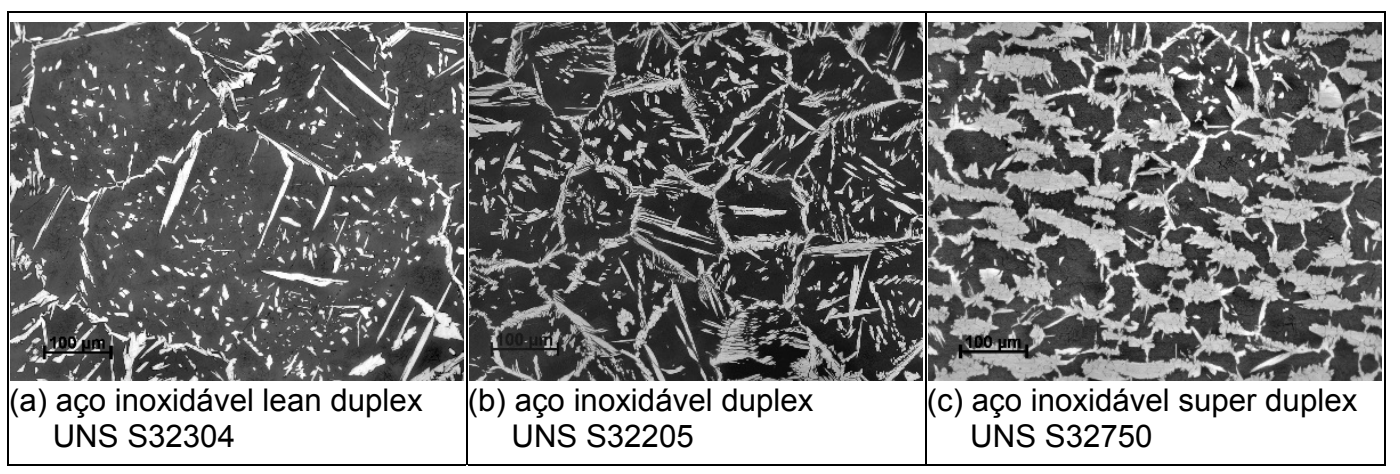

Figura 6-1. Micrografia da ZTA simulada com $1,0 \mathrm{~kJ} / \mathrm{mm}$ com têmpera a $250^{\circ} \mathrm{C}$ no aço inoxidável lean duplex UNS S32304.

No caso da microestrutura da ZTA simulada no aço super duplex, corresponde à austenita parcialmente transformada rodeada de grãos de ferrita que cresceram de maneira limitada (Figura 6-1 (c)) ${ }^{1}$. Embora durante as simulações a temperatura de pico tenha sido atingida como programado, a temperatura foi superada pelo overshooting com uma média para este grau de aço 
de 9,6 s, onde a austenita lamelar não foi dissolvida completamente. Em todas as ZTAs simuladas com diferentes condições de aporte de aporte de calor se observou a mesmo tipo de microestrutura. Foi possível também identificar a direção de laminação do processo de fabricação do tubo de aço super duplex nas ZTAs simuladas (em direção horizontal na Figura 6-2), o que indica que a austenita não foi dissolvida completamente. Isto ocorreu somente para este grau de aço, e não por causa da temperatura de pico mas pelo tempo mantido na temperatura de pico durante as simulações. O ângulo de Feret dos grãos de austenita foi medido em todas as micrografias das ZTAs simuladas no aço inoxidável super duplex como mostrado na Tabela 6-6, com uma média de 17 graus medido desde a horizontal. As imagens capturadas no microscópio ótico foram preferencialmente obtidas com os grãos de austenita posicionados na direção horizontal. Aqui o ângulo de Feret indica a direção preferencial de deformação dos grãos de austenita como consequência da fabricação ainda depois da simulação das ZTAs.

Tabela 6-5. Ângulo de Feret dos grãos de austenita das ZTAs simuladas no aço inoxidável super duplex medido desde a horizontal.

\begin{tabular}{|c|c|c|c|c|c|}
\hline & $\mathbf{1 , 0} \mathbf{~ k J / m m}$ & $\mathbf{1 , 5} \mathbf{~ k J / m m}$ & $\mathbf{2 , 0} \mathbf{~ k J / m m}$ & $\mathbf{2 , 5} \mathbf{~ k J / m m}$ & $\mathbf{3 , 0} \mathbf{~ k J} / \mathbf{m m}$ \\
\hline $\begin{array}{c}\text { Têmpera em água } \\
\text { a } 500^{\circ} \mathbf{C}\end{array}$ & 12,8 & 15,0 & 17,7 & 16,4 & 7,2 \\
\hline $\begin{array}{c}\text { Têmpera } \\
\text { a } 250^{\circ} \mathbf{C}\end{array}$ & - & 20,6 & 11,0 & 25,8 & 17,8 \\
\hline
\end{tabular}

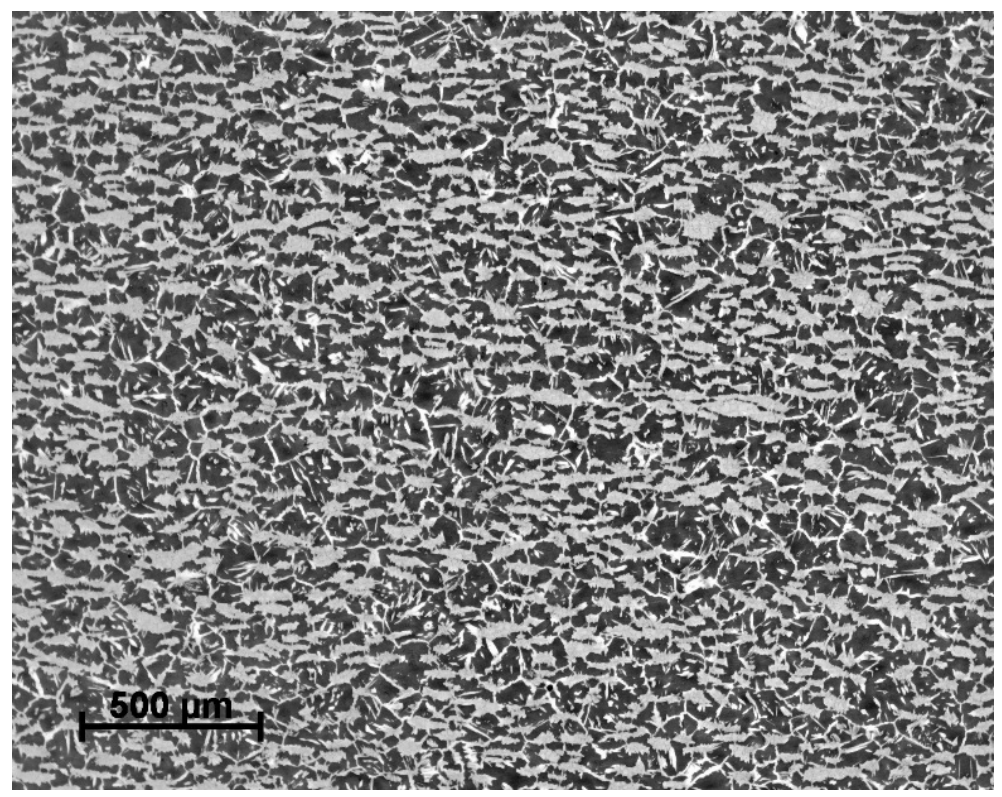

Figura 6-2. Direção de laminação da ZTA simulada com $1,0 \mathrm{~kJ} / \mathrm{mm}$ com têmpera a $250^{\circ} \mathrm{C}$ no aço inoxidável super duplex UNS S32750 com aumento de 50X. 


\section{4 . \\ Caraterização Metalográfica}

A evolução microestrutural das fases primárias durante o aumento do aporte de calor nas simulações das ZTAs para o aço lean duplex (Figura 5-10) mostra que a ferrita apresentou uma redução na fração volumétrica das fases variando entre 0,817 e 0,780 quando o aporte de calor aumenta de 1,5 a 3,0 kJ/mm com têmpera em água a $500^{\circ} \mathrm{C}$ (Figura 5-15), e de 0,816 até 0,756 de ferrita quando o aporte aumenta de 1,0 até $3,0 \mathrm{~kJ} / \mathrm{mm}$ com têmpera a $250^{\circ} \mathrm{C}$ (Figura 5-16).

Em todas as condições de simulação da ZTA no aço lean duplex a fração volumétrica de ferrita foi alta em relação à fração volumétrica de ferrita do aço na condição de como-recebido $(0,593)$. Afetando o comportamento mecânico e a microdureza neste grau de aço.

Por outro lado, as ZTAs simuladas nos aços duplex e super duplex mantiveram um balanço de fases mais próximo do 50:50 especialmente no aço super duplex como mostrado anteriormente nas Figuras 5-17 e 5-18 para o aço duplex e nas Figuras 5-19 e 5-20 para o aço super duplex.

Essa maior fração de ferrita nas ZTAs simuladas no aço lean duplex não é devido ao teor de $\mathrm{Cr}$ neste grau de aço. Em comparação com outros dois aços, o aço lean duplex tem os teores de cromo intermediários. Embora o cromo seja um elemento estabilizador da ferrita assim como também são o molibdênio e o alumínio que estão presentes com teores menores neste aço lean duplex.

A alta fração volumétrica da ferrita nas ZTAs simuladas no aço lean duplex é devido ao fato que na simulação das ZTAs o tempo na temperatura de pico foi suficiente para atingir a ferritização completa, apresentado um tamanho de grão de ferrita maior do que aquele encontrado nos outros dois aços avaliados. No caso do aço super duplex, o tempo de $2 \mathrm{~s}$ na temperatura de pico não foi suficiente para dissolver a austenita lamelar ${ }^{1}$ toda presente no aço na condição de comorecebido.

Foram observados precipitados de $\mathrm{Cr}_{2} \mathrm{~N}$ por meio de ataque eletrolítico com solução de $\mathrm{HNO}_{3}$ na região central dos grãos de ferrita e precipitados de $\mathrm{CrN}$ na interface austenita / ferrita 67132655 nas amostras das ZTAs simuladas com baixo aporte de calor $(1,0 \mathrm{~kJ} / \mathrm{mm})$ onde a taxa de resfriamento foi a mais rápida $\left(\Delta t_{12 / 8}=6,7 \mathrm{~s}\right)$. Para estas taxas de resfriamento mais rápidas não há tempo para que o cromo e o nitrogênio sejam dissolvidos na ferrita, a qual fica saturada formando estes precipitados nesta condição de simulação de ZTA. O crescimento dos precipitados de $\mathrm{Cr}_{2} \mathrm{~N}$ é controlado pela difusão unidimensional do $\mathrm{Cr}$ desde o 
centro dos grãos da ferrita para o contorno de grão ${ }^{103}$. Uma consequência do empobrecimento da ferrita nesses dois elementos é a redução da resistência à corrosão local.

Tem sido reportado que o nitreto do tipo $\mathrm{CrN}$ tende a precipitar em paralelo ao nitreto do tipo $\mathrm{Cr}_{2} \mathrm{~N}$ especialmente com as taxas de resfriamento altas nas interfaces ferrita / austenita 1055 .

\section{5.}

\section{Efeito da Taxa de Resfriamento no Tamanho de Grão da Ferrita}

O diâmetro dos grãos da ferrita aumenta quando se aumenta o aporte de calor durante a simulação das ZTAs que está relacionado proporcionalmente com os tempos $\Delta t_{12 / 8}$ e $\Delta t_{8 / 5}$ (Figura 6-3).

As simulações das ZTAs do primeiro grupo de corpos de prova (têmpera em água a $500^{\circ} \mathrm{C}$ ) com aporte de calor alto de $3,0 \mathrm{~kJ} / \mathrm{mm}$, os tempos $\Delta t_{12 / 8}$ e $\Delta t_{8 / 5}$ são 4 vezes maiores do que os tempos $\Delta t_{12 / 8}$ e $\Delta t_{8 / 5}$ correspondentes às simulações das ZTAs com aporte de calor baixo de $1,5 \mathrm{~kJ} / \mathrm{mm}$ como mostrado na Tabela 6-6. No segundo grupo de corpos de prova (têmpera a $250^{\circ} \mathrm{C}$ ) os tempos $\Delta t_{12 / 8}$ e $\Delta t_{8 / 5}$ dos aportes de $3,0 \mathrm{~kJ} / \mathrm{mm}$ são 9 vezes maiores do que os tempos $\Delta t_{12 / 8}$ e $\Delta t_{8 / 5}$ dos aportes de $1,0 \mathrm{~kJ} / \mathrm{mm}$ (Tabela 6-7).

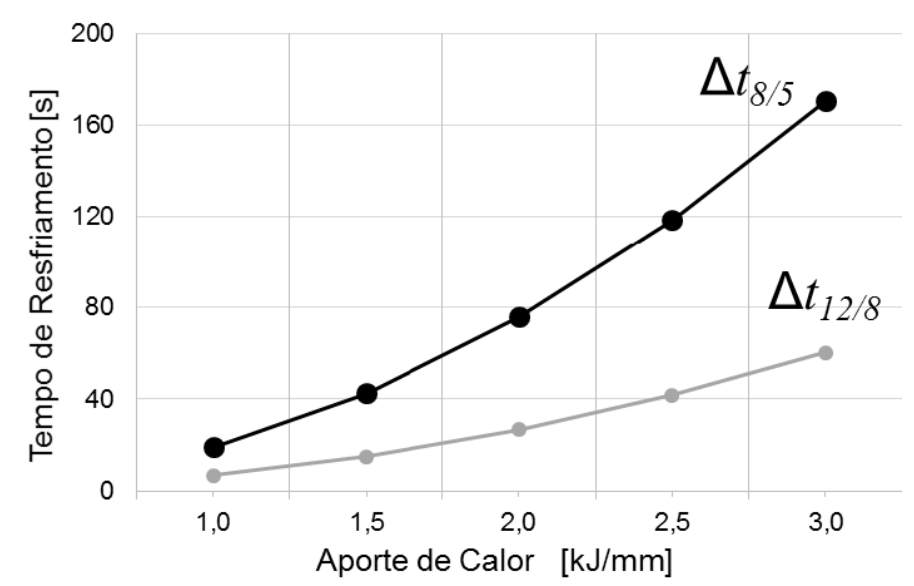

Figura 6-3. Relação dos tempos de resfriamento $\Delta t_{8 / 5}$ e $\Delta t_{12 / 8}$ vs aporte de calor para uma chapa de $10 \mathrm{~mm}$ de espessura.

Para o aporte de calor alto de $3,0 \mathrm{~kJ} / \mathrm{mm}$ ofereceu maior tempo de resfriamento $\left(\Delta t_{12 / 8}=60,2 \mathrm{~s}\right)$ permitindo que os grãos de ferrita e austenita cresçam, conforme esperado. 
O tamanho de grão da ferrita é uma função do aporte de calor usado durante a simulação das ZTAs, o que é equivalente a dizer que o tamanho de grão da ferrita é uma função dos tempos $\Delta t_{12 / 8}, \Delta t_{8 / 5}$, isso é representado para cada um dos aços lean duplex, duplex e super duplex nas Figuras 5-21, 5-22 e 5-23 respectivamente e mostrado nas Tabelas 6-6 e 6-7.

Com um $\Delta t_{12 / 8}$ de $60,2 \mathrm{~s}$ (o maior tempo programado para as simulações das ZTAs com 3,0 kJ/mm) o tamanho do grão de ferrita obtido nos três aços são os maiores em todas as condições de simulação da ZTA, da mesma maneira com $\Delta t_{12 / 8}$ de 6,7 s que foi o menor tempo programado o tamanho da ferrita é o menor obtido em todas as condições de simulação da ZTA.

Esse comportamento do crescimento de grão proporcional aos aportes de calor (e aos tempos $\Delta t_{12 / 8}$ e $\Delta t_{8 / 5}$ ) durante a simulação das ZTAs (Figuras 6-4, 6-5 e 6-6) mostra que o crescimento do grão da ferrita é muito mais susceptível para aço inoxidável lean duplex do que o aço inoxidável super duplex. As inclinações da relação tamanho de grão da ferrita vs aporte de calor (taxas de resfriamento) são maiores no aço lean duplex.

Tabela 6-6. Correlação de aportes de calor, $\Delta t_{12 / 8}$, e taxa de resfriamento com o tamanho de grão da ferrita nos aços em estudo durante a simulação das ZTAs com têmpera em água a $500^{\circ} \mathrm{C}$.

\begin{tabular}{|c|c|c|c|c|c|}
\hline $\begin{array}{c}\text { Aporte de } \\
\text { Calor, } \\
{[\mathrm{kJ} / \mathrm{mm}]}\end{array}$ & $\begin{array}{c}\Delta t_{12 / 8}, \\
{[\mathbf{s}]}\end{array}$ & $\begin{array}{c}\Delta t_{8 / 5}, \\
{[\mathbf{s}]}\end{array}$ & $\begin{array}{c}\text { Tamanho de Grão da } \\
\text { Ferrita, } \\
\text { Lean Duplex 2304 } \\
{[\mu \mathrm{m}]}\end{array}$ & $\begin{array}{c}\text { Tamanho de Grão da } \\
\text { Ferrita, } \\
\text { Duplex 2205 } \\
{[\mu \mathrm{m}]}\end{array}$ & $\begin{array}{c}\text { Tamanho de Grão da } \\
\text { Ferrita, } \\
\text { Super Duplex 2507, } \\
{[\mu \mathrm{m}]}\end{array}$ \\
\hline 1,5 & 15,0 & 42,6 & $385 \pm 11$ & $179 \pm 6$ & $124 \pm 6$ \\
\hline 2,0 & 26,8 & 75,8 & $451 \pm 10$ & $278 \pm 7$ & $130 \pm 5$ \\
\hline 2,5 & 41,8 & 118,4 & $517 \pm 11$ & $346 \pm 8$ & $152 \pm 4$ \\
\hline 3,0 & 60,2 & 170,5 & $660 \pm 13$ & $391 \pm 11$ & $175 \pm 5$ \\
\hline
\end{tabular}

Tabela 6-7. Correlação de aportes de calor, $\Delta t_{12 / 8}$, e taxas de resfriamento com o tamanho de grão da ferrita nos aços em estudo durante a simulação das ZTAs com têmpera a $250^{\circ} \mathrm{C}$.

\begin{tabular}{|c|c|c|c|c|c|}
\hline $\begin{array}{l}\text { Aporte de } \\
\text { Calor, } \\
{[\mathrm{kJ} / \mathrm{mm}]}\end{array}$ & $\begin{array}{c}\Delta t_{12 / 8}, \\
{[\mathbf{s}]}\end{array}$ & $\begin{array}{c}\Delta t_{8 / 5}, \\
{[\mathbf{s}]}\end{array}$ & $\begin{array}{c}\text { Tamanho de Grão da } \\
\text { Ferrita, } \\
\text { Lean Duplex } 2304[\mu \mathrm{m}]\end{array}$ & $\begin{array}{c}\text { Tamanho de Grão da } \\
\text { Ferrita, } \\
\text { Duplex 2205 } \\
{[\mu \mathrm{m}]}\end{array}$ & $\begin{array}{c}\text { Tamanho de Grão da } \\
\text { Ferrita, } \\
\text { Super Duplex 2507, } \\
{[\mu \mathrm{m}]}\end{array}$ \\
\hline 1,0 & 6,7 & 18,9 & $275 \pm 7$ & $191 \pm 5$ & $91 \pm 3$ \\
\hline 1,5 & 15,0 & 42,6 & $343 \pm 12$ & $202 \pm 6$ & $129 \pm 3$ \\
\hline 2,0 & 26,8 & 75,8 & $502 \pm 15$ & $260 \pm 12$ & $131 \pm 4$ \\
\hline 2,5 & 41,8 & 118,4 & $712 \pm 15$ & $317 \pm 12$ & $161 \pm 4$ \\
\hline 3,0 & 60,2 & 170,5 & $740 \pm 16$ & $430 \pm 12$ & $162 \pm 4$ \\
\hline
\end{tabular}




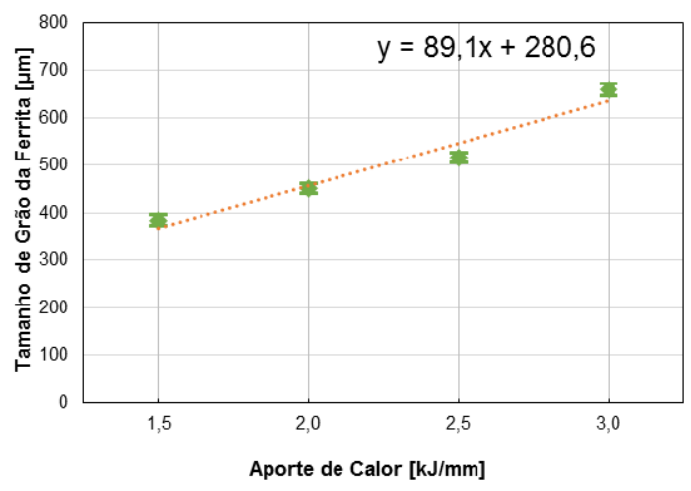

(a) Têmpera em água a $500^{\circ} \mathrm{C}$.

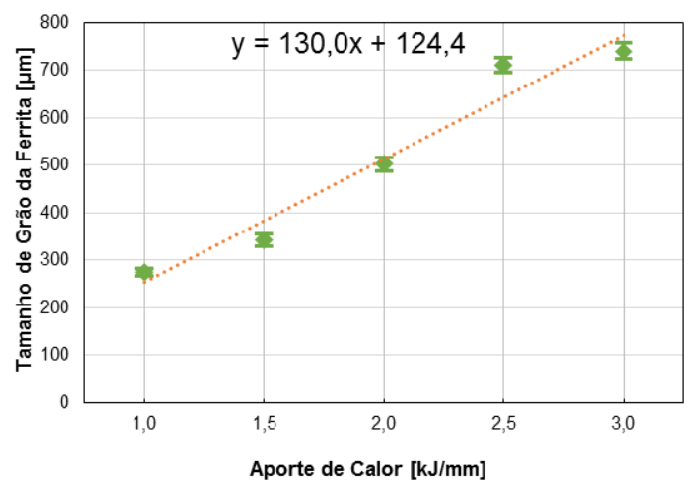

(b) Têmpera a $250^{\circ} \mathrm{C}$.

Figura 6-4. Diagramas de aporte de calor vs tamanho de grão da ferrita durante a simulação das ZTAs no aço inoxidável lean duplex UNS S32304.

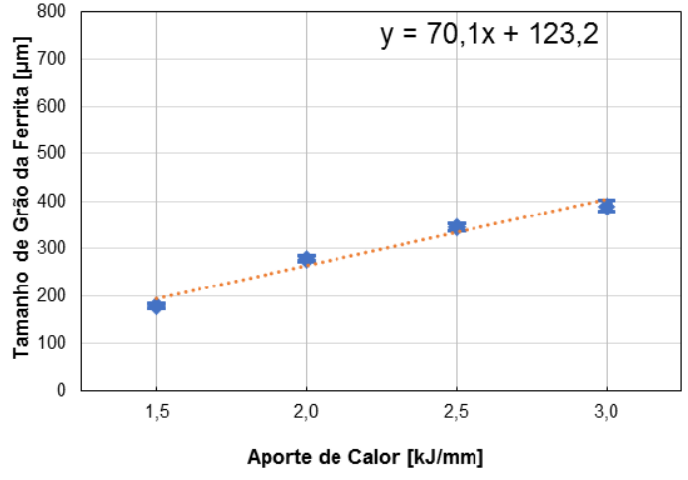

(a) Têmpera em água a $500^{\circ} \mathrm{C}$.

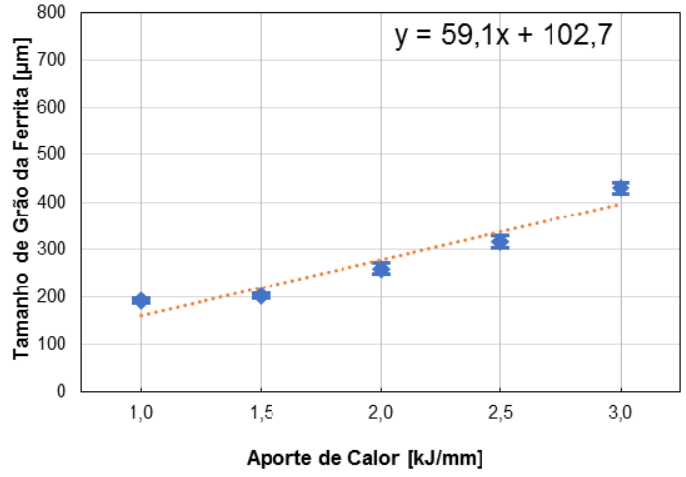

(b) Têmpera a $250^{\circ} \mathrm{C}$.

Figura 6-5. Diagramas de aporte de calor vs tamanho de grão da ferrita durante a simulação das ZTAs no aço inoxidável lean duplex UNS S32205.

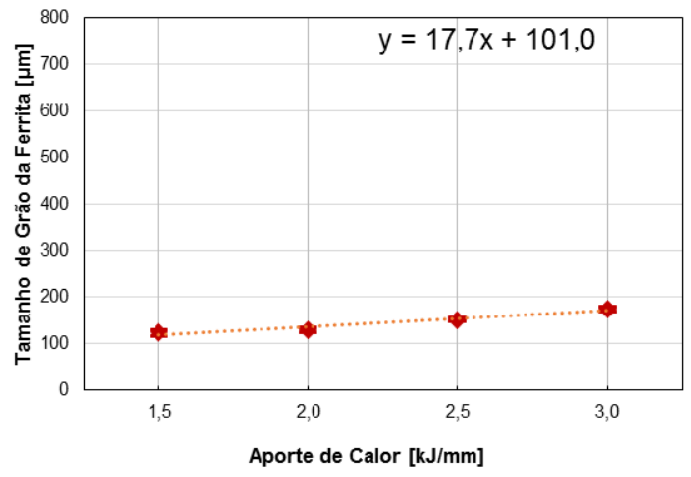

(a) Têmpera em água a $500^{\circ} \mathrm{C}$.

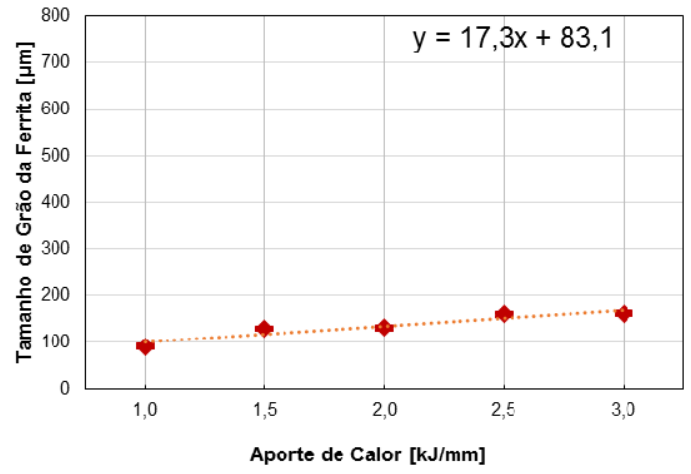

(b) Têmpera a $250^{\circ} \mathrm{C}$.

Figura 6-6. Diagramas de aporte de calor vs tamanho de grão da ferrita durante a simulação das ZTAs no aço inoxidável lean duplex UNS S32750. 
A importância de conhecer o comportamento do tamanho de grão devido à simulação das ZTAs é porque o tamanho de grão está relacionado com outras propriedades como a dureza e a resistência. Um material com granulação fina é mais duro e mais resistente do que um material que possui uma granulação grosseira, uma vez que o primeiro possui um área total maior de contornos de grão para impedir o movimento das discordâncias ${ }^{96}$.

De acordo com a Equação de Hall-Petch o tamanho de grão está relacionado com a tensão limite de escoamento ${ }^{96}$ mostrada na Equação 6-1, mais precisamente a resistência das ZTAs é degradada em certa medida devido ao crescimento dos grãos da ferrita.

$\sigma_{y}=\sigma_{0}+k_{y} d^{1 / 2}$

Equação 6-1

Onde:

$\sigma_{y}=$ tensão limite de escoamento

$d$ = diâmetro médio do grão

$\sigma_{0}$ e $k_{y}=$ constantes específicas para cada material.

A Equação Hall-Petch não é válida para os materiais policristalinos com grãos de tamanho muito grandes ou com grãos extremadamente finos. Para as ZTAs simuladas essa equação não tem validade, Na Figura 6-7 são representadas as curvas Limite de escoamento vs Tamanho de grão da Ferrita $\left(d^{-1 / 2}\right)$ para os três aços em estudo, e o comportamento não é linear como esperado. Isso ocorre porque o tamanho de grão nas ZTAs é muito pequeno (em escala micrométrica) como o requerido pela equação (em escala milimétrica) ${ }^{96}$. 


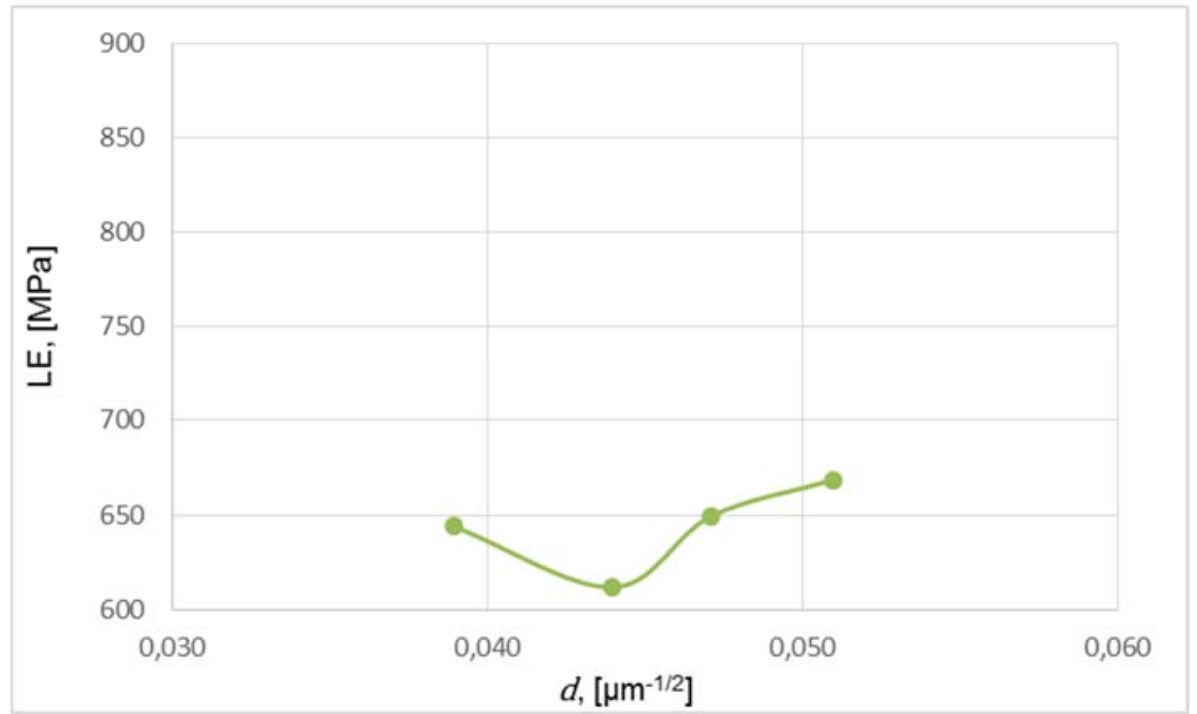

(a) Aço inoxidável lean duplex UNS S32304

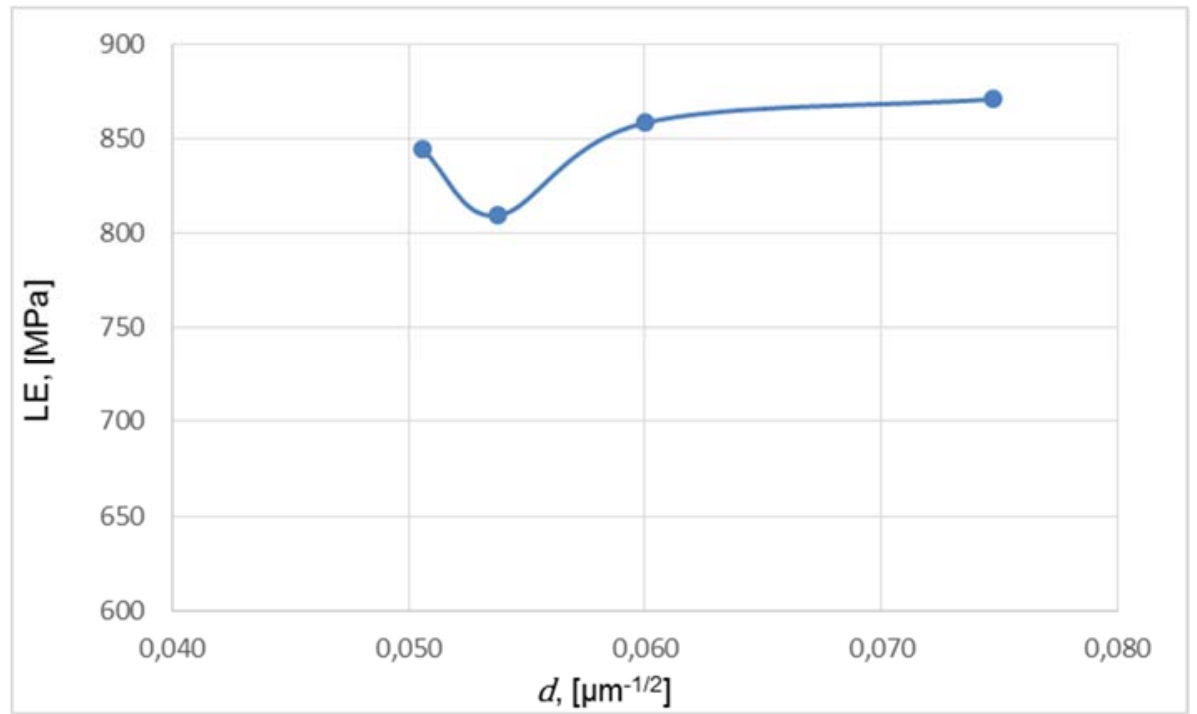

(b) Aço inoxidável duplex UNS S32205

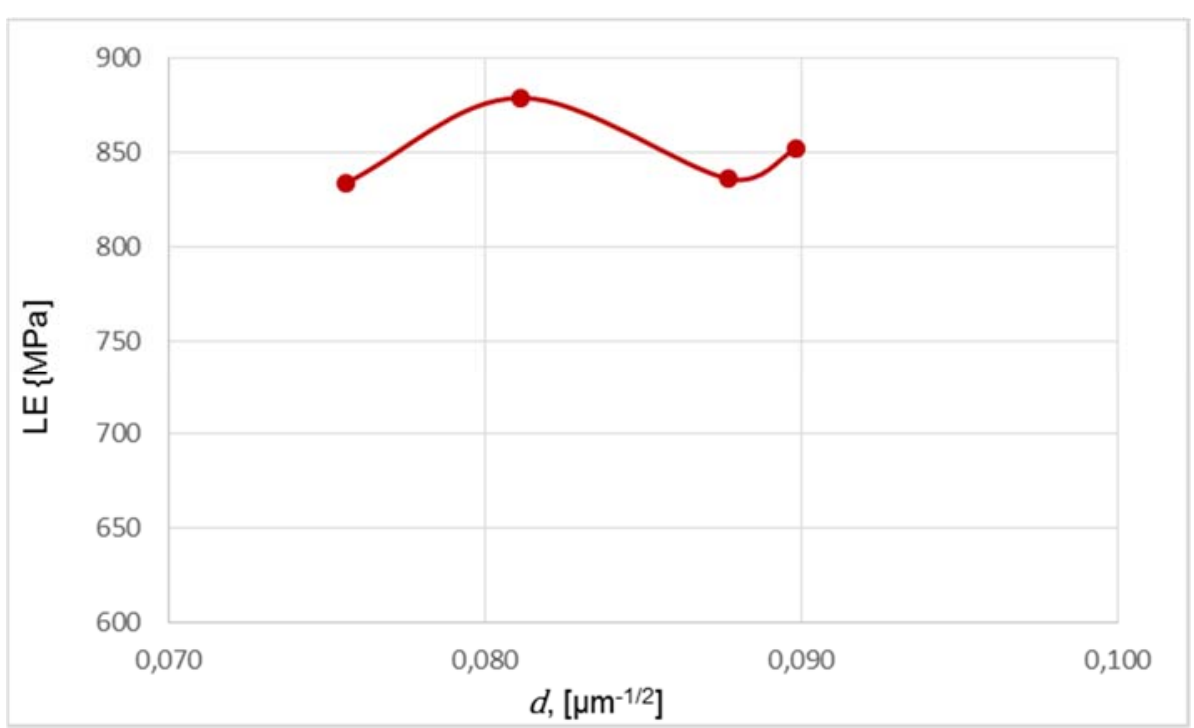

(c) Aço inoxidável super duplex UNS S32750

Figura 6-7. Limite de escoamento vs tamanho de grão de ferrita para as ZTAs simuladas nos três aços em estudo, grupo de corpos de prova com têmpera em água a $500^{\circ} \mathrm{C}$. 


\section{6. Efeito da Taxa de Resfriamento na Fração Volumétrica da Austenita nas ZTAs Simuladas}

A fração volumétrica da austenita nas ZTAs simuladas aumenta com o aumento do aporte de calor, isso foi mostrado nas figuras da Contagem de Fases no item 5.4.2, sendo portanto uma função dos tempos $\Delta t_{12 / 8}$ e $\Delta t_{8 / 5}$ (Figura 6-4).

As Figuras 6-8, 6-9 e 6-10 mostram especificamente este comportamento para a fase austenítica em todas as condições de simulação das ZTAs nos três aços estudados e as Tabelas 6-6 e 6-7 relacionam os aportes de calor, os tempos de resfriamento $\Delta t_{12 / 8}$ e $\Delta t_{8 / 5}$, e as frações volumétricas de austenita em todas a condições de simulação das ZTAs.

Com um $\Delta t_{12 / 8}$ de $60,2 \mathrm{~s}$ (o maior tempo $\Delta t_{12 / 8}$ programado para as simulações das ZTAs) foram obtidas as maiores frações de austenita em cada um dos três aços em estudo, de igual maneira com o tempo $\Delta t_{12 / 8}$ de $6,7 \mathrm{~s}$ que foi o menor tempo programado as menores frações de austenita foram obtidas nos três aços.

O aço super duplex foi o aço que apresentou maior fração volumétrica de austenita quando comparado em qualquer condição de simulação da ZTA com os outros dois aços. Como os parâmetros de simulação das ZTAs foram as mesmas para os três aços, esse comportamento de alta fração volumétrica de austenita no aço super duplex é devido à composição química deste aço, rico em níquel que favorece à estabilização desta fase.

O aumento progressivo da fração volumétrica da fase austenítica quando o tempo $\Delta t_{12 / 8}$ é incrementado, é evidenciado no aumento da espessura dos grãos de austenita. As agulhas de austenita Widmanstätten se tornam mais espessas e os grãos de austenita intergranular também exibem um crescimento proporcional ao tempo de resfriamento $\Delta t_{12 / 8}$ e ao aporte de calor. 


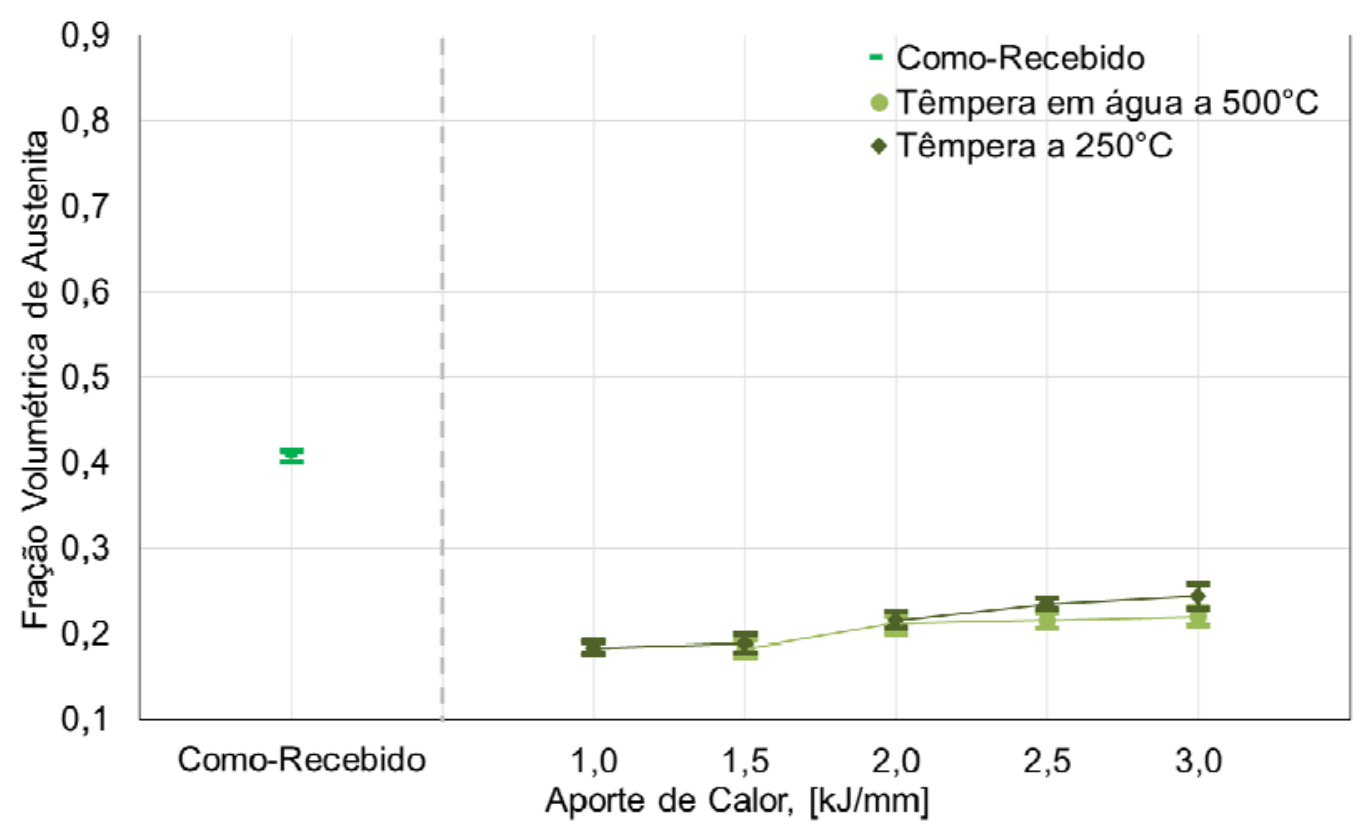

Figura 6-8. Diagrama de fração volumétrica da austenita vs aporte de calor durante a simulação das ZTAs no aço inoxidável super duplex UNS S32304.

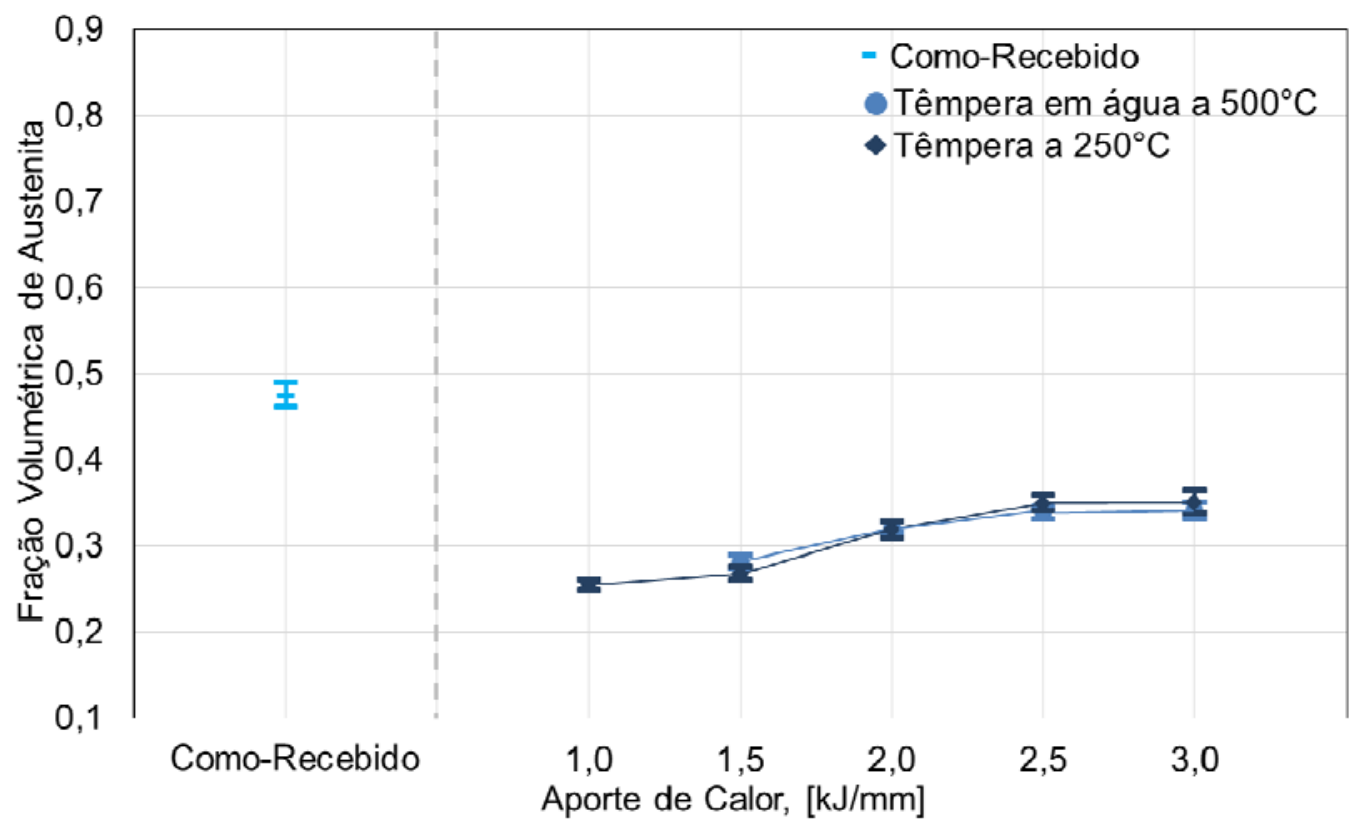

Figura 6-9. Diagrama de fração volumétrica da austenita vs aporte de calor durante a simulação das ZTAs no aço inoxidável duplex UNS S32205. 


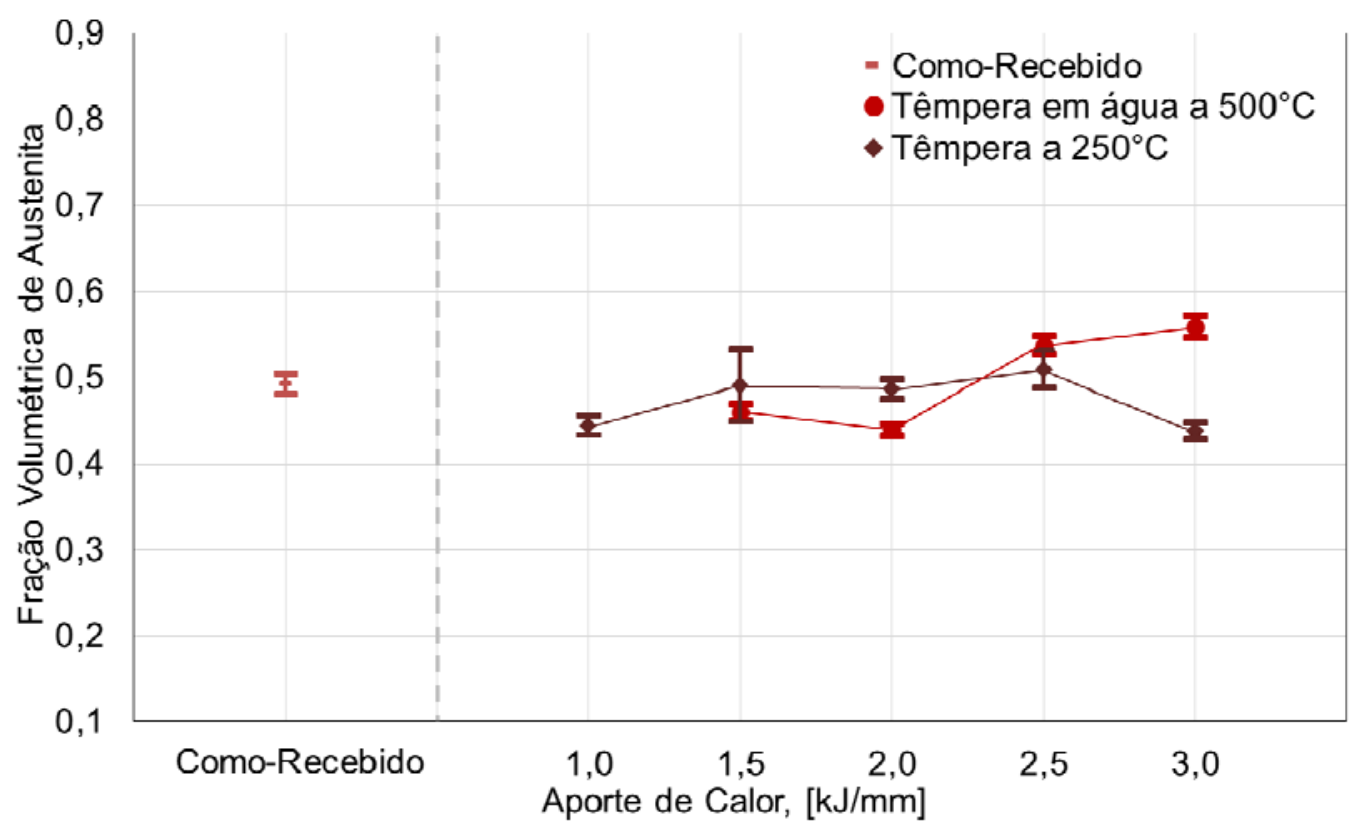

Figura 6-10. Diagrama de fração volumétrica da austenita vs aporte de calor durante a simulação das ZTAs no aço inoxidável super duplex UNS S32750.

Tabela 6-8. Correlação de aportes de calor, $\Delta t_{12 / 8}$, e taxa de resfriamento com a fração volumétrica da austenita nos aços em estudo durante a simulação das ZTAs com têmpera em água a $500^{\circ} \mathrm{C}$.

\begin{tabular}{|c|c|c|c|c|c|}
\hline $\begin{array}{c}\text { Aporte de } \\
\text { Calor, } \\
{[\mathrm{kJ} / \mathrm{mm}]}\end{array}$ & $\begin{array}{c}\Delta t_{12 / 8,}, \\
{[\mathbf{s}]}\end{array}$ & $\begin{array}{c}\Delta t_{8 / 5}, \\
{[\mathbf{s}]}\end{array}$ & $\begin{array}{c}\text { Fração Volumétrica de } \\
\text { Austenita, } \\
\text { Lean Duplex 2304 }\end{array}$ & $\begin{array}{c}\text { Fração Volumétrica de } \\
\text { Austenita, } \\
\text { Duplex 2205 }\end{array}$ & $\begin{array}{c}\text { Fração Volumétrica de } \\
\text { Austenita, } \\
\text { Super Duplex 2507 }\end{array}$ \\
\hline 1,5 & 15 & 42,6 & $0,183 \pm 0,010$ & $0,281 \pm 0,007$ & $0,460 \pm 0,011$ \\
\hline 2,0 & 26,8 & 75,8 & $0,210 \pm 0,010$ & $0,320 \pm 0,006$ & $0,439 \pm 0,007$ \\
\hline 2,5 & 41,8 & 118,4 & $0,215 \pm 0,009$ & $0,339 \pm 0,007$ & $0,538 \pm 0,010$ \\
\hline 3,0 & 60,2 & 170,5 & $0,220 \pm 0,010$ & $0,341 \pm 0,009$ & $0,559 \pm 0,012$ \\
\hline
\end{tabular}

Tabela 6-9. Correlação de aportes de calor, $\Delta t_{12 / 8}$, e taxas de resfriamento com a fração volumétrica da austenita nos aços em estudo durante a simulação das ZTAs com têmpera a $250^{\circ} \mathrm{C}$.

\begin{tabular}{|c|c|c|c|c|c|}
\hline $\begin{array}{c}\text { Aporte de } \\
\text { Calor, } \\
{[\mathbf{k J} / \mathbf{m m}]}\end{array}$ & $\begin{array}{c}\Delta t_{12 / 8}, \\
{[\mathbf{s}]}\end{array}$ & $\begin{array}{c}\Delta t_{8 / 5}, \\
{[\mathbf{s}]}\end{array}$ & $\begin{array}{c}\text { Fração Volumétrica de } \\
\text { Austenita, } \\
\text { Lean Duplex 2304 }\end{array}$ & $\begin{array}{c}\text { Fração Volumétrica de } \\
\text { Austenita, } \\
\text { Duplex 2205 }\end{array}$ & $\begin{array}{c}\text { Fração Volumétrica de } \\
\text { Austenita, } \\
\text { Super Duplex 2507 }\end{array}$ \\
\hline 1,0 & 6,7 & 18,9 & $0,184 \pm 0,007$ & $0,255 \pm 0,006$ & $0,444 \pm 0,011$ \\
\hline 1,5 & 15 & 42,6 & $0,189 \pm 0,011$ & $0,267 \pm 0,008$ & $0,491 \pm 0,042$ \\
\hline 2,0 & 26,8 & 75,8 & $0,216 \pm 0,009$ & $0,318 \pm 0,009$ & $0,487 \pm 0,012$ \\
\hline 2,5 & 41,8 & 118,4 & $0,235 \pm 0,007$ & $0,349 \pm 0,009$ & $0,509 \pm 0,021$ \\
\hline 3,0 & 60,2 & 170,5 & $0,244 \pm 0,014$ & $0,351 \pm 0,013$ & $0,438 \pm 0,010$ \\
\hline
\end{tabular}




\section{7. Efeito da Fração Volumétrica da Austenita na Caracterização Mecânica}

Quando todos os testes de tração mecânica dos aços na condição de comorecebido e das ZTAs simuladas foram comparados nas Figuras 5-28 e 5-29, foi evidente que o comportamento do aço inoxidável lean duplex foi diferente aos outros dois aços. O aço lean duplex em estado como-recebido apresenta os limites de escoamento e de resistência menores dos três aços em estudo, e além disso estas duas propriedades das ZTAs simuladas no aço lean duplex são ainda menor do que no estado no estado sem simulação. Embora tanto os valores no estado como-recebido quanto nas ZTAs simuladas foram maiores dos especificados pela norma ASTM A240 (400 MPa e 600 MPa mínimos para limite de escoamento e de resistência respectivamente).

O limite de escoamento das ZTAs simuladas no aço lean duplex apresentou uma redução de 22,2\% (de 826,8 MPa da condição como-recebido para 643,4 MPa da média das ZTAs simuladas). Esta redução foi acompanhada pela redução no limite de resistência em 27,5\% (de 952,5 MPa para 690,6 MPa). Esse comportamento está associado à redução na fração volumétrica da austenita na microestrutura em 49,1\% (de 0,407 de austenita (lamelar e intragranular) na condição de como-recebido para 0,207 de austenita (Widmanstätten, intragranular e intergranular) na média das ZTAs simuladas). Além disso, como já se mencionou essa redução na fração volumétrica da austenita está associada aos tempos de resfriamento $\Delta t_{12 / 8}$ durante as simulações das ZTAs que ainda são curtos para permitir após da dissolução da austenita, a reformação e crescimento dos grãos de austenita.

O limite de escoamento e o limite de resistência das ZTAs simuladas nos aços duplex e aços super duplex se mantiveram levemente menor do que os valores dos aços na condição de como-recebido (Figuras 6-12 e 6-13).

A relação entre os aportes de calor, fração volumétrica da austenita na microestrutura e o comportamento mecânico (limite de escoamento e de resistência) dos aços na condição de como-recebido e das ZTAs simuladas para os aços lean duplex, duplex e super duplex respectivamente são apresentados nas Figuras 6-11, 6-12 e 6-13 e mostram como esperado, que o aço inoxidável super duplex apresenta o valor maior de limite de escoamento e de limite de resistência quando comparado com as ZTAs simuladas nos outros dois AIDs. Estes valores maiores de limite de escoamento e limite de resistência (na ZTA 
com aporte de calor de $2,5 \mathrm{~kJ} / \mathrm{mm}$ e têmpera em água a $500^{\circ} \mathrm{C}$ ) no aço super duplex correspondem à maior fração volumétrica de austenita na microestrutura (0,538 de Austenita), entre os três aços em estudo tanto na condição de comorecebido quanto nas ZTAs simuladas.

O aço super duplex na condição de como-recebido possui um fração de 0,492 de Austenita (lamelar e intragranular) e nas ZTAs simuladas do primeiro grupo de corpos de prova (têmpera em água a $500^{\circ} \mathrm{C}$ ) se calculou a média 0,499 de fração volumétrica de austenita (Widmanstätten, intragranular e intergranular). O efeito desses valores de fração volumétrica de austenita influíram levemente no limite de escoamento e de resistência com uma redução de $8,4 \%$ e de $11,4 \%$ respectivamente entre o aço na condição como-recebido e a média das propriedades mecânicas das ZTAs simuladas (Figura 6-13).

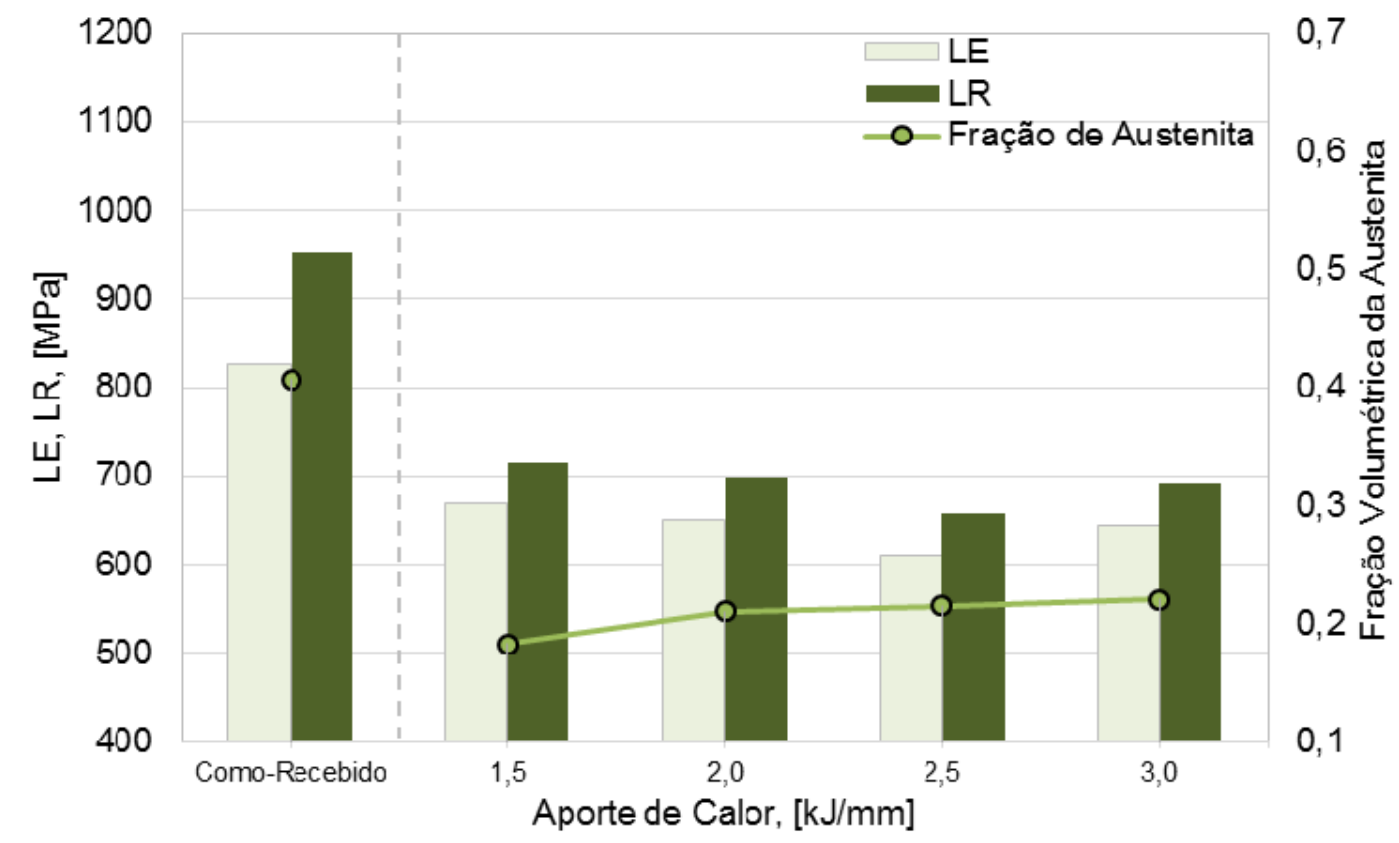

Figura 6-11. Relação das propriedades mecânicas com a fração volumétrica da austenita no aço inoxidável lean duplex UNS S32304. 


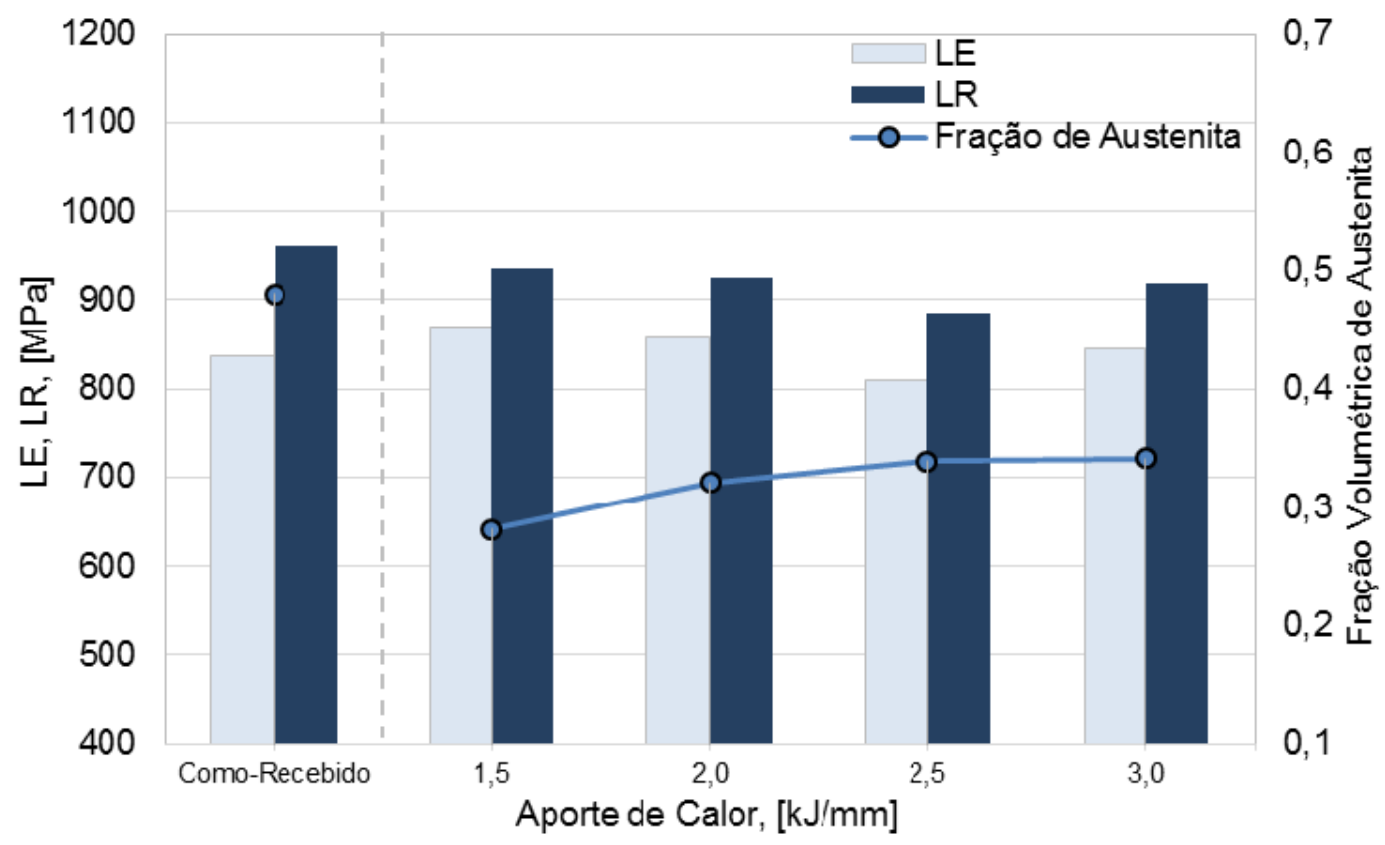

Figura 6-12. Relação das propriedades mecânicas com a fração volumétrica da austenita no aço inoxidável duplex UNS S32205.

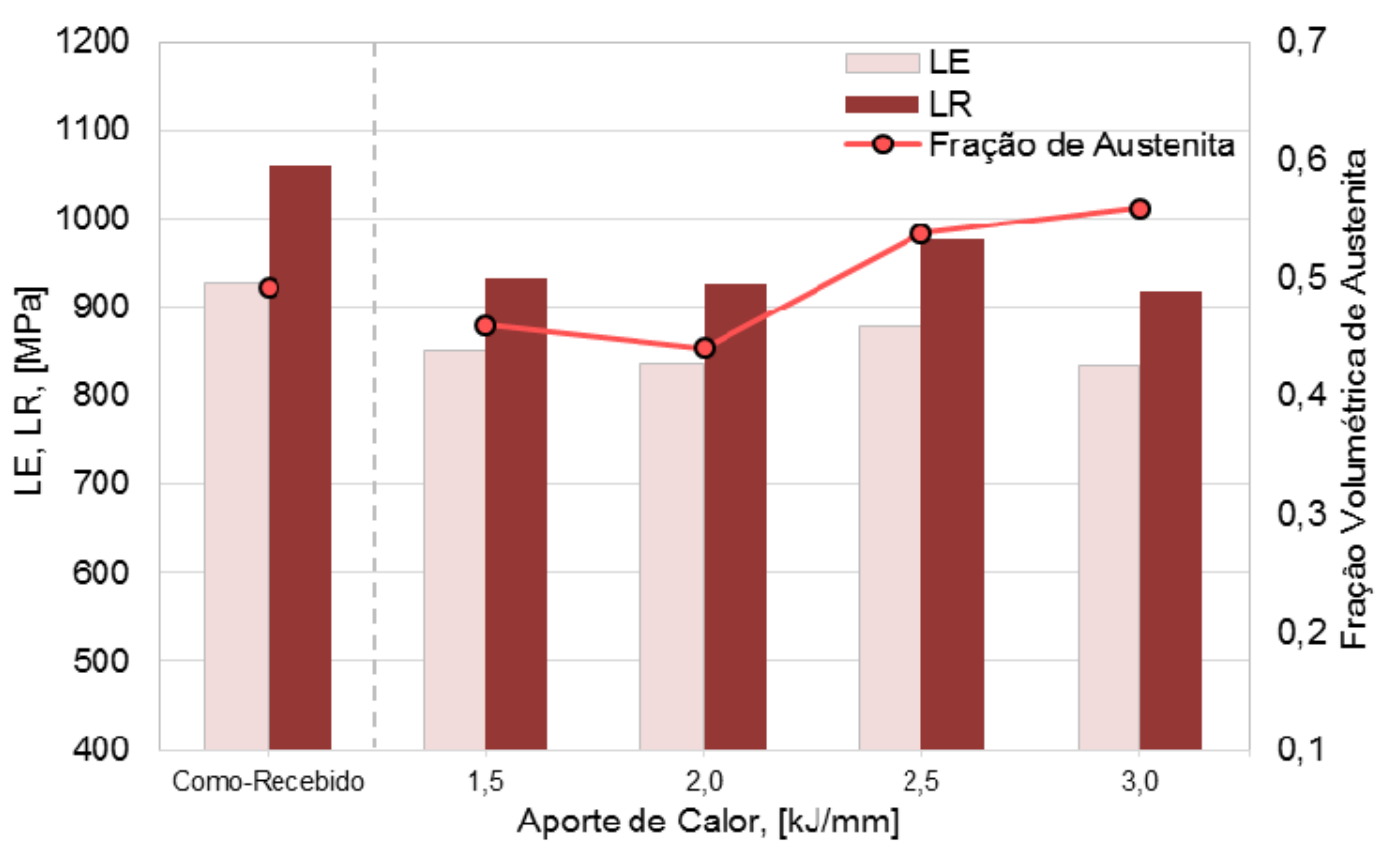

Figura 6-13. Relação das propriedades mecânicas com a fração volumétrica da austenita no aço inoxidável super duplex UNS S32750.

\section{8.}

\section{Efeito da Taxa de Resfriamento na Microdureza}

A microdureza HV1 utiliza a maior carga que contempla este tipo de ensaio (1000 gf). A indentação, é portanto, relativamente grande e mede a microdureza geral do aço considerando o efeito de todas as fases presentes. 
As medidas de microdureza no aço lean duplex apresentaram um comportamento moderadamente diferente do que os aços duplex e super duplex. As média das microdurezas das ZTAs simuladas no aço lean duplex com aporte de calor baixo $(1,0 \mathrm{~kJ} / \mathrm{mm})$ e alto $(3,0 \mathrm{~kJ} / \mathrm{mm})$ e com têmpera a $250^{\circ} \mathrm{C}$ foram quase iguais, em torno de $1 \%$ menor do que a microdureza do aço na condição de comorecebido. Poderão estar dentro do erro experimental e portanto pode ser considerada que não houve variação.

As médias das microdurezas das ZTAs simuladas com baixo e alto aporte de calor e têmpera a $250^{\circ} \mathrm{C}$ nos aços duplex e super duplex foram maiores do que nos aços na condição de como-recebido em 5,6\% e 17,3\% respectivamente.

As ZTAs simuladas no aço inoxidável super duplex tiveram as frações volumétricas de austenita maiores de todas as condições de simulação e por ser uma fase mais dura do que a ferrita, os valores de microdureza HV1 foram os maiores em todas as condições de simulação. As Figuras 6-14, 6-15 e 6-16 apresentam a relação entre as microdurezas [HV1] e a fração volumétrica da austenita com o aporte de calor (e consequentemente com o tempo de resfriamento $\left.\Delta t_{12 / 8}\right)$.

Como foi mostrado na contagem de fases (5.4.2) a fração volumétrica de austenita nas ZTAs simuladas aumenta quando o aporte de calor é incrementado (e com o incremento do tempo de resfriamento $\Delta t_{12 / 8}$ ). Quando comparada a fração volumétrica da austenita nas ZTAs simuladas e o aporte de calor programado com a microdureza HV1 das ZTAs simuladas se encontra que o valor da microdureza não é substancialmente alterado. Os valores de microdureza permaneceram na faixa de 227 a 231 HV1 no aço lean duplex, de 269 e 257 HV1 para o aço duplex e de 289 a 288 HV1 para o aço super duplex, estes valores podem ser considerados quase constantes porque tem pouca variação entre eles.

O maior efeito dos tempos de resfriamento $\Delta t_{12 / 8}$ é evidenciado nas ZTAs simuladas no aço lean duplex, onde com um aumento de aporte de calor de 1,0 até $3,0 \mathrm{~kJ} / \mathrm{mm}$ (equivalente a um aumento de $\Delta t_{12 / 8}$ de $6,7 \mathrm{~s}$ a $60,2 \mathrm{~s}$ ) a fração volumétrica da austenita se aumentou em $32,6 \%$ (de 0,184 para 0,244 ) e se obteve um aumento da microdureza da ZTA de 227 a 331 HV1.

Se esperaria que as ZTAs simuladas com alto aporte de calor $(3,0 \mathrm{~kJ} / \mathrm{mm})$ onde se obtém a maior fração volumétrica da austenita fossem mais duras devido ao fato que a fase austenítica é mais dura do que a matriz ferrítica. Porém os ciclos térmicos com baixo aporte de calor $(1,0 \mathrm{~kJ} / \mathrm{mm})$ equivalente a tempos de resfriamentos curtos ocasionaram a precipitação de $\mathrm{Cr}_{2} \mathrm{~N}$. 


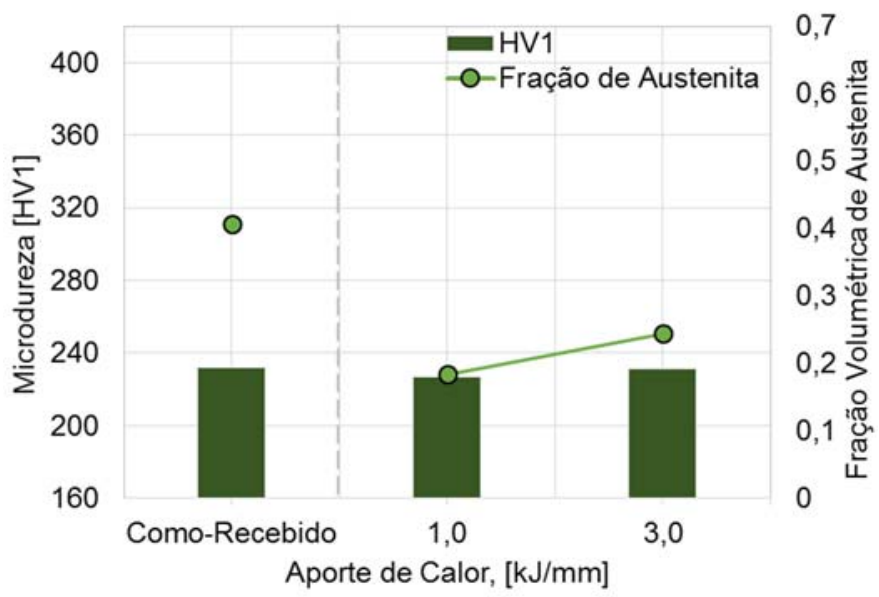

Figura 6-14. Relação entre microdureza [HV1], fração volumétrica de austenita e aporte de calor no aço inoxidável lean duplex UNS S32304.

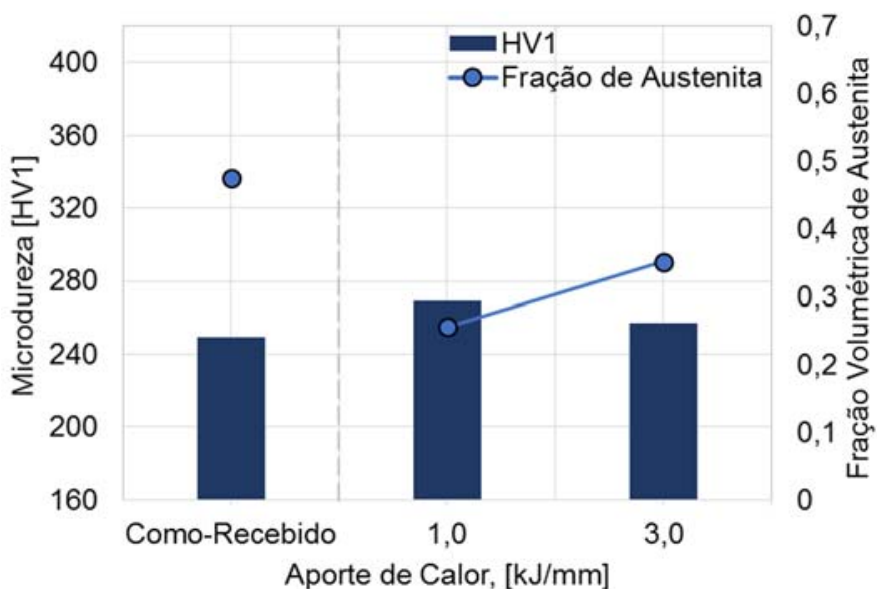

Figura 6-15. Relação entre microdureza [HV1], fração volumétrica de austenita e aporte de calor no aço inoxidável duplex UNS S32205.

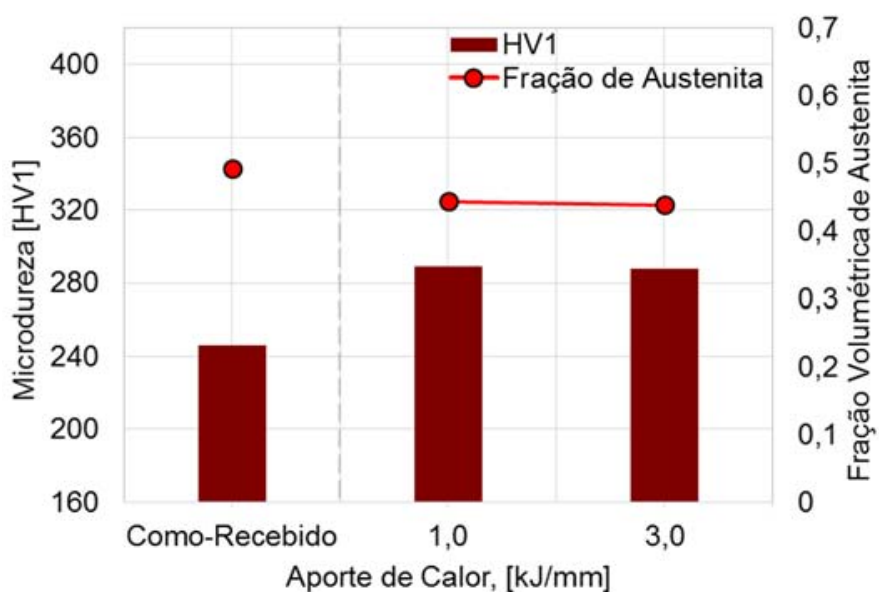

Figura 6-16. Relação entre microdureza [HV1], fração volumétrica de austenita e aporte de calor no aço inoxidável super duplex UNS S32750. 
A microdureza HV0.01 das fases austenita e ferrita para os três aços em estudo estão dentro do esperado. Para o lean duplex a microdureza das fases austenita e ferrita são as menores quando comparadas com a microdureza da austenita e da ferrita dos aços duplex e super duplex.

Os valores da microdureza das fases ferrítica e austenítica nas ZTAs simuladas são uma função do aporte de calor (e além do tempo de resfriamento $\Delta t_{12 / 8)}$ e são apresentados para o aço lean duplex, duplex e super duplex nas Figuras 6-17, 6-18 e 6-19 respectivamente. Nessas figuras se apresenta separadamente a microdureza da austenita (Widmanstätten e intergranular) e da ferrita (matriz ferrítica perto dos contornos de grão e região central dos grãos onde se encontram os precipitados de $\mathrm{Cr}_{2} \mathrm{~N}$ ).

Observa-se que os maiores valores de dureza nos grãos de ferrita se localizam na região central, onde previamente foram observados os precipitados de $\mathrm{Cr}_{2} \mathrm{~N}{ }^{59}$, quando comparada a região próxima das interfaces austenita / ferrita, esse comportamento é o mesmo nas ZTAs dos três aços em estudo.

No aço lean duplex, o incremento na microdureza entre estas duas regiões da ferrita foi de $8,7 \%$ na ZTA simulada com $1,0 \mathrm{~kJ} / \mathrm{mm}$ y de $14,1 \%$ na ZTA simulada com 3,0 kJ/mm (Figura 6-17 (a)). No aço duplex esse aumento na microdureza dos grãos de ferrita foi de 10,7\% para as duas ZTAs simuladas com 1,0 e $3,0 \mathrm{~kJ} / \mathrm{mm}$ (Figura 6-18 (b)), e finalmente no aço super duplex, esse incremento na microdureza da ferrita foi de $13,0 \%$ e $3,5 \%$ na ZTA simulada com 1,0 e de 3,0 kJ/mm (Figura 6-19 (a)). A precipitação do nitreto de cromo empobrece em cromo a matriz ferrítica e por essa ração o valor da microdureza diminui.

Para todas as ZTAs simuladas foi observado que a austenita Widmanstätten foi a fase mais dura como se esperava devido à composição química, isso foi observado em todas as ZTAs simuladas como mostrado nas Figuras 6-17 (b), 618 (b) e 6-19 (b).

Para os aços lean duplex e duplex, as microdurezas das fases presentes nas ZTAs simuladas com alto aporte de calor $\left(3,0 \mathrm{~kJ} / \mathrm{mm}\right.$ e têmpera a $\left.250^{\circ} \mathrm{C}\right)$ foram a mais duras, e além foram essas amostras as que apresentaram uma matriz ferrítica mais homogênea. Isso pode indicar que nessa condição de simulação da ZTA, os elementos podem ser dissolvidos mais facilmente porque a tempos de resfriamento $\Delta t_{12 / 8}$ e $\Delta t_{8 / 5}$ são maiores como mostrado nas Figuras 6-17 e 6-18. 
(a)

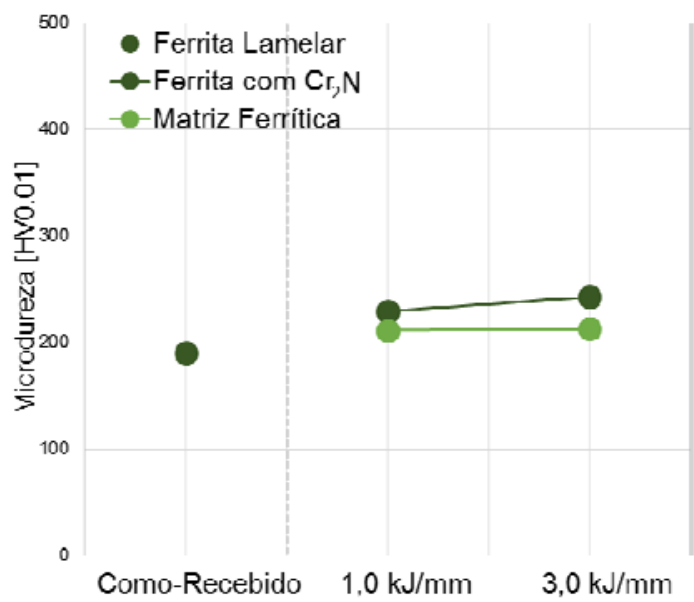

(b)

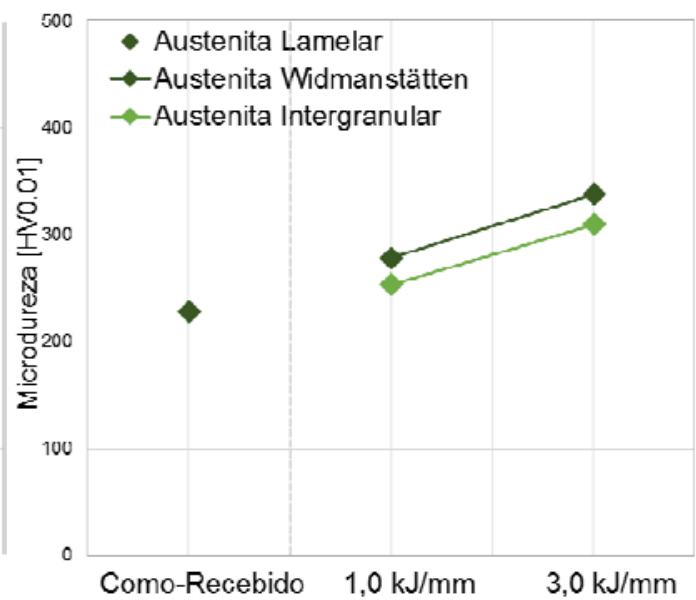

Figura 6-17. Microdurezas das fases austenítica e ferrítica no aço lean duplex UNS S32304.

(a)

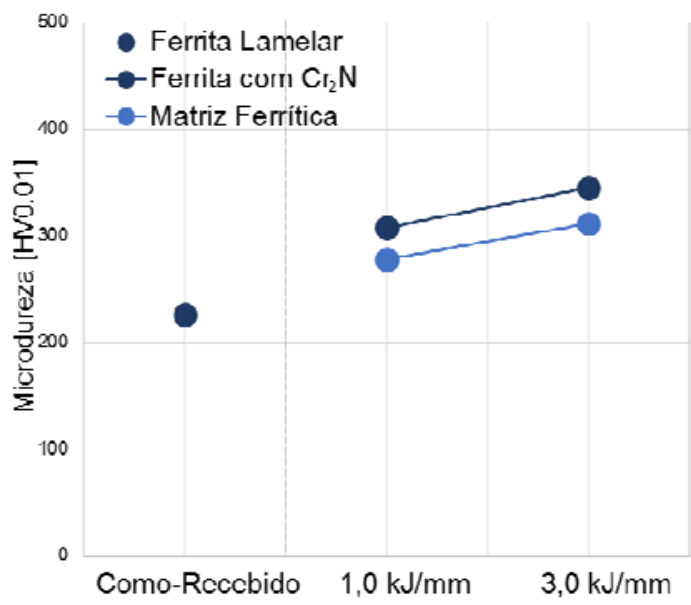

(b)

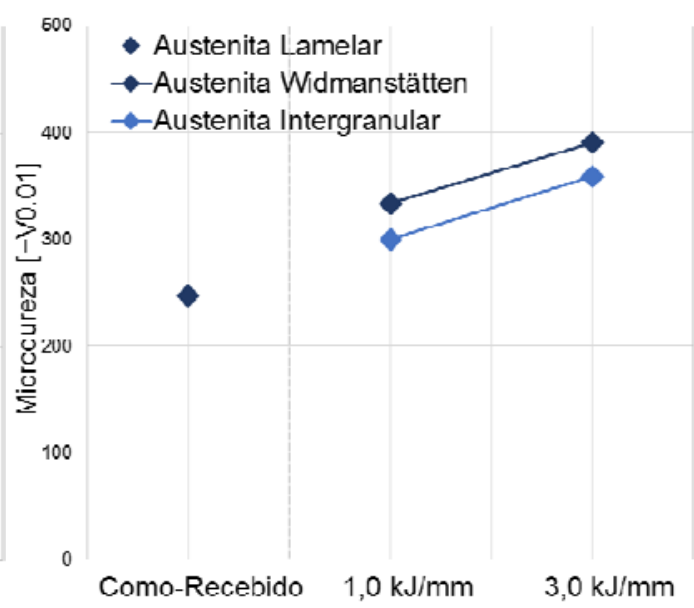

Figura 6-18. Microdurezas das fases austenítica e ferrítica no aço duplex UNS S32205.

(a)

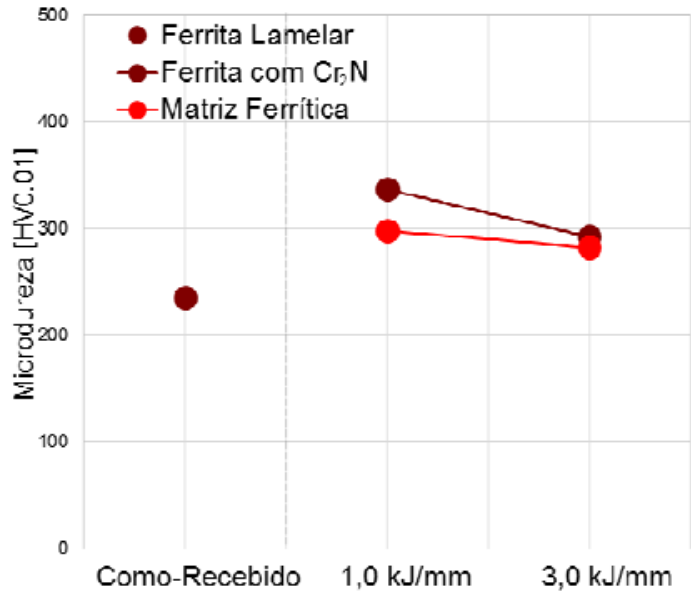

(b)

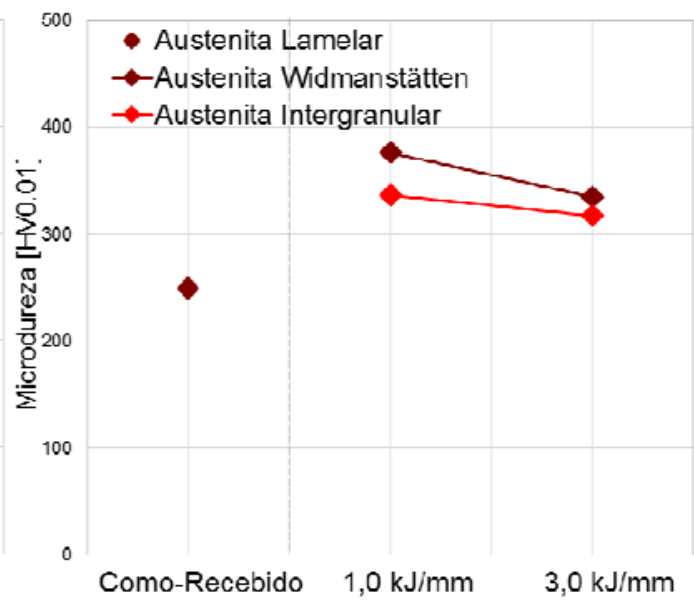

Figura 6-19. Microdurezas das fases austenítica e ferrítica no aço super duplex UNS S32750. 


\section{7 \\ Conclusões}

O presente trabalho objetivou simular a ZTA de alto e baixo aporte de calor em diferentes aços inoxidáveis duplex, utilizando a Gleeble de modo a avaliar a evolução microestrutural que ocorre em função dos diferentes aportes de calor (e taxas de resfriamento). Estes dados serão úteis na determinação de especificação de soldagem destes aços permitindo definir quais aportes serão mais sensíveis a formação de fases indesejáveis. Para as condições estudadas pode-se concluir o seguinte:

1. Durante a simulação da soldagem o alto teor de nitrogênio promoveu a estabilização da austenita na ZTA no aço inoxidável duplex UNS S32205. Além disso nos três aços, o nitrogênio saturado na ferrita favoreceu a precipitação das fases de $\mathrm{Cr}_{2} \mathrm{~N}$ na região central dos grãos de ferrita e de $\mathrm{CrN}$ nas interfaces de austenita / ferrita. O aço inoxidável lean duplex UNS S32304 apresenta um teor de cromo ligeiramente elevado, sendo o cromo um estabilizador da ferrita e também formador de nitretos $\left(\mathrm{Cr}_{2} \mathrm{~N}\right.$ e $\left.\mathrm{CrN}\right)$ que favorece a tendência de promover a precipitação dessas fases.

2. Os diagramas das frações de fases molares em função da temperatura dos três aços estudados obtidos no software Thermo-Calc, em geral apresentam um comportamento similar durante o resfriamento:

- A faixa de temperatura de ferritização completa para os três aços foi entre 1352 e $1329^{\circ} \mathrm{C}$, depois disso a ferrita se transforma progressivamente em austenita. $\mathrm{Na}$ faixa de temperatura de $1275-989^{\circ} \mathrm{C}$ as duas fases primarias: ferrita e austenita estão em uma relação aproximada de 50:50.

- O início da formação da fase $\sigma$ ocorre com a solubilização parcial da ferrita que se transforma em fase $\sigma$ e austenita secundária. Com a redução progressiva da temperatura a austenita se transforma parcialmente em ferrita, permanecendo a fase $\sigma$ sem modificações até dissolver-se por completo nos três aços estudados aproximadamente a $400^{\circ} \mathrm{C}$. 
- A temperaturas inferiores a $400^{\circ} \mathrm{C}$, a microestrutura é basicamente ferrita com frações baixas das fases de nitretos e carbonetos (frações menores de 0,1 ), além das fases intermetálicas como a fases $M u, P$ e $\pi$.

3. Foram identificadas diferenças importantes em cada um dos diagramas de fases dos três AIDs obtidos no software Thermo-Calc:

- A temperatura máxima da formação da fase $\sigma$ aumenta do aço lean duplex, o duplex e o super duplex nesta ordem, no aço lean duplex essa temperatura de início de formação de fase $\sigma$ é de $776^{\circ} \mathrm{C}$, para o aço duplex de $874^{\circ} \mathrm{C}$ e para o aço super duplex de $993^{\circ} \mathrm{C}$. Sendo o aço super duplex o aço com a fração molar da fase $\sigma$ mais alta com 0,354 . Além os teores de níquel e manganês também são os maiores neste grau de aço, e o níquel acelera a cinética de precipitação da fase $\sigma^{1756}$. Durante o resfriamento a fase $\sigma$ se forma primeiro e em maior quantidade no aço inoxidável super duplex.

- A formação da fase $\chi$ (composto ternário $\mathrm{Fe}, \mathrm{Cr}$ e Mo) é prevista só para os aços duplex e super duplex, que são os graus de aço com maior teor de molibdênio. A faixa de temperatura na qual aparece a fase $\chi$ nestes dois graus de aços vai de 923 até $517^{\circ} \mathrm{C}$ para o aços duplex e de 790 até $524^{\circ} \mathrm{C}$ para o aços super duplex. A máxima fração molar da fase $\chi$ no aço super duplex foi 0,128 , que é precisamente o grau do aço que possui o maior teor de molibdênio e cromo.

- Os nitretos $\mathrm{Cr}_{2} \mathrm{~N}$ estão nos três aços em estudo, mais o teor no aço duplex é superior, alcançou uma fração molar máxima de 0,048 a $1098^{\circ} \mathrm{C}$, isso devido ao alto teor de nitrogênio neste grau de aço. O aço duplex prevê que o $\mathrm{Cr}_{2} \mathrm{~N}$ se formar primeiro e em maior quantidade no aço inoxidável duplex.

4. Os elementos mais importantes nos AIDs em estudo são cromo, níquel, molibdênio e manganês. Estes 4 elementos estão presentes no aço inoxidável super duplex com os maiores teores. O efeito destes elementos nos diagramas de fases simulados no software Thermo-Calc pode ser simplificado assim:

- Cromo e Molibdênio, são elementos estabilizadores da austenita, e promovem a formação da fase $\chi$ e da fase $\sigma$. A previsão destas fases é maior nos aços super duplex que têm os maiores teores nesses dois elementos. $\mathrm{O}$ cromo também se encontra nos precipitados de $\mathrm{Cr}_{2} \mathrm{~N}$, neste caso o teor de nitrogênio foi um fator determinante, e fez que a previsão de 
maior fração de precipitados de $\mathrm{Cr}_{2} \mathrm{~N}$ no aço duplex que tem o maior teor de nitrogênio.

- Níquel e Manganês, estes dois elementos são estabilizadores da fase ferrítica, o maior teor destes elementos se encontra no aço super duplex e estão relacionados como a previsão de maior quantidade de fase $\sigma$, (composto ternário de $\mathrm{Fe}, \mathrm{Cr}$ e Mo com baixo teor de níquel e manganês) ${ }^{56}$ e além que o níquel acelera a cinética de precipitação da fase $\sigma^{1756}$.

5. A microestrutura formada na ZTA no aços lean duplex corresponde a austenita lamelar que foi dissolvida completamente e grãos de ferrita grandes com uma quantidade limitada de austenita reformada durante o resfriamento. No aço duplex a microestrutura da ZTA corresponde à austenita lamelar que foi dissolvida completamente e grãos de ferrita com uma grande quantidade de austenita reformada durante o resfriamento.

No caso da microestrutura da ZTA simulada no aço super duplex, corresponde à austenita parcialmente transformada rodeada de grãos de ferrita que cresceram de maneira limitada. Embora durante as simulações a temperatura de pico tenha sido alcançada como programado, e que além essa temperatura foi superada pelo overshooting com uma média para este grau de aço de 9,6 s, a austenita lamelar não foi dissolvida completamente. Se identificou a direção de laminação do processo de fabricação do tubo de aço super duplex nas ZTAs simuladas o que indica que a austenita não foi dissolvida completamente só para este grau de aço, e não por causa da temperatura de pico mais pelo tempo mantido nessa temperatura durante as simulações. O ângulo de Feret dos grãos de austenita foi medido em todas as micrografias das ZTAs simuladas no aço inoxidável super duplex como mostrado na Tabela 6-6, com uma média de 17 graus medido desde a horizontal.

6. A evolução microestrutural das fases primárias durante o aumento do aporte de calor nas simulações das ZTAs para o aço lean duplex mostra que a ferrita apresentou uma leve redução nas frações volumétricas de fases variando entre 0,817 e 0,780 quando o aporte de calor aumenta de 1,5 a 3,0 kJ/mm com têmpera em água a $500^{\circ} \mathrm{C}$, e de 0,816 até 0,756 de ferrita quando o aporte aumenta de 1,0 até $3,0 \mathrm{~kJ} / \mathrm{mm}$ com têmpera a $250^{\circ} \mathrm{C}$ (Figura $5-16$ ). Em todas as condições de simulação da ZTA no aço lean duplex a fração volumétrica da ferrita foi alta em relação ao balanço de fases 50:50 dos IADs e em relação à fração 
volumétrica da ferrita do aço na condição de como-recebido $(0,593)$. E isso afetou o comportamento mecânico e de microdureza neste grau de aço.

Por outro lado, as ZTAs simuladas nos aços duplex e super duplex mantiveram um balanço de fases mais perto do 50:50 especialmente o aço super duplex.

7. A maior fração volumétrica de ferrita nas ZTAs simuladas no aço lean duplex é devido ao fato que durante a simulação das ZTAs o tempo na temperatura de pico foi suficiente para atingir a ferritização completa, isto é corroborado pelo tamanho de grão de ferrita maior do que os outros dois aços avaliados. Este foi o comportamento oposto ao acontecido durante a simulação das ZTAs no aço super duplex, onde o tempo de $2 \mathrm{~s}$ na temperatura de pico não foi suficiente para dissolver a austenita lamelar toda presente no aço na condição de como-recebido.

8. Foram observados precipitados de $\mathrm{Cr}_{2} \mathrm{~N}$ localizados preferencialmente na região central dos grãos de ferrita nas ZTAs simuladas com baixo aporte de calor $(1,0 \mathrm{~kJ} / \mathrm{mm})$ onde a taxa de resfriamento foi a mais rápida $\left(\Delta t_{12 / 8}\right.$ de $\left.6,7 \mathrm{~s}\right)$ não permitindo que o cromo e o nitrogênio sejam dissolvidos na ferrita, permanecendo preferivelmente como precipitado. Essa precipitação empobrece a matriz ferrita nesses dois elementos e consequentemente faz que a microdureza seja reduzida. O nitreto $\mathrm{CrN}$ tende a precipitar nas interfaces ferrita / austenita em paralelo ao à precipitação do nitreto $\mathrm{Cr}_{2} \mathrm{~N}$ especialmente com as taxas de resfriamento altas.

9. O tamanho de grão da ferrita e da austenita nas ZTAs foi afetado pelo aporte de calor, ou seja, quanto maior foi o aporte de calor, maior foi o tamanho de grão. Isso ocorre como consequência do incremento dos tempos $\Delta t_{12 / 8}$ e $\Delta t_{8 / 5}$ que favorecem ao crescimento dos grãos. Deste modo, para as simulações das ZTAs do primeiro grupo de corpos de prova (têmpera em água a $500^{\circ} \mathrm{C}$ ) com aporte de calor alto $(3,0 \mathrm{~kJ} / \mathrm{mm})$, os tempos $\Delta t_{12 / 8}$ e $\Delta t_{8 / 5}$ são 4 vezes maiores do que os tempos $\Delta t_{12 / 8}$ e $\Delta t_{8 / 5}$ correspondentes às simulações das ZTAs com aporte de calor baixo $(1,5 \mathrm{~kJ} / \mathrm{mm})$ para uma chapa de $10 \mathrm{~mm}$ de espessura. No segundo grupo de corpos de prova (têmpera a $250^{\circ} \mathrm{C}$ ) os tempos $\Delta t_{12 / 8}$ e $\Delta t_{8 / 5}$ dos aportes de $3,0 \mathrm{~kJ} / \mathrm{mm}$ são 9 vezes maiores do que os tempos $\Delta t_{12 / 8}$ e $\Delta t_{8 / 5}$ dos aportes de 1,0 kJ/mm para uma chapa de $10 \mathrm{~mm}$ de espessura. 
10. A taxa de resfriamento é o fator dominante para o crescimento dos grãos de ferrita. As taxas de resfriamento mais lentas $\left(\Delta t_{12 / 8}\right.$ de $60,2 \mathrm{~s}$ e aporte de calor de $3,0 \mathrm{~kJ} / \mathrm{mm}$ ) depois de permanecer na temperatura de pico de $1350^{\circ} \mathrm{C}$ por 2 segundos, contribuem para obter o maior tamanho de grão da ferrita nas HAZs simuladas. Com um $\Delta t_{12 / 8}$ de $60,2 \mathrm{~s}$ o tamanho do grão de ferrita obtido nos três aços estudados são os maiores em todas as condições de simulação da ZTA, da mesma maneira com $\Delta t_{12 / 8}$ de $6,7 \mathrm{~s}$ que foi o menor tempo programado o tamanho da ferrita é o menor obtido em todas as condições de simulação da ZTA.

O crescimento do grão da ferrita é muito mais susceptível do aporte de calor (consequentemente aos tempos $\Delta t_{12 / 8}$ e $\Delta t_{8 / 5}$ e às taxas de resfriamento) no aço inoxidável lean duplex, sendo o menos susceptível o aço inoxidável super duplex.

11. O aço super duplex foi o aço que apresentou maior fração volumétrica de austenita quando comparado em qualquer condição de simulação da ZTA com os outros dois aços. Como os parâmetros de simulação das ZTAs foram os mesmas para os três aços, esse comportamento de alta fração volumétrica de austenita no aço super duplex é devido ao tempo de permanência na temperatura de pico de $2 \mathrm{~s}$, o qual não foi suficiente para a dissolução da austenita e atingir ferritização completa durante as simulações de ZTA.

12. A fração volumétrica da austenita nas ZTAs simuladas é uma função dos tempos $\Delta t_{12 / 8}$ e $\Delta t_{8 / 5}$. Com um tempo de $\Delta t_{12 / 8}$ de $60,2 \mathrm{~s}$ (o maior tempo $\Delta t_{12 / 8}$ programado para as simulações das ZTAs) foram obtidas as maiores frações de austenita em cada um dos três aços em estudo, da mesma maneira com o tempo $\Delta t_{12 / 8}$ de $6,7 \mathrm{~s}$ que foi o menor tempo programado as menores frações de austenita foram obtidas nos três aços.

O aumento progressivo da fração volumétrica da fase austenítica quando o tempo $\Delta t_{12 / 8}$ é incrementado é evidenciado no aumento da espessura dos grãos de austenita. As agulhas de austenita Widmanstätten vão-se tornando mais espessas e os grãos de austenita intergranular também exibem um crescimento proporcional ao tempo de resfriamento $\Delta t_{12 / 8}$ e ao aporte de calor.

13. De um modo geral o limite de escoamento das ZTAs simuladas no aço lean duplex diminuiu em $22,2 \%$ quando comparado com o aço na condição comorecebido, seguido do limite de resistência que reduziu em 27,5\%. Esse comportamento está associado à diminuição em $49,1 \%$ da fração volumétrica de 
austenita na microestrutura (mudou de austenita lamelar e intragranular na condição de como-recebido a austenita Widmanstätten, intragranular e intergranular nas ZTAs simuladas). Além disso, esses valores estão associados aos tempos de resfriamento $\Delta t_{12 / 8}$ durante a simulações das ZTAs e além ao efeito dos elementos estabilizadores de ferrita como de cromo e molibdênio que estão em menor teor neste grau de aço. No entanto, que o limite de escoamento e o limite de resistência das ZTAs simuladas nos aços duplex e super duplex se mantiveram na mesma faixa da condição de como-recebido.

14. Como esperado, o aço inoxidável super duplex apresenta o maior limite de escoamento e o maior limite de resistência quando comparado com os outros dois AIDs como corresponde à maior fração volumétrica de austenita na microestrutura dos três aços em estudo tanto na condição de como-recebido quanto nas ZTAs simuladas.

15. Os valores da microdureza das fases ferrítica e austenítica nas ZTAs simuladas são uma função do aporte de calor (e além do tempo de resfriamento $\left.\Delta t_{12 / 8}\right)$. Nos grãos de ferrita, os valores maiores de dureza foram identificados na região central dos grãos, onde foram observados os precipitados de $\mathrm{Cr}_{2} \mathrm{~N}$ em comparação com a matriz ferrítica perto das interfaces ferrita / austenita. A precipitação do $\mathrm{Cr}_{2} \mathrm{~N}$ empobrece em cobre a matriz ferrítica e por essa ração o valor da microdureza diminui. Essa precipitação de $\mathrm{Cr}_{2} \mathrm{~N}$ se apresenta em maior proporção nas simulações com baixo aporte de calor (tempos curtos de resfriamento). Como se esperava, para todas as ZTAs simuladas foi observado que a austenita Widmanstätten foi a fase mais dura devido à sua composição química.

Para os três aços em estudo, as microdurezas das fases presentes nas ZTAs simuladas com alto aporte de calor $\left(3,0 \mathrm{~kJ} / \mathrm{mm}\right.$ e têmpera a $\left.250^{\circ} \mathrm{C}\right)$ foram a mais duras, apresentando uma matriz ferrítica mais homogênea. Isso pode indicar que nessa condição de simulação da ZTA, os elementos podem ser dissolvidos mais facilmente porque a tempos de resfriamento é mais $\Delta t_{12 / 8}$ e $\Delta t_{8 / 5}$ são maiores. 


\section{1.}

Sugestões para Trabalhos Futuros

- Identificar as fases secundarias como $\sigma$ e $X$ (com diferentes ataques, como $\mathrm{NaOH}$ e ácido acético) com elétrons retroespalhados.

- Verificar a presença de Nitretos, e as fases $\sigma$ e $\chi$ via MET.

- Quantificar as frações volumétricas das fases secundarias como Nitretos, $\sigma$ $\mathrm{e} \chi$.

- Conferir a composição química das fases presentes para entender a difusão de elementos como cromo e molibdênio.

- Estudar o efeito dos aportes de calor e das taxas de resfriamento na resistência à corrosão. 
8

\section{Referências bibliográficas}

1 ATAMERT, S.; KING, J. E. Super duplex stainless steels. Part 1 Heat affected zone microstructures. Materials Science and Technology, v. 8, n. 10, p. 896-911, 1992.

$2 \quad$ KARLSSON, L. Welding Duplex Stainless Steels - A Review of Current Recommendations. Welding in the World, v. 56, n. 5-6, p. 65-76, 2012.

3 MISHRA, M. K. et al. Effect of preaging Deformation on Aging Characteristics of 2507 Super Duplex Stainless Steel. Journal of Materials Engineering and Performance, v. 25, n. 2, p. 374-381, 2016.

KROLCZYK, G.; NIESLONY, P.; LEGUTKO, S. Microhardness and Surface Integrity in Turning Process of Duplex Stainless Steel (DSS) for Different Cutting Conditions. Journal of Materials Engineering and Performance, v. 23, n. 3, p. 859-866, 2014.

CASTAÑEDA, E. et al. Lases Shock Processing with Different Conditions of Treatment on Duplex Stainless Steel. Journal of Materials Engineering and Performance, v. 24, n. 6, p. 2521-2525, 2015.

EZUBER, H. M.; EL-HOUD, A.; EL-SHAWESH, F. Effects of sigma phase precipitation on seawater pitting of duplex stainless steel. Desalination, 2007.

CALUSCIO DOS SANTOS, D.; MAGNABOSCO, R. Kinetic Study of Predict Sigma Phase Formation in Duplex Stainless Steels. Metallurgical and Materials Transactions A, v. 47A, n. April, p. 1554-1565, 2016.

MITELA, I. et al. Cavitation Erosion of Sensitized UNS S31803 Duplex Stainless Steels. 2016.

NEISSI, R.; SHAMANIAN, M.; HAJIHASHEMI, M. The Effect of Constant and Pulsed Current Gas Tungsten Arc Welding on Joint Properties of 2205 Duplex Stainless Steel to 316L Austenitic Stainless Steel. Journal of Materials Engineering ans Performance, v. 25, n. 5, p. 2017-2028, 2016.

WESTIN, E. M. et al. Laser Welding of a Lean Duplex Stainless Steel. 26th International Congress on Applications of Lasers and Electro-Optics, ICALEO 2007: Congress Proceedings, p. 335-344, 2007.

SIEURIN, H.; SANDSTRÖM, R. Sigma phase precipitation in duplex stainless steels 2205. Materials Science and Engineering: A, v. 444, n. 1-2, p. 271-276, 2007. in the Unified Numbering System (UNS) 2016. 
ASM. Volume 1, Properties and Selection: Irons, Steels, and High Performance Alloys, 2005.

DAVISON, R. M.; REDMOND, J. D. A guide to using duplex stainless steels. Materials and Design, v. 12, n. 4, p. 187-192, 1991.

ALVAREZ-ARMAS, I. Duplex Stainless Steels: Brief History and Some Recent Alloys. Recent Patents on Mechanical Engineering, v. 1, n. 1, p. 51-57, 2008.

CHIU, L. H.; HSIEH, W. C.; LING, Y. C. Effect of vacuum brazing on corrosion resistance of UNS S31803 and UNS S31200 duplex stainless steels. Corrosion, v. 58, n. 9, p. 797-803, 2002.

NILSSON, J.-O. Overview Super Duplex Stainless-Steels. Materials Science and Technology, v. 8, n. 8, p. 685-700, 1992.

RAHMANI, M.; EGHLIMI, A.; SHAMANIAN, M. Evaluation of microstructure and mechanical properties in dissimilar austenitic/super duplex stainless steel joint. Journal of Materials Engineering and Performance, v. 23, n. 10, p. 3745-3753, 2014.

EGHLIMI, A.; SHAMANIAN, M.; RAEISSI, K. Dilution and ferrite number prediction in pulsed current cladding of super-duplex stainless steel using RSM. Journal of Materials Engineering and Performance, v. 22, n. 12, p. 3657-3664, 2013.

KARLSSON, L. Welding duplex and super duplex stainless steels. AntiCorrosion Methods and Materials, v. 42, n. 6, p. 30-35, 1995.

KIM, Y.-J.; CHUMBLEY, S.; GLEESON, B. Determination of isothermal transformation diagrams for sigma-phase formation in cast duplex stainless steels CD3MN and CD3MWCuN. Metallurgical and Materials Transactions A, v. 35A, n. 11, p. 3377-3386, 2004.

HA, H.-Y. et al. Interpretation of the relation between ferrite fraction and pitting corrosion resistance of commercial 2205 duplex stainless steel. Corrosion Science, 2014.

CALLIARI, I. et al. Effect of Continuous Cooling on Secondary Phase Precipitation in the Super Duplex Stainless Steel ZERON-100. Journal of Materials Engineering and Performance, v. 22, n. 12, p. 3860-3866, 2013.

AHN, Y. S. K., J.M.; JEONG, B. H. Effect of aging treatments and microstructural evolution on corrosion resistance of tungsten substituted 2205 duplex stainless steel. Materials Science and Technology, v. 18, n. 4, p. 383-388, 2002.

HUANG, C.-S.; SHIH, C.-C. Effects of nitrogen and high temperature aging on phase $\sigma$ precipitation of duplex stainless steelEffects of nitrogen and high temperature aging on phase $\sigma$ precipitation of duplex stainless steel. Materials Science and Engineering A, v. 402, p. 66-75, 2005.

KARLSSON, L.; ARCINI, H. Low Energy Input Welding of Duplex Stainless Steels. Welding in the World, v. 56, n. 9-10, p. 41-47, Sep-Oct 2012. 
WESSMAN, S. Applications of computational thermodynamics and Kinetics on transformations in stainless steels. 2013. Engineering Materials Science, Royal Institute of Technology, Stockholm, Sweden.

ASTM. G48-11: Standard Test Methods for Pitting and Crevice Resistance os Stainless Steels and Related Alloys by Use of Ferric Chloride Solution 2011.

NILSSON, J.-O.; WILSON, A. Influence of isothermal phase transformations on toughness and pitting corrosion of super duplex stainless steel SAF 2507. Materials Science and Technology, v. 9, n. 7, p. 545-554, 1993.

STEVENS, K. J. Fatigue performance and microanalysis of heat treated 2205 duplex stainless steel. Materials Science and Technology, v. 15, n. 8, p. 903-908, 1999.

NILSSON, J.-O. et al. Mechanical Properties, Microstructural Stability and Kinetics of -Phase Formation in 29Cr-6Ni-2Mo-0.38N Superduplex Stainless Steel. Metallurgical and Materials Transactions A, v. 31A, $n$. 01, p. 35-45, 2000.

GARZÓN, C. M. et al. The relationship between atomic partitioning and corrosion resistance in the weld-heat affected zone microstructures of UNS S32304 duplex stainless steel. Journal of Materials Science, v. 42, p. 9021-9029, 2007.

ROSSO, M.; PETER, I.; SUANI, D. About Heat Treatment and Properties of Duplex Stainless Steels. Journal of Achievements in Materials and Manufacturing Engineering, v. 59, n. 1, p. 26-36, 2013.

HÄMÄLÄINEN, E. et al. Mechanical properties of powder metallurgy duplex stainless steels. Materials Science and Technology, v. 13, n. 02, p. 103-109, 1997.

ORNATO, D. High density sintering of duplex stainless steels. Powder Metallurgy, v. 45, n. 4, p. 290-293, 2002.

RAMÍREZ, A. J.; LIPPOLD, J. C.; BRANDI, S. D. The Relationship between Chromium Nitride and Secondary Austenite Precipitation in Duplex Stainless Steels. Metallurgical and Materials Transactions A, v. 34A, n. 8, p. 1575-1597, 2003.

IMOA. Practical Guideline for the Fabrication of Duplex Stainless Steel 2009.

WALKER, R. A. Duplex and high alloy stainless steels - corrosion resistance and weldability. Materials Science and Technology, v. 4, n. January, p. 78-84, 1988.

LIOU, H.-Y.; HSIEH, R.-I.; TSAI, W.-T. Microstructure and stress corrosion cracking in simulated heat-affected zones of zones stainless steels. Corrosion Science, v. 44, n. 2841-2856, 2002. 
MOURAD, A.-H. I.; KHOURSHID, A.; SHAREF, T. Gas tungsten arc laser beam welding process effects on duplex stainless steel 2205 properties. Materials Science and Engineering A, v. 549, p. 105-113, 2012.

UDAYAKUMAR, T. et al. Experimental investigation on mechanical and metallurgical properties of super duplex stainless steel joints using friction welding process. Journal of Manufacturing Processes, v. 15, p. 558-571, 2013.

PARK, H. J.; LEE, H. W. Study on cracking characteristics on aging of super duplex stainless steel weld metal. Materials Science and Technology, v. 30, n. 3, p. 377-384, 2014.

JIANG, Y. et al. Influence of $\mathrm{Cr}_{\mathrm{eq}} / \mathrm{Ni}_{\mathrm{eq}}$ on pitting corrosion resistance and mechanical properties of UNS S2304 duplex stainless steel welded jointsInfluence of Creq/Nieq on pitting corrosion resistance and mechanical properties of UNS S2304 duplex stainless steel welded joints. Corrosion Science, v. 70, p. 252-259, 2013.

SATHIYA, P. et al. Effect of shielding gases on mechanical and metallurgical properties of duplex stainless-steel welds. Journal of Materials Science, v. 44, p. 114-121, 2009.

KOTECKI, D. J.; SIEWERT, T. A. WRC-1992 Constitution Diagram for Stainless Steel Metals: A Modification of the WRC-1988 Diagram. Welding Research Suplement, p. 171-178, 1992.

ROKANOPOULOU, A.; PAPADIMITRIOU, D. Production of high nitrogen surfaces on 2205 duplex stainless steel substrate using the PTA. Materials Science and Technology, v. 27, n. 9, p. 1391-1398, 2011.

TAN, $\mathrm{H}$. et al. Influence of welding thermal cycles on microstructure and pitting corrosion resistance of 2304 duplex stainless steels. Corrosion Science, v. 55, p. 368-377, 2012.

ELMER, J. W.; PALMER, T. A.; SPECHT, E. D. In situ observations of sigma phase dissolution in 2205 duplex stainless steel using synchrotron $X$-ray diffraction. Materials Science and Engineering a-Structural Materials Properties Microstructure and Processing, v. 459, n. 1-2, p. 151-155, Jun 2007.

LI, X.; MIODOWNIK, P.; SAUNDERS, N. Modeling of materials properties in duplex stainless steels. Materials Science and Technology, v. 18, n. 08, p. 861-868, 2002.

CALLIARI, I. et al. The phase stability in $\mathrm{Cr}-\mathrm{Ni}$ and $\mathrm{Cr}-\mathrm{Mn}$ duplex stainless steels. Journal of Materials Science, v. 46, p. 6916-6924, 2011.

KOVACH, C. W. High-Performance Stainless Steels. Parr Instrument Company. 2011

COMPANY, P. I. High-Performance Stainless Steels. 2011.

ALVAREZ-ARMAS, I.; DEGALLAIX-MOREUIL, S. Duplex Stainless Steels. 2009. 437 ISBN 978-1-84821-137-7. 
LLORCA-ISERN, N. et al. Identification of Sigma and Chi Phases in Duplex Stainless Steels. Materials Characterization, v. 112, p. 20-29, 2016.

ELMER, J. W.; PALMER, T. A.; SPECHT, E. D. Direct Observations of Sigma Phase Formation in Duplex Stainless Steels Using In-Situ Synchrontron X-Ray Diffraction. Metallurgical and Materials Transactions A, v. 38A, n. 3, p. 464-475, 2007.

WESTIN, E. M. Microstructure and properties of welds in lean duplex stainless steel LDX 2101. 2010. 72 Department of Materials Science and Engineering, Royal Institute of Technology, Stockholm, Sweden.

CALLIARI, I.; ZANESCO, M.; RAMOUS, E. Influence of isothermal aging on secundary phases precipitation and toughness of a duplex stainless steel SAF 2205. Journal Materials Science, v. 41, p. 7643-7649, 2006.

CHEN, T. H.; YANG, J. R. Effects of solution and continuous on $\sigma$-phase precipitation in a 2205 duplex stainless steel. Materials Science and Engineering A, v. 311, p. 28-41, 2001.

YANG, Y. et al. The effect of large heat input on the microstructure and corrosion behaviour of simulated heat affected zone in 2205 duplex stainless steel. Corrosion Science, v. 53, p. 3756-3763, 2011.

JAE-HWAN, K. et al. Effect of Aging Treatment on Impact Toughness and Corrosion Resistance of Super Duplex Stainless Steel. Journal of Materials Engineering and Performance, v. 25, n. 1, p. 9-14, 2016.

YOGANANDH, J.; NATARAJAN, S.; KUMARESH BABU, S. P. Erosivre Wear Behavior of High-Alloy Cast Iron and Duplex Stainless Steel under Mining Conditions. Journal of Materials Engineering and Performance, v. 24, n. 9, p. 3588-3598, 2015.

MANDZIEJ, S. T. Physical Simulation of Metallurgical Processes. Materials and Technology, v. 44, n. 3, p. 105-119, 2010.

BRADASKJA, B. A laboratory test for simulation of solidification on Gleeble 1500D thermo-mechanical simulator. RMZ - Materials and Geoenvironment, v. 55, n. 1, p. 31-40, 2008.

FORREST, D. R.; SINFIELD, M. T. Numerical Simulation of Gleeble Torsion Testing of HSLA-65 Steel. 2008

RAMÍREZ LONDOÑO, A. J. Precipitação de fases intermetálicas e austenita secundária na zac de soldagens multipasse de aços inoxidáveis duplex. 2001. 265 (Doutor em Engenharia). Engenharia Metalúrgica e de Materiais, Escola Politécnica da Universidade de São Paulo, São Paulo, Brasil.

KURODA, T.; IKEUCHI, K.; KITAGAWA, Y. Role of austenite in weld toughness of super duplex stainless steel. Welding in the World, v. 49, n. 5/6, p. 29-33, 2005.

GARZÓN, C. M.; RAMÍREZ, A. J. Growth kinetics of secundary austenite in the welding microstructure of a UNS S32304 duplex stainless steel. Acta Materialia, v. 54, p. 3321-3331, 2006. 
ASTM. A790/A790M-16a: Standard Specification for Seamless and Ferritic/Austenitic Stainless Steel Pipe 2016.

A240/A240M-15b: Chromium and Chromium-Nickel Stainless Steel Plate, Sheet, and Strip for Pressure Vessels and for General Applications 2015.

A751-11: Test Methods, Practices and Terminology for Chemical Analysis of Steel Products 2011.

SOFTWARE, T.-C. TCFE3, TCS Steels/Fe-Alloys Database, version 3 2002. Information 2017.

INC., D. D. S. QuikSim ${ }^{\mathrm{TM}}$ Software Heat Affected Zone Programming Manual: Heat Affected (HAZ) ProgrammingQuikSimTM Software Heat Affected Zone Programming Manual: Heat Affected (HAZ) Programming 2001.

QuikSim2 User's Guide. Release 2.4.51812013.

SANDVIK. Sandvik SAF 2304 (Tube and pipe, seamless). 2015. Disponível em: < www.smt.sandvik.com/en/materials-center/materialdatasheets/tube-and-pipe-seamless/sandvik-saf-2304/?pdf=1 > . Sandvik SAF 2205 (Tube and pipe, seamless). 2015. Disponível em: < www.smt.sandvik.com/en/materials-center/materialdatasheets/tube-and-pipe-seamless/sandvik-saf-2205/?pdf=1 >.

CALLIARI, I.; STRAFFELINI, G.; RAMOUS, E. Investigation of secundary phase effect on 2205 DSS fracture toughness. Materials Science and Technology, v. 26, n. 1, p. 81-86, 2010. 
LI, Z. J. et al. Effect of melt superheat on structure of unsteady state unidirecrionally solidified duplex stainless steel. Materials Science and Technology, v. 27, n. 4, p. 818-822, 2011.

SAEID, T. et al. Effect of friction stir welding speed on the microstructure and mechanical properties of a duplex stainless steel. Materials Science and Engineering A, v. 496, p. 262-268, 2008.

SOYLU, B.; HONEYCOMBE, W. K. Microstructural refinement of duplex stainless steels. Materials Science and Technology, v. 7, n. 2, p. 137146, 1991.

MAGNABOSCO, R. Kinetics of Sigma Phase Formation in a Duplex Stainless Steel. Materials Research, v. 12, n. 3, p. 321-327, 2009.

BADJI, R. et al. Phase transformation and mechanical behavior in annealed 2205 duplex stainless steel welds. Materials Characterization, v. 59 , p. $447-453,2008$.

8

WENG, K. L.; CHEN, H. R.; YANG, J. R. The low-temperature aging embrittlement in a 2205 duplex stainless steel. Materials Science and Engineering A, v. 379, p. 119-132, 2003.

CHEN, T. H.; YANG, J. R. Microstructural characterization of simulated heat affceted zone in a nitrogen-containing 2205 duplex stainless steel. Materials Science and Engineering A, v. 338, p. 166-181, 2002.

GUTIÉRREZ, I. et al. Bonding by hot extrusion of Inconol 825 and Duplex 2205 to low allow steel. Materials Science and Technology, v. 7, n. 8, p. 761-769, 1991.

SANTOS, T. F. A. et al. Microestructure evaluation of UNS S32205 duplex stainless steel friction stir welds. REM: Revista Escola de Minas, Ouro Preto, v. 66, n. 2, p. 187-191, 2013.

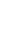

Detailed Microstructural Characterization and Restoration Mechanisms of Duplex and Superduplex Stainless Steel Friction-StirWelded Joints. Journal of Materials Engineering and Performance, v. 25, n. 12, p. 5173-5188, 2016.

LI, X. Y. et al. Low temperature plasma surface surface alloying and characterisation of a superduplex stainless steel. International Heat Treatment and Surface Engineering, v. 8, n. 2, p. 61-64, 2014.

ASTM. A370-17: Standard Test Methods and Definitions for Mechanical Testing of Steel Products 2017. Metallic Materials 2016.

CALLISTER, W. D. J.; RETHWISCH, D. G. Materials Science and Engineering an Introduction. 9th Edition. 2014. ISBN 978-1-118-324578. 
ASTM. G140-12b: Standard Hardness Conversion Tables for Metals Relationship Among Brinell Hardness, Vickers Hardness, Rockwell Hardness, Superficial Hardness, Knoop Hardness, Scleroscope Hardness and Leeb Hardness 2012.

E92-17: Standard Test Methods for Vickers Hardness and Knoop Hardness of Metallic Materials 2017. E384-16: Standard Test Method for Microindentation Hardness of Materials 2016.

OLAYA-LUENGAS, L. et al. Análise Microestrutural da ZTA Simulada na Gleeble do Aço Duplex 2205. ABM Week 2016. 71 Congresso Anual. Rio de Janeiro, RJ, Brasil: Associação Brasileira de Metalurgia, Materiales e Mineração - ABM: 956-965 p. 2016.

ASTM. E112-13: Standard Test Methods for Determining Average Grain Size 2013.

INC, D. S. Gleeble Users Training 2014. Gleeble System and Applications 2013. affected Zone of High Nitrogen Steel. The Iron and Steel Institute of Japan International, v. 42, n. 12, p. 1391-1398, 2002. 


\section{Apêndice}

\section{Análise Química}

Resultado da análise química do aço inoxidável lean duplex UNS S32304 (2304).

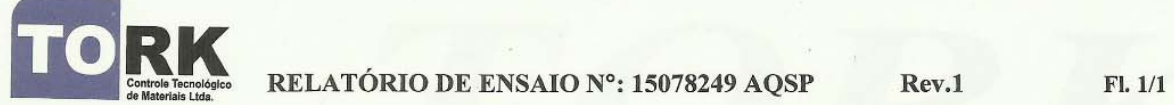

Empresa interessada : PONTIFÍCIA UNIVERSIDADE CATÓLICA DO RIO DE JANEIRO

Rua Marquês de São Vicente, $n^{\circ} 225$ - Gávea - Rio de Janeiro / RJ

Pedido de ensaio : 279286

Natureza do trabalho : ANÁLISE QUÍMICA.

Indicações fornecidas pelo interessado sobre o material ensaiado:

QUANTIDADE_ 01 Amostra para analise química

IDENTIFICAC̃̃O Lean Duplex $9,0 \mathrm{~mm}$

RESULTADOS OBTIDOS COMPOSIÇÃO QUÍMICA (\%)

$\begin{array}{lcc}\text { Carbono } & (\mathrm{C}) & 0,027 \\ \text { Silício } & (\mathrm{Si}) & 0,338 \\ \text { Manganês } & (\mathrm{Mn}) & 1,38 \\ \text { Fósforo } & (\mathrm{P}) & 0,026 \\ \text { Enxofre } & (\mathrm{S}) & 0,0042 \\ \text { Cromo } & (\mathrm{Cr}) & 23,09 \\ \text { Níquel } & (\mathrm{Ni}) & \sim 4,96 \\ \text { Molibdênio } & (\mathrm{Mo}) & 0,182 \\ \text { Aluminio } & (\mathrm{Al}) & 0,0040 \\ \text { Cobre } & (\mathrm{Cu}) & 0,433 \\ \text { Cobalto } & (\mathrm{Co}) & 0,0042 \\ \text { Titânio } & (\mathrm{Ti}) & <0,0010 \\ \text { Nióbio } & (\mathrm{Nb}) & 0,036 \\ \text { Vanádio } & (\mathrm{V}) & 0,036 \\ \text { Tungstênio } & (\mathrm{W}) & 0,013 \\ \text { Chumbo } & (\mathrm{Pb}) & <0,0030 \\ \text { Boro } & (\mathrm{B}) & 0,0016 \\ \text { Estanho } & (\mathrm{Sn}) & <0,0010 \\ \text { Arsênio } & (\mathrm{As}) & 0,0044 \\ \text { Bismuto } & (\mathrm{Bi}) & <0,0015 \\ \text { Cálcio } & (\mathrm{Ca}) & 0,0010 \\ \text { Ferro } & (\mathrm{Fe}) & 69,4 \\ \text { Nitrogênio } & (\mathrm{N}) & 0,12\end{array}$

Procedimento Tork: série P-300.

Normas de Referências: ASTM A 751, ed. 2011.

Local e Data dos Ensaios: São Paulo, 30 de Julho de 2015. Emissão do relatório: Rio de Janeiro, 04 de Agosto de 2015.

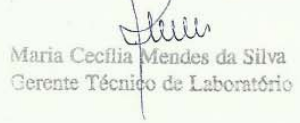

Este relatório cancela e substitui o de n 15078249 AQSP.

Os resultados apresentados no presente documento têm significicąão restrita e se aplicam somente ao objeto ensaiado ou calibrado. A sua reprodução, total ou parcial, só poderá ser

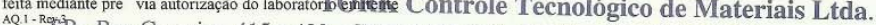

SP - Rua Cruzeiro, 415 a 423 - CEP 01137-000 - Tel./fax: (11) 3392-3902 - e-mail: tork@ laboratorios-tork.com.br

RJ - Rua Leopoldino de Oliveira, 392 - Turiaçu - CEP 21360-060 - Tel./Fax: (21) 3830-0011 - e-mail: torkrj@laboratorios-tork.com.b 
Resultado do re-teste da análise química do aço inoxidável lean duplex UNS S32304 (2304).

\section{TORK}

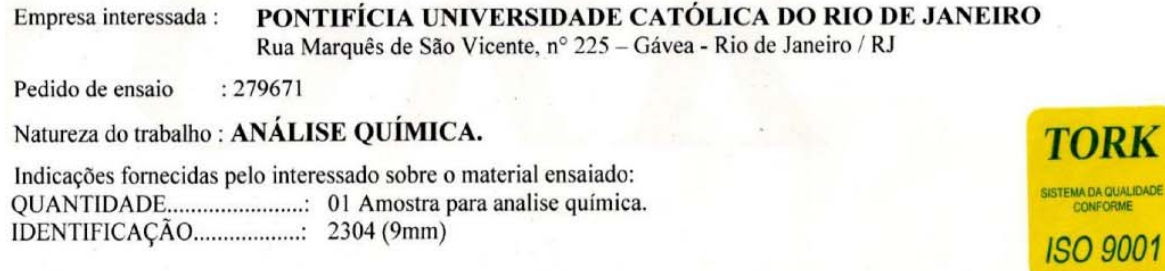

Indicações fornecidas pelo interessado sobre o material ensaiado: QUANTIDADE........................: 01 Amostra para analise química. IDENTIFICAÇÃO.....................: $2304(9 \mathrm{~mm})$

RESULTADOS OBTIDOS COMPOSIÇÃO QUIMICA (\%)

$\begin{array}{lcc}\text { Carbono } & (\mathrm{C}) & 0,028 \\ \text { Silício } & (\mathrm{Si}) & 0,398 \\ \text { Manganês } & (\mathrm{Mn}) & 1,62 \\ \text { Fósforo } & (\mathrm{P}) & 0,018 \\ \text { Enxofre } & (\mathrm{S}) & 0,0038 \\ \text { Cromo } & (\mathrm{Cr}) & 26,20 \\ \text { Niquel } & (\mathrm{Ni}) & \sim 5,02 \\ \text { Molibdênio } & (\mathrm{Mo}) & 0,179 \\ \text { Aluminio } & (\mathrm{Al}) & 0,0040 \\ \text { Cobre } & (\mathrm{Cu}) & 0,395 \\ \text { Cobalto } & (\mathrm{Co}) & 0,032 \\ \text { Titânio } & (\mathrm{Ti}) & <0,0010 \\ \text { Nióbio } & (\mathrm{Nb}) & 0,039 \\ \text { Vanádio } & (\mathrm{V}) & 0,043 \\ \text { Tungstênio } & (\mathrm{W}) & <0,010 \\ \text { Chumbo } & (\mathrm{Pb}) & 0,0030 \\ \text { Boro } & (\mathrm{B}) & 0,0018 \\ \text { Estanho } & (\mathrm{Sn}) & <0,0010 \\ \text { Arsênio } & (\mathrm{As}) & <0,0015 \\ \text { Bismuto } & (\mathrm{Bi}) & <0,0015 \\ \text { Cálcio } & (\mathrm{Ca}) & 0,0008 \\ \text { Ferro } & (\mathrm{Fe}) & 66,00 \\ \text { Nitrogênio } & (\mathrm{N}) & 0,11\end{array}$

Procedimento Tork: série P-300

Normas de Referências: ASTM A 751, ed. 2011.

Local e Data dos Ensaios: São Paulo, 24 de Setembro de 2015. Emissão do relatório: Rio de Janeiro, 25 de Setembro de 2015. 
Resultado da análise química do aço inoxidável duplex UNS S32205 (2205).

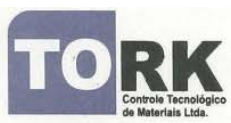

RELATÓRIO DE ENSAIO N: 15057006 AQSP

Fl. 1/1

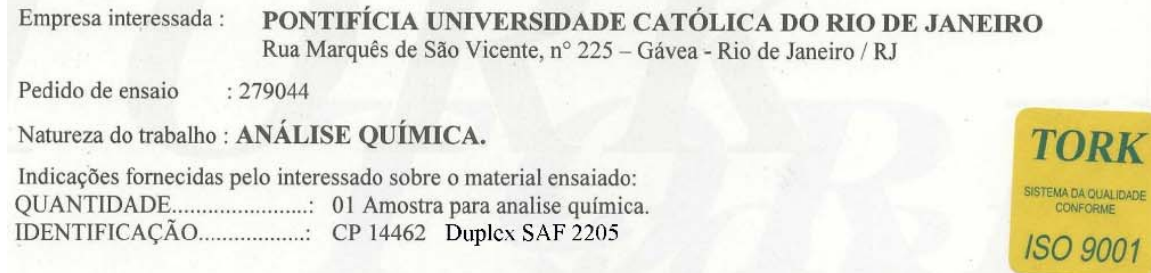

RESULTADOS OBTIDOS COMPOSIÇÃO QUÍMICA (\%)

$\begin{array}{lcc}\text { Carbono } & (\mathrm{C}) & 0,025 \\ \text { Silício } & (\mathrm{Si}) & 0,498 \\ \text { Manganês } & (\mathrm{Mn}) & 0,82 \\ \text { Fósforo } & (\mathrm{P}) & 0,027 \\ \text { Enxofre } & (\mathrm{S}) & 0,0041 \\ \text { Cromo } & (\mathrm{Cr}) & 22,48 \\ \text { Níquel } & (\mathrm{Ni}) & 5,21 \\ \text { Molibdênio } & (\mathrm{Mo}) & 3,25 \\ \text { Aluminio } & (\mathrm{Al}) & 0,0078 \\ \text { Cobre } & (\mathrm{Cu}) & 0,132 \\ \text { Cobalto } & (\mathrm{Co}) & 0,054 \\ \text { Titânio } & (\mathrm{Ti}) & <0,0010 \\ \text { Nióbio } & (\mathrm{Nb}) & <0,0040 \\ \text { Vanádio } & (\mathrm{V}) & 0,083 \\ \text { Tungstênio } & (\mathrm{W}) & 0,043 \\ \text { Chumbo } & (\mathrm{Pb}) & <0,0030 \\ \text { Boro } & (\mathrm{B}) & 0,0025 \\ \text { Estanho } & (\mathrm{Sn}) & <0,0010 \\ \text { Arsênio } & (\mathrm{As}) & 0,0100 \\ \text { Bismuto } & (\mathrm{Bi}) & <0,0015 \\ \text { Cálcio } & (\mathrm{Ca}) & 0,0034 \\ \text { Ferro } & (\mathrm{Fe}) & 67,3 \\ \text { Nitrogênio } & (\mathrm{N}) & 0,40\end{array}$

Procedimento Tork: série P-300.

Normas de Referências: ASTM A 751, ed. 2011.

Local e Data dos Ensaios: Sầo Paulo, 07 de Maio de 2015. Emissão do relatório: Rio de Janeiro, 13 de Maio de 2015.

$$
\text { Maria Cecrilia Mendes da Silva }
$$


Re-teste da análise química do aço inoxidável duplex UNS S32205 (2205).

TORK

RELATÓRIO DE ENSAIO Nº: 15099217 AQSP

Fl. $1 / 1$

Empresa interessada : PONTIFÍCIA UNIVERSIDADE CATÓLICA DO RIO DE JANEIRO

Rua Marquês de São Vicente, $n^{\circ} 225$ - Gávea - Rio de Janeiro / RJ

Pedido de ensaio $\quad: 279671$

Natureza do trabalho : ANÁLISE QUíMICA.

Indicações fornecidas pelo interessado sobre o material ensaiado:

QUANTIDADE......

01 Amostra para analise química

TORK

IDENTIFICAÇÃO. 2205

RESULTADOS OBTIDOS

COMPOSIÇÃO QUÍMICA (\%)

$\begin{array}{lcc}\text { Carbono } & (\mathrm{C}) & 0,027 \\ \text { Silício } & (\mathrm{Si}) & 0,477 \\ \text { Manganês } & (\mathrm{Mn}) & 0,88 \\ \text { Fósforo } & (\mathrm{P}) & 0,023 \\ \text { Enxofre } & (\mathrm{S}) & 0,0041 \\ \text { Cromo } & (\mathrm{Cr}) & 22,87 \\ \text { Niquel } & (\mathrm{Ni}) & 5,25 \\ \text { Molibdênio } & (\mathrm{Mo}) & 3,16 \\ \text { Aluminio } & (\mathrm{Al}) & 0,011 \\ \text { Cobre } & (\mathrm{Cu}) & 0,137 \\ \text { Cobalto } & (\mathrm{Co}) & 0,054 \\ \text { Titânio } & (\mathrm{Ti}) & <0,0010 \\ \text { Nióbio } & (\mathrm{Nb}) & 0,0088 \\ \text { Vanádio } & (\mathrm{V}) & 0,076 \\ \text { Tungstênio } & (\mathrm{W}) & 0,041 \\ \text { Chumbo } & \text { (Pb) } & <0,0030 \\ \text { Boro } & (\mathrm{B}) & 0,0027 \\ \text { Estanho } & \text { (Sn) } & <0,0010 \\ \text { Arsênio } & (\mathrm{As}) & <0,0015 \\ \text { Bismuto } & (\mathrm{Bi}) & <0,0015 \\ \text { Cálcio } & (\mathrm{Ca}) & 0,0036 \\ \text { Ferro } & (\mathrm{Fe}) & 67,0 \\ \text { Nitrogênio } & (\mathrm{N}) & 0,42\end{array}$

Procedimento Tork: série P-300.

Normas de Referências: ASTM A 751, ed. 2011

Local e Data dos Ensaios: São Paulo, 24 de Setembro de 2015.

Emissão do relatório: Rio de Janeiro, 25 de Setembro de 2015.

Maria Cecitie Mendes da Silva

Gerente Técnico de Laboratório 
Resultado da análise química do aço inoxidável super duplex UNS S32705 (2507).

\section{TORK}

Empresa interessada : PONTIFÍCIA UNIVERSIDADE CATÓLICA DO RIO DE JANEIRO

Rua Marquês de São Vicente, ${ }^{\circ} 225$ - Gávea - Rio de Janeiro / RJ

Pedido de ensaio $\quad: 279044$

Natureza do trabalho : ANÁLISE QUÍMICA.

Indicações fornecidas pelo interessado sobre o material ensaiado:

QUANTIDADE 01 Amostra para analise química

IDENTIFICAÇÃO. CP 14410 Super Duplex SAF 2507

TORK

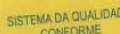

ISO 9001

RESULTADOS OBTIDOS COMPOSIÇÃO QUÍMICA (\%)

$\begin{array}{lcc}\text { Carbono } & (\mathrm{C}) & 0,022 \\ \text { Silício } & (\mathrm{Si}) & 0,300 \\ \text { Manganês } & (\mathrm{Mn}) & 0,50 \\ \text { Fósforo } & (\mathrm{P}) & 0,026 \\ \text { Enxofre } & (\mathrm{S}) & 0,0043 \\ \text { Cromo } & (\mathrm{Cr}) & 25,81 \\ \text { Níquel } & (\mathrm{Ni}) & 6,42 \\ \text { Molibdênio } & (\mathrm{Mo}) & 3,93 \\ \text { Aluminio } & (\mathrm{Al}) & 0,014 \\ \text { Cobre } & (\mathrm{Cu}) & 0,148 \\ \text { Cobalto } & (\mathrm{Co}) & 0,080 \\ \text { Titânio } & (\mathrm{Ti}) & <0,0010 \\ \text { Nióbio } & (\mathrm{Nb}) & <0,0040 \\ \text { Vanádio } & (\mathrm{V}) & 0,076 \\ \text { Tungstênio } & (\mathrm{W}) & 0,055 \\ \text { Chumbo } & (\mathrm{Pb}) & <0,0030 \\ \text { Boro } & (\mathrm{B}) & 0,0020 \\ \text { Estanho } & (\mathrm{Sn}) & <0,0010 \\ \text { Arsênio } & (\mathrm{As}) & 0,0098 \\ \text { Bismuto } & (\mathrm{Bi}) & <0,0015 \\ \text { Cálcio } & (\mathrm{Ca}) & 0,0023 \\ \text { Ferro } & (\mathrm{Fe}) & 62,6 \\ \text { Nitrogênio } & (\mathrm{N}) & 0,25\end{array}$

Procedimento Tork: série P-300.

Normas de Referências: ASTM A 751, ed. 2011.

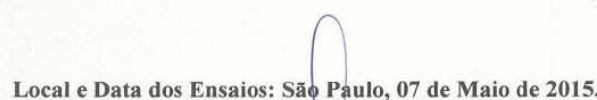

Emissão do relatório: Rio de Janeiro, 13 de Maio de 2015.

Maria Ceciliamendes da Silva

Gerente Técnico de I aboratório

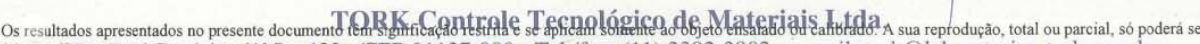

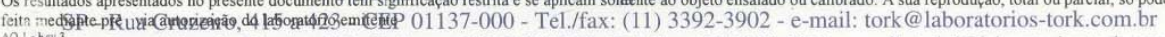

${ }^{A 21}{ }^{k} \mathrm{RJ}^{23}$ - Rua Leopoldino de Oliveira, 392 - Turiaçu - CEP 21360-060 - Tel./Fax: (21) 3830-0011 - e-mail: torkrj@laboratorios-tork.com.br BF 
Re-teste da análise química do aço inoxidável super duplex UNS S32750 (2507).

\section{TORK}

Empresa interessada : PONTIFÍCIA UNIVERSIDADE CATÓLICA DO RIO DE JANEIRO

Rua Marquês de São Vicente, ${ }^{\circ} 225$ - Gávea - Rio de Janeiro / RJ

Pedido de ensaio $\quad: 279671$

Natureza do trabalho : ANÁLISE QUíMICA.

Indicaçoes fornecidas pelo interessado sobre o material ensaiado:

QUANTIDADE........................: 01 Amostra para analise quimica.

IDENTIFICAÇÃO 2507

RESULTADOS OBTIDOS COMPOSIÇÃO QUIMICA (\%)

\begin{tabular}{|c|c|c|}
\hline Carbono & (C) & 0,038 \\
\hline Silício & (Si) & 0.277 \\
\hline Manganês & (Mn) & 0,54 \\
\hline Fósforo & (P) & 0,025 \\
\hline Enxofre & (S) & 0,0048 \\
\hline Cromo & (Cr) & 25.69 \\
\hline Niquel & (Ni) & 6,55 \\
\hline Molibdênio & (Mo) & 3,79 \\
\hline Aluminio & (Al) & 0,016 \\
\hline Cobre & $(\mathrm{Cu})$ & 0,152 \\
\hline Cobalto & (Co) & 0,083 \\
\hline Titânio & (Ti) & $<0,0010$ \\
\hline Nióbio & $(\mathrm{Nb})$ & 0,012 \\
\hline Vanádio & (V) & 0,068 \\
\hline Tungstênio & (W) & 0,057 \\
\hline Chumbo & $(\mathrm{Pb})$ & $<0,0030$ \\
\hline Boro & (B) & 0,0023 \\
\hline Estanho & (Sn) & $<0,0010$ \\
\hline Arsênio & (As) & 0,0028 \\
\hline Bismuto & (Bi) & $<0,0015$ \\
\hline Cálcio & (Ca) & 0,0021 \\
\hline Ferro & (Fe) & 62,7 \\
\hline Nitrogênio & $(\mathrm{N})$ & 0.22 \\
\hline
\end{tabular}

Procedimento Tork: série P-300.

Normas de Referências: ASTM A 751, ed. 2011.

Local e Data dos Ensaios: São Paulo, 24 de Setembro de 2015. Emissão do relatório: Rio de Janeiro, 25 de Setembro de 2015. 